\title{
(x)
}

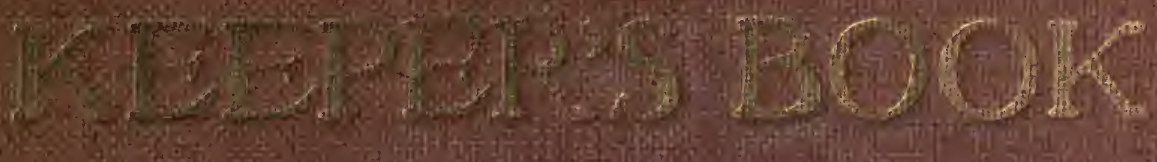

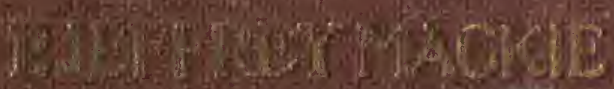

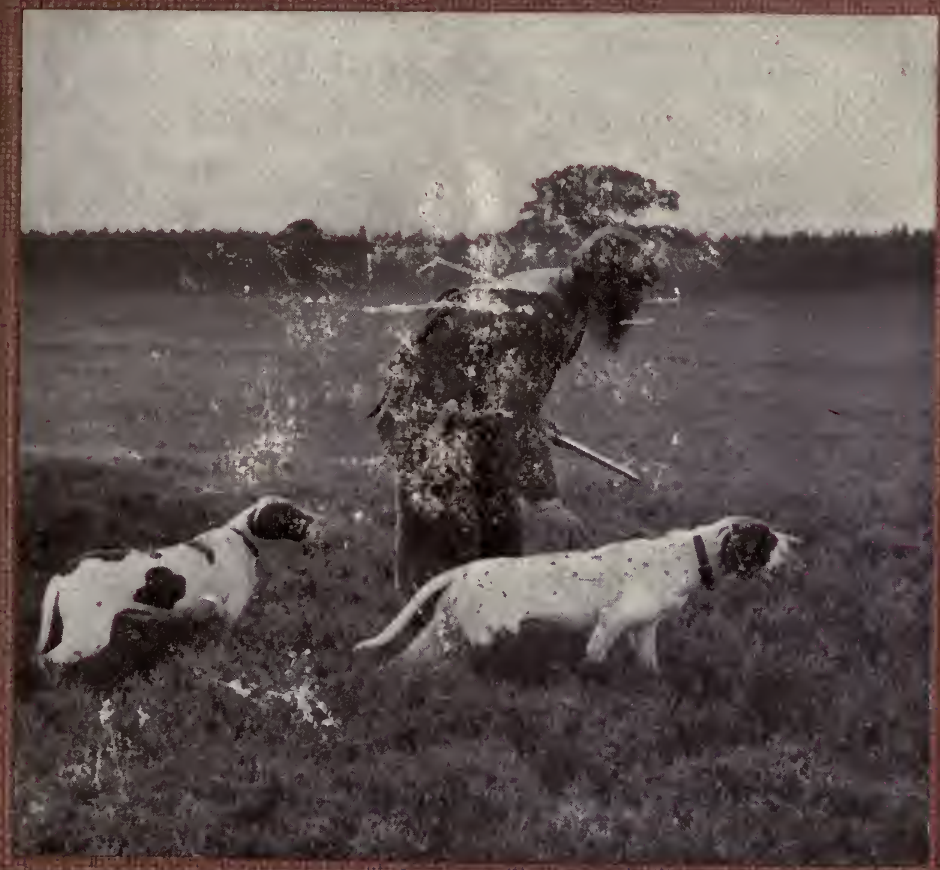

$\frac{0}{3}$
2
0

SEVENTH EDITION 


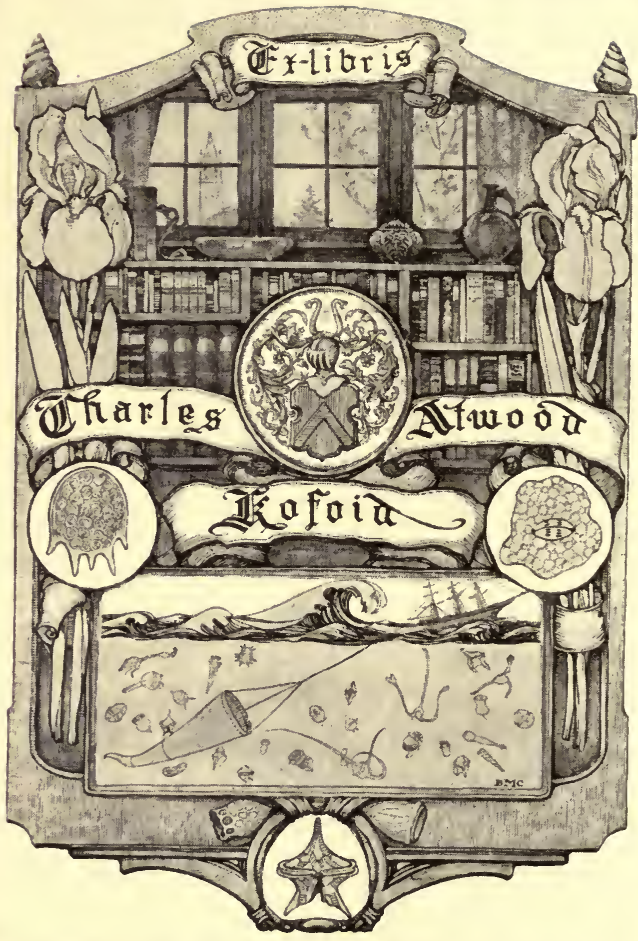




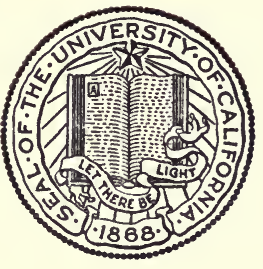

THE LIBRARY OF THE UNIVERSITY OF CALIFORNIA

PRESENTED BY

PROF. CHARLES A. KOFOID AND MRS. PRUDENCE W. KOFOID 



THE KEEPER'S BOOK 
First Impression, January 1904

Reprint, February roo4

Reprint, April 1904

Revised and Enlarged, August 1906

Reprint, August 1906

Reprint, June 1909

Enlarged and Rewritten, August 1910 

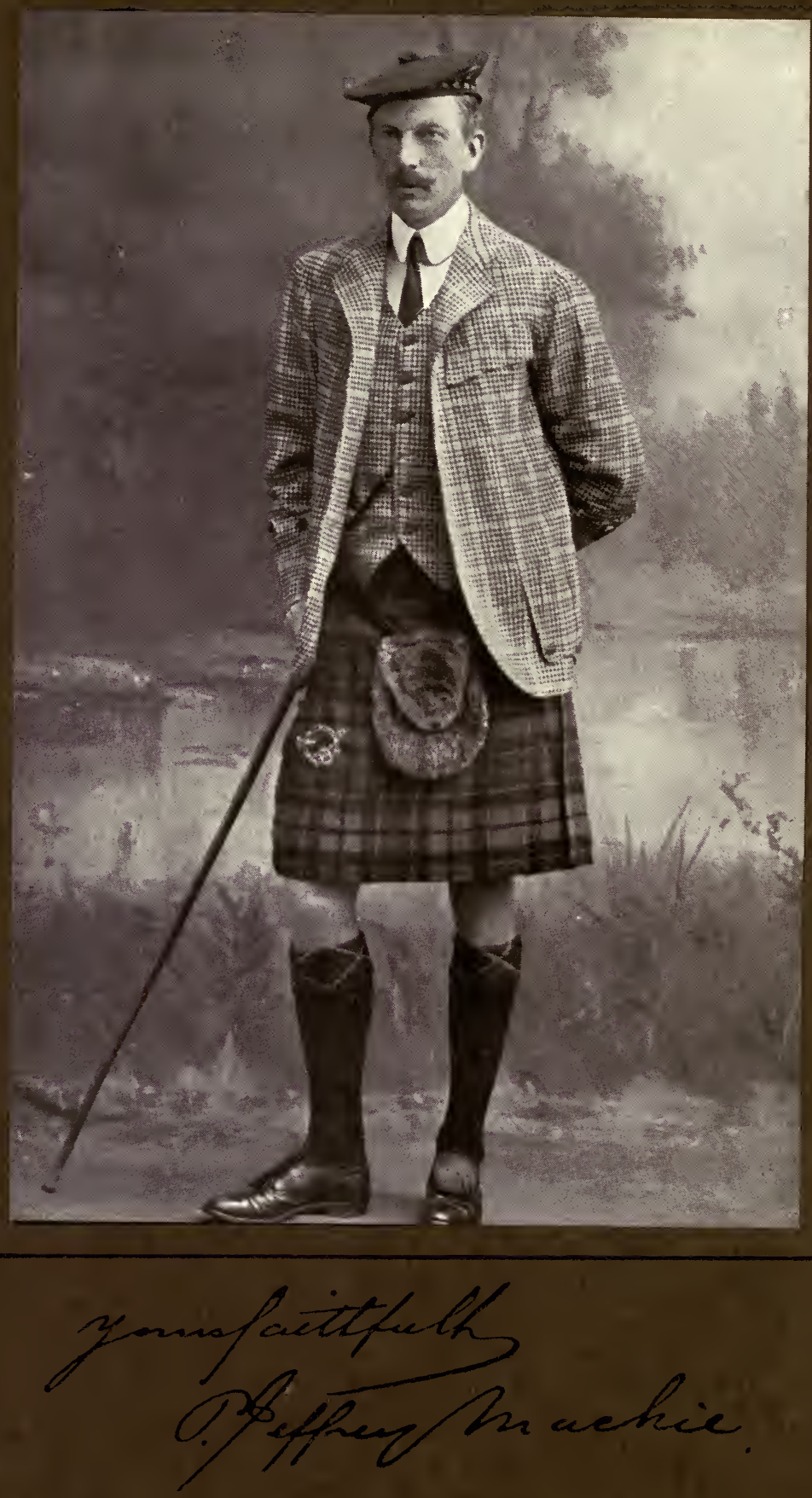


\title{
THE KEEPER'S BOOK
}

A GUIDE TO

THE DUTIES OF A GAMEKEEPER

\author{
SEVENTH EDITION \\ REWRITTEN AND ENLARGED \\ BY \\ P. JEFFREY MACKIE \\ aUthoR OF "EMPIRE" ETC. ETC.
}

WITH SPECIAL CHAPTERS BY

LORD MALISE GRAHAM, CAPTAIN H. SHAW KENNEDY DR. CHARLES REID, H. BURN-MURDOCH, ADVOCATE P. D. MALLOCH, F. G. AFLALO, HENRY LAMOND TOM SPEEDY, AND OTHERS

T. N. FOULIS 2I PATERNOSTER SQUARE, LONDON I5 FREDERICK STREET, EDINBURGH I 9 IO 

THIS SEVENTH EDITION

Is

DEDICATED

TO THE

BOYS OF SCOTLAND 



\section{PREFACE TO THE SEVENTH EDITION}

The issue of the Seventh Edition, revised, rewritten, and enlarged by several new articles, is gratifying proof that the interest in sport still continues, notwithstanding the changed times in which we live.

Originally intended for gamekeepers, it must be confessed the success of the book is not due to their patronage; indeed, excepting in the case of a few, it has, I fear, incurred the displeasure of the whole profession. The average Scotch gamekeeper dislikes books, and thinks that he has nothing to learn from them, and although many masters have bought the book, and made a present of it to their keepers, and in many instances placed it on the Bothy Library, it has not evoked any enthusiasm. My outspoken language, about which there can be no mistake, has in many cases given great offence, but, much as I regret this, I have nothing to withdraw or retract. On the subject of Game Preserving much has been learned since the issue of the First Edition, and opinions have changed on 
many subjects, necessitating the rewriting of the book. Nothing stands still nowadays except stupidity.

A demand has sprung up for The Keeper's Book which was not anticipated: to a considerable extent it is being read by schoolboys and the youth of the country. To be a thorough sportsman you must start young; but if you are to be master of your own shoot, you must also be well grounded in the rudiments and spadework of gamekeeping, otherwise you will be imposed upon, as so many are at present. Every boy, before he is allowed to shoot in company, should have a thorough knowledge of the art of driving, beating, stopping, and the whole science of the game. He should also know natural history, and habits of all game and vermin. This knowledge can best be acquired by practical experience, and with his superior education and powers of observation a boy will soon acquire a love of the study of game-preserving, which to the workingman may merely be a duty and means of livelihood. Boys should be encouraged to accompany the keeper on his rounds; much information may be thereby gained.

It is a pity that the tendency of the people is to flock to the towns, and that our school teaching is not more practical. The main object of our system of National Education should be to prepare mankind for the work which they intend to perform in the world. Children intended for a country life should be taught natural history, agriculture, the origin and the use of 
the objects which they see in their everyday surroundings. An interest and love of rural affairs would thus be engendered, and they would be more content to live in the country. In towns, good technical schools ought to be provided for the paid workers as well as for the employers. The capitalist plays a great part in the world, but he might still play a greater part if he were trained in the potentialities of the business to which he intends to devote himself.

At present, country children are educated to townward ambitions, and town children to ambitions and aspirations, far above their capabilities, except in isolated cases of specially strong individualities.

Many of the absurd prejudices which we Britons have hugged for years are fast disappearing. None is more noticeable in this respect than the position assumed by many landed proprietors, that to know anything of, or to be in business, was not compatible with being a gentleman; but to them sport was everything. The effects have been disastrous. Many of the professions have tried the same game and failed. It is only now dawning upon many that work is no degradation; this is being forced on us by our trade rivals the Americans and Germans, who have been gaining ground on us while we have been playing, and who look upon our silly standard of form, with silent pity and contempt. Let us be logical : we cannot live without money, and the only way to make it nowadays is to work for it; and the harder we work, the more 
need there is for recreation and sport. Therefore, for the future, it looks as if sport is to be for the workers, and not for the idlers.

Let the younger generation get rid of the idea that work is infra dig., or bad form; the true criterion of a gentleman should be his conduct and character-not his trade or profession. Britain is still whole at heart, and our Empire is only yet in its infancy. We are now awake, and there are vast fields of enterprise for honest workers undeveloped. The lazy, dishonest doctrine of the Socialist-that robbing the rich will make the poor richer-has no hold on the educated sane thinkers of the country. Success in anything requires self-reliance, energy, and thrift, and if our youth, whether in sport or business, cultivate these virtues and maintain a high standard of honour, there is little fear of Britain degenerating into a nation of State-fed paupers-which is the logical conclusion of the Socialist's doctrine.

I acknowledge my indebtedness to the many sportsmen who have received the book so kindly, and while differences of opinion exist on many of the theories, yet this is so on all subjects. I have no wish to escape criticism ; the object of the book is to encourage investigation and draw out the experience of others. There are several new articles which should prove of interest. $\mathrm{I}$ am very much indebted to my friend $\mathrm{F}$. G. Aflalo, with whom I fished for sharks while on a journey to Australia some years ago; I commend his articles on deep-sea fishing, on which he is an experienced 
and much-esteemed writer. There is no doubt that sea fishing is much neglected, though there can be got from it much sport with little trouble, while it will furnish very often, a pleasant change to a houseful of guests, and give a rest to the moor and fresh-water loch.

Another new chapter is that of Fish Hatching, by Mr. Henry Lamond, Secretary of the Loch Lomond Fishing Association. A hatchery is a necessity on all rivers where a sufficient stock of fish is to be maintained. The most economical way to stock waters is by a small hatchery, and much could be done by this means, especially in the Highlands, where the waters are too often neglected. The formation of Fishing Clubs, with small bungalows where members could stay a few days, would form pleasant retreats from the busy world. It is surprising that more of these do not exist in Scotland. Canada and America are more practical, and have many of these small clubs.

We are yearly increasing our knowledge on the subject of salmon, and such questions which periodically crop up in the sporting papers, as "Do salmon feed in fresh water?" "Do adders swallow their young?" etc. etc., will soon be settled points. Mr. Malloch's most excellent book, just published, on the History and Habits of the Salmon, Sea Trout, and other FreshWater Fish should be read by all fishermen. $\mathrm{He}$ has added much to our knowledge of the fish tribe.

My suggestion in the Preface of the last edition regarding an inquiry into the grouse disease has 
borne no fruit. From The Field, however, the writer notices that Dr. A. E. Shipley has made some interesting discoveries regarding the external and internal parasites of the grouse. (See chapter on Diseases of Game.)

The article on Dogs by the late Dr. Charles Reid remains the same. I cannot improve it, and since the last edition was written this gentle and charming companion has gone to the great Unknown Land. No one who knew him in his football days, with his big, burly figure, would have thought that he would be taken so soon. He was one of the most gentle and lovable of men.

The Scottish Retriever Trials Association is worthy of more support than it receives, and although good retrievers are more numerous than they were, they are still too scarce. Sir Mitchell Thomson as President of this Society has done much to stimulate keepers giving more attention to this indispensable dog.

Forestry is attracting more attention in Scotland, and an Association of Proprietors has been formed to engage an expert who will advise the foresters of those proprietors who are members of the Association. The Association supplies a want, and we are indebted to the Laird of Largie for its inception. While we in this country are behind the Germans in Planting, Sylviculture, and Forestry, it is questionable, owing to the long wait for returns, whether planting in quantity will 
ever become popular in Great Britain, or if it can ever employ a great number of men. That planting increases fertility of the soil, and is necessary for shelter, there can be no doubt. Most proprietors, if only for game shelter purposes, should encourage planting on their properties, and should assist the movement by joining the Landowners' Co-operation, of which John D. Sutherland, factor, Oban, is secretary. The annual subscription is two guineas.

I am unwilling to refer to politics in a book which deals entirely with sport, but in these socialistic times, when the State dominates our existence, curtails our liberties, and makes us mere slaves, cannot refrain from expressing how necessary it is that landowners and others interested in sport should take a sensible view, and interest themselves in local affairs, and thus create a better understanding with their neighbours. This will help to remove the present bad feeling.

Landowners are surprised at the socialistic ideas expressed by the people, and the unfair attitude shown towards property; but they have themselves to blame; and the views held by the people, whether real or assumed, have grown owing to the neglect of the landowning class. Much of the discontent in the country arises from the poor condition existing in agriculture, and low prices, resulting from the free importation of foreign produce. Country people not understanding this, and townspeople looking to their own in- 
terests for cheap food, blame the landlords and the land laws, and raise the shout, "The Land for the People." The real remedy is Tariff Reform. It is manifestly unfair that agriculturalists paying high taxation should be exposed to the competition of foreign imports, which pay no rates and taxes. Proprietors and others would help greatly to remedy this unfortunate state of matters if they would take some trouble to encourage co-operation and better organisation for the disposal and sale of Home Produce. The encouragement of the Scottish Agricultural Organisation Society Ltd., 5 St. Andrew Square, Edinburgh, is doing good work in fostering the erection of bacon factories, co-operative dairying and egg societies, all of which go to encourage thrift and method with business habits amongst the peasantry and farmers, and at the same time find better sale for their produce. With the advent of Tariff Reform would come the opening of flour mills now long silent, which would supply cheaper offal and stuffs for the feeding and fattening of cattle and pigs in this country. It will be seen, therefore, that it is to the advantage of proprietors and large farmers, as well as others interested in agriculture, to encourage these objects with the view to bringing back to the country contentment and renewed prosperity.

It cannot be said that land is over-rented ; few investments show so poor a return as land, and one is infinitely better with his money in Consols, being saved 
all worry and responsibility. In taking the returns for the County of Argyll, it will be found that the rental of agricultural land in $1906-07$ as compared with I 876-77 is reduced from $£ 302{ }^{\circ} 763$ to $£ 168 \cdot 760$, showing a loss of $\AA_{1} 34^{\circ} 003$, leaving only $55^{\circ} 74$ per cent. of the rental of 1876 , or a loss of 44.22 per cent. This is very serious, and is entirely due to our bad business system of free imports. The capital loss at twentyfive years' purchase is $£ 3340^{\circ} 325$ : at twenty years' purchase, $£ 2672 \cdot 260$. Then rates have all increased. Poor, Sanitary, Road, and County in 1855 amounted to $£_{3.345}$; in 1905 , including school rates, they amounted to $£ 77,000$, or an increase of 245 per cent. over those imposed in 1855 : surely land is no monopoly, nor is over-rented.

To the boys of Scotland, to whom this volume is dedicated, I would finally say, you are the trustees of posterity. Tariff Reform in a nut-shell is summed up in $\Varangle$ the following unanswerable arguments :-

Production is the primary source of wealth.

The home producer pays local and Imperial taxation, averaging from Io to 15 per cent. on his produce.

Imports from abroad pay us no taxation. There can be therefore no protection to the home producer till foreign imports pay the same rates of taxation for the use of the market as the home producer pays.

At present the foreigner has the protection in this $b$ 
country, not the home producer, and in justice this state of affairs should be remedied, and the home producer put on an equal footing with the foreigner-that is all we ask.

Why does the present fiscal system exist? selfishness, greed. The townspeople want cheap food, even if it is at the expense of the county population, and they are backed up by large chemical, cocoa, and other employers who want cheap labour; also subsidised by money from foreigners who are naturally anxious not to lose the only free market they have abroad wherein to dump their surplus goods.

The evils that ensue are depopulation of county districts, degeneracy of the race, overcrowding of cities, need of emigration of our finest blood and sinew, etc. etc., and for all these evils, the Free Traders offer sham remedies, anything but the real one, because it affects their pockets. Any saving in the cost of food by the many, is more than counterbalanced by the loss of work and wastage to the nation, and which must be made up by extra taxation in other ways; it is six and half a dozen. The following extracts from the Daily Mail are worthy of consideration and adoption :-

"The administration of public finance nowadays is a science and a business. It calls for trained administrators who will devote not only their whole time to it but their whole energy and skill. They should have no political entanglements, and least of all any electioneer- 
ing crazes. A non-political Budget, prepared and explained by fiscal experts, would be a welcome change from the parliamentary muddling of the past twelve months. A very brief experience of it would make people wonder how they could ever have left the finances of the Empire at the mercy of voluble talkers without a shred of practical experience. If they are to be: saved from increasing chaos they will have at no distant date to be put under proper guardianship. And if the taxpayer is to be delivered from the tyranny of ignorant and inconsiderate taxation he must have an appeal from official caprice to independent and impartial tribunals."

\section{TAKING THE BUDGET OUT OF POLITICS}

"In short, it might in due time deliver our financial and fiscal policies from political amateurs and put them in charge of trained administrators. This is an ideal toward which the principal nations of the world are half-consciously advancing. To take the Budget and the tariff out of politics altogether is now the common aim of German, French, and American statesmen. Previous to Mr. Lloyd George's time that idea had not taken shape in this country, but his Budget of 1909 has given it a great fillip. Business finance has got to come. Taxation to the tune of 150 or 160 millions sterling a year cannot go on much longer as a political game, taking its chance among the ups and downs of 



\section{L L U S T R A T I O N S}

From Photographs by

CHARLES REID, WISHAW.

P. JefFrey MACkie, EsQ. (from a Photograph) . • Frontispiece

A PoAcher . . . . . . . . Facing page 36

Glenreasdell Kennels-

\begin{tabular}{|c|c|c|c|c|c|c|c|}
\hline Plan & . & . & . & . & . & . & Page 98 \\
\hline Front Elevation & • & • & 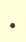 & - & - & & , 99 \\
\hline Cross Section & & • & . & . & . & • & , 10 \\
\hline
\end{tabular}

Vieivs of Keeper's House and Kennels at Glenreas-

Dell, ARgyllshire . . . . . . Facing page 100

The Hunter's Friend and the Keeper's Foe • • , 108

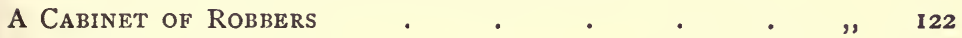

WAITING FOR THE GUNS . . . . . . $\quad$, 152

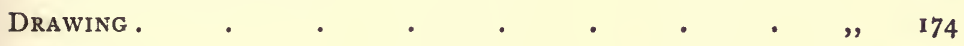

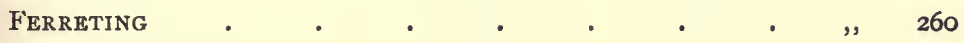

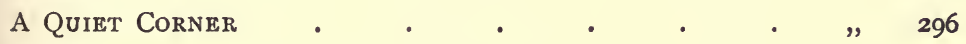

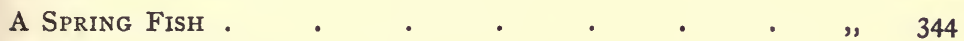

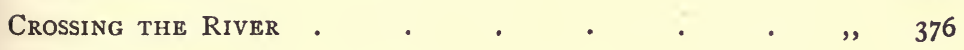

LUSS HATCHERY -

Plan Showing Arrangement of Hatching Boxes and Water Supply ${ }_{\mathrm{xxi}} \cdot{ }^{\circ}$. Page 420 



\section{THE KEEPER'S BOOK}

\section{CHAPTER I}

\section{INTRODUCTION}

Some years ago one of the writers visited a school in the West Highlands, and having listened for some time to a cross-examination of one of the senior classes in history, he expressed a desire to present a prize to the boy who showed the best powers of observation and definition in description thereof. Amongst the questions addressed to the class was the one, "What is a gamekeeper ? " and an answer he received from a bright-eyed, sandy-haired Celt of about ten years of age was, "A big man who goes about in a braw suit of tweeds, wi' a dog and a gun and does naethin'." Now, though out of the mouths of babes and sucklings we are apt to perfect wisdom, we must not, of course, attempt tojustify humour at the expense of justice. The little Highlander's answer was very much on the line of the street boy's definition of a Club as "A house where gentlemen read newspapers on Sunday," although there is more of real truth in the 
latter than in the former reply. Both, however, indicate a real impression that had been made upon two fairly observant youngsters, and neither reply is to be despised as an unsuitable subject for reflection.

It must be admitted that there are many keepers whose chief occupation up till the I 2 th of August, or even till the Ist of September or the Ist of October, seems to consist in going about with a dog and a gun and in virtually doing nothing - that is, nothing of real value to the shooting under their control. In no other class of men do we find such extremes, on the one hand of skill, energy, and efficiency, and on the other of stupidity, laziness, and incapability. Taking the profession as a whole, and regarding it as a department of skilled labour, we must admit, though in doing so the admission gives offence, that it does not in the main reach the uniform efficiency of other skilled labour.

The fact that an outstanding minority of keepers are more than efficient, and combine the qualities of patient and intelligent keepers of ground and stock with all the instincts and capacities of thorough sportsmen, does not get rid of the truth of the general criticism. Of course no one would insult the profession of gamekeeping by placing it in the same category with any branch of unskilled labour in the industrial community. It is because we believe the duties of a keeper demand a high standard of observation, skill, patience, and energy, that we have to admit the failure, in the common run of the profession, to 
reach that standard. Viewing them on the moral side alone, we are only too willing to recognise that for probity and general temperance gamekeepers compare favourably with any other section of society. In fifty per cent. of cases they are sober, honest, good-tempered, and naturally generous, and to all these qualities they add, as a rule, an exceptionally keen sense of humour. But, considering the responsibilities of their profession, the percentage of efficient and trustworthy workmen is infinitely smaller than the figure quoted above.

This book is written for "all good keepers who know their work, and for the indifferent ones who do not." How competent a person, as a rule, is the good keeper who knows! He is not only a grand sportsman, but a splendid servant-a man who knows nearly everything that is to be learnt of the habits and habitats of game, and of the necessary methods to manage and improve the ground, stock, and shootings under his care, and yet is always on the outlook to learn more. The really first-class keeper is a precious jewel in the crown of sport-a man who often puts to shame the knowledge and skill of a well-read and keenly observant master, and this capable servant is the man of all others who deplores the fact that the status of his profession is lowered by men with the sporting knowledge of farm labourers, the energy of vagabond hucksters, the initiative of village loons-and who are thoroughly convinced that they know everything.

It has been said that the ideal keeper combines 
skill with energy, but even in good keepers the combination is rare. An ideal keeper, in our view, would combine the sporting capacities of the Highlander with the energy and perseverance of the Lowlander. The first has probably more insight and general intelligence, the latter more initiative and energy. As Mr. Stuart Wortley has so aptly said: "Highlanders are, as all the world knows, a very fine race of men, courageous and loyal, courteous and amiable-they make the best sportsmen and the best soldiers in the world; but they are neither so practical nor so energetic under ordinary conditions as the northern Englishman, and laziness is their great failing."

The fact of the matter is that the Highlander is a born hunter, and the descendant of a long line of hunters. His ancestors having been brought up under the clan system, "blue" blood runs in his veins, and his instincts are still strong for fighting and hunting, not for butt-building and draining. $\mathrm{He}$ is a lineal descendant of men of the type of Maclean of Ardgour, "strong Donald the hunter, Macgillean Mohr."

Low down by yon burn that's half-hidden with heather, He lurked like a lion, in the lair he knew well,

'Twas there sobbed the red-deer to feel his keen dagger, There pierced by his arrow, the cailzie cock fell.

How oft when at e'en he would watch for the wild fowl, Like lightning his coracle sped from the shore;

But still, and for, aye, as we cross the lone Lochan,

Is Donald the hunter Macgillean Mohr.

Time and circumstances of civilisation have done much to modify the Highland spirits and instincts, but 
the independence, pride, and tradition, which make a Highlander naturally antagonistic to that manual labour which is a necessary accompaniment of a gamekeeper's duties, still remain to a marked extent, especially amongst the keepers of the Western Highlands and Islands. Let one of these latter have a gun or rod in his hand, or let him be spying out your deer in the forest or tracking your birds on the moor, and there is no man in the world to compare with him ; but put him to drain your water-soaked ground, repair or rebuild your butts, or to do any of the innumerable prosaic duties inseparable from a gamekeeper's responsibilities, and he is not to be compared either with the Yorkshire or Norfolk keeper, nor with the man from the Lothians.

The pride and exigencies of race, which have confined the Highlander's instincts to hunting and fighting, also assert themselves in a marked way in his relations to his master. If the latter is "the laird," one of a line of fifty Campbells, a hundred Mackintoshes, or a thousand Grants, then the Highlander is a much more satisfactory workman than if his master is a "Sassenach," or comes of a branch of whom he still virtually regards as an alien people. In the former case he is one of a family, in the latter he has an instinctive feeling of resentment in being reduced to a position of mere servitude. $\mathrm{He}$ is slow to come into touch with modern social conditions.

But though these reflections may be allowable, it is dangerous to generalise more, and while admitting the 
marked distinctions between Highlander and Lowlander, it would be idle to shoot their characters into separate pigeonholes. We have in our mind many Highland keepers, who combined keen sporting instincts and capacities with indomitable energy and perseverance in the pursuit of their more irksome duties; and we also recall many Lowlanders and English shire keepers who were preternaturally lazy.

It is to be regretted that the qualities of charm and laziness so often go together. Some of the most interesting keepers we have known have been the most indolent. We remember one particular keeper in Perthshire, whose knowledge of sport and whose facility for narrative made of him a fascinating companion in the chase, yet who invariably neglected such duties as the killing of vermin, the digging out of springs, the proper burning of heather, and the hundred little duties for which more especially he was paid. Of course he knew all about the rights and wrongs of these matters, but, in dealing with these questions, he spoke in the vaguest generalities, and rapidly turned the conversation to some famous day on the hill when late in the season "the Captain," his master, killed forty brace to his own gun, or to a story of some record stalk in the forests of Ross-shire or Aberdeenshire. 'There was not an experience of our own that he could not cap with a story of brilliant shooting on his old master's part, and equally skilful manœuvring on his own, and his exploits were all told with such a power of pictur- 
esque description that any criticism of his constant disregard of the moor and stock improvement was disarmed. The net result of this keeper's inequalities has been a sad deterioration of the shooting capacities of the moor which was under his control-a deterioration, which it will take many years for a new, and probably more reticent, keeper to correct. The particular moor in question is loaded with vermin, the heather is long and rank, the springs are clogged with undergrowth, and a thousand-acred shooting now realises about ten brace of grouse a year. In our younger days, before we began to understand the science of maintaining a moor as breeding ground for grouse, we considered this old keeper infallible. He could cast a better line than any man we met: he seemed to know the actual capacity of every fly. We can vouch to the brilliance of his shooting, to his knowledge of the habits and haunts of birds, and to his skill in leading his master through the intricacies of the most difficult stalk, and it is sad that we have now to dethrone him from the pedestal on which we had placed him, when we view in cold blood the inefficiencies of his character as a responsible keeper.

Let it be frankly admitted that the responsibility for the prevalence of inefficiency lies, to a great extent, at the door of the owners or occupiers of the shootings. There has been and there is too little recognition of the services of good keepers. There is not sufficient sliding in the scale of wages to urge on the keeper in general 
to improve his knowledge and his capacity for work. Remuneration for labour is conducted on all too stereotyped lines: the efficient keeper is generally paid the same wage as the inefficient. There is too little recognition of superiority and too little condemnation of the reverse; and this being the case, the result is obvious. The keeper has little stimulus to improvement, outside his own personal self-respect, and in consequence the standard of general efficiency is kept lower than it should be.

Much of the inefficiency of the keeper is also due to the ignorance or indifference of the master. Want of supervision from either of these causes is certain to lead to slackness, and this is bound to lead also to deterioration of sport. But it must be pointed out that, if the ignorance or carelessness of a master may account for a keeper's slackness and inefficiency, it does not excuse it. Even taking the master on the highest plane, he can seldom be more than a very good amateur. The keeper is, or ought to be, a specialist. Within the limits of his duties, a keeper should know all that is to be known, and, in the majority of cases, should know infinitely more than his master. Not only should he be independent of any chance instruction from his employer, but he should be in the position when called upon to do so, to give advice and convey information at all points. In fact, the highest state of perfection can only be reached if a keeper bases his knowledge and his work on the possibility of his master being an absolute 
ignoramus on all matters, not even excepting the handling of a gun.

The relationship between master and keeper varies largely on all shootings. In some cases the former takes little or no concern with the details connected with the improvement and management of his ground and stock, and is only concerned with the sport of the days on which he or his friends may shoot. In other cases the master assumes the direction of, and dictation on, all matters affecting his sport, and requires that his keeper should make him conversant with every step he takes in the pursuit of his calling.

Between these two extremes are found masters, whose interest and attention are keen on some, and indifferent on other points. It is chiefly in dealing with the latter cases that the keeper will have to use any discretion and tact he possesses, discerning when and where he is expected to seek or give advice, and when and where this is not required of him. In those cases where the masters virtually assume the whole control of the details connected with their shootings, it is often found that, with a desire to please-especially common amongst the courteous Highlanders-keepers often hold back any definite knowledge they possess and views they hold which ought to be of infinite value to the master. The intelligent and responsible keeper can always give information, or make suggestions, without being dogmatic, and he is but a poor gamekeeper who hides his knowledge and his opinions in order to 
be obsequious, or from fear of contradiction. Civilly, quietly, yet firmly he should state his facts and express his views, and he will find that he is seldom misunderstood and always respected. The man who prevaricates for the sake of pleasing, who pretends to know when he is ignorant, or pretends to be ignorant when he knows, is a bad servant, and is sure in the long-run to get into difficulties.

It will be gathered from what we have already said that we are dealing with the keeper as a skilled specialist. We have not much to say as to that anomaly -the occasional keeper. We mean the man who is really not a gamekeeper at all, but a farm hand who goes out with the guns, and who is the only person in charge of the shooting. To attempt to instruct such a person would be a waste of energy and a dissipation of good sense. Such a man may learn a little but he has neither the time nor the instincts for sport. And yet how many of our so-called keepers are but mere labourers? They might possibly know the difference between a grouse and a grey hen, but as to the habits and habitats of game, as to the destructive capacity of vermin, as to the tempers and temperaments of dogs, they are as ignorant as the sedentary Cockney, whose only knowledge of game has been obtained at the "Jungle" at Earl's Court. 


\section{NOTES}




\section{NOTES}




\section{CHAPTER II}

\section{The Ideal Keeper}

What has been written will enable the reader to picture the main lines upon which the good keeper may be constructed. Much will depend on the man's character, on his sense of responsibility, his sense of duty, his ambitions, his perseverance and persistence under difficulties, his determination to succeed in a career that has a history behind it of honour and fame. No man ever did much in this world who started in life with the resolution only to be as competent as his fellows. It is well to have the ambition to be better. The history of general progress is the story of personal endeavour. This is no doubt a truism, an oft-repeated commonplace, but commonplaces after all are the most neglected things in our modern world of superior beings. If a keeper would only make up his mind that, in addition to the careful carrying out of his duties, he would add one single fact to our practical knowledge of the science of sport, he would have done no little thing for that vast army of men who find in this form of recreation the best way to attain to the mens sana in corpore sano. 
There are so many tantalising curbs on human endeavour that it is difficult to reach perfection. However, it is good for us to have practical ideals-signposts which point to success-even although we find in the long-run that our reach far exceeds our grasp. One thing is certain, that the good keeper seldom stands still, he never stagnates; his knowledge and his capacity ripen with the years. How many keepers there are who never seem to improve, who gradually forget all they have learned, and become impervious to new ideas, and add to this mental deterioration the slow disease of indolence. The average gamekeeper is the most conservative man on earth. Not only does he nourish the long-practised methods of the shooting on which he is trained, but he is impatient of any suggestion that might interfere with his own settled convictions. Even the best of keepers is apt to be solid, stable, and stationary. As has been said of the oldfashioned Tory in politics : "Firmly rooted in the past, he draws his nourishment from the traditions of his fathers, submits himself willingly to the constituted authorities of the present, the heritage of the past, and finds his proper field of action in the administration of things as they are. His disadvantage lies in his blindness to the future, and in his systematic ignoring of the principles of change and progress in the universe. When all things are moving around him, from his want of adaptability to new circumstances, he is at last forced to accept un- 
graciously changes which it would have been his wisdom to anticipate."

On the whole, it must be admitted that very little has been learned in regard to sport that was not known by our progenitors as to the habits and habitats of game, but much has been discovered as to their care and preservation, and more as to the best ways of bringing game to the gun; and it is in dealing with these latter problems that the keeper should show himself amenable to ideas and try to keep in touch with the newest views and profit by them,- - not by blindly accepting each new theory as gospel, but by testing it carefully by the light of his own experience-in other words, by giving it a fair trial. One has only to use one's eyes to observe how the old-fashioned and discredited practices of the past are still followed on some of our best shootings. The prehistoric butts on the skyline, the indiscriminate burning of heather, the smoking out of rabbits, the bands of yelling beaters advancing in a straight line to the guns-all remain as persistent monuments to the conservatism of the keeper, despite all that comes to his ears of greater success achieved under newer methods. As far as some keepers and their masters are concerned, Lord Walsingham, Sir R. Payne Gallwey, Mr. Stuart Wortley, Mr. Lloyd Price, Mr. Harting, Mr. Tom Speedy, and The Mackintosh of Mackintosh might never have made an experiment nor written a word. They seem to forget that sport is not a form of theology, final and irrevocable, but a branch of 
science, varying under the exigencies of sense and experience.

The mention of certain famed authorities on matters of sport leads us to observe how little advantage has been taken of the literature of sport by the gamekeeper class. No doubt the keen and intelligent master puts his keepers in possession of the ideas he has accumulated from books, but this is not in itself an absolutely satisfactory state of affairs. Keepers should be encouraged to read for themselves; in some cases to correct their own opinions, and in others to add to their own extensive knowledge. Many keepers are apt to despise books on sport as the writings of mere theorists, and to shun them accordingly. It would be as well for them to understand that this is an error of the first magnitude. Nothing is more fortunate for sport than that its literature emanates from some of its most practical exponents, and it was this very fact that deterred the present writers, for a time, from going to press with the present volume, for up till now there has been no valuable work on sport that has not been written by a great sportsman. An analogous remark cannot be made of other branches of literature, and this fact should upset the prejudice amongst keepers against that which they regard as mere book learning. It will be found that most masters are only too delighted to lend to their keepers such books as the volumes of the Fur, Feather, and Fin series, the volumes of the Badminton Library dealing with shooting, the Encyclopadia of Sport, and 
the contributions of Mr. Speedy, Mr. John Colquhoun, Mr. Hutchinson, Mr. Bromley Davenport, Sir E. Grey, Mr. Innes Shand, Mr. Lloyd Price, Mr. Harting, Mr. Carnegie, and others. In fact, it is the master's duty to see that his keeper is put in possession-temporarily, it may be-of some of the more practical of these writings, and to insist that advantage be taken of the advice there put forward.

Not that all the knowledge of sport is to be found in the brains of the writers of books. There are skilful arts practised by some of our best keepers that have never yet been put down in black and white. There are many "tricks of the trade" that are still sacred to particular shootings. For sport, in its widest sense, as embracing the preservation of game, is, like shooting, not only a science-it is an art. A man may know much about law without being a great lawyer; a man may be conversant with most of the facts of medical science, and yet be a poor physician. An analogous remark applies to the profession of gamekeeping to such an extent that a keeper, like a poacher, is supposed to be "born," not "made." But a belief in this fact often leads to the most disastrous results. The men who are thoroughly convinced in their own minds that they are heaven-born keepers, are apt to be conceited, opinionative, dogmatic, despotic, and imperious, "given to run riot in idolatries, drifting into vanities, congregating in absurdities, planning shortsightedly, plotting dementedly." They regard with dis- 
dain the suggestions of the man who has learned his business by mere patient plodding. Let even the man who is a sportsman by instinct and a keeper by nature not hesitate to learn of men who are his inferiors, perhaps, in everything except a little knowledge.

Enthusiasm, although it is not everything, is an invaluable quality in the good keeper. It inspires enthusiasm not only in his underlings, but in the sportsmen themselves. Nothing is more depressing to a day's shooting than to have a keeper who seems bored by his work. Such a day is bound to be a failure, or, at best, an imperfect success. The joy of sport; the keenness for a good bag ; the evident and just pride in knowledge which the keeper is only too willing to impart; the calm, firm, and deliberate manner in carrying out a plan, skilfully and patiently constructed-these are the conditions that inspire confidence in and respect from the sportsman. But seeming indifference ; evident ignorance; a noisy, changeful, aimless plan of campaignthese are the conditions that make for the irritation of "the guns" and for a general feeling of dissatisfaction. When the latter conditions exist, it will in all likelihood be found that the courtesy of the keeper is in proportion to the size of his tips and his geniality to the number of his " nips." Such a man is a disgrace to an historical and responsible profession. $\mathrm{He}$ can be of no satisfaction to himself, and is a nuisance to everybody else. He quarrels with the farm servants; he indiscriminately shoots every suspicious dog that he meets; 
he is outwitted by poachers, and is hated by his assistants. Knowledge, skill, perseverance, discrimination, firmness, order, courtesy, and enthusiasm-these are the eight primary necessities for a good keeper. Knowledge of the technicalities of his craft, skill to carry them out, perseverance in face of difficulty and failure, discrimination in dealing with superiors, equals, neighbours, and inferiors, firmness in all he does, order in all his methods-in his books, his kennels, and his sporting arrangements-and enthusiasm to carry out what he has carefully planned, modified by a gracious civility, all these will tend to his own, his master's, and his servants' satisfaction.

Above all things the ideal keeper is humane. His humanity is not only shown by his careful consideration of his fellow-men, but of those faithful servants of the chase-the horse and the dog; and if his humanity is of the right quality he will extend his gentleness and consideration so as to prevent unnecessary suffering to the quarry of the chase. The hunting song says: "Though we all hunt reynard, we love him." In the same way the instinct of love and pity also extends to the birds of the air and the other beasts of the field. A cruel keeper is a monster. 


\section{NOTES}




\section{CHAPTER III}

\section{Relations with Farmers, etc.}

However skilful and energetic a keeper may be, however brilliant his qualifications, or original his ideas, he will find himself considerably handicapped unless he be able to keep at peace with his neighbours. It is not only the cantankerous flathead or the uncouth barbarian who tilts against the susceptibilities and prejudices of others. It is often the man of character and ideas. Knowledge is apt to breed impatience with stupidity and irritation against ignorance, and the clever man is by no means the most popular one. The one thing to remember is that every man looks out upon the world from an absolutely distinct and individual point of view, and that to earn friendship and sympathy it is necessary to gauge your opponent's standpoint when dealing with what may seem his prejudices and wrong-headed convictions. As in heaven, so on earth, there are more mansions than one, and the keepers who start with the motto, "We are the people, and wisdom will die with us," will soon find that they are going to have a very poor time of it indeed. Let them remember the old definition: "A gentleman is a man who combines a high 
and well-grounded self-esteem with an habitual nice and delicate regard to the rights and feelings of others." Let us admit that this is no easy matter. But as John Stuart Blackie said: "Difficulties are the true test of greatness: cowards shrink from them; fools bungle them; wise men conquer them." And again: "Prudence yields to circumstance; folly quarrels with it ; pride defies it ; wisdom uses it ; and genius controls it."

As far as the keeper is concerned in his official position, his principal neighbours are the shepherd, the farmer and his labourers, the neighbouring keepers, and the townsfolk and villagers. In dealing with these let us remember that a little tact is worth a world of bullying, a little give and take more powerful for good than endless protestation and argument. In all his relations the main point to be remembered is that consideration for a neighbour's interests is the first step towards the security of one's own. And if serious difficulties do present themselves, say with prejudiced and unreasoning farmers, it is better for the keeper to refer the matter to his master, who can speak and act with greater authority than he, than for him to undertake a campaign which might make his position unpopular and even untenable. There is nothing more difficult to learn than the art of correction, unless it be the discipline of accepting it in the right spirit. The work achieved in this direction by the Services and our public schools is noteworthy and admirable. But we must remember that it is but the minority who have served 
with the colours or who have learned manly self-control at the great schools.

Let us take the case of a shepherd or his master, the sheep farmer, who may have the grazing on a moor on which the keeper is in charge of the game. Enmity or tactlessness can only result in more damage to the latter's interests than to the former's. A resentful shepherd has a tantalising habit of destroying nests and of making friends with poachers, and, by a curious coincidence, it may somehow happen that he collects his sheep on the very days when we wish the hill to be kept quiet. During the breeding and nesting season his dog has a habit of ranging the moor, with the result that many eggs are destroyed, many young birds perish, and the moor is generally disturbed. Heather is badly burned, oftentimes butts and springs are tampered with. All of which unsatisfactory state of affairs might have been different if a little tact had been used, and a friend made of the shepherd, and this friendship shown in many little acts of consideration, as helping an occasional sheep or lamb in distress, or giving information to the shepherd as to their possible danger, or as to the whereabouts of a sheep that has gone astray. The occasional present of rabbits-given, of course, with the consent of the master-is also to be recommended.

A great number of farmers are not easy to satisfy, and many have been spoiled by rich shooting tenants meeting them more than half-way. Farmers should be 
treated justly, yet firmly-in many cases the harm they do isoverrated, and used as a threat to blackmail wealthy Sassenachs innocent of anywhere except Piccadilly or the Park. Yet good relationships with the farmers are more important in low ground than on moor shootings. Here antagonism between keeper and farmer or master and farmer is possibly disastrous to good sport. Of course, farmers have no right to enter coverts, which should always be strictly reserved in the lease to the landlord. As for the farm labourers, they possess opportunities of poaching which render them particularly dangerous. They can with ease set traps, nets, and snares without being observed. Their presence in the fields seldom arouses suspicion, and they may take the opportunity of following the principle of every man for himself, unless a friendly sentiment towards the master and the keeper has stimulated their interest in sport and in justice. Far too little is attempted by the average keeper to conciliate the farm labourer, either by common human sympathy and kindness or by an occasional present, say of rabbits or hares. The keeper is far too apt to be oppressed by the idea of his own dignity, and to despise the mere clod of the fields. Let him remember that dignity does not necessarily mean austerity. A keeper can be firm and even suspicious without being "a pompous ass." We remember once, at a big covert shoot in the north of England, taking particular note of the relationship that existed between the head keeper and his corps of beaters-which was chiefly made up 
of farm labourers-hired at $2 \mathrm{~s}$. $6 \mathrm{~d}$. a day plus a scratch lunch of bread and cheese. The month was December, it may be added, and the temperature stood not very far above zero. At a glance we discovered that not only was the keeper feared-not a bad condition of affairs-but that he was actively hated. One or two stray remarks dropped by the beaters in highly flavoured Yorkshire dialect soon convinced us of this. As for the keeper, he ordered his rank and file about as if they all combined roguery with stupidityand laziness. No doubt many of his beaters were brainless, lumbering loons, but it is not always wise in this sensitive world to call a man a fool, especially when numerous adjectives of a sanguinary and condemnatory nature are prefixed. Let us not be charged with desiring the keeper to proceed, say, on these lines: "Would you mind, my dear Mr. Clodhopper, kindly accompanying the rest of the men in beating out this cover?" But there is a medium between this and the not uncommon, "Nah, then, ye —-, stir yer — legs and look sharp, you ____ Not only does such want of common consideration, such absolute ignorance of human nature-which in all its manifestations has some form of pride and self-respect, however small -tend to the ill-being of a particular shooting, it has in the long-run a damaging effect on sport in general. We do not suggest that the keeper's attitude should be one of obsequious fawning for favour, but he should remember that there are elements in society which are daily becoming more antagonistic to the game laws, and 
that there is no need for him to further emphasise the antagonism of class to class.

Let it be said, not for the first time, that on all occasions when the help of farm hands is called in for the purposes of sport, the keeper should, where such is needed, give the master a gentle hint as to the advisability of ministering well to the stomachs of these temporary employees. Irish stew or hot-pot with a little "fat ale" does not cost much, and at most would be but a drop in the bucket of shooting expenses.

Even in shootings where farm hands are not engaged, much valuable information may be at the disposal of the farm servant, and this is likely to be given or withheld in proportion to the popularity of the master, but more particularly of the keeper. Where an amicable feeling exists on all sides, sport is robbed of many of its handicaps. Good relations with the farmer may lead to the latter acquiescing in the desire that he should cut his corn towards the cover, so as to keep the birds upon the sportsman's ground. On the other hand, enmity will in all likelihood deter him from assisting the keeper, for example, by leaving a strip of uncut corn in the middle of a field so that he may drive out the game that remain in it before the reaping be finished.

A good understanding with the farmer may also checkmate the poaching facilities of his underlings. Despite his powers under the Ground Game Act, hares and rabbits will not be overshot, and orders may be given that the driver of the mowing machine should 
keep a good look out for birds, so that any possible damage may be averted. Information as to the movements and whereabouts of poachers will be placed at the keeper's disposal, and an altogether intelligent interest taken in, and considerable assistance given to, the sporting capacities of the land. Surely such a satisfactory outlook is worthy of more than condescension or mere indifference.

Let there be, at all costs, some considerable respect for the pets of the neighbourhood. The keeper should not treat all dogs and cats as vermin. If he does he will not only break the law, but also cause offence. In another chapter he will get some hints as to the law of the matter. It is only necessary to add here, that while as a rule the collie and the pet tabby should be respected, no mercy should be shown to the lurcher, or that king of poachers, Tom the vagabond. An intelligent keeper will soon discover the ownership of every living creature on his ground, and be able to judge fairly well as to the way they should be treated. There are many other points at which the interests of keeper and farmer meet, and which may suggest problems to the thoughtful man. Those we have indicated may assist him in endeavouring to meet any other possible clashing of interests in a spirit which combines tact with firmness, and justice with not too sacrificing nor yet too niggling a form of generosity.

Friendship with neighbouring keepers is an absolute necessity where there is much interchange of 
shooting. In average cases, where an owner or tenant finds a difficulty in getting assistance for his drives or beats in a not over thinly populated country, he may safely set it down either to the indolence or the unpopularity of his keeper.

Every keeper who is worth his salt will, of course, soon have a good general knowledge of the character of every man and woman, dog and cat, that comes within the radius of his shootings. He will have fairly well gauged the potential poacher and know whom to appease, of whom to seek favour, and whom to control. And of all general rules let him keep this one foremost in his mind: Let him not make a habit of drinking with his neighbours. There is a curious notion abroad in the earth that a man's courtesy is judged by his acquiescence in an expressed desire that he should have a drink. Except amongst the wisest and the most far-seeing of men, very few friendships are sealed and very little respect is born in the presence of the bottle. To drink habitually with any man diminishes authority, and no keeper can ever afford to lose that most valuable of assets. No person who counts will value a man less because he is temperate or because he refuses to give way to the silly habit of promiscuous "treating." The keeper is to be warned even of the very occasional glass with the suspicious stranger. If a man must have his glass, let him have it at home, or with men with whom he is thoroughly acquainted-men whom he respects and by whom he 
is respected-men who will neither misunderstand him nor inveigle him into slackness of duty or active mischief. The man who to-day seems a friend, and is laughing with us, may turn out to-morrow to be a poacher who is laughing at us. There is no law in the country, outside the laws of physiology and the law of any religion he may profess, that prevents a man from taking a fairly good "skinful of liquor," but the general rule must be emphasised that no drunkard, or even habitual "nipper," can retain respect, and without that priceless jewel in the chaplet of authority, a keeper had better change his profession and take to breaking stones. 
NOTES 


\section{CHAPTER IV}

\section{The Poacher}

In the last chapter we have dwelt on many points dealing with the laws of sport which affect poaching, and in our study of the various game, which it is the object of the poacher to secure illegitimately, more will be said. The days are long past when a halo of sentiment hung round this law-breaker. He no longer inspires the song writer or the writer of romance. "The Lincolnshire poacher" and his contemporaries were no doubt men with a glamour about them, instinctive hunters, impatient of the trammels of game legislation, and lineal descendants of a breed of sportsmen that knew not Acts of Parliament, and had no fear of the power of the constable and the police court. But the glamour has passed, like many a glamour of simpler and freer days. The twentieth century poacher is an ill-conditioned, lazy, drunken, and slinking scoundrel, an enemy to law and order, without a particle of true sportsmanlike feeling in his veins. Taken as a class, poachers are a set of hardened criminals, careless of everything but their own besotted lives. The occasional poacher is a much rarer bird, and is the uncurbed 
expression of the natural poaching tendency which exists in human nature. He may be a farm hand, a village loon, or even a medical student home for the vacation, but whatever he may be, he is in the majority of cases an amateur and not so dangerous as his professional brother, who is a cast-off from honest trades-a grain in the sediment of society. Drink has him, as a rule, in its grip. He has a shifty and congested eye and a tremulous tongue. He is the friend of no man and an enemy to most, and is in the majority of cases an arrant coward. Remarkably ignorant on most questions, he is terribly acute on all matters affecting the poaching of game, and although a coward, he is prepared at a pinch to get rid of another life to keep the security of his own.

There used to be a popular impression that the best man to secure as a keeper was one who had been a poacher. If we limit the word "poacher" to the occasional, and not the habitual, criminal, there may have been some truth in the belief, but, for our purposes, there is much more wisdom in the reverse statement that the best poacher is the man who has been a keeper. A gamekeeper discharged for drunkenness or dishonesty is a dangerous man to deal with, especially if he continues to hang about the district in which he formerly had respectable employment. He is thoroughly conversant with every preserve in the county, and knows to a nicety the habits and habitats of the game in the district. The inference is obvious. He is the very man to lead a gang of poachers. It is therefore 
unwise to allow a discharged keeper to remain on the property.

Generally speaking, the only way to put down poaching is by firm determination and constant action against the wrong-doer. The fact that the keeper is soft or overlooks the inroads on his preserves is not appreciated, and indeed only encourages the poacher to increase his depredations. The poacher must be kept in order by fear, and not by kindness. With most dishonest people of this class the virtue of kindness is mistaken for that of weakness.

We have indicated, in a previous chapter, the line of conduct which it is advisable for keepers to pursue in dealing with men who are potential poachers-farm servants and the like-and it will not be necessary for us to say more on the subject. In dealing with the professional poachers, individually or in gangs, in addition to such usual procedure as the bushing of fields to prevent partridge-poaching, the construction of wire and bells in pheasant coverts and by pheasant coops, and other forms of special protection, it will be necessary that the keeper should institute a regular system of watching, and a system which is flexible enough to stand modification in time and season. The nesting season, and the days when birds are young, must be periods for particular alertness. A cloudy, windy night must at once suggest to the keeper the idea of special vigilance, for this condition of weather offers an especial chance to the plans of the poacher. The artful keeper 
also should not get into the habit of making regular rounds-he should vary them daily.

When a district is habitually invaded by gangs of poachers, the keepers of neighbouring estates should work in unison, and should lay their heads together to carry out a joint plan of campaign to frustrate the villainy of the trespassers in pursuit of game. The use of rockets as signals is an excellent practice and should be more generally carried out. Not only do rockets give warning to keepers at a distance, but they put fear into the heart of the cowardly poacher, who, as a rule, takes to his heels on the faintest suspicion of danger. It is advisable not to give too long notice to beaters as to the locale of a shoot, as poachers are apt to mature their plans for another part of the ground. Late the night before, or, better still, early the morning of the day on which the shooting is to take place, is soon enough.

Finally, letgamekeepers befeared. There is nothing like a reputation for strength to keep off the intruder. There is much to be gained when the keeper is held in awe. To illustrate the truth of this remark, we may quote an experience of our younger and more irresponsible days. One of the present writers had a lease of a shooting in the Upper Ward of Lanarkshire, an estate with excellent covers, in which were preserved a large stock of pheasants. He had been much troubled by the inroads of poachers, and had a suspicion that they were, in fact, stimulated by the "softness" of the 
head-keeper. Mr. Gaiters was a mild-speaking, humorous, yet patient and godly man, and despite his honest endeavours toget the better of his unscrupulous enemies, the victories were generally on their side. Things went from bad to worse till one eventful night. The tenant had retired to his smoking-room for the evening, when a servant came running in to inform him that a big tussle was going on at the end of one of the coverts, owing to the fact that a gang of poachers had been surprised in their work by the head and under-keeper. From the account he received, he imagined it to be an encounter of the first magnitude. He was about to set out for the field of action when an eccentric idea came into his brain. He rushed to the gunroom, took down his gun, putsome cartridges into his pocket, and "rushed into the night." As soon as he got within fifty yards of the cover in which the "fun" was proceeding, he loaded his gun and began to empty cartridge after cartridge on to the tops of the trees. He could hear the tramp of feet in the distance and the evident sound of struggle. When he ceased firing, this sound ceased also. Another servant at this moment came running up, and then the second part of the coup was carried out. A sheep had been killed that very day, and he immediately gave orders that some of the blood should be brought to him. This he mixed with water in a bucket. He then secured an old pair of tweed trousers, which he roughly tore into pieces. Accompanied by his servant, he now set out for the cross-roads near to 
the point where the encounter had taken place. In a few moments the watered blood and the tattered garment had been scattered indiscriminately here and there about the road, and two pairs of feet began to trample them into the mud and dust. The night was so dark that the immediate effect was not discernible. Having completed this piece of work, he returned to the house, and, warning his servant to keep a quiet tongue in his head, retired to bed. Next morning there was "the devil to pay." An early visitor in the shape of a constable found an unusually early riser in the shape of the shooting tenant, who listened with keen attention to a story of the strange doings of the night before. The constable suspected manslaughter, though no body had been found. His hearer, evidently much impressed with the seriousness of the situation, accompanied him to the cross-roads, where already a small crowd had collected, peering into hedges and over dykes to find a mutilated corpse. For the roadside presented a gruesome spectacle. Even the innocent humorist was impressed by the ghastliness of the experiment. As for the head-keeper, he was quite nonplussed. The fight had been a severe one, but he could not account for the roadside shambles. The constable was, of course, sceptical at his mild protestations, and the crowd voted him a new quality of humour. However, to cut a long story short, there was a private interview between tenant and constable, and " the smile on the face of bobby "was modified by the fact that he discerned a 


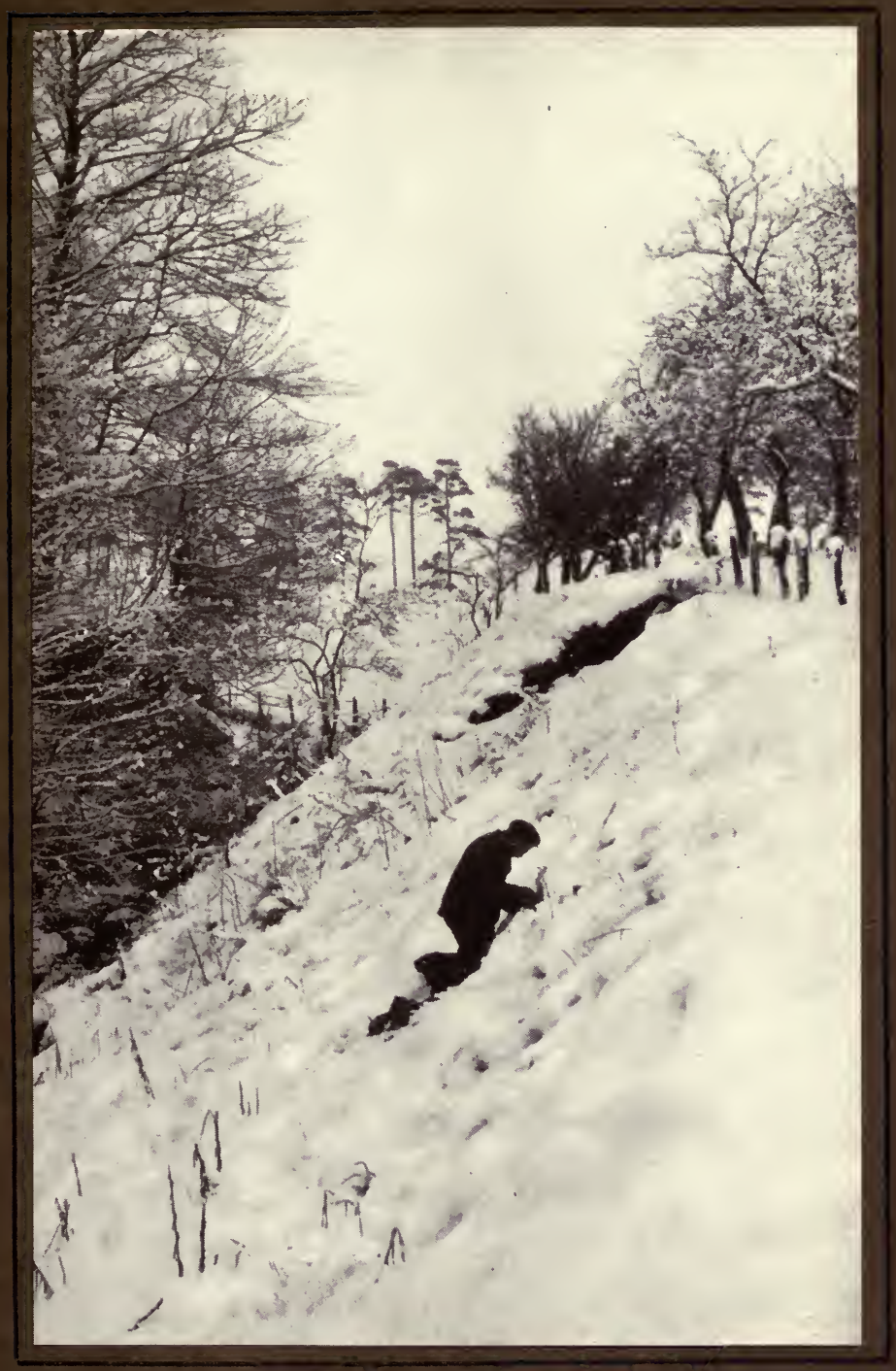

A POACHER. 
new way of keeping the law. The moral of which tale is, that a reputation as a fighting man, and one whose blows do not merely go skin deep, is not an objectionable adjunct of the character of a keeper. 
NOTES 


\section{CHAPTER V}

Points in Law a Gamekeeper should Know

By H. BURN MURDOCH, Advocate and Barrister-at-law.

Master and servant.-Fortunately the relations existing between gamekeepers and their employers are very often so satisfactory, and even so cordial, that questions of the legal rights of parties rarely have to be discussed. It is always well, however, to know the nature of one's legal rights : they form part of the general law of master and servant which may be found explained in many large volumes. Only a very short statement can be given here. As to the contract of service, this will follow any conditions upon which both parties agree, as to length of service, wages, notice, etc. If no mention is made of the duration of employment, this is presumed in Scotland to be by the year, and whether by the year or half-year, forty days' clear notice must be given before the end of the time in order to end the contract. In England, disputes on such subjects are usually settled by a jury, and the results of this are so uncertain that no rule can be exactly stated. It has, however, been decided that a head-gardener falls into the large class of 
employees who are engaged on the common terms of a month's notice or a month's wages. Probably a keeper's employment will be presumed to be on the same terms in England and Ireland unless a different bargain is made.

But the contract will be broken and ended without any period of notice in certain cases. These may be shortly expressed as-( I) Disobedience of lawfulorders, or want of proper respect; (2) Dishonesty, drunkenness, insubordination, or other serious misconduct; (3) Incompetence, general neglect, or absence from work. Where a servant breaks his contract by some such misbehaviour, he loses his right to any wages for the time since the last period of service and the date when wages were last due. Thus, if a keeper were employed and paidby the half-year, ending say at Whitsunday, but was justifiably dismissed a few months or weeks before, he would not be entitled to any wages for the incomplete period. On the other hand, if unjustifiably dismissed, he would be entitled to the whole wages up to Whitsunday, even if dismissed months before. The employer must keep his side of the contract by paying the wages agreed upon at the proper time. He must be a reasonable master, and, for example, must not expect a head-keeper employed as such to serve as underkeeper.

It would perhaps be harsh to refuse to give a written "character" to a good servant, but it must be said that a master is under no legal obligation to do so. Indeed, 
he becomes responsible if he does, and if some other employer were deceived by a false and flattering testimonial, might be held liable in damages for any resulting loss. But a communication regarding a servant's character which a master makes to a prospective employer is privileged, that is to say, the writer will not be held legally liable for anything said honestly and without malice, even if it is uncomplimentary and incorrect.

Should a keeper suffer personal injury by an accident arising out of his employment and in the course of his work, he will be entitled to recover compensation from the master under the Workmen's Compensation Act if any loss of wages results. Notice in writing of the accident must be given, and within six months from the occurrence a definite claim must be made for compensation. He will have no right to compensation where the accident was due to his own "serious and wilful misconduct" unless it causes serious and permanent disablement. It is desirable for the employer to insure against this risk, for heavy liabilities may be suddenly incurred without any one being to blame.

Keepers, like many other agents and employees, frequently have to trade with dealers and tradesmen on behalf of their employers. Tempting opportunities are sometimes given by dealers and others to make a profit by a "commission" or "discount" on the account, or in some similar way. It is necessary to keep in mind that all such secret profits by a servant or agent are 
improper, and that now any one who "corruptly" offers or accepts such secret commissions is liable under the criminal law. A keeper should accept nothing of the kind without the full knowledge of his master. He will then be all right, not only with the law of the land, but also with his own self-respect.

The whole subject of game, in regard alike to its preservation and its destruction or capture, is so fenced about by law, that no keeper can properly do his work without knowing at least the main restrictions which the law places on himself and others. Space forbids that more than an outline be given here, but for the sake of those wishing more detailed information a list is given at the close of the chapter of the leading books on the subject. The law on the subject is in rather a confused state, owing to the careless wording of Acts of Parliament. Those who are fond of abusing lawyers and the law should remember that most of the law has been manufactured in Parliament by laymen!

Game, in its general sense, means all birds and beasts which are both used as food for man and are usually shot or hunted by man for sport. But the word is also used in the narrow sense of the birds and beasts mentioned in the leading Game Act of each of the Three Kingdoms. These are hare, pheasant, partridge, grouse, heath or moor game, black game, and bustards. (Heath game and moor game only mean black game and grouse respectively.) For Ireland add deer, landrails, and quail. In Ireland "moor game" is also 
supposed to mean black game and ptarmigan. Many Acts of Parliament use the word game in this sense when they state that the provisions of the Act apply to "game and rabbits, teal, widgeon, deer," etc. By various Acts it has been made illegal to kill birds during the nesting season. A table of the close times for each species of game is given at the end of this chapter.

Ownership of game.-There is no property in game orother wild animals in their natural state. In Scotland they become the property of whoever captures them (in the legal phrase, "reduces them into possession"), even if the captor breaks the law in taking them, unless forfeiture of the game is made a part of the penalty for the offence. In England and Ireland the law is more complicated. There, if game is flushed and killed on the ground of one proprietor, it becomes his property. If it is flushed on the ground of one man and killed or captured on another's ground, it becomes the property of its captor. Young game unable to leave the nest, or, at least, the soil of its home, is the property of the owner of the soil. In all three countries tame animals (or those which have been tamed) are the property of the person who keeps them. Young pheasants, hatched from a setting of eggs by a barn-door hen, are considered to be tame so long as they follow their foster-mother. To steal them is therefore punishable as theft or larceny, and they do not require the protection of the game laws. Dead game also does not fall under the provisions of the game laws, which do not make it a special offence 
to appropriate dead meat. But it is not ordinary theft to take game before it has become the property of some one, that is to say, in the usual case, before it is killed and bagged. This leads to a curious result : if, for instance, a man, passing along a public road while pheasants are being shot on the adjoining land, picks up a dead bird that falls at his feet and walks off with it, he is not guilty either of theft or of breaking the game laws. The Courts have so decided in Scotland, and although there is no decision quite so clear in England or Ireland, the law is understood to be the same.

In England and Ireland the property in game is sometimes affected by the peculiar privileges belonging to royal forests, chases, purlieus, parks, free warrens, and manors. The keepers on such estates have also exceptional powers, but such privileged places are not so numerous as to require notice here.

Shooting rights.-The right of hunting and shooting game (which is a different thing from the property in the game) belongs naturally to the owner of the ground. In Scotland this right remains with the proprietor, though he lets the land on an agricultural lease, unless the lease contains an express stipulation that the tenant should have the game rights. In England and Ireland the agricultural tenant has the game rights unless the lease contains a contrary stipulation. This, however, is subject to what must afterwards be said about the Ground Game Acts, which apply to all three countries. Of course the owner of the land may let the game rights 
to a sporting tenant, and the farming rights to an agricultural tenant. In such a case disputes may easily arise between the two tenants if either exercises his rights in such a way as to interfere with the rights of the other. The law is, that each is fully entitled to exercise hisrights, provided he does so in such a manner as not to interfere unduly with the rights of the other. For example, the sporting tenant must not tramp through a field of standing corn, but he is quite entitled to walk through turnips after partridges, provided he does not unnecessarily trample down the turnips or go so frequently through them as to damage the crop seriously. The rights of the game tenant (or the landlord, when the shooting is in his own hands) include a right to enter on the land during the close time for game for the purpose of killing vermin and otherwise protecting the game, provided he does not unnecessarily or unduly interfere with the agricultural tenant. Of course, each case must be judged by itself, but the rule for the keeper to remember is that the Courts will only protect him in his duty if he acts with reasonable consideration for the farmer's rights.

Damage done by game.-When a landowner lets a farm to an agricultural tenant, reserving to himself the game rights, hebecomesliable for damage to the farmer's crops by game unless he shoots the game regularly, so as to prevent the stock becoming excessive. This does not apply to hares and rabbits, because all farmers are entitled to kill these for themselves, and by doing so 
can remove any cause of complaint. In the case of damage by deer, pheasants, partridges, grouse, or black game, amounting to more than one shilling's worth of harm done per acre over the area damaged, any tenant can now claim an arbitration with his landlord to recover money compensation. In order to do so he must give the landlord written notice of the damage and of his claim, and must provide sufficient opportunity for an inspection of the damage upon the landlord's behalf before the crop is raised or cut, or if a reaped crop is damaged before it is removed from the field. There is no right to compensation for damage done by any kind of deer or game which the tenant himself is entitled to kill. This right to compensation is statutory, and the tenant cannot contract to do without it, but in fixing the amount payable there must be deducted any sums of money compensation which the tenant is entitled to independently under his contract or lease. Any compensation which the landlord has to pay under this law may be recovered by him from the shooting tenant.

Farmers' rights of shooting and trapping.-Any farmer or agricultural tenant may also possess such rights of shooting as he has contracted for with his landlord under the lease. Apart from this, the Ground Game Acts give to every occupier of land the right (of which he cannot divest himself) to kill the hares and rabbits on his holding. The right may be exercised by the occupier or persons authorised by him in writing. The occupier and one other person so authorised are 
the only persons who may use firearms. No person shall be authorised by the occupier to kill ground game except-(I) Members of his household resident on the land; (2) Persons in his ordinary employment on the land; and (3) One other person bonâ fide employed by him for reward to kill ground game. The keeper, if authorised in writing by the landlord or game tenant (who has a concurrent right to kill ground game), may demand any person killing game for the occupier to produce his written authority. If he has none he may be prosecuted as a poacher. This Act also forbids the use of firearms at night (i.e. from end of first hour after sunset to beginning of last hour before sunrise), and the use of spring traps except inside rabbit holes. The right of killing ground game under this Act must not be exercised on moors or unenclosed lands which are not arable, except from the Ist day of September in any year till the 3Ist day of March in the following year, both dates inclusive, and no shooting is permissible until I I th December - a provision probably designed to favour the grouse.

Heather burning. - In Scotland and I reland, but not in England, farmers are accustomed to burn the heather and old grass or bent on the moorland pastures periodically. This operation, known as "muirburn," is also beneficial to the grouse, as they feed on the young shoots of the heather or ling which come up afterwards. Obviously a moor cannot be burned without risk of damage to growing woods, etc., by the fire spreading, and the 
certainty of some damage to wild birds' nests on the ground burned. To burn too large an area in any one year is unnecessary for the sheep-farmer and very bad for the stock of grouse. Most leases of such ground in Scotland therefore regulate the amount which can be burned in any one year; and by Act of Parliament such burning may not be done between I I th April and Ist November in any year, except in the case of high, wet moorlands, which, by leave of the proprietor in writing, may be burned between I I th and 20th April. ${ }^{1}$ Under some farming leases the landlord contracts to do all necessary burning himself. In such cases the farmer is entitled to havea proper proportion burned regularly, and may recover compensation if too much ground has been left under old heather. In Ireland the burning is permitted only between i 4 th June and 2 nd February. In both countries a penalty is incurred if the Act is broken.

Gun licences, etc.-These being the leading conditions as regards the persons legitimately on the lands which the sportsman must observe, the conditions in regard to the Government are chiefly contained in the provisions as to licences. The second table at the end of the chapter shows all the licences required in the Three Kingdoms, and the times during which they run. In the remarks following it is assumed that the reader has that table before him. A licence as a male servant is not required for a servant who is bonâ fide employed in a capacity not requiring such a licence (as, e.g., a farm

${ }^{3}$ See page $15 \mathrm{I}$. 
labourer), though he should be taken for an odd day to beat a covert or to kill vermin, or to do any duty for a gamekeeper. Similarly a gun licence is not required by a person sent out with a gun to kill vermin-i.e. animals of a purely noxious kind, such as weasels, stoats, etc. At one time it was thought that rabbits were vermin, but it has now been settled that no one can shoot rabbits, even under the Ground Game Act, without a gun licence. The only exceptions from the need of agame licence which require notice here are-(I) The taking or destroying of conies (rabbits) in Great Britain ; (2) the killing of hares- $(a)$ in England, by one person authorised in writing by the occupier of the land; $(b)$ in Scotland, by the owner or lessee of any land, or any person authorised by him in writing; (3) the killing or taking of ground game under the Ground Game Act ; (4) coursing or hunting hares or deer with hounds; and (5) the taking of woodcock or snipe with nets or springes in Great Britain. A keeper's game licence can only be taken out by his employer, who has himself a full licence to kill game. Such a licence is not available except on the land on which his employer has the right to kill game. Such a licence may be transferred to a new keeper, if the keeper for whom it was taken out dies or leaves his employment while the licence is current. The officer of excise who issued the licence must indorse the name of the new keeper on the licence before the transference can take effect.

Gamedealers' licences.-Only persons who hold the 4 
licence to deal in game may sell it retail or buy it wholesale, whether alive or dead. ("Game" includes hares but not rabbits.) The only persons entitled to sell to such licensed dealers are those who have taken out the full $£ 3$ licence to kill game. It is the received opinion that a gamekeeper holding a $£ 2$ licence may lawfully sell game to a dealer on the account and with the written authority of his master (who must have the full $£ 3$ licence), provided that he only sells game killed on lands over which his employer has the right of shooting. (The statutory sections, which on this point are rather confused, are 23 and 24 Vict., c. 90 , s. 17 , and $\mathrm{I}$ and 2 Will. IV., c. 32, ss. I7, 25 : see Highmore's Excise Laws, 2nd Ed., Part II., p. I8I.) Another exception is introduced by the Ground Game Act, I880, in favour of persons killing ground game under that Act, who may sell such game killed by them to a licensed dealer though they have not a licence to kill game.

Showing licence.-Any person doing any act in Great Britain for which a licence to kill game is necessary, must show his licence to, and allow a copy of it to be taken by, any officer of Inland Revenue, or any person dulylicensed to kill game, or the owner, occupier, or gamekeeper of the land on which he then is, who demands to see his licence. If the licence is not produced, the person must give his true name and address and state the place where he took out the licence, under a penalty of $£ 20$ in case of refusal, or of the information proving false. 
Licences in Ireland - The laws of Ireland in regard to this part of the subject are too complex to be adequately treated in the space at our disposal, nor is it necessary in a book expressly for keepers. No reference, therefore, is made to such questions as property qualification, manorial privileges, and those of " persons not under the degree of an esquire," and, in short, all matters with which an ordinary keeper is not concerned. No licences as male servants are required in Ireland. Licences for dogs must be got on 3 Ist March in each year, from the Petty Sessions Clerk of the district. Duty, 2s. for each dog, and a 6d. stamp on the certificate of registration. A gamekeeper in Ireland, instead of taking out a licence to kill game, registers his deputation or appointment (which is chargeable with a ros. stamp duty) with the supervisor of excise within whose district the lands are situated, and the officers of excise thereupon, on payment of the duty (i.e. Ł3), grant a certificate to such gamekeeper to kill game. Such certificate may be transferred to a new keeper if the keeper to whom it is granted dies or quits the service, just as in the case of a keeper's licence in England and Scotland. There is a provision in Ireland about showing a certificate to kill game on demand similar to that in England and Scotland, with two differences, viz. (I) Theperson making the demand must show his certificate, which is not necessary in England or Scotland, and $(2)$ the penalty for refusing to show is $£ 50$, not $£ 20$. Laws against poaching.- The keeper's legal powers 
and duties in regard to persons who come on the ground with no legitimate title to be there (whom we may call generally "poachers") cannot be stated intelligibly without first giving a short outline of the legislation for the protection of game against such persons. For all practical purposes the law is contained in a very few Acts of Parliament, the first of which was passed in 1828 and the last in 1862 . The subject is divided into three parts-(I) Trespassing in pursuit of game in the night time: (2) trespassing in pursuit of game in the day time; and (3) the prevention of poaching.

Night poaching is forbidden by two Acts, which both apply to the whole United Kingdom, viz. the Night Poaching Acts, 1828 and 1844 .

For the purpose of both Acts night is defined as the period between the expiration of the first hour after sunset and the commencement of the last hour before sunrise, and "game" is defined as including hares, pheasants, partridges, grouse, heath or moor game, black game, and bustards.

An offence under these Acts is committed by any person who, during the night, (I) unlawfully takes or kills any game or rabbits on any land, or on any public road or path or the sides thereof, or at the openings or gates from any such land into such road or path; or (2) unlawfully enters, or is on such land (no mention of roads, etc.), with any instruments for the purpose of taking or destroying game. Entering land for the purpose of taking rabbits is only punishable under these 
Acts when at least three persons are together and any of them are armed with firearms, bludgeons, or other offensive weapons. But this does not make it lawful for single individuals to trespass by night in pursuit of rabbits. A person caught on the ground with poaching instruments, such as nets, and charged with being there in pursuit of game, could hardly defend himself by saying he only meant to take rabbits.

Arrest of night poachers.-Any person committing the offence first mentioned may be arrested and given into custody by the owner or occupier, or by his gamekeeper or servant, or any one assisting such gamekeeper or servant, wherever he may be seized, provided the pursuit started on the land. Any one committing the offence second mentioned may be similarly arrested and given into custody, provided the seizure be made, or the pursuit begun, on the land on which the offence is committed. In either of these cases an assault by the offender on any person authorised to arrest him is a serious aggravation of the offence. A person authorised to make such arrest may, without being guilty of assault, use sufficient violence to effect this arrest. In Scotland a person not so authorised would commit an assault by the attempt to arrest and be liable in damages to the poacher if he used violence, while the poacher who violently resisted the unauthorised attempt to arrest him would be justifiably acting in self-defence. In England and Ireland the Prevention of Offences Act, I 85 I, section II, authorises any person whatsoever to 
apprehend any person found committing an indictable offence in the night; and this has been held to authorise any one to arrest a person found committing an aggravated offence against the Night Poaching Acts. It is an aggravation of these offences if they are committed by three or more persons acting in concert, provided any of them be armed with gun, bludgeon, or other offensive weapon.

Day poaching.-T respassing in pursuit of game by day, i.e. between the commencement of the last hour before sunrise and the expiry of the first hour after sunset, is a less serious offence than night poaching, and the law is different in each of the three kingdoms.

Day poaching in Ireland.-Trespassing in pursuit of game in daylight is prohibited by the Game Trespass Act, I 864. It needs no further mention here, as it confers no special power on any one to enforce it or turn trespassers off the ground, but merely provides a penalty for such trespass. The keeper there must rely on his common law right to turn trespassers off the land on his master's orders.

Day poaching in Scotland. - The law is fixed by the Day Trespass Act, officially called the Game(Scotland) Act, 1832. This Act imposes a penalty on any one who trespasses on any land in the daytime (as defined above) in pursuit of game or of deer, roe, woodcocks, snipes, quails, landrails, wild ducks, or conies (i.e. rabbits). The penalty is larger if the offender have his face blackened or is otherwise disguised. A man who re- 
mains on the high road may commit the trespass by sending his dog into a field to chase rabbits or by acting in concert with others who are in the fields in pursuit of game, etc.

A man who has a perfect right to be on the lands for another purpose may be convicted under this Act of " unlawfully entering" if he takes game when on the lands. For example, a farm servant whose employment requires him to be on a particular field to plough, becomes a trespasser if he takes game on that field.

Any such trespasser may be required, by the person having the right to kill game on the land, or theoccupier, or the gamekeeper, or other person authorised by either of them, to quit the land and give his full name and address. If he refuses to do either of these things, the gamekeeper or other such person may apprehend the offender and take him before the Sheriff. If the offender cannot be brought before the Sheriff within twelve hours of his arrest, he must be discharged, but may be proceeded against for his offence by summons or warrant. The gamekeeper (or other) may also require the offender to give up any game he has with him, and, if he refuses, may take it from him.

The gamekeeper cannot be sued for anything wrong he has done in carrying out the Act after six months have elapsed since the act complained of.

A trespass to pick up dead game is not an offence under this Act.

Day poaching in England.-The law as to day 
poaching is contained in the Game Act, I83 I. By that Act a penalty is imposed on any one who trespasses in the daytime (defined above) on any land in pursuit of game or woodcocks, snipes, quails, landrails, or conies. The penalty is increased if five or more persons so trespass together. As in Scotland, the offender or offenders may be ordered to quit the land and to give their names and addresses, and, on refusal, may be arrested and taken before a Justice of the Peace. If they cannot be brought before a Justice within twelve hours, they must be discharged, but may be proceeded against for the offence by summons or warrant. They may also be required to give up any game in their possession. The persons authorised in England to make and enforce these demands are the persons having the right of killing game on the land, the occupier of the land, any gamekeeper or servant of either of them, or any person authorised by either of them, or, where the offence takes place in a royal forest, park, chase, or warren, the warden, ranger, verderer, forester, master-keeper, underkeeper, or other officer thereof. Armed resistance aggravates the offence. In England, persons who unlawfully hunt, wound, or kill any deer in parks or inclosed lands are guilty of felony, whether by night or by day.

The Poaching Prevention Act, 862 (25 and 26 Vict. c. I I 4), applies to the United Kingdom. For the purposes of the Act, "game" includes any one or more hares, pheasants, partridges, woodcocks, snipes, rabbits, 
grouse, black or moor game, and eggs of pheasants, partridges, grouse, and black or moor game. The Act empowers any constable or peace officer in any highway, street, or public place to search any person whom he may have good cause to suspect of coming from any land where he was unlawfully in pursuit of game, or any person aiding or abetting him, and having in his possession any game unlawfully obtained, or any gun, part of a gun, or nets or engines used for killing or taking game, and also to stop and search any cart or conveyance in which such constable shall have good cause to suspect that any such game or such articles are being carried by any such person, and if he (the constable) finds such game or articles, to seize and detain them. It must be noted that the powers of search and seizure conferred by this Act are conferred on constables and peace officers only. Consequently all that the keeper can do to carry out this Act is to give information to the constable, if his covers have been disturbed by poachers, or if he has other reasons for supposing that poaching is going on.

Things forbidden by law.-What the gamekeeper must not do may be stated more shortly.

Poison.-In all three countries it is absolutely forbidden to put poison in any shape or form upon any land, enclosed or unenclosed. This prohibition is not only contained in many Acts relating to game, but is extended by Special Acts to the use of poison for any purpose-with the sole exception of the use of poison, 
under very strict precautions, about a house or steading for the destruction of rats, mice, and such small vermin. In connection with this exception, the gamekeeper must see that means are taken to prevent any dog from getting at such poison.

Shooting on Sunday or at night.-In England and Ireland it is illegal to kill game on Sunday or Christmas Day. There is no such direct prohibition in Scotland, but the Act I66I, cap. I8, which has been held to be still in force, prohibits salmon-fishing and all other profanation of the Sabbath day. It is doubtful whether this Actis nowadays in force, and a conviction for shooting on Sunday could not probably be obtained if the shooting did not go on so near to houses or churches as to cause serious annoyance.

The use of firearms by night to kill ground game is forbidden in all three countries, but the Acts forbidding this in regard to other game do not extend to Ireland. In England no one may use firearms within fifty feet of the centre of a public roadway. In Scotland no one may use firearms on or in any exposed situation near a public roadway so as to cause annoyance to any passenger thereon.

The Wild Birds Protection Acts.-One of the ordinary duties of the keeper is the destruction of vermin which might destroy the game which it is his duty to preserve.

By a series of Acts (extending to the whole United Kingdom) for the preservation of wild birds, it is pro- 
vided that a schedule be prepared for each county of all the wild birds which are supposed to be quite harmless ; that the owner or occupier of the land, or any one authorised by him, may at any time kill the birds not included in the schedule; but that no one may kill the scheduled birds between Ist March and ist August in each year ; and that no one except such owner or occupier or person authorised by either may kill any bird between these dates.

The keeper will do well, before killing any birds between these dates in order to protect his game, to make sure that such birds are not included in the schedule for his county, by application to the county clerk. Two recent Wild Birds Protection Acts forbid the use of pole-traps or hooks for the purpose of birdcatching. Every person "who on any pole, tree, or cairn of stones or earth shall place any spring trap or gin, calculated to cause bodily injury to any wild bird coming in contact therewith" commits an offence punishable with a fine of forty shillings, or five pounds on a second conviction. Any one who knowingly permits it to be done is equally liable. By the Act of 1908 , any person "who shall attempt to take any wild bird by means of a hook or other similar instrument" is made liable to the same penalties.

"Poaching" dogs and cats.-The ordinary gamekeeper has no right to kill a dog or cat which is poaching on the land under his charge. By so doing he makes himself liable to have a civil action brought against him 
by the owner to recover the value of the dog or cat. If the dog or the cat is in the act of killing a valuable bird or animal, the keeper might be held entitled to kill such dog or cat, provided this were the only means of saving such valuable animal or bird. The cases in which this defence has been upheld are so rare that it would be safer for the ordinary keeper to refrain from such killing. Special powers, however, are given to the gamekeepers of any lord of the manor, lordship, or royalty, duly appointed under the hand and seal of the lord on a ten-shilling stamp, and registered with the clerk of the peace for the county. A keeper so appointed may seize and take for his master's use any dogs, nets, and other instruments for taking game as shall be used within such manor by any person not authorised to kill game.

Similarprivilege is conferred upon the gamekeepers duly appointed in the same manner upon any lands in Wales of the clear annual value of $£ 500$. By the Dogs Act 1906, "any person who takes possession of a stray dog" must either return it to its owner, or else send written notice to the chief police officer of the district, stating full particulars, under penalty of forty shillings.

Spring-guns. - A keeper must not set any springgun or any trap which might be destructive either to men or dogs, but it is quite lawful to set a spring-gun with a detonating cartridge, which can only act as an alarm signal.

It is hardly necessary to say that a gamekeeper 
who fires a gun at a poacher may be tried for assault or murder, as the case turns out. Keepers, like policemen, are sometimes placed in a very difficult position when they have to deal with dangerous characters. The legal rule is strict that in preventing crime the guardians of law and order must use no more violence than is absolutely necessary for the purpose. But anything is legal which is really required in self-defence, and even the killing of a wrong-doer is justifiable if nothing else can save the life of an innocent person.

The question sometimes arises how far a person shooting may follow his wounded game on to the land of a neighbouring proprietor. The rule is that he may follow game which is dead or on the point of death. In this connection it may be noted that to enter land for the purpose of taking dead game is not a breach of the Day Trespass Act.

In regard to fishing, the law lays no special duties on the gamekeeper and confers on him no special privileges, so nothing need be said on that subject in this chapter. Angling law is dealt with in Chapter XX.

Leading books on the game laws in the different countries :-

Scotland-The Law of Scotland on the Game Laws, Trout and Salmon Fishing. J. H. Tait. I5s. Edinburgh: William Green \& Sons. 190r.

England-Oke's Game Lawe. J. W. Bund. 14s. London : Butterworth \& Co. 1897. Practical Guide to the Game Laws. C. Row. 5s. net. London: Longmans \& Co. 1907.

Ireland-The Irish Game Laws. M'Carthy Conner. 6s. Dublin : Hodges \& Figgins. 1891. Supplement. Is. 1903. 


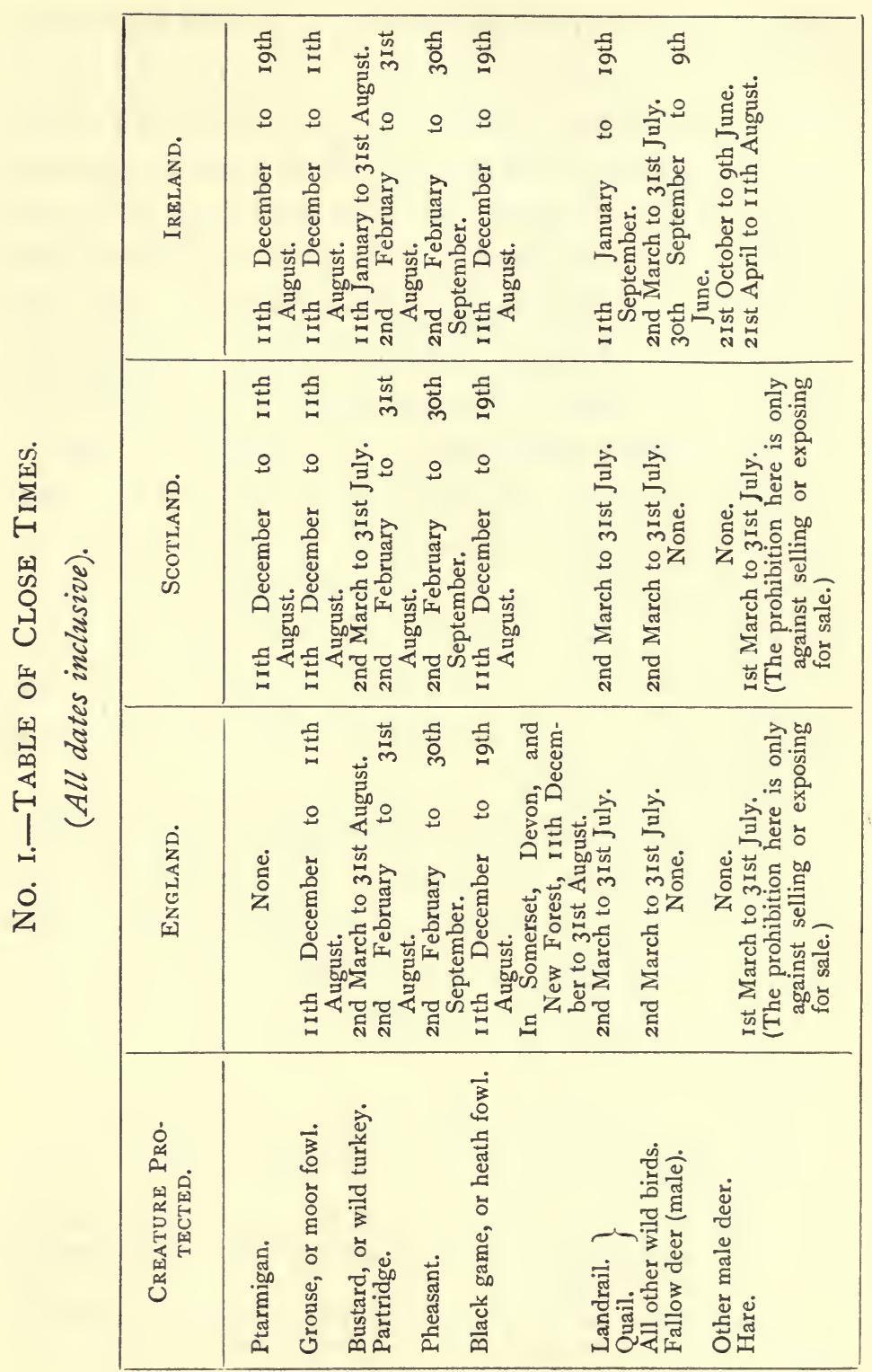




\begin{tabular}{|c|c|c|c|c|c|}
\hline 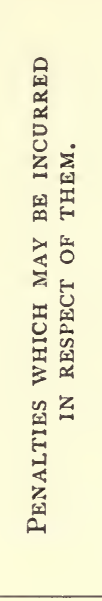 & 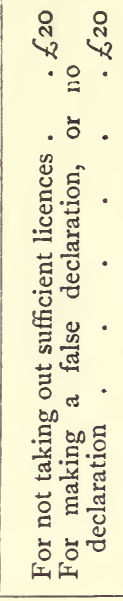 & 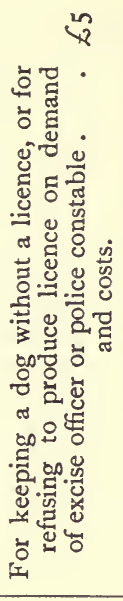 & 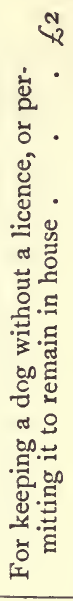 & 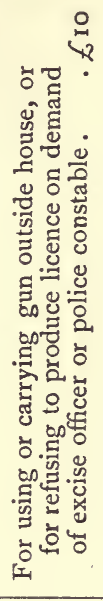 & 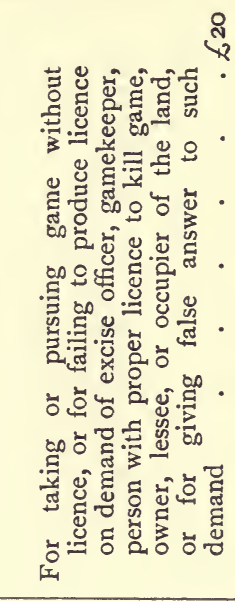 \\
\hline 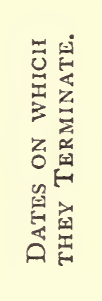 & 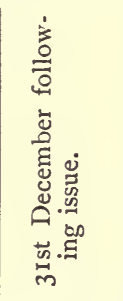 & 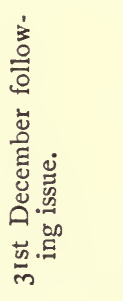 & 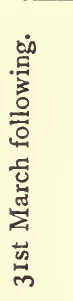 & 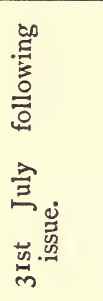 & 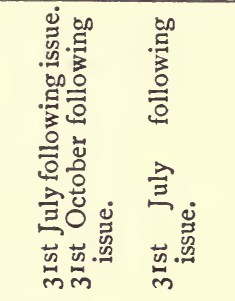 \\
\hline 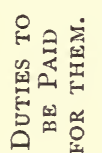 & $\begin{array}{l}\text { si } 0 \\
\text { in } \\
\text { wo }\end{array}$ & $\begin{array}{l}0 \\
1 \\
0\end{array}$ & $\begin{array}{l}0 \\
0 \\
n\end{array}$ & $\begin{array}{l}\circ \\
\circ \\
\circ\end{array}$ & $\begin{array}{l}0 \\
0 \\
0\end{array}$ \\
\hline 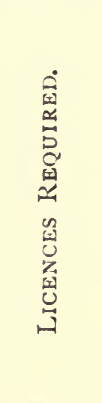 & 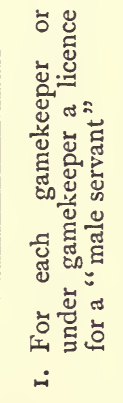 & 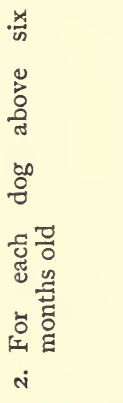 & 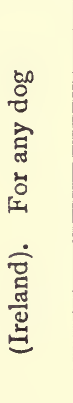 & 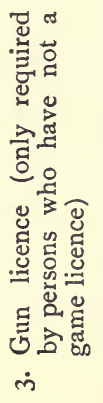 & 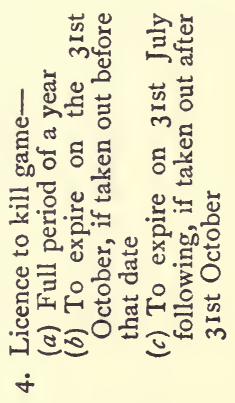 \\
\hline
\end{tabular}




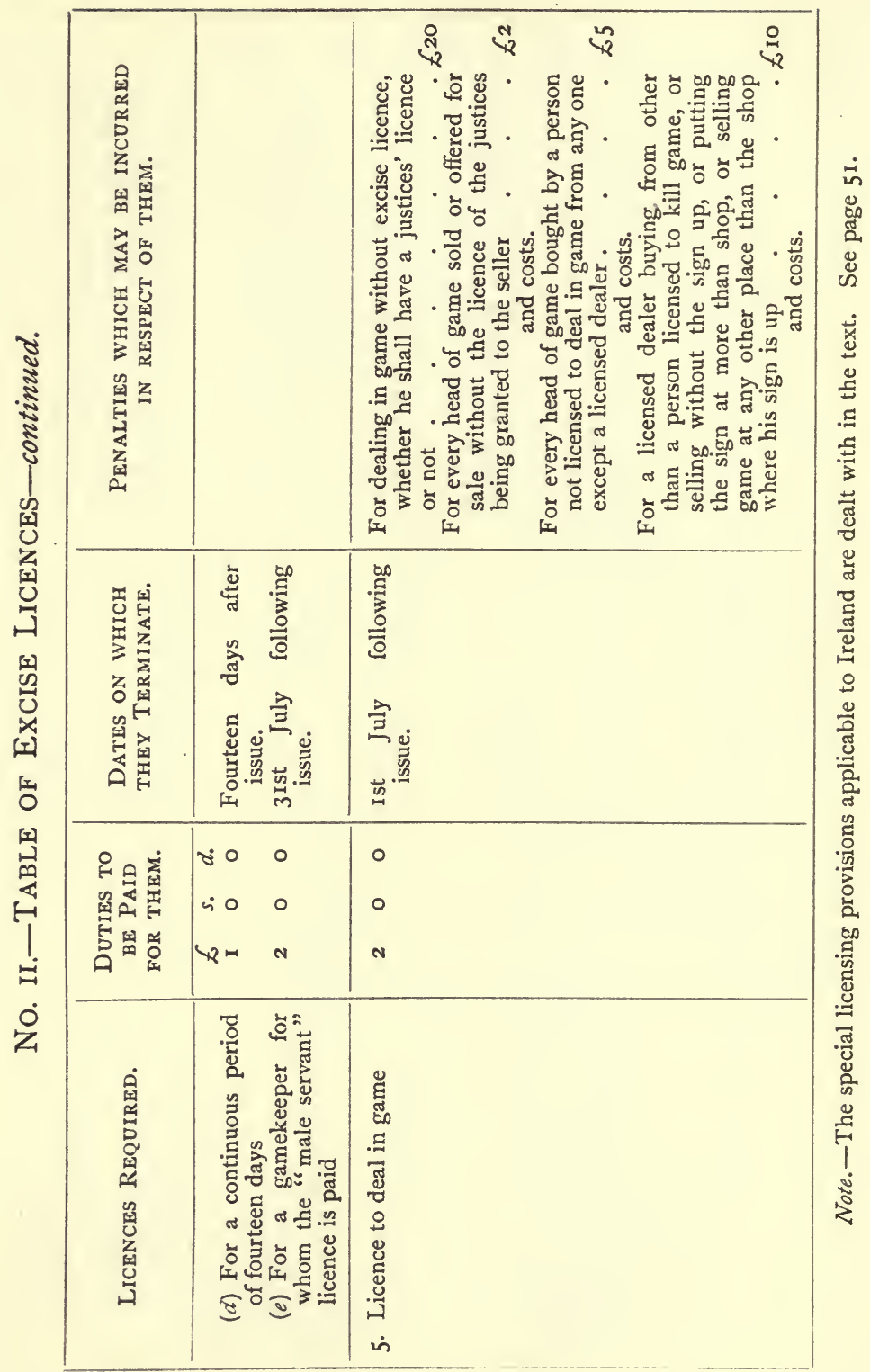


NOTES 
NOTES 


\section{CHAPTER VI}

\section{The Dog-from a Gamekeeper's Point OF VIEW}

By Dr. Charles Reid

Time was when the dog was perhaps of more importance in the field than it is now, when our grandfathers sallied forth at break of day adorned in those quaint and wondrous garments which still excite our admiration, if not our envy, and with his trusty Joe Manton and all the varied paraphernalia deemed necessary accompanying, with, and by no means least, a dog, most probably trained by himself, and from whose prowess and excellence a large measure of his enjoyment was sure to be derived. And in the evening, over his pipe and his home-brewed, did not the mighty deeds of "Don" and "Carlo" figure fully more prominently in the conversation than in these degenerate days? Most of us can recall and picture the satisfaction of Charles St. John, after watching the futile efforts of a brother sportsman on the other side of the river Findhorn trying to retrieve in vain several active "runners" in a turnip-field, when, having crossed the river and politely offered his assistance, he, with the 
aid of his "poodle," brought them to bag. Other men, other ways. Still, the conditions are not so changed that we can get through a day's sport without the assistance of our canine friends, and it is in the hope of bringing the importance of this still more prominently before a very intelligent class of men that we are encouraged to write these few pages. The average sportsman is a tender-hearted man, of sensitive disposition, and nothing mars the day's pleasure more than the feeling that, owing to having inferior dogs, a number of wounded animals have not been picked up ; and if, as probably he will be, a man who shoots a good deal, he cannot help contrasting the result with such and such a place where he has just been shooting, and which, owing to the superior training of his friend's dogs, was the source of much comment and much satisfaction to the various "guns." How often has the present"writer heard in the smoking-room this remark, made too by one who, from his experience, was a capable judge: "I have only known three keepers in my life to whom I could entrust a dog to train for me." This, if true, shows how little the subject is attended to by gamekeepers as a class, and the present writer will sufficiently endorse it by remarking that the attention paid to this subject by gamekeepers as a whole is far below what it ought to be. I do not altogether blame them, but, on the contrary, I believe that owners and shooting tenants are solely responsible for this state of affairs. Not one in ten of shooting men takes any 
interest in this subject, and it has become so common for tenants to depend on getting their dogs from dealers at the beginning of each season, regardless alike of their appearance or their qualifications-in fact, they probably never set eyes on the animals till they, the sportsmen, arrived at their shooting quarters. Still, apart from your peripatetic sportsman, we have a large class who are more interested in their dogs, and who wish to see them not only better looked after, but better trained, who do not wish to have their sensitive feelings disturbed and their sport marred either by the unnecessary loss of wounded birds, or their minds haunted by the frantic yells of "Carlo" under the lash, even though the flagellation was well merited.

Even from a commercial point of view, it is important to consider this question, because the value of game, unnecessarily lost, at the end of the season may represent a total which would have been many times the value or keep of a good dog.

It is part of a good keeper's duties to be able to train a dog both for the moor and the covert, just as well as he can rear pheasants or trap vermin; and yet how many do we find thoroughly proficient in these latter who have the most elementary ideas on the subject of the former? By contrast, and not by any means by way of disparagement, we would point out another class, who, with no better material to work upon, if so good, get on the whole better results. We refer to shepherds and their collies. We hear of the sagacity 
and cleverness of the collie, but feel certain that the great majority of gamekeepers will bear us out when we state that the average sporting dog, pointer, retriever, or spaniel, is capable of a higher education than their much-vaunted canine brother, and that, as a rule, under more adverse conditions. Still, the average collie is better trained than the average sporting dog. The explanation is not far to seek. More work is put on him, and so gradually that his brain can absorb and remember-he is kept up to the mark by having to do certain things daily, and not allowed to forget-he is not taken out on a string half a dozen times a year and expected to do a dozen different things of which he never learnt the rudiments. Many readers may suggest: "But we have not the shepherd's time to do this, with so many other duties." Quite true, but it is not necessary. Much can be done at odd times in the spring before the nesting season, and again in the early autumn before shooting begins. A few lessons during ordinary exercise and at odd times have a wonderful effect, and these, as is a mistake often made, not left till the shooting day, when the excitement caused by the appearance of game and the shooting is sufficient to absorb the dog's whole mind. However, later on we refer to this subject more fully.

\section{Exhibition of Dogs}

It is not necessary in a work of this kind to discuss the vexed question of the influence of canine exhibi- 
tions on the sporting dog. Much good has been done by these, but, alas! much evil. The sporting dog, however, has suffered less than most other breeds, and on the whole, in the writer's opinion, distinct benefit has accrued, except in the case of the spaniel breed. This is due to the fact that these others have not been tampered with to the same extent by "fanciers" as the spaniel has, and the result is seen in the numerous grotesque creatures which appear on the bench, and with considerable difficulty are able to walk a few times round the judge's ring. With these, however, the gamekeeper has nothing to do. The breed is right enough, but by selection a non-sporting class has produced an animal unfitted for work owing to their (the exhibitors) want of knowledge and the apathy of the class who do know. One must remember, however, that those are selected specimens, and that it is possible to find animals of the same breed which are quite fit and able for field work. The majority of our judges of sporting dogs are men who are good sportsmen, and who judge the animals from a working point of view. So also are the majority of the exhibitors of sporting dogs. For this reason the type of our best animals which win on the bench is an improvement on the dog of thirty years ago, and there is undoubtedly greater uniformity. We would advise, therefore, our reader to attend these exhibitions, not to walk round when the dogs are benched, but to make a point of being present at the judging, to plant himself stolidly down 
opposite the ring and to scrutinise carefully every animal in it. If in addition he can get a friend with more knowledge than himself to point out the good and the bad points, he will find that his few hours have not been misspent, and have their own reward in the future, when he comes to select a puppy from a litter to train himself. He will then appreciate what a heavy-loaded shoulder, slack loins, or bad feet mean in a hard day's work. This is by no means learnt in a day, though some persons have an instinctive eye for the points of an animal, and are, like the poet, born, not made. Still, the average gamekeeper is an intelligent man, and given the interest and the fact that this knowledge is going to be useful to him in his profession, he will soon be able to select an animal whose outward appearance at least fits him for the purpose required.

\section{Selection of Dog}

Without going into unnecessary details, perhaps a few of the salient points which occur to the writer may be of service in choosing a sporting dog, whether pointer, setter, or retriever. Suppose you have the choice of a litter of puppies old enough to train, and therefore of an age to enable one to judge what the future animal will develop into-ask the owner to let them all run free in a paddock, and carefully watch their movements. Assuming that the puppies are all in good health, not only do you learn very quickly which is the best mover, but you note also the disposi- 
tion and temperament of the various animals. Look at that bold young scamp, full of life, racing round at the head of the others, chasing every butterfly, leaf, or moving thing, and contrast him with this other timid, nervous creature, afraid of his own shadow. It doesn't require an expert to tell you which will give you most trouble and develop into the better animal. If you find several of the former kind, then so much the better. You can now look over them at close quarters. Let us hope your fancy has a bright, full, intelligent, dark eye. As in the higher animals, including human beings, the eye is a real index of the character. Most judges object to a light yellow eye or a small sunken eye ; and rightly so, because as a general rule you will find the former wild, erratic animals, and the latter dour and stubborn. The head should be big, with plenty of room for brains, and if nicely rounded over the skull proper, preferable to an angular one. The tendency at the present time is to have a long head in all our breeds, but the fallacious and evil part of it is this elongation at the expense of the skull proper. It began with collies, then fox-terriers and Scotch terriers, and has even invaded our sporting breeds. The moment a dog shows some width between the ears, and he naturally gets thicker somewhat as he gets older, then he is supposed by certain breeders to be "past." In the same manner, when he develops some muscle at the sides of his head to use those long jaws, he has become "coarse" and unfit for exhibition. Could anything be 
more absurd? We, however, have something different in our eye-we require all the brains we can get in our dog, and we are going, therefore, to select that puppy with the big head, skull nicely rounded, with a muzzle of moderate proportions, terminating in a nose of good size and open nostrils. Whether retriever or pointer, we want a level mouth, neither undershot nor overshot - the former condition is almost never seen, but the so-called snipey muzzle is a common defect in our retrievers at the present time, and a bad one.

The neck should be of a good length to give "carriage" to the animal, and set on shoulders which slope well back, and the tops of the shoulder-blades should come high up and fairly close together. As in a hunter, you cannot have pace and staying power with the reverse of these.

The chest, looking at it from the front, should be narrow ; but behind the shoulders should be deep from above downwards, and ribs springing well outwards, giving a good "barrel." This should be continued right back to the free or short ribs. If deficient there and great apparent length in the loins, you have a "slack" animal, without endurance.

The loins should therefore be firm, almost slightly arched, with plenty of room from the projecting iliac bones to the root of the tail.

The thighs should be strong and muscular, with hocks well let down-neither "cow-hocked" nor bending outwards and short below. If your dog is to gallop 
freely through heather or jump a fence, as in the case of a retriever, he must be good in his hind quarters.

And the feet, too, are of the first importance. No matter how good he is in the foregoing points, with bad feet he will be a failure. See that those are of a suitable size, compact, toes close, not spreading and arched.

The chief points, therefore, to be desired in a working dog are a good head and eye, light shoulders, strong loins, powerful thighs, and compact feet. Given those in our chosen puppy, and we start well with an animal better than our neighbour's, and we hope to make him above the average in other respects.

\section{Training a Dog}

It would be quite impossible in our limited space to give full instructions on this subject; and, moreover, there exist so many capital treatises on this subject that it is unnecessary. In our opinion, therefore, it will serve a more useful purpose to point out some of the errors which many trainers make in the training of their dogs, and, if possible, to suggest the remedy. At this stage, we would like to recall to any novice the importance of an aid of great value in the hands of our grandfathers, and which unfortunately, in our opinion, has fallen into disuse. We refer to the use of the check-cord. By its means the most refractory puppy can be brought to reason in a third of the time and with a minimum of labour, and certainly with greater comfort to the pupil and his master. We shall refer to this again. 
"Down" and "Down Charge."-It does seem a simple matter to put a dog down and to keep him there, but in actual practice what do we find? Not one in ten will do so and remain there till they are ordered otherwise. In the old muzzle-loading days, of course, it was absolutely essential to give the guns time to reload, and, in our opinion, should be strictly enforced, particularly in the case of pointer or setter. In training any dog, including retrievers, by teaching them this habit early, you obtain a command early of the animal which makes succeeding lessons infinitely more simple. Begin by putting the puppy down at your feet, gradually increasing the distance; if he moves take him back to the same spot. You may move about, keeping your eye on him at first tillyou are able to goany distance without movement on his part. On no account must the dog be allowed to move till he gets a command either by "signal or call."

The value of this lesson is appreciated when the dog is taken first among game. The trainer must be consistent, and what is at first very irksome to your excitable and high-couraged youngster in a very short time becomes a mechanical habit. Sometimes you will have difficulty with a timid, nervous puppy in preventing him from running into your feet. In such a case avoid any punishment, but patiently return him to the original spot. If he persists and you punish him, then he probably bolts. Rather than punish, try the cord and hitch it round a peg or post, so that when he moves a pull in the other direction will show him what you wish. 
From this to "Down charge" becomes a very easy step indeed, again remembering that he is not to be allowed to move till commanded by signal or "call." The advantage of firing some caps or small charges during this early training is twofold : you decrease the risk of causing gun shyness and you avoid the excitement which it causes in the presence of game. In our opinion a very common mistake is to take a young dog to the second part of his education before the first is complete and endeavour to teach those primary lessons in the field. This is undoubtedly wrong, and renders the task a difficult one, which is otherwise so simple. The advantages of having a dog which drops to hand or "shot" in the field are sufficiently obvious. In practice what do we usually find? "Duke " or "Don," if he does "down charge," does so only for a moment, and then he is off to have a look at a dead bird, putting up some others on the way, or the repeated shouts of his trainer effectually does this. In extreme cases we perhaps have a race between master and dog who is to get the bird first, and if Don wins the feathers begin to fly.

Use of "Call" or "Whistle."-We cannot too strongly impress also the proper use of a suitable call instead of the human voice. It is too heart-breaking for words to find a whole hillside cleared of grouse, covey after covey of grouse responding to the frantic shouts of "Don," "Don," "Heel," "Heel," or to witness a fine "show" of partridges, which you have 
with infinite labour driven into the "roots," "clearing" out in all haste at the end. Even more marked is the result of the human voice in snipe-shooting. A dog readily answers, and once he knows its use, if he fails to respond to a second call, a little gentle reminder is necessary. The two most common mistakes made are the too frequent use of the call, which causes negligence on the dog's part; and, secondly, failure to moderate the volume according to the distance between master and pupil. Naturally, if the sound is used to its full extent when the animal is a few yards off, it does not impress the animal when he is at a distance, perhaps, of one hundred yards. The most successful trainers of dogs which we have met were very quiet in their manner, and used signs as much as possible-only resorting to the call when impossible to attract the dog's attention by hand.

Range.-Most young dogs will run out freely, and if not, then the example of an old dog will soon be followed. Where many err is in allowing the dog at first to pursue his erratic course, and allow him to believe that he is hunting for his own amusement, and not yours. Make a point of starting the dog to range to one side or other, and see that he does it. For some reason or other, many dogs will run a short distance and then turn sharp to the other side, thereby missing a particular piece of ground which you wish him to take. Call him up at once, and see that he does what you wish. In the same way get him into the habit of 
mechanically crossing his ground thoroughly, and later, when he increases in wisdom, you may permit him more freedom of judgment. Neither is it good to allow your dog to be working half a mile away, either on the beat below you or the one above which you intend to take next. By teaching the proper "range" thoroughly at first you avoid this, nor do you find him at the far end of a field of "roots" before you have hardly entered. The nature of the work required will determine the requisite training: you require a more bold and freerunning dog for a moor, where birds are few and far between, than for a well-stocked moor or on low ground, where you are working in enclosures. For this reason your training will be different on a well-stocked moor on the mainland, from what it would be if moor shooting were on the western islands.

Pointing.-As a rule this is not a difficult matter to teach-most puppies will stand on scenting game, and the example of an old dog may be useful. Here the use of the check-cord is of the greatest value, for it enables you to steady him for any length of time you wish and effectually prevent chasing birds when they rise, rendering excessive punishment unnecessary. A good plan is to find your birds with an old steady dog, which the young one is quick to observe, then with the end of the cord in your hand you "steady" him also for a few minutes-the chances are that he also gets their scent, then flush your birds, putting both dogs " down," and carefully mark them down. Now take up the old 
dog, go to the place where you know they are, and allow the young one to find them, taking care that the end of the cord is within reach. Whenever he winds them, then repeat "Steady" or "To ho," and repeat the previous performance. Having done this, the rest is easy. Two lessons of this kind are often sufficient, and, assuming that this has been done in the spring, when birds sit so well before the nesting season, it will only require a few points before the Twelfth to produce a dog that is fit to take his turn with the others. The only precaution necessary is not to run him too long and too much. No man can have really good dogs who keeps them going when they are tired-nothing spoils his ranging sooner. When on this subject we would again point out the importance of thoroughly teaching his dog those preliminary lessons before he is taken to game. Very little of the latter is necessary before he is fit to be shot over-much less than most persons imagine. Many owners and tenants of shootings refuse to allow their keepers to train dogs on their ground, in the belief that it disturbs and injures their sport. That it does so undoubtedly if a brace, perhaps, of well-grown lively puppies are taken on to a moor and allowed to career wildly after every moving object, but knowing as we do, and have tried now to show, that so little is necessary if the greater part of the training is done, as it should be, before they see game, we think that keepers should be allowed considerably more latitude in this respect, and the benefits to the owner in having better dogs 
would be the immediate result, with a handsome addition to his servant's yearly income.

"Heel."-It is also unnecessary to give instructions how to keep a dog to heel, but again in practice how unsatisfactory is the observance of this simple rule! As we have already pointed out in the abuse of the "call," the constant repetition produces neglect to obey. The dog is called to "heel," which he obeys, perhaps, for thirty seconds, till he finds something attractive to his eyes, or more frequently his nose-he is allowed to do this with impunity till a little more confidence and freedom on his part attracts attention, and he is again called to "heel." Few things are more irritating to good sportsmen who understand the "game" than the misuse of "heel " and the abuse of the "whistle"; and if the user is armed with one of those instruments usually seen in the hands of our friend "Robert," then good-bye to a pleasant day's sport. And yet the remedy is so simple, viz. a little suitable reminder, or, in the case of a shy, timid dog, the use of the check-cord till the habit is fixed. Again, the importance of this it is almost unnecessary to point out, for how often does not the necessity of keeping to " heel " arise in a day's sport either to save the dog himself unnecessary work or for the welfare of the sport itself.

Running in to "Shot." - Of all errors in the training of our dog this is the most common, and probably the worst. Unfortunately, too, when once become a confirmed habit, it is almost impossible to remedy. Of 6 
course in the case of a "setting" dog it is not usually so marked, because, unless he has been taught to retrieve, he rarely bolts in at once on his game, but, even in the case of a setter, it may mean a diminished bag through flushing other birds before the guns have reloaded. By insisting on the "down charge," as we have already pointed out, we find the prevention, and the sole cause is the want of consistency on the part of the trainer. On no account should the dog be allowed to move without word of command, and if he does, then let him be punished more or less severely according to the particular temperament of the animal. The punishment may only be a verbal reproof or something more tangible, but escape one or other he must not. Here, again, the check-cord is of great value, and if a dog is interrupted when half-way to his game, the effect is more salutary than a dozen severe thrashings.

Over-training.-Occasionally one sees a retriever trained most thoroughly, who does everything he is commanded perfectly, and yet he is of small value at work. Why? Because he is a machine-the dog has no confidence in himself. If put on to find a bird, he gives in at once and returns to heel; or the moment he loses the scent he looks to his master for guidance. This is pure habit, of course. Had the dog been allowed to use his own judgment-i.e. had his master, even though he knew the dog was wrong, allowed him to find out this for himself a few times, he would have produced a better dog. 
Use of Eyes instead of Nose.-Also a common error made by many. To save trouble, or, it may be, from delight in seeing the young dog carry so well, he is allowed to retrieve what he sees-he does this, perhaps, thirty times for once that he is asked to find something which he hasn't seen fall, or, worse still, is in his view all the time. Should one be astonished, therefore, that his first idea is to use his eyes, and continue to do so while that cock pheasant is making tracks for the next country, or that winged partridge had made a dozen sharp doubles in the rank turnips? Had he used his nose at first, he ought to have had that bird in twenty yards instead of delaying the guns for ten minutes or more, probably losing his game altogether. Another common fault is in allowing a young dog to run too far out to retrieve his game- he sees the bird fall, and is allowed to go; in many cases he overruns the spot in his keenness. To remedy this he ought to be taken near the place and given the advantage of the wind before he is told to "seek dead." All this should be done quietly, and if too impulsive, he should be cautioned with the word "Steady." Undoubtedly some dogs are from the first better than others at marking birds down, but the chief fault lies more with the trainer in not inculcating this habit of "seeking close" at first till he strikes the trail, and then giving him a chance of doing the rest himself. The less the young retriever sees of "fur" at first the better; indeed, many good trainers refuse to allow their dogs to touch hares or rabbits for 
at least two seasons, and the practice has much to commend it. Probably one sees better-trained retrievers at covert shoots than elsewhere, because unless he is a wise man the owner does not produce his worst on these occasions, and possibly the temptation to run riot is not so great. To make a reallygood retriever requires much more time and patience than either pointer or setter. Begin early, but be careful not to put so much work on the animal as to produce the effect such as I have already alluded to under "Over-training."

Temperament.-To be really successful with his dogs, the trainer ought to study their character as he would a human being. Like the "higher animal," he has his peculiarities, which must be recognised, otherwise a half-trained animal, or even failure, will be the result. How often do we hear that So-and-so is a "good man," but very severe with his dogs? In every litter you will find no two alike, and to mete out the same treatment to all spells failure at once. The trainer who recognises this early saves himself an incalculable amount of trouble and produces better animals.

\section{Choice of Particular Breed}

It is unnecessary to give advice as to a choice of a particular breed. Owners of pointers advance many reasons on behalf of their favourites as against the various breeds of setter, while the owners of the latter are equally strong on the other side. While it may be that on an exceptionally dry moor the shorter-coated 
animal has a slight advantage, we do not think that this is of great importance, and fancy is allowed to determine the preference. For similar reasons a decision is made between the curly and the heavy-coated retrievers, and between the various breeds of spaniel.

Of much greater importance is to satisfy oneself that the particular animal springs from a good kind, and that from his structure is fitted for the work required. There is no reason why a dog should not both be good-looking and a good worker. Many of our best dogs on the bench are capital workers, and it is pure ignorance on the part of those who hold that the whole of our exhibition dogs are useless for sporting purposes.

Assistance can be got from Books. - The great body of our gamekeepers are intelligent men, and thoroughly capable of understanding what is written on this subject, and they have scope in the numerous and inexpensive books published on dogs and their training. Unfortunately, the majority are content to follow in the footsteps of the "head" with whom they served their apprenticeship, who, however capable he was in conducting a grouse drive or rearing pheasants, had neglected this branch of his trade. This is not as it should be, and we would again impress on every keeper who takes a pride in his work the necessity and the advantages of being "a good man with dogs." We would advise him to study works such as Dog Breaking, by General Hutchison, or Training of Retrievers, by Colonel Henry Smith, and not merely to rest 
content to teach a dog obedience, but by patience and perseverance to develop to its utmost the natural intelligence of the animal. His experience in course of time will tell him that some of his protégés will not be capable of attaining a high level, but he will meet with others which respond to all his care, and in developing whose good qualities the trainer will feel that he has had a well-merited return apart from the many encomiums bestowed by his confrères.

\section{The More Common Ailments of Dogs}

We have not space to treat this subject as fully as its importance would justify, but probably if we mention the more common ailments met with in the dog, and capable of being intelligently treated by the average gamekeeper, our purpose will best be served. In this category we include such diseases as Distemper, Dyspepsia, Rickets, Chorea or St. Vitus' Dance, Fits, Paralysis, Mange, Disorders of Kidneys, Heart Disease, Dropsy, Congestion of Brain, Constipation, Diarrhœa, etc.

It may be more convenient at this period to give some remarks on the ailments of puppyhood, which, as a rule, are simple and not numerous. Many a good puppy is lost from want of a little care. Occasionally it happens that a puppy is born "tongue-tacked," and unable to suck properly, which is only remedied by a "snip" with sharp scissors. The writer also has known a whole litter lost within a week of birth owing to the 
teats of the dams being so enlarged that the puppies could not get suitable nourishment. This would be likely to happen only in the case of the dam that had previously several litters; but if she brought other litters up successfully, on this occasion the true cause might be more easily missed. The remedy was easily found on a future occasion by providing a foster-mother.

Constipation at this early stage sometimes gives trouble, for which a little castor oil is advisable, and it is good practice at any time during this period to do so whenever a puppy is seen to be restless, whining, or not sucking with the others. The common mistake made is doing so when too late. The use of an enema syringe, even the small glass ear-syringe, with soapy warm water, may be found of great value in an urgent case.

Your intelligent and careful keeper will prevent the ordinary ailments of puppyhood better by attention to the dam before their birth, and we would specially point out the advisability of allowing the dam to run about during at least two weeks before the expected arrival of the litter. If asked, however, to what the excessive mortality in puppyhood is due, we would unhesitatingly say worms. Here, again, prevention is better than cure. See that the dam is treated for worms before impregnation; and also recollect that vermin may be the means of introducing these pests, for it has recently been proved conclusively that the "flea" acts as a host during an intermediate stage of the development of the 
parasite, and it is obvious how both the dam and the puppies can be thus infected. It may be advisable to wait till the puppies are weaned before treating for these, but if necessary, treatment should not be delayed. The most common worm at this period is the "round" worm, pointed at both ends, whose habitat is the stomach and small intestine. Their presence may be noted in the vomit, or later in the fæces, and it is safe to assume that they are present if the puppy is dry in his coat, more or less emaciated, with abdomen overdistended, or accompanied in an extreme case with fits. Santonin is the remedy, given fasting, in doses of $\frac{1}{2}$, I, or 2 grains, according to age and size of puppy. An equal amount of calomel seems to increase the action of the drug, or followed by a small dose of castor oil. If necessary, this should be repeated in a few days.

Rickets is also another common ailment of puppyhood, caused by errors usually in diet, and, secondarily, insanitary or unsuitable surroundings. From our experience the former is the usual cause, i.e. the food is given in too large quantities and seldom, instead of small and often. A puppy after weaning ought to be fed at least four times a day till he is three, or even four months old, and thrice daily till six months. Milk should form the chief portion, and the solids increased with his age. If skim milk can only be used, then the fat must be replaced by the addition of cod-liver oil or other fat ; and where size is of importance, as in most sporting dogs, great benefit will be derived by the 
addition of a preparation of hypophosphates, such as the popular Parrish's syrup or Chemical food. We would here emphasise the importance of using new milk as much as possible ; no other article of diet can replace it if you wish to do justice to your puppies. The starchy foods, meat, potatoes, etc., may be introduced gradually, but very sparingly at first. Under the secondary cause of rickets we would include a damp or cold bed, want of exercise, etc., and though many breeders consider these as the cause of rickets, still, in our opinion, the primary cause is to be found in errors in diet such as we have mentioned, and these last are often contributory. In many otherwise capital kennels the arrangements for the rearing of puppies are too often defective, and if the owner can possibly manage, we advise him to send them out to "walk" at a farmhouse or with a cottager who possesses a cow. At the critical period -between the second and fourth months-the keeper can inspect the puppies every fortnight at least, and remedy any faults in overfeeding, etc. Where possible, also, board them out in pairs for the sake of the additional exercise which they get in playing with each other.

Distemper is the greatest scourge of the canine world, and, unfortunately, the treatment is also far from what it should be. Again, space will not allow us here to go fully into this matter. As in most things where you find such a difference of opinion, the probability is that the right one is still to be discovered. Vaccination 
with calf lymph has had many advocates, but the balance of opinion is against it being of any value, though we still live in hope that a serum will be found which will do for distemper what antitoxin now does for diphtheria. We would here point out to keepers that distemper is a specific fever caused by the presence of a poison in the system, that the symptoms vary according to the virulence of the epidemic and the particular animal affected-that, therefore, to treat the patient intelligently, one must not pin one's faith to So-and-so's ball or powder, but rather skilfully prescribe for each step of the disorder. When the animal is first affected it is good treatment to give a dose of opening medicine, but not a severe purgative; to feed often with light, sloppy food, chiefly of milk or broth. For medicine, half to one tablespoonful of spirit of mindererus twice or thrice daily, and even more often if fever is high. If powder is preferred, then 5 to 10 grains of nitrate of potash may be given at several intervals. In the majority of cases this is sufficient, and a recovery takes place. If cough is troublesome, or the animal is "wheezy," 5 to Io drops of ipecacuanha wine may be added to the mindererus spirit. In bad forms you may get head symptoms early, when the dog becomes restless, even delirious, and to treat this you may give 10 to 30 grains of bromide alone or with tinct. of hyoscyamus, Io to 30 minims. Pneumonia is, however, the usual complication in fatal cases, occurring, too, most frequently after the acute symptoms have subsided. The ignorant 
owner thinks that a walk would do the animal good, or even a wash, and the result is disastrous. Prevention here again is the first essential, but if the presence of such a complication is recognised by the rapid and laboured breathing, then apply hot fomentationsremembering, too, that the animal usually lies on the affected side-mustard and whisky; turpentine sprinkled on the hot cloths may be applied, and if necessary, when the case demands, don't hesitate to remove the hair over that side before applying the counter-irritants. Whatever doubt one may have about giving stimulants at the onset of an ordinary pneumonia, there can be none in this form, and we would give it freely,-whisky, port, beef-tea, eggs, etc., in small quantities and at regular intervals. For medicine, strychnia, carbonate of ammonia, etc., have great value, but the former should only be given under skilled advice.

Chorea, or St. Vitus' Dance, is a very common sequel to distemper, and much more intractable than in human beings. When the spasmodic, jerking movements occur during the attack, bromide of potash, in doses already referred to, would be useful, and recently salicylate of soda in Io-grain doses, with twice the amount of bicarbonate of soda, has been found valuable. This should be given three or four times daily, and the dose gradually increased. Iron and arsenic later as a tonic and the latter alone pushed may cure. Fowler's solution in doses of $2-10 \mathrm{~m}$. is given twice daily and 
increased till it causes redness of eyes or symptoms of irritation of the alimentary tract, such as vomiting, diarrhœa, etc.

For Fits or Convulsions occurring in distemper, the treatment already given above under distemper will suffice, and, indeed, in all cases where the cause is not known. The keeper will remember that these are only symptoms, not necessarily an organic disease, and to treat intelligently he will try to find what is causing them, remembering that worms are a very common cause. Again, if the fit occurs soon after a meal in a dog of gross appetite, the treatment is obvious. If in an old dog, and if he has noticed blindness on one side, he may suspect some pressure on brain from tumour or other cause. Therefore, find the cause, if possible. Bromide of potash again will be valuable, and may be combined with iodide of potash.

It is unnecessary to go fully into diseases of the heart, kidneys, etc., which really belongs more to the veterinary surgeon. A simple diuretic, such as mindererus spirit or nitre, is useful in relieving kidney irritation such as dogs often suffer from after hard work.

Mange. - This malady is far too common in most kennels, especially when one knows that it is preventible. The so-called red or virulent form is equally easy to check if treated at once, though equally difficult later, and we have found the various mercurial ointments the most efficacious. The green oxide of mercury 
ointment, one part to two of lard, when applied daily on the appearance of the patch of mange, generally cures, and a dressing of sulphur and oil, followed by a good washing with carbolic or Jeye's fluid properly diluted, generally effects a cure. Paraffin oil is also very valuable, but should be diluted with oil or an emulsion made with soft soap.

Eczema.-Forpatches there is nobetter remedy than white precipitate ointment, which may be diluted with an equal part of zinc ointment. If dry and scaly and more chronic, some tarry preparations may be added. The food also should be changed, more vegetables given, and Fowler's solution tried in obstinate cases.

Rheumatism.-Thesalicylatesare now sowell known in the treatment of this complaint, that every keeper ought to be able to administer them at once. The salicylate of soda is perhaps the most easily procurable and the most easily administered, both horses and dogs taking it in their food. From 5 to 5 grains twice daily, or every four hours in acute cases, will work like a charm. In more obstinate cases, 5 to Io grains of the iodide of potash given twice daily for some weeks is also good treatment. Milk should also form a considerable proportion of the diet, and mild occasional doses of aperient medicine.

Wounds. - A keeper ought to be able to sew up wounds when necessary, and the addition of a few surgical needles, with ligature silk, horsehair, or stout fishing gut will often come in useful. He should, of 
course, wash the wound thoroughly with a weak solution of carbolic, Condy's fluid, or other antiseptic, and muzzle the animal to prevent him tearing open the wound.

Eyes.-Inflammation of eyes can easily be treated satisfactorily at the outset with weak lotions of boracic acid or alum-just sufficient to make it perceptible to one's own taste. For more chronic cases, of yellow oxide of mercury two grains to an ounce of simple ointment-a small piece of the size of a pea rubbed along the eyelids - is valuable. Here also the strength of the ointment may be increased considerably if found necessary.

Kennels. - Most of the diseases from which our dogs suffer are preventible, and bad damp kennels are responsible for as many of the diseases as the negligence of the keeper. It is difficult to determine whether to pay the keeper for feeding the dogs by the week (two shillings per week per dog being considered a fair price), or simply to order in for him a stock of feeding stuffs. In the latter case the dogs are generally sure of getting the feeding, while in the former case a keeper often tries to make profit off the dogs, and we have known instances of starving and improper feeding. Wooden floors which one sometimes sees in kennels for the purpose of preventing rheumatism are an abomination; they are very difficult to keep clean. The ideal kennel to our mind is one of which we give a plan and dimensions by Alex. Cairns, architect, Hope 
Street, Glasgow, and can be seen at Glenreasdell, Argyll, by any one. The kennels face south, and alongside of them stands the keeper's house. The building is surrounded by a wire fence $7 \mathrm{ft}$. high, covered with 3 in. mesh wire netting, enclosing a small park of 3 acres, where the dogs can have exercise, and into which they are turned when the kennels are being cleaned. A burn also runs through this enclosure, where they can bathe in warm weather. This, to our mind, is an ideal situation.

Iron roofs should not be used for kennels, as they are extremely hot in summer, and insufferably cold in winter. Where they at present exist, it is a good plan to cover them with sods of grass, which in time grow together ; such a covering, with a little top dressing, will last for ten or fifteen years, and will keep the kennels cool in summer and warm in winter.

It will be seen in the plan that the kennels are built on stone piers $2 \mathrm{ft}$. off the ground. On these piers are laid old iron rails, and transversely placed are a number of old iron rods; any suitable scrap iron will do equally well to hold the cement. Under the iron beams erect a temporary support of wood on which to lay the first coat of cement, which should consist of three parts of broken brick or stones to one part of cement of first-class quality, give a gentle slope of 2 or 3 in. to the front, when hard, finish smooth with two of sharp sand to one of cement. 
The walls are built of stone or brick and rough cast, and when the floor is thoroughly set, the wooden supports should be removed. It will be noticed that underneath the floor is a very large space which is useful for storing pheasant coops, coals, or anything that requires to be kept dry and out of the way. The back part is fitted with divisions for a bothy, and store-room or boiler-house for the preparation of the dogs' food. A brick wall divides the sleeping accommodation for the dogs. The walls are cemented flat and the sleeping bench is of wood 20 in. off the ground. A two-inch board is placed as a ledge, covered with strap iron to prevent the dogs biting it. The doors into the run, instead of having the usual shutter, have an opening 26 in. by I I in. wide, 6 in. from ground. Close-fitting swing doors are hung on these by two small pivots at the top sides, so that the dogs going out and in have only to push their head against the shutter, walk through, and it swings back into place. The dogs soon get accustomed to this, and the door being always shut prevents draughts, ventilation coming in through the eaves of the house. The walls of the run should be of flat cement, and should not be over $2 \frac{1}{2} \mathrm{ft}$. high, a cement cope of $6 \mathrm{in}$. on which the railings, of $5 \mathrm{ft}$., are set, makes a total height of about $8 \mathrm{ft}$. The object of the low walls is to allow the sunshine and air to dry the run after washing. The old-fashioned high walls, meant for shelter, act as a shade, and prevent entrance of sunshine, the walls become green and 
mouldy, and the dogs contract rheumatism. If it is too cold for the dogs to be outside, they can get shelter inside. It will be noticed the fireplace in store and bothy is against the centre dividing wall and gives heat to two of the dog houses, which are useful to place sick dogs in. Poles 18 in. high and 4 in. in diameter near the gutter should be fixed in the floor of each run for dogs to lift their leg against. The gutter drained to the lowest end should run the whole length of the kennels, with an outlet pipe which falls into a tank or cesspool with two divisions, the second of which is filled with coke to act as a septic tank. From the top of the second chamber a small fireclay pipe will run to take the water away, and will discharge itself at some distance into the ground, which can be improved by a few carts of gravel. This will form a second filter for the water before it enters the stream, and will keep the outside of the kennels clean and dry. Water should always be led into the kennels. On each run there should be a wooden platform or bench 8 in. off ground for dogs to sit out on.

A very good plan to stop dogs from the bad habit of wetting their bed is to have a folding lid of light spars shutting down about I 7 above the bench according to size of dog, so that there will be just room for dogs to get in, but not space enough to stand up in. If this is done dogs will not be able to continue the bad habit. 


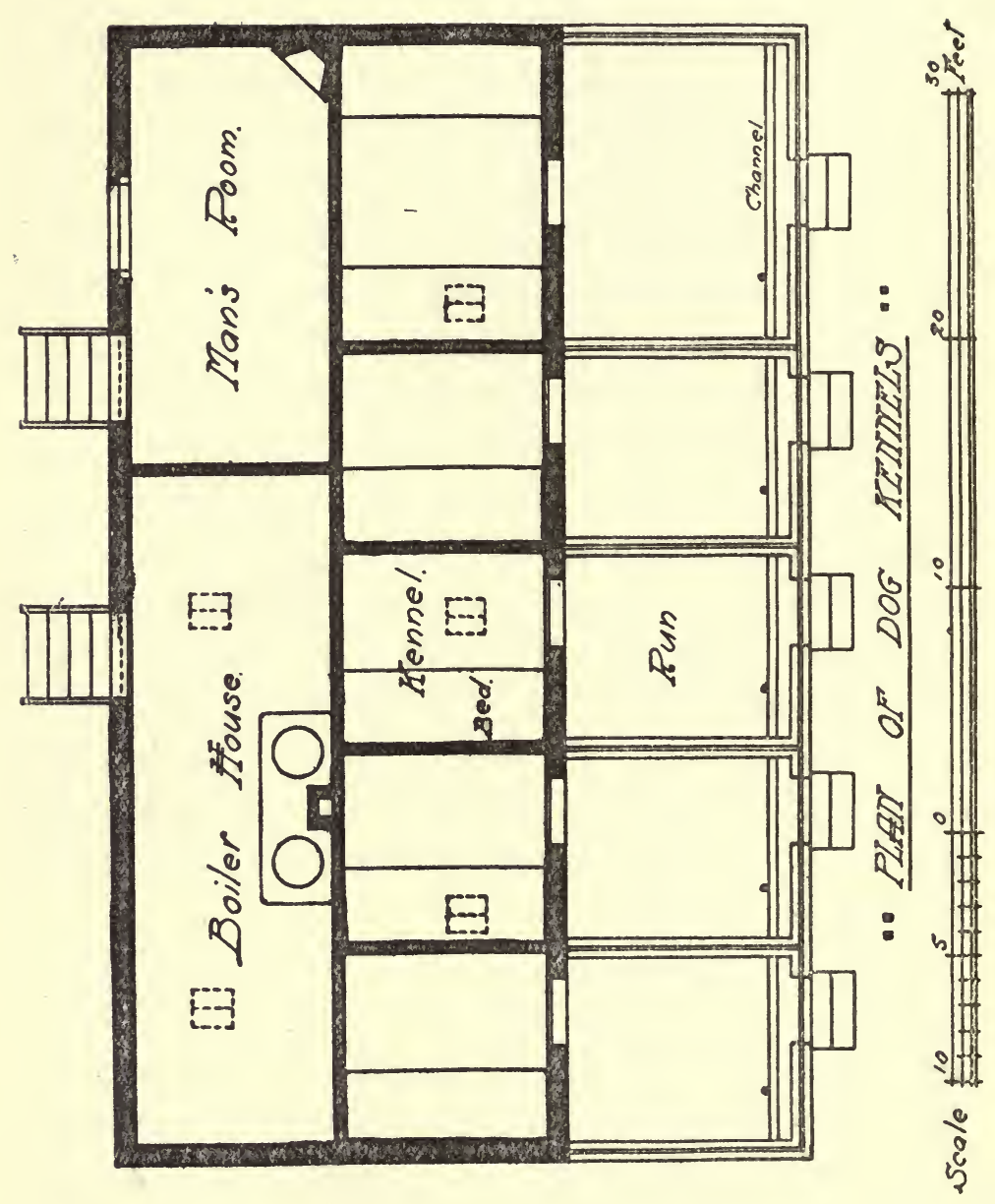




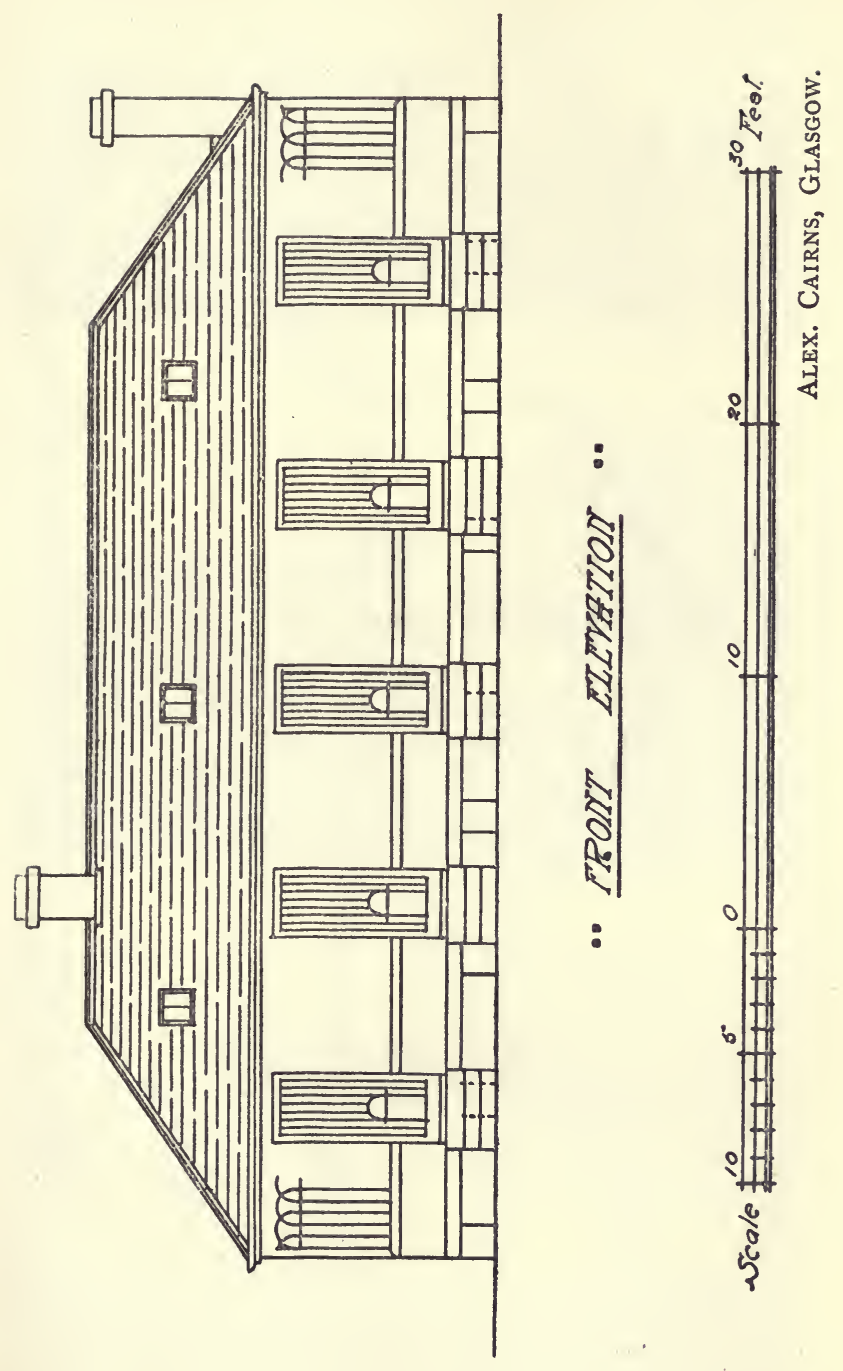



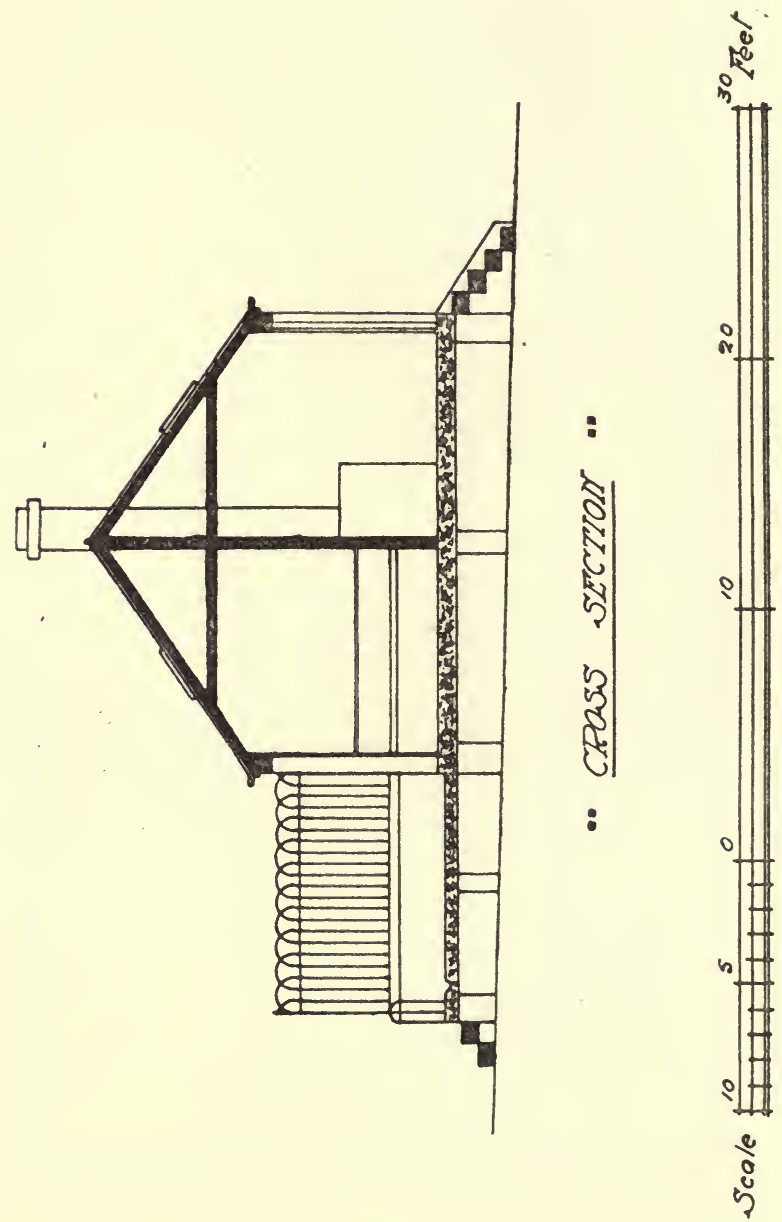


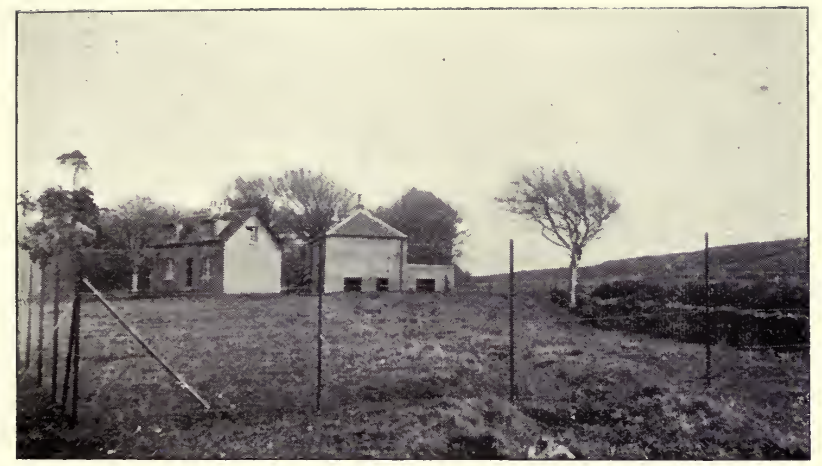

KEEPER'S HOUSE AND KENNELS.

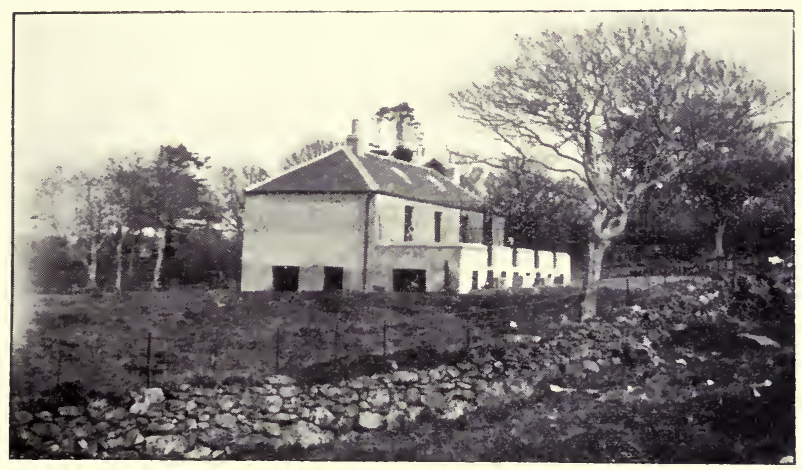

GLENREASDELL KENNELS.

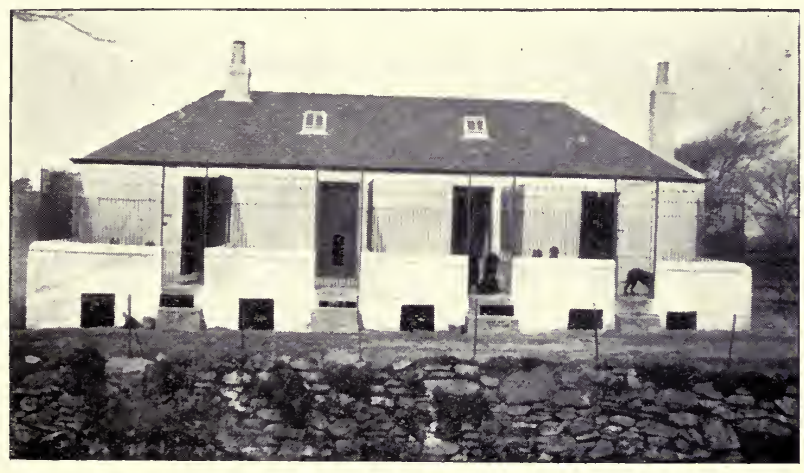

KENNELS, SOUTH VIEW. 

NOTES 


\section{NOTES}




\section{CHAPTER VII}

\section{VERMIN}

By ToM Speedy

THE first essential condition in order to increase a stock of game on an estate is the destruction of vermin. As soon as game begin to increase, vermin will arrive upon the scene, although how and from what quarter they have introduced themselves are among those mysteries in natural history which are as yet unexplained. As bearing somewhat on the subject, it may be mentioned that in a recent visitation of a plague of voles, when these rodents threatened to devastate the pasture-lands in the Border counties, a foreign owl, the short-eared species, which, though an occasional winter visitant to this country, has only on rare occasions been previously known to breed with us in any numbers, congregated in hundreds in the vole-invested districts and nested in the heather. Whence they came in such numbers must ever remain a mystery, but there they suddenly appeared. I have noted a similar coincidence with regard to game. I have introduced hares to an island, where they at first rapidly increased. The eagle and the buzzard soon made their appearance, and nested on the island, when 
the hares vanished at an alarming rate. It must therefore be manifest that a fundamental principle in gamepreserving is, that a sharp eye be kept on the destruction of vermin.

There are few things more interesting than the trapping of vermin, and no keeper will prove very successful in this task unless he makes a careful study of the object of his pursuit. By keeping a diary in which to note carefully the kinds of vermin got, and by duly recording the contents of their stomach, or crop and gizzard, the young keeper will, with a few years' experience, possess an amount of knowledge which will give him power among his fellows. So much nonsense is written on this subject, that, without practical acquaintance with the habits of the various kinds of vermin, he may be very easily led astray by non-practical writers promulgating their fanciful theories. When man first appeared on the scene there, was, presumably, what some are pleased to call the "balance of nature." Man, however, was given dominion over the beasts of the field and over the fowls of the air; and by gradually destroying those which were useless and those which preyed on others which were useful to him, a somewhat different state of things was by-and-by arrived at. A few hundred years ago, wolves, foxes, and other vermin were so plentiful in this country that sheep-farming was out of the question. By killing down the wolves and other large beasts of prey, sheep-farming became so far a success. It was found, however, that a similar 
crusade had to be waged against birds as well as against beasts of prey. Sir William Jardine, in his "Naturalists' Library," tells us regarding eagles: "Such was the depredation committed among the flocks during the season of lambing that every device was employed and expense incurred by rewards for their destruction. From March I831 to March I834, in the county of Sutherland alone, I7 I old birds with 53 young and eggs were destroyed."

Now that sheep-farming hardly pays and grouse have become so valuable, it is necessary to cultivate the latter by destroying their natural enemies, in the same manner as it was necessary to destroy the wolves, etc., for the sake of the sheep. Of ground vermin we have the badger, otter, fox, pole-cat, stoat, weasel, hedgehog, and rat. Among winged vermin we have the hawk species, from the eagle down to the merlin. The gamepreserver has chiefly to guard against the peregrine falcon, the sparrow-hawk, and the merlin; also the corvidæ-ravens, carrion-crows, and magpies. There are others which do very considerable destruction to game, but not invariably so. Amongst these may be mentioned rooks, jays, jackdaws, kestrels, and owls.

It is with a feeling of regret that I classify the badger with vermin. Being brought up in the historic Border land, and inheriting the hunting spirit of my ancestors, I in my boyhood regarded badger, fox, and otter hunting as the chief end of man. Badger hunts on the banks of the lower reaches of the ' $T$ weed are still to 
me a pleasing remembrance. Of late years the badger has in many places disappeared, in consequence of the common use of the steel trap. Many gentlemen, however, and notably the Earl of Rosebery, are preserving them, and have reintroduced them on their estates, so that it is to be hoped the day is yet far distant when the extermination of this, the largest, strongest, and fiercest of our British wild beasts, will have to be deplored.

Theravages of the badgeramong gameare generally confined to the devouring of eggs and the digging out of rabbits' nests. Their scenting power is remarkable, as they dig down perpendicularly to a depth of 3 feet straight into the nest. I was recently interested in an illustration of their scenting powers by poison being inserted in a dead hind calf, and placed on an island in the centre of a deer forest for the purpose of destroying carrion-crows. The water round the island was deep and 20 yards across, yet the badger had scented the carrion, and swam over to its certain doom. This is the only illustration of badgers swimming that has come under my observation. They are very destructive among eggs, and as a consequence their presence cannot be tolerated in a game-preserve. I have frequently trapped them with eggs as a bait, though they are practically omnivorous, wheat in harvest-time being found in their excrements, but they are likewise attracted by any sort of carrion.

The otter may also be classified as a poacher. It is generally believed that he preys only upon fish, but 
instances have come under my observation of his killing rabbits and grouse, especially the former, which fact can be corroborated by an examination of the excrements.

But a much more dreaded enemy of the gamepreserver than either the badger or the otter is the fox, -though here one must speak with bated breath, foxhunting being regarded as the national sport. In hunting districts the fox lives the life of a licensed freebooter, feasted on the best, from the farmer's geese and turkeys and all kinds of winged and ground game down to the smallest of birds, and protected even by the "ruthless" gamekeeper. It is vastly otherwise where no foxhounds are kept; yet even there, despite the co-operation of farmers, gamekeepers, and shepherds, he holds his own against his numerous enemies, among the barren waste lands of our Scottish mountains. Notwithstanding every device employed, the fox is still to be found in great numbers in the Highlands of Scotland, many cubs being dug out and sent to hunting districts every year. When a den is found containing cubs the usual method employed is to bolt them with terriers and then shoot them down like rabbits. Frequently, however, cubs find their way into crevices in the rocks where they cannot be followed by terriers. Keepers conceal themselves in different places and wait till the old ones approach with food for their progeny. As it is the invariable habit of the fox to approach from leeward, and as his scenting powers are so keen, it is difficult to take 
up a position. The love of foxes for their offspring, however, is so great that they run great risk to reach them, and in avoiding one keeper when approaching the den, they frequently go within range of another, and are shot. I have, when watching a cairn, known the vixen steal in unobserved and remove the cubsunder cloud of night, when she must have passed within a few yards of where I lay. On one occasion she appeared on an eminence above me, and seeing her outline distinctly against the sky, I fired with fatal effect, though she ran a considerable distance before dropping dead. The piteous howling of the dog fox all through that night is still fresh in my mind, and indicates a love of offspring which might be an example to higher animals.

In such circumstances, and where the nature of the den or cairn admits, the cubs can be caught in traps. It is a common method to do this, and as fox cubs are in many cases a considerable source of income to the keeper, I would recommend that Cruickshank's patent rubber-jawed trap be used, in order to prevent the legs being broken. Any lady can put her hand on the plate and spring the trap without injury. Of course, the keepers have to watch all night in the vicinity to take the cubs out as they are caught.

Trapping is a common method of destroying foxes in mountainous districts. The usual way is to utilise a pool of water, and, making a road into the centre of it, place a bait with the trap skilfully covered on the road. It is necessary that the pool of water be near a spring, 


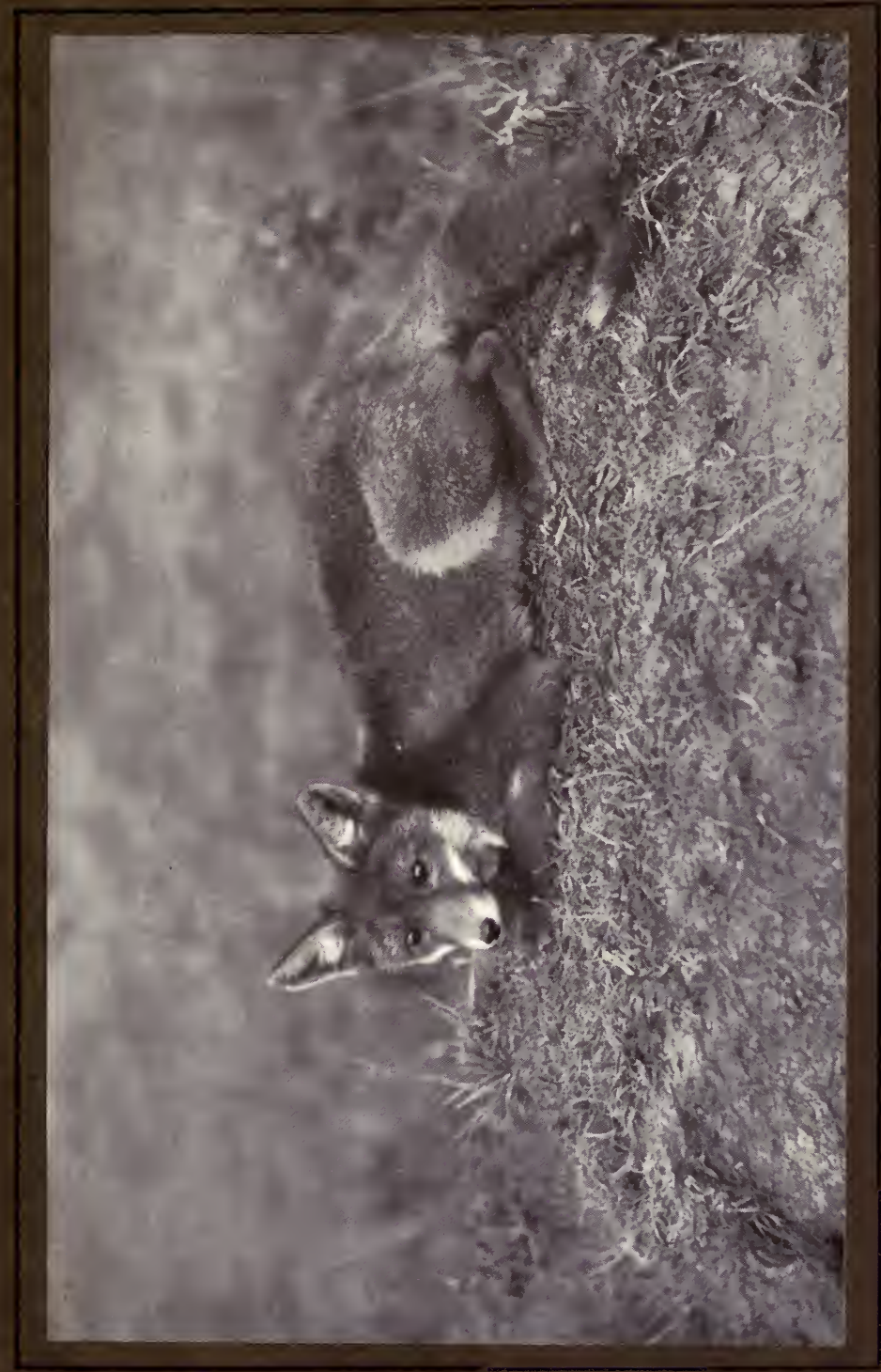

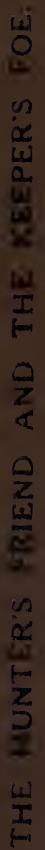



in order that a summer's drought may not interfere with it. Any carrion will do for a bait, and, so far as my experience goes, nothing is better than the carcase of a fox or cat, as Reynard is almost certain to be attracted by the smell, and so venture on to the treacherous trap. It may be well to mention here that the traps should only be set for foxes in places where they can be seen by the telescope from a distance, so that the keeper need never go near them except when he sees the trap has been sprung. The cunning of the fox is proverbial, and he quickly associates the smell of the keeper with the trap, and thus suspects danger. When, however, the scent of man evaporates, he becomes bolder, and ventures to the bait which attracts him.

A successful way of trapping old foxes in early spring is, if one is caught, to take out the bladder, bury the carcase-if possible among peat hags, or in such places likely to be frequented by foxes, - make a mound like a large mole-heap for a grave, set a few traps round the base, and sprinkle the contents of the bladder on it. So soon as human scent has disappeared, foxes are certain to pay this mound a visit.

Sometimes a couple of foxhounds are got to scour the valleys in the early morning in order to take up the scent and follow Reynard to his mountain fastnesses. On such occasions the co-operation of a large number of keepers is secured, and all the principal passes in the mountains guarded by guns. Many foxes are killed in this way. 
Another animal most destructive to game is the cat. The wild cat is now so rare that it is almost superfluous to refer to it as an enemy of game. Still, on one estate a few years ago about a dozen wild cats were trapped. As they were sent on to me, I had them stuffed and exhibited at a meeting of the Field Naturalists' Society in Edinburgh, when I read a paper on Wild Cats to the members. This paper found its way into the newspapers, and endless discussion ensued, when it was asserted by no mean authority that the genuine wild cat was long since extinct, having crossed with the domestic cat, and was not now the original Felis catus of Scotland. Sir Herbert Maxwell, in his Memories of the Months, states, however, that hehad some specimens sent from Argyllshire to Dr. Oldfield Thomas, of the British Museum, who pronounced them indistinguishable from the pure Felis catus. As cats have not the sagacity and cunning of foxes, they are easily trapped, and quickly fall a victim to the gamekeeper. The same remark applies to the domestic cat : having no suspicion, it is easily trapped. The destruction of cats by gamekeepers is a continual source of discord between him and his neighbours. Once they begin to hunt for game, their presence cannot be tolerated, and it is desirable that they be kept down. Great judiciousness, however, should be exercised by the gamekeeper, and when a domestic cat is trapped it ought quickly to be put out of sight and its fate kept secret.

The stoat or ermine weasel is a species of vermin 
that the gamekeeper has good reason to be afraid of. $\mathrm{He}$ is a merciless tyrant, a meaningless murderer, shedding blood from mere wantonness. Both ground and winged game fall victims to his bloodthirstiness. Even wood-pigeons are not exempt from his rapacity, as I have seen one in a pigeon's nest $10 \mathrm{ft}$. from the ground, and watched him throw the young birds over the nest and carry them off. The climbing capacity of the stoat can scarcely be credited : in a pole-trap 7 or $8 \mathrm{ft}$. from the ground, on the moor at Castle Menzies, in Perthshire, I witnesseda number of stoats captured. Whether they had scented the blood of birds that had been caught, or by what motive they were impelled to climb the pole, I cannot say, but the fact remains that the stoats climbed that pole and were secured in the trap at the top of it.

It is no use a keeper thinking that he has vermin trapped down on his estate, as the stoat is ubiquitous. Some years ago I collected five hundred stoats and weasels to transport to New Zealand, in order to cope with the rabbit plague. There were no rabbits and no stoats there till man introduced some rabbits, and with the most ruinous results. It was therefore found necessary to introduce the natural enemy of the rabbit, hence the transportation of stoats and weasels. Before they had been long in the colony, it was discovered that stoats had travelled a distance of ninety miles. Their scenting power enables them to track their prey like a beagle, and I have seen both rabbits and young hares 
lie down and squeal through sheer terror before a stoat was within many yards of them, when in an instant the stoat would spring on to the back of its victim, and, with that unerring instinct peculiar to the weasel tribe, seize it behind the ear, when, I am disposed to think, in many cases it sinks its tusks into the spinal cord. Fortunately the stoat is easily trapped, and nothing makes a better bait than one of their own species, their cannibalistic tendencies being a gruesome trait in their character. In the rabbit warren, in the covers, on the grouse moor, or by the hedgerows, the stoat demands the vigilance of the keeper. Some years ago a brood of magpies made their appearance in a strip of plantation, where a couple of broods of young pheasants had been frequently seen. Drilling holes in the side of three eggs and inserting a small quantity of strychnine, I had them placed in the strip late at night, in the hope that they would be seen by the magpies in the early morning. On going round, however, the eggs were gone, but there was no trace of the magpies. After a diligent search, I saw something white under some spruce branches, and on lifting them, found the eggs, two of them intact and one broken, while a large stoat, stiff dead, lay beside them. How it had removed the three eggs a distance of 62 yards, I cannot explain.

The weasel, though smaller in size, very much resembles the stoat. It is also very destructive among young game, and, like the stoat, bloodthirsty in its habits. Recently, while travelling over the moor of Tullymet, 
in Perthshire, in company with the keeper, we had our attention attracted by the peculiar action of a hen grouse jumping in the air. Approaching the place, we observed a weasel looking out of a hole among the heather. With the aid of our sticks we dug out the hole, and discovered five young grouse, about a week old, which had been killed and dragged in.

Another illustration in point. A neighbour's boy had a pair of rabbits confined in a house, with a brood of eight young ones nearly half-grown; and a second litter, seven in number, about ten days old. Hearing a noise about seven o'clock one evening in the rabbithouse, the boy went to ascertain the cause. On opening the door, a weasel made its exit by a small hole, and effected its escape. It was soon found that the entire fifteen young rabbits had been cruelly slaughtered, the speck of blood behind the ear revealing the spot where the weasel tribe, with unerring accuracy, seize their prey and quickly extinguish the lives of their victims. The noise which attracted attention was caused by the old pair of rabbits defending themselves as they best could; but there can be no doubt that had attention not been attracted, they would have shared the same fate as their progeny.

Another illustration in point. While collecting the stoats and weasels already referred to, I experimented with them for the purpose of acquiring knowledge at first-hand as to their bloodthirsty habits. It has been argued that wild predatory birds and beasts kill only to 8 
satisfy the cravings of hunger. Experience and observation, however, have taught me otherwise, as I have seen both ground and winged vermin kill for seeming amusement, or perhaps from innate cruelty. Should a weasel happen to come across a brood of young game before they are able to fly, every chick is certain to be ruthlessly destroyed. While experimenting with the weasels referred to, I procured a small mesh net-wire cage, $6 \mathrm{ft}$. long, $2 \frac{1}{2} \mathrm{ft}$. broad, and $2 \frac{1}{2} \mathrm{ft}$. high. Into a corner of this I introduced a box large enough to contain a weasel,-said box having a sliding door over a small hole. A dozen sparrows were also introduced, and these kept fluttering about the cage in wild excitement. Looking through a window and at the same time pulling a string, the sliding door was drawn open. Immediately the weasel put out his head, while his eyes kept changing to all the colours of the rainbow. His course of action was quickly decided on, and out he bounded among his prey. The dexterity displayed by the little wretch was amazing, as in a few seconds the twelve sparrows lay dead in the bottom of the cage. The way in which he jumped up and caught them in the air proved to my mind the dangerous nature of this class of vermin in a game-preserve. I afterwards regretted that I had not timed the slaughter of the sparrows by my watch, but I saw enough to convince me that the gamekeeper who neglects the trapping of weasels is "not worth his salt."

Recently I observed a weasel with something in 
his mouth, the brilliant yellow hues of which excited mycuriosity. Giving chase, he soon dropped theobject, and on picking it up, it turned out to be a frog which he had killed. This is the only occasion I have known a weasel to kill a frog.

Most keepers who have had experience in rearing pheasants are aware of the bloodthirsty habits of the weasel should it find itsway into the rearing-field. As an invariable rule, however, precautionary measures should be adopted by having traps set in every likely spot around the rearing-field. Care must be taken when the pheasantchicks extend their rambles that small conduits are made with stones, in which the trapsshould beplaced, in order to secure immunity from the danger of the birds getting into them. Weasels are easily trapped, and nothing keeps them down better than rabbittrapping, they being frequently caught in running in and out of rabbit-holes. Where stoats and weasels abound, it is most desirable to have a few flat stones or flags in suitable places, propped up by pieces of stick set with the old figure-of-four trap. The slightest disturbance fetches the flag down, and the victim is at once crushed to death.

The hedgehog is another species of vermin destructive to game. Its depredations are chiefly confined to nest-harrying. The amount of mischief done in a gamepreserve by hedgehogs is great. Again and again I have trapped them, using eggs as a bait, and have seen one in a pheasant's nest devouring the eggs. This was 
on the Ladykirk estate, in Berwickshire. The hen was sitting by the roadside, where she was seen daily by passers-by "in the know." On nearing the spot one evening, my attention was attracted by seeing the pheasant flying, or rather jumping up, flapping her wings, and making a chirring noise. On going forward, I found the eggs scattered in all directions, and some of them smashed in the scuffle, while a hedgehog was regaling himself in the nest. Discovering my presence, he gradually curled himself into a bristly ball; but, needless to say, he got short shrift.

The hedgehog has been known to kill very young hares and rabbits, and even half-grown pheasants. Not only so, but it has frequently been found entering coops and killing barn-door hens while acting as foster-mothers to young pheasants. The hedgehog's staple foods are snails, slugs, and beetles, but, as already mentioned, it is fond of flesh and eggs. Many people assert that it devours fruit, but, so far as my experience goes, - and I have dissected the stomachs of a large number,-it does not eat anything of a vegetable nature except small quantities of grass, which, I presume, are swallowed when it is grubbing for beetles among the roots.

Another enemy to game is the rat. After the rat is full-grown it acquires an appetite for flesh, and kills any young game it may come across, whether it be winged or four-footed. Rats are becoming a much more formidable enemy of the game-preserver than they used to be, as now they are burrowing more in hedgerows, so that 
it is difficult for partridges to nest and successfully hatch their young. The reason for this is obvious: the modern use of cement has quite baffled them in trying to undermine granary and stable floors; while sewer-pipes have displaced old-fashioned conduits, so that they no longer find farm-steadings a congenial home. They therefore take possession of rabbit-holes, where, in many cases, they are allowed to harbour and breed without restraint. Prior to the passing of the Ground Game Act, rabbits were in most cases killed by the use of traps, with the result that many rats were secured. Nowadays, rabbits on a farm are generally let to professional rabbitcatchers, who kill them in a simpler way, namely, by snares, with the result that rats get off scot-free. A large East Lothian farmer who had the shooting on his farm informed me that he would not allow a snare to be set. In trapping the rabbits the previous year, the man he employed caught i i 4 large rats. What the result would have been had these rats been allowed to remain and breed, it is not difficult to imagine. No effort should therefore be spared in order to kill down this species of vermin.

Game also suffers, though not to a large extent, from adders. I have seen one kill very young grouse and black game, and on dissection found that another had swallowed three nearly fledged larks. As the hand of every one is against adders, nobody misses a chance of killing them whenever an opportunity presents itself. 
At the head of the list of birds of prey stands the golden eagle. As already said, this bird has suffered much persecution on account of its depredations among lambs, and is now so scarce that many of our largest proprietors are preserving it. It is gratifying to all lovers of natural history that this should be so. At the same time, a pair of eagles do incalculable damage to a grouse moor, and more especially a driving moor. I have frequently seen drives destroyed by an eagle crossing the moor in aërial circles in the distance. The circumstance of their flying about drives the grouse from that locality, as they shrewdly regard the presence of the eagle to be incompatible with their security.

Some years ago I introduced seventeen mountain hares, from Dalnaspidal and Castle Menzies moors, in Perthshire, to Hoy, the most southerly isle of the Orcadian archipelago. Being very prolific, the hares soon increased to considerable numbers, when a pair of eagles made their appearance and nested in the Kame rock, on the north end of the island. They had long since deserted Hoy as a nesting-place, but the introduction and increase of hares again attracted them to this rock-bound island. The hares were quickly decimated, yet the proprietor is most anxious that the eagles should there find a congenial home.

Whether by unscrupulous egg-collectors who regularly visit Orkney, or by farmers enraged at the loss of their lambs, it is difficult to say, but the fact remains that eagles' nests are systematically robbed in 
Hoy. Recently, however, a pair nested in the perpendicular precipice near the crofter township of Rackwick, where they hatched their eggs and reared their young in safety. But it is difficult to preserve eagles where farmers, shepherds, and egg-collectors have access to the eyrie. It is therefore only in those wildernesses which are afforested that the species can be preserved in this country, as there they are allowed to harbour and breed without restraint.

It is now some years since a pair of eagles nested on sheep ground outside the deer forest of Strathconan, at that time the property of Mr. A. J. Balfour. As a number of lambs had disappeared during the previous year, and an eagle had even been seen in the act of carrying one off, the farmer vowed vengeance upon these robbers of his flock. After a number of such depredations, it was at last reluctantly agreed to destroy the eagles. Being consulted in the matter, I suggested that if we could manage to rob the nest, the parents could be spared, seeing it is only when they have to provide for their progeny that they carry off lambs. The keepers feared that to rob the nest was impossible, as the eyrie was in an inaccessible rock. However, taking with us a cart-rope, we wended our way towards the place. Getting above the eyrie, I tied one end of the rope round my waist and prepared to descend. Though very steep, we all managed to get down to a birch tree, to which my companions fastened the other end of the rope, in order partly to relieve them of the strain of my weight. 
I then managed to crawl feet foremost to the edge of the precipice, where I could see the sticks on the outer edge of the nest, though to reach it some io $\mathrm{ft}$. of sheer descent intervened. On being let over, I looked like Mohammed's coffin, suspended between heaven and earth. The rope now assumed a rotary motion which for me was anything but pleasant. Reaching the ledge, I called up to slacken the rope, and proceeded to examine the place which went some distance backwards, forming a sort of cavern. Closely cuddled together were two little downy eaglets, evidently only a day or two hatched. Exploring the cavern, I saw what was evidently the larder of previous years, as the bleached remains of lambs, red-deer calves, hares, rabbits, grouse, black game, ducks, etc., lay all around in profusion; while a newly killed grouse, neatly plucked and partly devoured, lay near the nest, doubtless supplying the rusks of eagle babyhood.

Putting an eaglet in each coat-pocket, I hallooed to be hauled up. This was by no means a pleasant process, as I was several times roughly jolted against the rock, with the result that the little eaglets were both crushed to death. They may, however, still be seen as stuffed specimens in the Royal Scottish Museum. I am no advocate for the destruction of the eagle, but, being gluttonous birds, they are frequently captured in traps set for foxes.

Next to the eagle, the buzzard is the largest bird of prey in this country. It lives a good deal on carrion, 
and as a consequence is easily trapped. It, however, takes grouse, as I have found their legs and feet at the nest. How it seizes them I have never been able to understand, but imagine it must snatch them off the nest, as never to my knowledge has a buzzard been seen in pursuit of grouse on the wing. Judging from the castings of the young birds at the nest, the buzzard preys largely upon rabbits, leverets, mice, moles, beetles, and caterpillars. As mentioned, however, I have seen the remains of grouse at their eyries. At the same time, the buzzard is not very destructive to winged game, so that, with the kite and hen-harrier, which are both now rare, I do not urge their extermination.

The peregrine falcon is a very difficult bird to deal with, nesting generally in inaccessible precipices out of reach of the keeper. As he scorns to be attracted by any bait unless killed by himself, it is exceedingly difficult to get rid of this most dreaded enemy of grouse. I know of places where peregrines breed, and even if one is shot off her eggs, the male immediately starts in search of another mate. I have known five hen birds killed out of the same nest in succession, so mates must be plentiful somewhere. When they are allowed to rear their young, a heavy toll is taken from the number of grouse on the surrounding moor. The fastest cock grouse that ever flew has no more chance before the peregrine than a rat has before a terrier in an open field. Only those who have concealed themselves near the eyrie of this bird, and with a telescope watched the number 
of victims brought to the nestlings, have any conception of the havoc they commit among winged game. I once sat for hours with a glass and watched what was carried to the eyrie by the peregrine. In five hours I saw five grouse brought, and it was interesting to note how dexterously he transferred them to his mate, which flew out of the eyrie and met him in mid-air. When the young are able to use their wings, they fly out and snatch the prey from their parents in the same manner. Notwithstanding the depredations among grouse, when in coveys, by the peregrine when providing for its nestlings, it is in the spring months that most damage is done, as he then breaks up the pairs, it being almost certain that either the cock or the hen will fall a victim.

The peregrine falcon is by far the noblest and most dashing of our British birds of prey. He is a bold and pitiless marauder, and Highland lairds will never know what rentals their estates can realise so long as this merciless tyrant among grouse life is allowed to harbour. Endless discussion has from time to time taken place in the columns of sporting and other papers between falconers, naturalists, sportsmen, and keepers, as to how a falconstrikes hisprey. Falconers determinedly adhere to the theory that it is done by means of the talons. It is difficult to reconcile this with the fact that some of the victims have not even a scratch on them,- - only a blue mark on the spine, the result of a severe blow. One can hardly understand how this blow could be struck by those terrible talons at the terrific pace of a falcon 


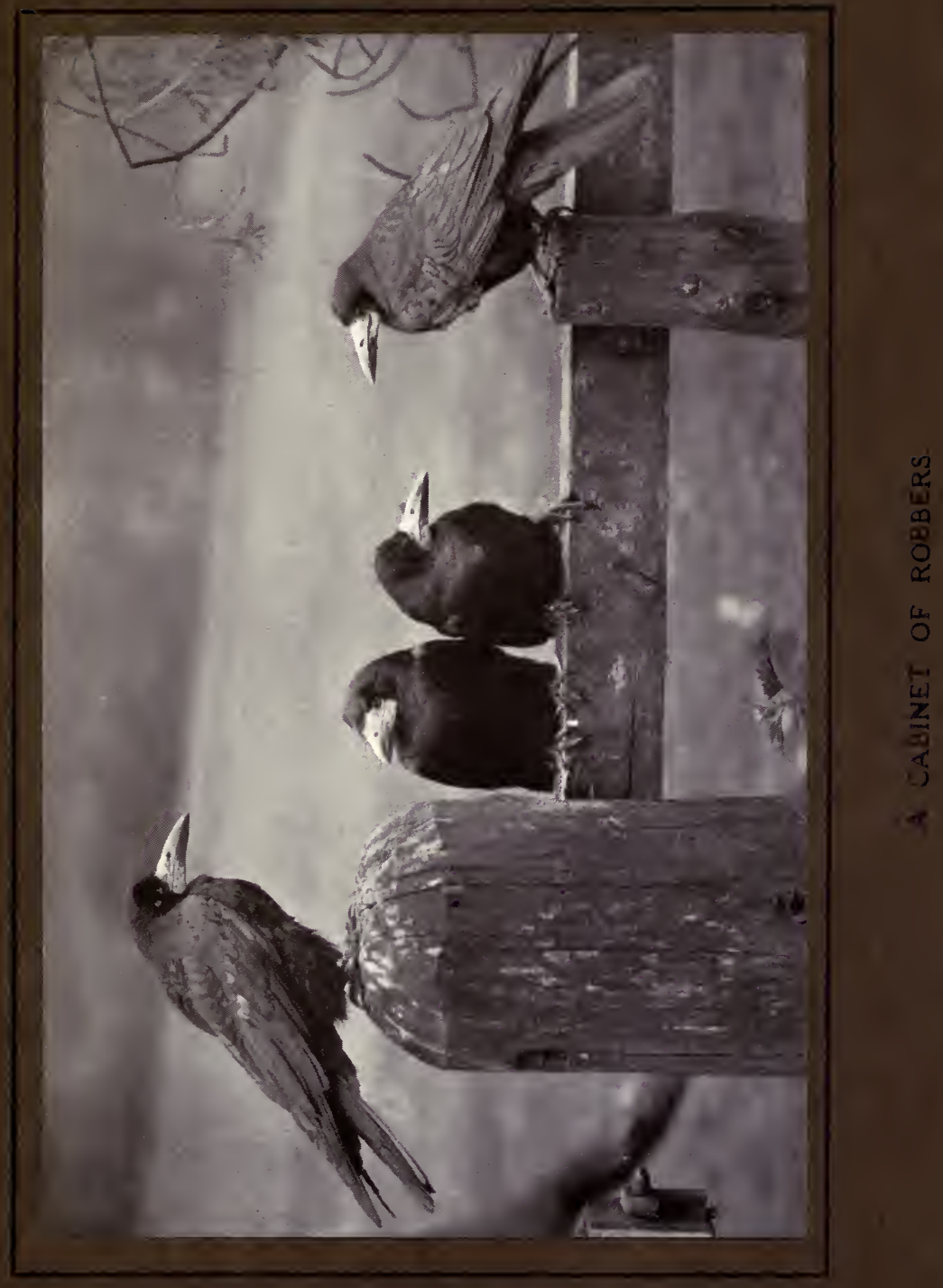



swoop without the skin being broken. At other times, when making a quarry, the peregrine cuts the head clean off his victim, the head and body being sometimes found yards apart. At other times the head is found hanging to the body by a bitofskin. Most keepers of myacquaintance who have spent their lives among the mountains are agreed that the peregrine strikes with his wing. Falconers, on the other hand, deny this, and assert the blow is struck with his talons. Their experience, however, is unfortunately only derived from birds kept in confinement. It has been noted by careful observers that when young peregrines commence to hunt for themselves, they clutch their prey; but, as can easily be understood, it would be dangerous to clutch and bind to a heavy bird such as a blackcock or a duck flying at its utmost speed, and they soon give up clutching. Personally, I have seen a blackcock, several grouse, a golden-eye drake, and a mallard struck down by the peregrine, the victims in every case being dead except the last mentioned, which was only stunned, and flew off when approached. Major Morant, who spent ten years of his life in the wilds of Ardnamurchan, after describing birds killed in the air by wild hawks, says : "The grand sudden death of these birds is certainly very different to the descriptions one reads of the way tame hawks take herons. After getting above them, they seem to settle on their backs (binding is, I believe, the correct term), and they descend to the earth together, scratching and fighting like a bagful of cats." 
Mr. Knox, in his charming book, Game Birds and Wild-Fowl, says : "It is because the breast-bone of the hawk isprotected with such strong pectoral muscles that the concussion which deprives its victim of life can have no injurious effect upon the author of the momentum which causes the injury."

How, then, are peregrines to be got rid of? This is the question pressing for solution, on a moor where they take up their abode. Preparatory to nesting, these birds are sometimes seen flying about the top of a cliff. I previously recommended a number of cairns to be built with stones to a height of from 4 to $5 \mathrm{ft}$., so as to be out of the way of sheep-these cairns to taper to the top, and be capped with a turf or divot, in which a hole could be cut out. When a trap was placed in this hole and covered as carefully as possible, it was found that the peregrine was frequently caught. I have known many peregrines killed in this manner. As these traps were generally set in high altitudes, exposed to the sweeping blasts, there was difficulty in keeping them covered with earth or other suitable material. The peregrine is a 'cute bird, hence the necessity for careful covering.

The falcon, as already observed, is the most dashing of our birds of prey, and to see him making a quarry is something to be remembered. $\mathrm{He}$ is, however, a merciless tyrant, a meaningless murderer, shedding blood from mere wantonness. I have seen him strike down a blackcock and continue his flight without taking 
the trouble to look after his fallen victim. Few have the slightest idea how destructive he is. As is well known, grouse indigenous to Britain realise a pound per brace, and shooting rents pay a large percentage of local taxes. The peregrine pays neither rent nor taxes, but it would be interesting to ascertain how many grouse at a pound per brace one pair annually destroy. This will never be ascertained, as every grouse killed between February and June means the destruction of a covey ; and, as already mentioned, I have seen them, when catering for their young, bring five grouse to the eyrie in five hours. In the crofter township of Rackwick, in the island of Hoy, the peregrine frequently swoops down and carries off domestic chicks close to the cottages. Would any lover of birds tolerate this? Much as this dashing bird of prey may be admired, his presence must be regretted, though with such spots as the stupendous cliffs of Hoy to breed in it will probably baffle human ingenuity to get rid of them.

The sparrow-hawk, the merlin, and the kestrel are the only other birds of prey which it is necessary to refer to here, other species being now regarded as rarce aves. The two first mentioned are both very destructive among young game, and it is most essential that they should be kept down. Sparrow-hawks are exceptionally destructive, and whenever they make their appearance in the "warbling grove it is only for the purpose of depredation, and they are gloomy in- 
truders on the general joy of the landscape." I have found the remains of over twenty young pheasants at the nest of a sparrow-hawk, and have frequently seen him carrying off blackbirds and thrushes, it being painful to hear the piteous screams of the victims as they were borne off in the cruel talons of the hawk. It will thus be seen that the successful rearing of game is impossible when this bird is allowed to exist. The vigilance of the keeper is therefore necessary to find out the nesting-place, and when this is accomplished the destruction of the pair of birds is a simple matter. To put the hen bird off the nest, then conceal oneself within range and shoot her as she returns, is the general mode of procedure. If this can be done at night, so much the better, as by being in concealment before daylight the following morning the cock bird will make his appearance, generally affording an easy shot. Many prefer to trap the cock bird on the nest, which is easily done. On dissecting the last sparrowhawk I shot, the crop was found to contain the entire wing and other parts of a young grouse, while in the gizzard were the remains of small birds and other matter partly assimilated.

Though this hawk skims along and seizes birds as above described, it also lifts its quarry from the ground, but, with the exception of carrying off young pheasants in the rearing-field, it is seldom seen in the act. I have, however, witnessed it strike down a wood-pigeon after the manner of a falcon. In this instance the 
pigeon was flying across a field, when the hawk dashed down with lightning speed on its victim. I saw the hawk distinctly for a hundred yards before it struck. It is difficult adequately to describe the mode of attack, further than to say that the hawk assumed the shape of a wedge, the wings being taut "as sails filled with a stiff breeze." In an instant the blow was given, a cloud of feathers flew from the pigeon, and it fell lifeless to the ground. Running up and hallooing, the hawk flew off. Picking up the pigeon and plucking it, not a scratch was visible; but death was evidently due to what appeared to be a severe bruise along the backbone. Those who have noted the sharp claws of the sparrow-hawk will have difficulty in believing that the blow is struck with them, otherwise some part of the skin must necessarily be torn.

The merlin-the smallest British bird of prey-is a handsome bird. $\mathrm{He}$ is, however, a merciless tyrant among small birds and young game, and his presence cannot be permitted by the game-preserver. Though destructive to game, he is more of a small-bird destroyer, and a pair of them are computed to kill a thousand birds in a year, including, of course, those carried to their young. I have never seen a merlin kill a bird larger than a thrush, but Major Morant says: "We once put up a hen grouse in the month of February, which was immediately pursued by a merlin. On coming over a ridge which had concealed the birds from our view, the merlin rose from the heather; and 
on going to the spot we picked up the grouse, which died in our hands. The grouse weighed twenty-four ounces. The skin was not broken, but she had a tremendous bruise over the spine." The merlin, as far as my experience goes, breeds on the ground, generally in the bank of a gully in the open. It is asserted that it occasionally breeds in rocks and trees, but this has never come under my observation.

The kestrel is the most common of our British hawks. He is a pretty object, for who does not love to see him hover? I am unwilling to shoot kestrels, as in the crop and gizzard of those I have killed I have found that mice, beetles, and caterpillars were usually present. It cannot be denied, however, that when catering for their hungry nestlings, young game are carried off in large numbers. That distinguished naturalist, the late Duke of Argyll, instructed his keepers not to kill kestrels, as they were harmless to game. His Grace, however, changed his mind on the head-keeper showing him the remains of many grouse at a kestrel's nest. When the kestrel makes a practice of visiting a field where pheasants are being reared, he is even worse than the sparrow-hawk. The latter comes at pretty regular intervals, and the keeper can depend upon him coming. Unless he be fired at, he will return to the same part of the field, frequently to the same coop, so that, as a rule, he is easily shot. The kestrel, however, is quite different in his habits. $\mathrm{He}$ may come twice within an hour, and perhaps not for 
a day or two. He is much more wary, perches on a tree and surveys the scene, or hovers to mark his prey, darts upon it with unerring aim, and is then off like an arrow. The least movement alarms him, and he suspects any unusual object. If fired at and missed, it takes some ingenuity to get him. Fortunately, he does not take young pheasants after they are about a fortnight old, in this being unlike the sparrow-hawk, which takes them till they are as large as he is fit to carry. Still, I do not advocate the destruction of this beautiful bird. Let the keeper find the nest, watch what is brought to it, and use his judgment as to whether or not the death warrant should be pronounced.

It is because some naturalists attempt too much that they are not listened to. What is the good of talking of ignorant keepers, and of saying that kestrels do no harm to game, when most of these men have shot them in the act?

The raven is the largest of the corvidæ, and well known for its cruel rapacity on sheep-farms. It is not uncommon to find the eyes of sheep and lambs pecked out on the hills where these birds are allowed to exist. They are by no means so scarce as people believe, being still found in large numbers in the mountainous districts of Scotland. I have a couple of them as pets, and dirtier or more cruel ones I never possessed. Strange to say, some of our County Councils are protecting ravens, which act savours of ignorance on their part as to the habits of these birds. The raven nests 
very early, and with their young broods may be seen flying about from daylight till dark. Indeed, it is surprising how anything escapes them. I have seen a brood of ptarmigan, while enjoying themselves on the mountain tops, suddenly attacked by these sable butchers. The peculiar cry of the old birds, as they tried to lure the ravens away, was of no effect. The young brood squatted out of sight as they best could, but the keen eyes of the ravens soon discovered them, and the helpless ptarmigan were duly gobbled up. I managed to shoot one as they circled near my place of concealment, and in the gizzard I found a brace of young ptarmigan which had been swallowed whole. The same tactics are followed with a covey of grouse, and it is easy to see that a heavy toll must be taken off by ravens in those districts where they abound.

The hoodie-crow and the carrion-crow may be bracketed with the raven as enemies of game. The destruction to grouse eggs by these birds is incalculable. Sometimes a hoodie's nest will escape the vigilance of the keeper. In such a case I have seen the shells of hundreds of grouse eggs at a spring a short distance from the nest. It will thus be evident how impossible it is for game to be reared with carrion-crows in the district. Young grouse are picked up by these birds, even after they are half-grown. I have seen a pair of hoodies endeavouring to get at young grouse which were pretty well grown, and had got their tail feathers. So resolute were the savage birds in their purpose, that 
they never observed me, though I was concealed within forty yards. The old grouse succeeded in driving the crows off before they got a young one. The siege continued for fully twenty minutes, when one of the crows, in circling round, at last got his eye on me, and uttered that peculiar call to his mate, when they both quickly winged their way up the glen. On going to the spot, I found a lot of feathers lying about, and certainly but for my presence they would have succeeded in their merciless work.

Setting the game-preserver aside, the destruction of these birds is necessary in the interest of the stockfarmer. Recently, on the farm of Cardon, in Peeblesshire, shortly before lambing, a blackfaced ewe had both her eyes pecked out by a hoodie-crow. Fortunately she was discovered alive, and with careful nursing the animal recovered and gave birth to a lamb, which she successfully reared. When the shepherd called for her, it was interesting to see her run and eat porridge out of a basin. Writing on a subsequent occasion, the owner of the ewe said: "This spring a blackfaced ewe hogg had been treated in the same barbarous way, and had to be destroyed."

The magpie feeds much in the same manner as the hoodie, though it searches amongst underwood more, in order to get at the nests of small birds. The nests of the pheasant and partridge are very frequently discovered by the magpie's sharp, piercing eyes, after which shells will be found minus the contents. The 
vigilance of the keeper should never relax so long as his ground is infested by any of the corvidæ species. Though he should manage to shoot the hen bird off her nest, he must not imagine that he has destroyed the brood for that year. Another mate will soon be found, and hatching will go on. I have repeatedly shot a magpie off her eggs, and in a few days a second one shared the same fate. There appears to be a registry for unmarried magpies somewhere, as no sooner is one shot than another one is secured, and domestic arrangements go on as before. A pair of magpies recently nested in a tree close to my home. When the process of hatching was commenced, I had the bird disturbed and shot as she flew from the nest. Early the following morning a number of magpies appeared, and a great deal of hilarious chattering around the nest indicated to my mind that, in " pyet " language, a wedding was going on. The hilarity was brought to a sudden termination by a shot from the centre of a holly bush, when they quickly dispersed, minus one, which fell to the ground. This continued in the early morning for a week, during which no fewer than six magpies were secured. Though I have all my life trapped crows and magpies with bits of rabbit and other flesh, eggs have an irresistible attraction for these birds.

With regard to owls, much diversity of opinion exists as to the damage they do to game. Many naturalists assert that they are perfectly harmless, but, 
as the result of practical observation, I fearlessly assert that they are wrong. I would not shoot an owl on any consideration, and they are in great numbers at my home, where they breed in holes in the old trees. (The tawny species is here referred to.) At the same time, were pheasants or partridges being reared, or a large head of game expected, owls would not receive the same generous treatment. In Sir Herbert Maxwell's book already alluded to, the Memories of the Months, when writing on owls the author dwells at considerable length on the habits of these birds. Much as I respect this distinguished writer, I regret that, as a Scotsman, he does not give us the result of practical observation in his native country. Instead of this, he prefers to quote from a German author, Dr. Altum. He states that this German doctor examined 2 Io pellets of the tawny owl and 706 pellets of the barn-owl, and goes on to enumerate the number of mice, amounting to thousands, found in these pellets. Why such a recognised authority should go to the Continent, where birds of the singing class are conspicuous by their absence, in order to find the pellets of owls, requires some explanation. Surely this Scottish naturalist could have found owls and made his observations on his own extensive estates, instead of having them " made in Germany." I have all my life picked up the pellets of owls to examine them, and have found the remains of all song-birds. One picked up the other day contained the feet and feathers of a thrush. A 
sentence in the book above quoted would seem to indicate that the author had been nodding. He says he does not doubt that if any young chick or pheasant " comes in the way, the owl will pounce on it and enjoy it mightily. But," adds Sir Herbert, "young chicks are not, or ought not to be, abroad in the night, which is the only time that most kinds of owls can hunt." It is exceedingly unfortunate that distinguished authors should record their opinions instead of their observations. I have no desire to dogmatise on this subject, but have again and again watched tawny owls at the nest, as well as taken them from the nest and placed them in a box, when from a window I could observe what the parent birds brought to them for food. They usually commenced to carry food to the young between three and four in the afternoon. I therefore exhort all young keepers to do the sameto watch and carefully note the victims of the owl, and so explode the theories of mere litterateurs. It will be no use the young keeper doing this for one season only, as the abundance or scarcity of mice depends largely on climatic influences, and when mice are plentiful there is no doubt that large numbers are devoured by owls. The results of my observations as to the food of owls compel me to include the following: young hares, young rabbits, bats, young pigeons both wild and tame, ducklings, thrushes, blackbirds, sparrows, and all the smaller birds, moths and beetles. It is right also to mention that in some seasons a very large number of 
mice-both the vole and the long-tailed field-mouseare included in the owl's bill of fare.

The tawny owl has also been known to kill fullgrown pheasants. In a large open pheasantry at Inveraray, Mr. Cameron, the head-keeper to His Grace the Duke of Argyll, and an observant naturalist, discovered that hen pheasants were being killed and eaten by some animal, though he could not at first make out which. He suspected rats, and had traps set to try to secure the depredator, but without success. One morning, however, after a fall of snow, he found another dead pheasant, but the mark of the feathers revealed the fact that owls had been the murderers. He therefore baited a trap with the partly eaten pheasant, and erected a pole near by, on the top of which he placed a pole-trap. By seven o'clock that night a tawny owl was caught in the pole-trap, and in the morning another was in the baited trap. At the same place a number of ducks were being hand-reared and enclosed by wire-netting, to prevent them straying. The ducklings were fed at six o'clock in the morning, and between nine and ten in the forenoon ten of them were missing. Two keepers concealed themselves, and very shortly a hen gave the alarm which made them look out. So stealthily and noiselessly did an owl glide in, that he was not seen or heard till he was in the act of pouncing on a lot of ducklings which were clustered together, basking in the sun. He was so near his quarry that the keeper could not shoot without killing the ducks, but his sudden move- 
ment frightened the owl off, when he made straight for a tree near where the other keeper was concealed and perched above him. Needless to say, his ravages among ducklings were avenged. As I recorded in the Scotsman some time ago, a tawny owl picked up a squirrel on the public road at midday; and I have discovered, by placing weasels and short-eared owls together, that the weasels were killed and devoured by the owls.

The short-eared owl is a winter visitor, and as it is only on rare occasions that it breeds in this country and has a chance of seeing young game, I would plead for its protection. During the vole plague on the Border pasture-lands about a dozen years ago, scores were to be seen nesting in the heather like grouse, and laying as many as ten and twelve eggs. While studying these birds in Ettrick Forest, I took a couple of young ones home in my pocket for the purpose of finding out as much as possible about their habits. It has been demonstrated beyond all doubt that in whatever part of the world a plague of mice appears, short-eared owls, impelled by a powerful instinct, are sure to follow and devour them. How they make the discovery is one of those mysteries in nature upon which we can only speculate. Capital was made out of the mice plague by farmers, on the ground that the destruction of pasture by the mice was traceable to the destruction of hawks, owls, etc., by gamekeepers, in the interests of game-preservation. Unfortunately for the advocates of this theory, mice plagues had periodically appeared in different parts of 
the country centuries before game-preservation was ever thought of, and, strange to say, they were followed and devoured by short-eared owls. Perhaps the earliest record we have of mice plagues is found in I Samuel vi., where it is stated that the Philistines made golden images of "the mice that mar the land."

I would also spare the barn owl, for the following reasons : he is a splendid mouse-destroyer, is now rare, and is a beautiful object in nature. This bird is common in most parts of the south country, especially amongst spruce woods, where it sits screened from observation during the day. It is easily known by the "horns" or tufts of feathers on its head. Usually selecting the old nest of a pigeon or carrion-crow, it deposits its eggs, generally five in number, and few birds display more faithfulness and bravery in defence of their nest and young. After a heavy shower of snow and severe frost the following night, in the month of March, I have seen one frozen to the nest, though, lifelike, covering her eggs.

Long-eared owls are very destructive among pigeons, and occasionally among young game, but the sparing of them must be left to the good sense of the keeper, who should endeavour to satisfy himself as to how far their destruction would be justified. The same remark applies to the jay, the rook, and the jackdaw.

Legislation has recently been cutting very queer antics. A Bill has passed through Parliament, and been put upon the Statute Book, abolishing the pole-trap, or 
any trap put on a tree or in an elevated position. It now reads-

(I) From and after the passing of this Act, every person who on any pole, tree, or cairn of earth or stones, shall affix, place, or set, any spring trap, gin, or other similar instrument calculated to inflict bodily injury to any wild bird coming in contact therewith, and every person who shall knowingly permit or suffer, or cause any such trap to be so affixed, placed, or set, shall be guilty of an offence, and shall be liable on summary conviction to a penalty not exceeding 40s., and for a second or subsequent offence to a penalty not exceeding $£ 5$.

(2) Every offence under this Act may be prosecuted under the provisions of sect. 5 of the Wild Birds Protection Act, I880; and

(3) This Act may be cited as the Wild Birds Protection Act, I904, and shall be construed with the Wild Birds Protection Acts, I 880 to I902.

This pseudo-humanitarian sentiment has for its object the prevention of cruelty. No one will deny that trapping in any shape is cruel, but a modern pole-trap is more exempt from the charge of cruelty than any other form of gin or snare. Mr. C. M. Pelham Burn, the inventor of the humane pole-trap, used it with great success on his moors in Morayshire. It differs from the ordinary pole-trap in that the jaws strike high and catch the bird by the middle, so causing instant death. 'The Bill in question has, however, now become law, 
and the trapping of a sparrow-hawk on her nest, or of a peregrine on a cairn, is, of course, illegal, so that these tyrants among bird life, especially the latter, have practically free scope to butcher our beautiful grouse, which constitute one of the greatest attractions of our Scottish Highlands.

It was surprising how this Bill was supported in both Houses of Parliament by members who possess a large amount of territory in the Highlands of Scotland. The many hundreds of thousands of acres which constitute the rugged background of our Scottish scenery, and which are in many cases owned by members of our Legislature, might at all events have been regarded as a sufficient sanctuary for the protection of rare birds and beasts. Such, however, was not the case, and the poor lairds who own a few thousand acres of heather must submit to their grouse, which in many instances constitute their bread and butter, being torn to pieces by birds of prey. We have here an amount of selfishness on the part of several of our large Scottish proprietors for which I, for one, feel humbled and ashamed. Surely they might have protected birds of prey in their own forests, and left it to the discretion of their poorer neighbours to do as they pleased. Intoxicated with their own importance, however, a few pseudo-humanitarian M.P.'s brought in a Bill which has passed into law abolishing the pole-trap. Whether they will instruct their keepers to act in accordance with law, and refrain from setting traps in "an elevated position," had better 
be left unasked. In a recent conversation with a keeper to one of those who voted for the abolition of the poletrap, I remarked that he would have to set an example and refrain from trapping hawks. With a peculiar twinkle in his eye, he significantly replied, "Imphm."

After a fall of snow the young keeper should be out at daylight to note his observations of footprints. When the ground is covered as with a sheet of soft white paper, impressions of all birds and beasts are easily made upon its surface, and can then be read as in a book. A study of the tracks of the various kinds of vermin is most interesting, and every keeper should be able to discriminate at once what made the impression. Many traits in the habits of birds and animals, unobserved at other times, can then be accurately noted. A study should also be made of the disturbed cries of every denizen of the wood, as these constitute a valuable guide in detecting the enemies of game. The intelligent keeper knows at once if a stray cat, dog, or fox is in the wood. The warning cackle of a cock pheasant, the screeching of a jay, the excited piping of blackbirds and other birds, or the disturbed movements of any living thing, quickly notify to his practised ear that an enemy is abroad.

I am a game-preserver and a lover of birds. As man has dominion over the fowls of the air and beasts of the field, the destroyers of the birds we value most must be kept in check. As I have tried to show, a pair of peregrines, sparrow-hawks, or merlins must necessarily kill a thousand birds annually, and no one can affirm 
that bird-preservation and hawk-preservation are synonymous terms.

Properly understood and judiciously carried out, man's dominion over the beasts of the field and the fowls of the air is merciful as contrasted with that of the struggle for existence and the survival of the fittest. In the interests of the food-supplies of the nation, and having regard to the pleasure and profit of mankind, it is the duty of all to preserve birds and animals which are useful by destroying those that prey upon them. 


\section{NOTES}




\section{CHAPTER VIII}

\section{The Apprentice Keeper}

What we have already said will give the young man whoaspires to be a gamekeeper some idea of thequalities of character and temperament, and of the knowledge and skill, that go to make a successful servant. There are one or two other points we may indicate that may be of use to the uninitiated at the threshold of his career.

First, let it be stated that the sooner he starts his work the easier it will be for him to learn.

It goes without saying that no man deficient in power of observation or in ordinary intelligence should ever think of giving his life up to the care and the pursuit of game. The 'prentice hand must not only have a good ground work of the common rudiments of reading, writing, and arithmetic, but must be keenly interested in natural history ; for, unless he is careful in reading up and noting the haunts, habits, and peculiarities of the various beasts and birds which people his district, he will never be a success in the sphere he has selected for his life's work. And having noted such facts, he will never attain to any great height of trustworthiness and 
dependence unless he is able to put facts together in his mind and make the necessary deductions. How often do we find a keeper whose brain is well stored with facts and experiences, yet it is so stored that each item seems to be pigeon-holed in a separate department in his brain, and not on speaking terms with each other? Let, therefore, the wise apprentice start in life with the belief that everything is done for a purpose, and that there is some connecting link between cause and effect. Let him always be asking in his own mind the question -why? At first he may have great difficulty in finding an answer, and then the question must be repeated aloud to those who know, whose duty it will be to explain, and to direct the eyes and the brain of the prentice to observe facts and reasons which have eluded him. Let him remember this law - that everything is done either from reason or from experience, and that the rule-ofthumb gospel is only for the inefficient and incapable workman. There are very few things in this world that should be done merely from routine and habit. The 'prentice must therefore get into the practice of using his eyes, his memory, and his power of reasoning. In saying so much, let us recall what was expressed in the first chapter. On no account should he pretend to know when he is ignorant, or pretend to be ignorant when he knows. The man who is too conceited to admit his ignorance will never learn anything, and the man who is so goodnatured as to hide his knowledge for the sake of being 
pleasant, may be a good courtier, but he is a dishonest servant.

Generally speaking, the first duty of the apprentice gamekeeper is to be kennel boy. Simple as it may appear, the keeping of a kennel requires a good deal of attention and intelligence. It is sad to see how often a valuable kennel of dogs is subjected to neglect. Unless the head-keeper has a knowledge and a keen love of dogs, it is impossible that the kennel boy can be properly trained. It will add to his store of knowledge if he can borrow or acquire books written on the subject, provided he has sufficient intelligence to discriminate what is practical from what is not. There are two or three points which may be briefly noted(I) The kennels should be kept scrupulously clean, and periodically disinfected with weak carbolic and water ; $(2)$ the bed, which should consist of clean straw, should be shaken up every day and any dust swept out of the benches. Let the 'prentice keeper note the appearance of a dog that sleeps in a stable among clean straw, and he will at once understand the necessity for cleanliness in the bedding of dogs. There is nothing a dog seems to revel in more than a roll among clean straw when it is put into his bed. (3) After the kennel has been washed, or during very hot sunshine, dogs should not be allowed to lie upon the pavement, as their bodies are apt to draw damp from it and rheumatism results. Many dogs are rendered unfit for work by neglecting this important precaution. (4) The ro 
dogs should get plenty of fresh water, and be fed regularly.

The 'prentice keeper should always be out with the head-keeper when he is training his dogs. As to the management of dogs in the field, the experience must be gradually acquired, but the perusal of books on dogbreaking by such authorities as General Hutchison, Sir Henry Smith, and others, may be useful in giving him hints. But without observation, common sense, patience, and perseverance, he will never become a practical dog-breaker. However pure the breed and however satisfactory the condition in which dogs may be kept, perfection in breaking is neither to be secured nor expected except with very considerable experience amongst game.

The 'prentice keeper must also, as soon as possible, be put in contact with ferrets. He must be instructed as to the cleaning of their sleeping and feeding quarters, and learn in detail the whole question affecting their breeding, their feeding, and their working. Next to these, the management of hill ponies and other horses used in sport must come under his observation.

Of other matters for early observation mention must be made of the burning of heather, the improvement of soil, and questions of draining, fencing, planting. In all these matters the 'prentice keeper should be compelled to use his hands as well as his brains. His early days must be partly those of a labourer, a joiner, and a forester. He will find that having dealt with these 
matters in a practical way, he has laid a better foundation for his position as keeper than if his knowledgewere only based on observation and theory. Let him have an accurate knowledge of the use of the spade, the saw, the hammer, long before he knows the use of a gun.

The third part of his training should be concerned with the "engines" of sport, with the construction and use of snares, traps, and nets, and, finally, of guns. $\mathrm{He}$ must not only see the former set by others, but he must be allowed to set them himself; great care being taken that he understands the why and wherefore of his procedure, and to see that he proceeds, not from theory or imitation merely, but from his knowledge of the habits and habitats of game.

While he is learning these branches of his craft, he will, of course, be out with the guns, acting as beater, driver, stop, flank, or marker, and thus slowly accumulating valuable knowledge as to the questions of finding birds and bringing them to the guns.

At this stage the present book, it is hoped, will be intelligible to him, and he will be well on the road to become a qualified keeper. 
NOTES 


\section{CHAPTER IX}

THE MOOR

\section{Grouse-Black Game-Ptarmigan}

\section{By P. JEFFrey MACKIE}

IT is as well for the gamekeeper never to lose sight of the fact that upon his diligence and skill in attending to the moor depend to a large extent the success of the shooting season, in as far as it is affected by the amount and the condition of the stock of birds. So clearly is this recognised by all sportsmen, that a well-known authority ${ }^{1}$ has laid down the following dictum: "I have always observed that where there are really firstrate and honest keepers, there is always a pretty good stock of game. Of course seasons will vary, and any one used to the moors will know pretty well when to make the allowance for bad weather, etc., but it is astonishing how lightly moors will suffer from this cause or from disease when the keeper and his subordinates are thoroughly trustworthy. Of course you cannot grow figs on thistles; and when you have a bare, grassy, waterless, or rank heathery moor, it is useless to look for birds in anyamount, but in an average case, with average

$$
1 \text { Mr. A. Stuart Wortley. }
$$


conditions, the number and health of the birds will be affected by the conduct and care of the keeper in charge."

The main points to be attended to by the keeper in the management of a moor are-

I. The judicious burning of the heather.

2. The regulation of the water-supply.

3. The elimination of vermin.

4. The suppression of poachers.

5. The feeding of the birds in hard weather.

6. The introduction of new blood.

7. The destruction, in the autumn, of old cocks.

8. Judicious planting round and upon lower parts of the moor, useful for sheep and birds.

9. Careful and reasonable control of the number of sheep.

Io. The laying down of grit and lime.

II. The removal and burning of all dead matter, such as dead grouse, dead crows, dead vermin of all kinds, but particularly the carcases of sheep.

I2. The careful bushing of wire fences and the placing of discs of metal on any telegraph wires that may be near.

I3. The keeping down of bracken by cutting in June.

These points may be considered seriatim:-

I. Judicious Burning of the Heather.-Theburning of the heather depends, of course, upon the conditions of the weather in different parts of the country in different seasons, but it may be laid down as a general rule that 
the best time for burning is as soon after the legal day, Ist November, as possible. Although I know it is a disputed point, my experience has been that heather burns more thoroughly in the autumn than in the spring, if one can get a spell of dry weather. Though it may appear green, there seems to be an oil that keeps it alight, and one can burn against the wind, the flame eating up everything as it goes. On no account put off to the last few days, as many keepers do. During this period advantage should be taken of every dry day. Heather-burning is controlled in Scotland by an Act passed in 1773 , whereby any person setting fire to heath or moor between IIth April and ist November is, on conviction, liable to a penalty of $£^{2}$ for the first offence, $£ 5$ for the second. and $£$ io for the third and every subsequent offence, or, failing payment, imprisonment. The owner, tenant, or occupier of the said lands shall be found guilty unless he can prove that the fire originated on other lands, or was caused neither by his tenants nor members of his household. An extension of time until 2oth April may be obtained by proprietors of wet or high moorlands which are in their own occupation. As, however, this is about the date when birds generally start laying, great care should be exercised, and if there are any signs of eggs, no more burning should be done; if the lands are let, proprietors may authorise their tenants to burn under the terms of this extension. Notice must be sent before commencing operations to the sheriff-clerk of the county, along with a fee of is. 
Landlords should, in granting leases, stipulate that the tenant shall only burn the hill or moor jointly with the proprietor's keeper, both he and the tenant supplying an equal number of men. Keepers should never be off the moor in time of heather-burning.

When a moor has been badly neglected and is covered with acres of thick, old, and rank heather, burning should be carried out in a more radical fashion than is necessary on ground that has been carefully attended to in the past. In the former case, heather may be burned in long narrow strips of a width of some 25 to 30 yards. These strips should, if possible, be spread fairly equally over the moor. In exceptional and very bad cases it may be necessary to burn a very large tract of old rank heather. But, excluding these badly neglected cases, the best principle is to burn the heather in small patches, uniformly, all over the moor. The reason for this is fairly obvious. The necessary cover must never be at too great a distance from the feeding-ground of the young birds, which is generally young heather of some few years' growth. Justice is necessary for the younger birds, who are liable to be evicted from their feeding-ground amongst the young shoots by the older birds, when the heather has been burned in long strips. When small patches of heather are burnt, it is more difficult for the old birds to see their younger brethren, or cousins or nephews or nieces, as the case may be, when they are feeding and sunning themselves. In proceeding to burn the heather, the 


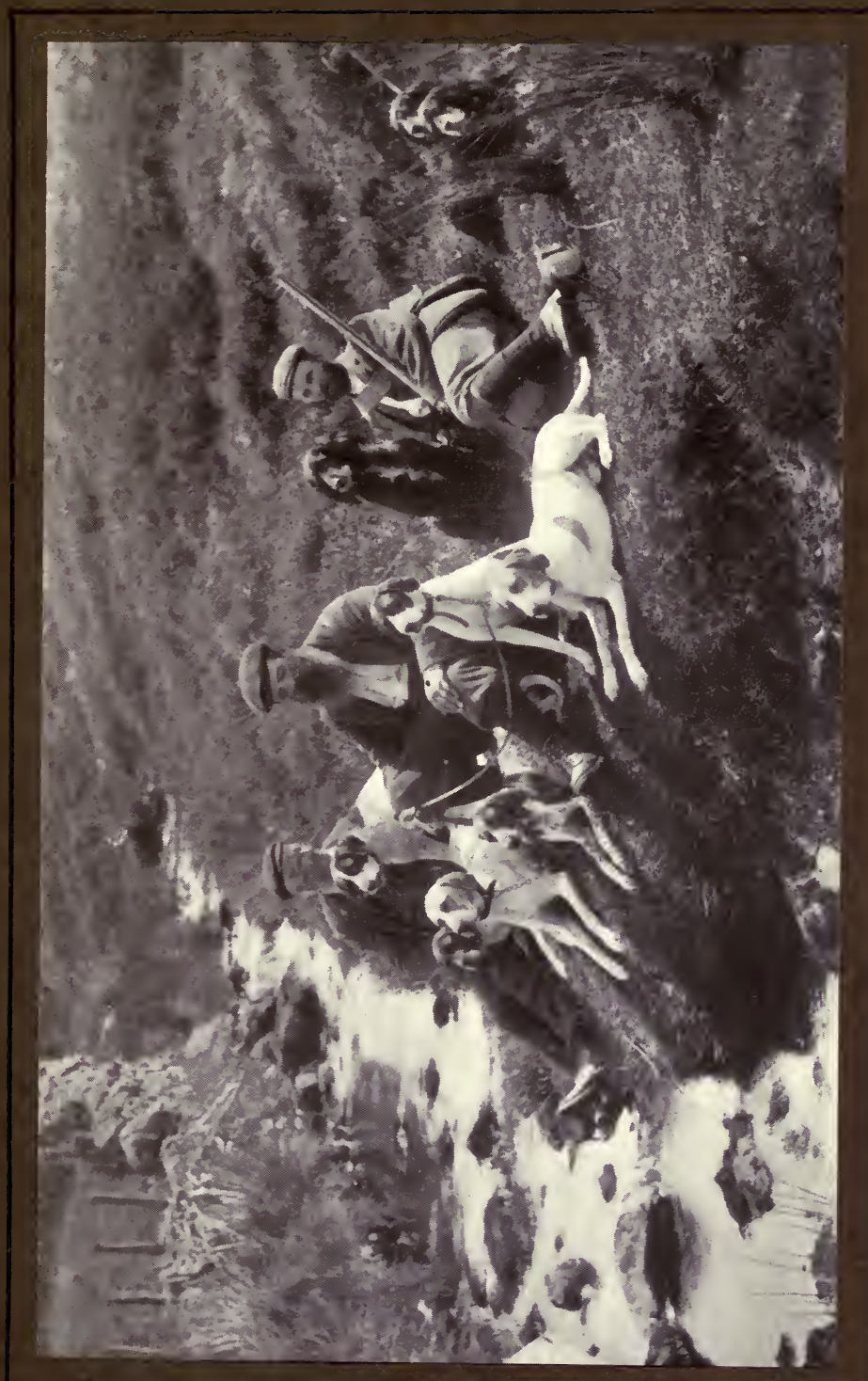

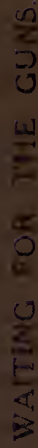


keeper must take into consideration the dryness of the moor and the direction of the wind. He should always be accompanied by at least two assistants to control the fire and to prevent it from extending too far.

The keeper must always remember that the danger lies not in over-burning but in under-burning. Old heather, whether dry and rank, or, as is usual, very damp underneath, is a plague to any moor, supplying healthy food neither for birds nor sheep. It hardly seems necessary to add that it is also liable to produce many a curse from the tired sportsman, who is either patiently following the dogs or is "finding" his own birds. On no account is the burning to be left to the absolute discretion of the shepherd.

In regard to heather-burning, it may be added that if the moor is to be chiefly shot over dogs, the heather may be allowed to grow a little longer than in a moor used for driving purposes. In the former case it is more necessary to preserve good cover than in the latter, and there is no doubt that the radical heather-burning practised on a "driving" moor tends to make the birds wilder.

2. The Regulation of the Water-Supply.-There is no subject so much neglected by gamekeepers as that of the efficient water-supply of the moor. On the driest moor the keeper hesitates to be seen with anything but a gun, whilst during certain weeks of the year he should

1 A useful heather burner, sold by MacPherson, Inverness, is now on the market ; it answers admirably, and ensures a great saving of time and trouble compared to the older methods. 
carry nothing but a spade. In fact, it may be laid down as a general rule, that, omitting the pairing and nesting seasons, the spade should be a constant companion of the diligent and skilful keeper. Springs and streams need continual clearing to prevent the moor getting boggy and damp. Streams have to be dammed here and diverted there, so that an equal distribution of water may be supplied to the moor, for there is no greater handicap to the preservation of game than a deficient or an irregular water-supply. Every keeper should remember that this subject is as important as the burning of heather. It is a question upon which he will have to utilise as much brain as he possesses, for it is a matter that requires the careful application of varied methods to individual cases. Here, for example, is a spring that is absolutely clogged by undergrowth ; there is one that is obscured by heather and other overgrowth; whilst here again we find a stream that has too free a fall and that requires judicious damming, so as to supply the small pools which experience has taught to be necessary as water-troughs for the birds. It must not be forgotten, too, that a series of well-cleared and generously flowing springs adds much to the pleasures of a shooting party, and often indicates to the sportsman the competency and efficiency of the keeper.

Not only do the springs require attention and consideration, but the condition of the larger streams must be carefully inquired into. It may be necessary to divert the flow of a stream on to a tract of ground that 
requires water. It may also be required of the keeper to get rid of those many deep undermining pools, which are apt to form in the course of streams, and which are death-traps for young birds, not to mention sheep. The undermined parts must be filled in and the sides of the pool shelved. This should really be done by the careful shepherd, but he doesn't like the spade any more than the keeper. The question of the efficient draining of the moor is of equal importance. No definite laws can be laid down as to the nature and extent of the drains. Each case must be judged on its individual merits. Many keepers are apt in this matter to proceed upon some stereotyped line, and to miss the idiosyncrasies of the moors under their control. Drains should, as a rule, be wide and shallow, and should be formed with sloping sides. They should never be too deep. ${ }^{1}$ On no account must there be over-draining; but this is not a danger that need generally be feared. We have tramped over many a moor that has been swampy and boggy and besotted, and upon which we have observed the gradual disappearance of the heather, moors which were destined to become useless as breeding or holding ground for birds. All wet holes covered with green vegetation are most unhealthy both to birds and sheep, and should be drained. They are common in every moor, but with

I Deep drains may be "roaded," which is done by making an incline at right angles to the main drain, at intervals of a hundred yards. The "roading" is of assistance to the birds in getting to the water. 
a little care their disappearance is only a matter of time; their presence denotes a careless keeper.

3. The Elimination of Vermin.-This subject is dealt with in a special chapter by Mr. Tom Speedy, than whom no one can speak with greater authority.

4. The Suppression of Poachers.-The laws in regard to poaching must be carefully remembered. They are summarised in Chapter $\mathrm{V}$. The greatest care must be observed at two seasons : first, at the nesting season and for some time afterwards; and, secondly, just before the $T$ welfth, when marauders are apt to be abroad to procure an early supply of grouse for the market.

It is most essential that the moor be kept quiet and free from trespassers from 15 th April, when the birds begin to lay, until the time when young birds are able to fly. The keeper himself should have all his work on the moor done by the time the birds are laying, and should not cross it more than necessary, and never with dogs.

5. Feeding of the Birds in Hard Weather.-The stock of grouse on a moor depends to a great extent on the supply of food. In addition to plenty of young heather, grouse are very fond of blaeberries (bilberries); these should be encouraged to grow, and roots from woods and rough ground lifted and planted at intervals on the moor. Women and children should be prevented gathering the ripe berries on the moor. The artificial feeding of the birds in hard weather is a question that is not only considered as unimportant, but from what experience has taught us, seems a point 
that is absolutely neglected. Its necessity is chiefly found on high ranged moors, the tendency being for birds to emigrate to the lower reaches during severe weather. Mr. Stuart Wortley writes on this point: "It is quite worth while to feed them a little at such times. It is chiefly when the snow is caked or frozen over with a very thin coating of ice, and they cannot scratch through it to get food, that they are most pinched and may leave the ground, never to come back. I remember Mr. Walter Stanhope telling me that in the very hard winter of $1859-60$, the grouse on his Dunford Bridge moor left the grounds in hundreds. Many were killed in the fields in a half-starved state, and even one or two in the Barrack Square at Sheffield, some fifteen miles off. He then sent men up to the moor with long rakes, and as they raked the snow off, the grouse followed them close, as gulls will follow the plough. Your keeper should see to these methods of helping them to feed in severe weather, and not, as is too often the case, helplessly gape at the half-starved packs sitting on walls or scratching at the ground in the fields below the moorland, until, forced by hunger, they rise and fly clean away in search of milder conditions."

Of course, the feeding of the birds must not be carried out unless under dire necessity, for there is a probability of some uncharitable neighbour considering the action unsportsmanlike, in so far as it may draw away the birds from his moor. But there is not much danger of this misunderstanding taking place. Stooks 
of corn judiciously planted in the most desirable places is the best method of supplying food. It is an ill wind that blows nobody any good, and at such a time the keeper may be in a position to judge of the number of old cocks left on the moor. Their greed will be easily discernible, and an apparently mean advantage might be taken to rid the moor of these voracious, ill-mannered, domineering tyrants. It is a practice recognised by all experienced poachers, and it is well that keepers should learn from the skill of law-breakers. There is much to be learnt from rogues and vagabonds.

6. Introduction of New Blood.-The evil effects of interbreeding must be remembered, and there is much to be said in favour of the occasional introduction of new blood, either by interchange with other owners, or, in Scotland, by the purchase of Yorkshire grouse and vice versa. In putting down the new birds, the long feathers of a wing may be clipped or the outside long feathers may be soaped, which also keeps the birds from flying for eight or ten days, unless the weather is very wet. The most satisfactory method, however, is to pull two or three of the outside feathers off each wing. This keeps the birds on the moor for four or five weeks, till they get accustomed to their surroundings, and take up with the other birds. The new birds when they begin to fly, can generally be noticed in a pack by being behind and having a more laboured action in flight. Unless the birds by some method are kept on the moor, their usual tendency is a hom- 
ing one, and they generally make south for the moors from which they have come. Whether they reach there or not is another matter, but without some of these safeguards-the last-mentioned preferably-it is useless laying down grouse. There is, however, one very serious warning that must be repeated here. If birds are introduced from strange moors, on no account should they be purchased from suspicious sources. The important correspondence that took place some time ago in The Field as to the dastardly manner in which certain moors were depleted of their grouse by netting near the marches ought to make every true sportsman suspicious of the dealer in live game. I see no reason why a man should not rent a moor, and, instead of shooting it in August or September, leave it quiet till the end of the season and supply from it shootings which want fresh blood, and are willing to pay for it. Such sources exist, and the trade is openly carried on as a business in a perfectlystraightforward manner. My own experience of several importations of such birds is that a high percentage arrive safe and in good condition. It is necessary, however, to stipulate the proportion of sex when purchasing, and to get two hens to every cock. When laying the birds out on the various parts of the moor as far away from the march as possible, it is also advisable to note carefully the sex, keeping a record of the same in a book, to see that you have got what you have paid for. Otherwise you may be stocking a moor with a lot of old useless cocks, which will do 
more harm than good. This is a point seldom considered by keepers, who as a rule simply turn the birds down on the moor, and let them take their chance.

The principle of exchange of eggs between keepers is one which is most easily carried out, and the least objectionable, as a fair exchange is no robbery.

Considering the evils of the system and the difficulty of keeping the imported birds on the ground, it is better that eggs should be exchanged. One or two placed in each nest is the most reliable method of laying them down, though it entails more trouble to the keeper than placing a larger number in one or two nests; or they may be put under domestic hens. The hatching of grouse eggs under hens is very similar to that of pheasants. Twelve or thirteen eggs is the best number to set. A small hen should be chosen and the nest set in a clod of turf. Twenty-five days is the length of incubation. The coops should be placed on short heather, and after hatching they should be moved daily to prevent the ground getting foul. The same feeding should be given as to pheasant chicks, with a little variation, but not too much should be given at one time, so as to encourage the birds to take the natural feeding on the ground. They soon begin to take the tender shoots of heather and other plants, and, after a little study as to what agrees, and what disagrees with them, they soon thrive. Notwithstanding the fact that grouse are absolutely wild birds, they are easily reared, and are a most interesting study. When old enough to fly 
and take care of themselves, they should be at once moved to different parts of the moor, where they will soon become acclimatised. If left too long on the ground where they have been reared, they will continue packed there, in a semi-domesticated state, and refuse to move. The sooner they mix with the wild birds the better. It is absolutely necessary not only in the rearing of grouse, but of all other young birds, that they have a fresh supply of clean water several times a day, and that all dishes and utensils should be absolutely clean, otherwise they will be subject to contract disease. No food should be put inside the coops on any account, as it soon gets contaminated, and deaths follow. (See Artificial Rearing.) Another method is the exchange of coveys with moors eight or ten miles off. This method, however, is not to be recommended, as it sets a bad example to the countryside, and may lead to poaching. In July, when the coveys are fairly strong, the keeper should take a steady pointer (on a hot day when the birds will lie close), and, having located the covey, should throw a net over same. Carefully catch all the birds in the covey, and transport them in a basket, laying them down on a part of the moor, which, if it be at all possible, should not be shot over that year. Birds were transported from Ronachan in Argyllshire to Jura in this way with success some years ago. To all these methods, however, the ordinary keeper is averse on the score of trouble. He prefers to muddle along, and content himself with the consolation, with- 
out any jot of evidence, that birds fly from one moor to another, and thus keep up a change of blood. All evidence, however, tends to show the opposite-that birds keep to their own moor, and, if removed, generally return.

7. The Destruction, in the Autumn, of Old Cocks.This, one of the most important of the gamekeeper's duties, is nowadays so neglected as to be almost an unknown quantity. It is universally recognised that the presence of a large number of old cocks is in every way detrimental to a moor. Old cocks are pugnacious and quarrelsome, and they seem to take a special delight in interfering with the domestic arrangements of the younger birds. They are, in every way, undesirable tyrants. They drive the younger birds from their selected nesting-grounds, and thus interfere with breeding. It is on this account that so many authorities advocate driving as a cure for such ill-fated moors, although manyold-fashioned keepers are averse to driving. In driving, the old cocks are killed off in much greater numbers than in shooting over dogs, as it is a matter of the commonest observation that the old birds and cocks lead the packs, and it is an established fact that a driven moor generally gives better breeding results than a moor that is worked by dogs alone, for in shooting over dogs the guns are apt to take the nearest birds, which are generally hens. No better example of this can be found than the Moy moor, which is about I I,Ooo acres. When The Mackintosh started 
driving in $187 \mathrm{I}$, the bag was 2836 birds, while in 1893 it had risen to 4480 , in I 901 to 7 I 27 ; what it was over dogs before the driving began we are not told. But whether the moor is driven or dogged, the keeper should be allowed in the late autumn, after the systematic shooting days are passed, to take occasional walks over his ground and endeavour to shoot down as many old cocks as he is able. How much this precaution is necessary may be emphasised by an instance which came under the notice of the present writer in the month of January 1903. He was one of a party of guns in an improvised partridge drive in the county of Ayr, and in one of the beats, being an outside gun, he was stationed at the end of a field which lay on the fringe of the moor. He was surprised to find, as the beaters came towards the guns, that the air seemed filled with the calls of old cock grouse, and on looking to the right he could see them rising and going away every half-minute or so. The climax was reached when the beaters were entering the last field, when, instead of partridges, six or eight old cock grouse came over his gun. He hesitates to prophesy what the condition of that moor will be in a few years. When the tenant discussed the point with the keeper, the only reply he received was the futile one that he had tried for years to get near the cocks to shoot them, but not for a moment did the latter realise that their presence was a reflection upon his capacity as a keeper. This matter of the killing of old cocks is one of the questions upon 
which the owner of a moor is himself generally ignorant or careless, but every keeper who has at heart the prosperity of the shooting under his care should see that attention is paid to the matter.

Of course it must be understood that this shooting down of old cocks is no child's play. It requires both patience and skill. In the majority of cases the birds must be stalked. The stalker must go on to the moor alone, his trained dog being well under control, and behind him. He must proceed in absolute silence, taking advantage of any cover the moor may possess in the shape of old dykes and ditches. He will find that a well-choked barrel is best for his purpose, although it may even be necessary to use a rifle. He should never hesitate to kill the birds sitting. Some years ago on a moor in Strathtay, the present writer indulged in a series of these stalking expeditions, and he was very content, after a day's careful working of the ground, by creeping up burn sides, or crawling alongside old dykes, or often by coming upon his bird unexpectedly round a favourable knoll, to return at night with two or three brace of old cocks. He counted such a bag as of much more import to the future prosperity of the moor than if he had returned with a larger bag of younger birds.

But even despite all these stalking expeditions there is often left on the moor a large number of these unwelcome "chronics." Where there is much hilly ground, they are to be found on the tops in late autumn 
and winter, from which fortresses they descend, to the detriment of their younger brethren in the plains. Even where driving is not practised as a general rule, it is as well that one or two drives at least be arranged over these tops. Such drives are not easy to manage, but a competent keeper, keeping in view the general law of driving which refers to the customary flight of birds, and observing the point at which the old cocks come nearest to possible "butts," can select his stations accordingly. This is a matter worthy of the careful consideration of master and keeper, but it is a matter generally neglected on a "dogging" moor.

It is even to be recommended that the old cocks on the tops be regarded as vermin and trapped. If such trapping were carried out on the very high ground alone, there would not be much danger of harm coming to the younger birds.

8. Judicious Planting.-It is advisable, where there is little cover of the nature of forest growth or shrubbery near to the moor, that there should be a certain amount of planting on the lower parts of the ground to act as cover for the birds in bad weather. This is also beneficial to the sheep and cattle stock on the moor, as not only does it serve as shelter, but it gives a more luxuriant growth of grass and heather. On a windswept moor sheep and cattle never do so well, and require more food than on one which has good shelter, so that planting adds considerably to the value of the property and should be encouraged. 
9. Careful and Reasonable Control of the Number of Sheep.-A separate chapter is devoted to the relationships between keepers and farm tenants. It is only necessary here to emphasise three facts-(I) The one already referred to, that in no case must the heatherburning be left to the discretion of the sheep farmer ; (2) that shepherds' dogs must be kept under control in the breeding season; and (3) that the keeper should, if necessary, indicate to his master the palpable fact that the stock of sheep is too large and interferes with the feeding material of the grouse. Most moors are habitually over-stocked by the farmer, which condition is the chief factor in the high death-rate among sheep, as well as being highly detrimental, not only to proper shooting (especially when this is practised over dogs), but also to the food supply of the stock of game on the moor. When letting a farm a limit should be put upon the sheep stock. A clause should be inserted in the lease exacting a penalty of a rent of one pound per sheep for every one in excess of the stipulated number. A count of the sheep should be taken every few years at a gathering for dipping, in order to see that this clause is observed. When the adjoining land is well stocked with sheep, it is altogether desirable that the moor should be fenced off. Some of the best managed moors suffer not inconsiderably from the depredations of sheep from neighbouring lands. The feeding capacities of the moors under consideration may be, and in the event of there being only a small stock of sheep, 
are sure to be, better than those of the adjoining lands, and on this account the sheep will naturally migrate to the best grazing-grounds, and will as a result injure their feeding capacity. The moors will also be constantly disturbed by the shepherds' dogs driving back the sheep to their legitimate ground. Along the march of a moor which is not fenced, it is advantageous not to burn the heather, but to leave it long and rank. Where such a condition exists, the sheep will not stray across the march.

On the question of sheep and grouse moors $\mathrm{Mr}$. Tom Speedy writes: "Let us assume that there is a good stock of game, and the nesting season all that can be desired. About the 2oth of May hatching has commenced, and large broods are by this time following the parent birds. This is also the period for gathering the sheep, with the view of marking the lambs. Shepherds and their dogs are out betimes to the marches of their respective hirsels. The process commences, and the flocks are driven in a homeward direction. Eventually the shepherds meet and the sheep are concentrated in an immense flock, sometimes amounting to thousands, and driven towards the 'fanks.' Those who have witnessed the gathering of a flock as described, and have seen them driven in a solid line many hundreds of yards in width across a heathery hillside, must at times have speculated as to the probable fate of grouse eggs and newly hatched chicks. With this end in view, we have devoted many 
hours, accompanied by a dog, to the trail made by the flock, and have found both eggs and young game in large numbers trampled and destroyed. In the second week of June a similar course of congregating is adopted, for the purpose of clipping the old stock. Again, in the beginning of July, gathering is unavoidable for clipping the milk ewes." During these repeated operations the sheep are generally driven over the same route to the fanks. We strongly advise keeping the heather short on the route, so as to facilitate the progress of the lambs. The shepherds will always select this way, and thus be a cause of saving many birds. This is a point the shepherd should be consulted upon.

Damage is often done by cattle lying down on nests, and we have known the eggs of both grouse and black game destroyed in this manner.

I0. Improvement of the Feeding-Ground of the Birds by Introduction of Grit and Lime.-Grit is an essential and important part of the food of the grouse. It can be obtained by the birds in usually small quantities by the sides of streams and on other watercourses, but it will be found to the advantage of the moor, and the trouble will be fully repaid by the results, if a few sacks of lime and pounded shells be taken on to the moor every spring and deposited in suitable places.

I I. The Removal and Burning of all Dead Matter, such as dead grouse, dead crows, dead vermin of all 
kinds, but particularly the carcases of sheep.-It has been recognised from the earliest ages on record that nothing leads more to pestilence than leaving dead animal matter exposed to the air, and in contact with the food and water-supply of mankind and other living creatures. Accordingly, this recognised fact must be borne in mind by the keeper in dealing with any dead matter that may be found on the ground under his control. Dead grouse, dead crows, dead vermin, are dangerous enough in their power of contaminating the air, the soil, and more particularly the watercourses, but dead sheep are infinitely more capable of mischief, not only to living sheep, but also to game. It will be found, on careful observation, that a high death-rate of sheep is due to two causes-(I) To overcrowding, and (2), and more specially, to the presence of, or the effect of the former presence of, the rotting carcases of sheep. Some years ago an experiment was made on a certain moor in Scotland. The carcases of two sheep were left to rot in the open. After decay had well set in, two sheep (a two-year-old wether and a ewe) were temporarily fenced in at different parts of the moor, each sheep being given two acres of good hill ground. Both the sheep died within six weeks, and there appears to be no doubt that death resulted from their having eaten grass contaminated by the carcases of the dead sheep. In these latter days, when the destruction of vermin is carried out with some thoroughness, the ravens and hoodie-crows, the natural scavengers of the moors, have 
not the chance of making a meal off any sheep that may have died, and so the carcases are left to rot. Not only are the watercourses contaminated (courses which may be bringing water to the farms), but in wet districts great areas of the moor may be fed with decaying matter, to the detriment of the sheep farm, and, what is more important for us, to the grouse. The keeper should therefore impress upon the farmer the danger that threatens his stock by any neglect in removing this dead material. Shepherds as a rule, will laugh at this warning, partly from ignorance, but chiefly because a belief in it will give considerable trouble; but they ought to be made to meet the wishes of master and keeper on the subject. Keepers and shepherds should be encouraged to carry off all dead birds and burn them. The yearly present to the shepherd will be a reminder. A clause in the lease should be inserted compelling farmers to bury every dead sheep not less than $2 \mathrm{ft}$. under ground, and care should be taken that the grave be some distance from a watercourse. A penalty in a lease is a useful thing to make the tenant observe this stipulation.

12. The careful Bushing of Wire Fences, and the Placing of Metal Discs on any Telegraph Wires that may be near to the Moor.--The great mortality that of ten occurs from birds being caught in their flight by wire fences or telegraph wires is known to every keeper, and yet the means to counteract these evils are not consistently carried out. All wire fences that are likely to be 
in the line of flight should be "bushed" with heather, care being taken to see that the bushing is not removed. We have known instances of its removal by shepherds, one confessing to having picked up sixty grouse in one season along a line of several hundred yards. Notice should also be given to the Post Office authorities if it be found that birds have been killed by coming in contact with their telegraph wires. The authorities named will meet the wishes of the sportsman in having discs of metal put at intervals along the wires to warn the birds of their danger. In driving along a moor road in Argyllshire this spring, the present writer observed within half a mile three or four dead grouse and black game lying in the ditch side in the line of the telegraph wires, and on examination there could be no doubt as to the cause of death.

I 3. The keeping down of Bracken.-The increase of bracken is a serious matter in many moors. The best way to get rid of this pest is to cut the bracken down twice yearly with the scythe, when it is about a foot high, and before it seeds. If this is continued for some years it will die down, but if left alone it is certain to spread, and ruin the hill both for sheep and game. Another suggestion, but one which we have not had tried, is that of fencing a bracken area with grazing pigs, as it is said that they eat the roots. It might be worth while trying this experiment, as the bracken curse is a serious one. Constant cutting we think weakens the plant, and it is certainly thinner in districts under our 
notice. We have not, however, heard of any effectual cure.

\section{Artificial Rearing}

Excellent reports have been received from various sources as to the success attending the "hand " rearing of grouse. Game-hens, and sometimes bantams, have been used for the purpose, and the coops are placed on short heather, where a fresh shift can be got every day. "When the chicks are hatched," says Mr. Speedy, "they should at first be fed on hard-boiled eggs, with an admixture of 'Standard' meal, the makers of which have a preparation for the rearing of grouse and black game. Rice and seed may be added later, and maize - of which they are very fond-when they are large enough to swallow it. It is desirable to rear them in places where, besides heather, as much natural food as possible can be got, such as blackberries, cranberries, ribwort, bracken, etc. Hand-reared grouse keep well together during the autumn and winter months, and are easily known, so that they can be spared by the careful sportsman. On the approach of spring they spread over the moor and pair off to propagate their species, thus disseminating broadcast fresh blood over the district." No doubt some difficulty will be experienced in procuring the eggs of grouse. One solution of the difficulty is to obtain them from deer forests, where the removal of eggs would be regarded more as a benefit than otherwise. 
Shooting the Grouse

\section{Over Dogs}

There are several important points to be remembered by the keeper in shooting over dogs. Some of these are dealt with in the chapter on dogs, others may be recalled here. As to whether pointers or setters are preferable on a grouse moor depends largely on the moor, and how it is watered-setters require much water-but as a rule pointers are more steady than setters.

I. "Guns" must be kept in line, and should be warned not to walk too quickly.

2. Outside beats should be worked first, so as to drive in birds on to the lower grounds for the afternoon shooting.

3. The direction of the wind must be continuously studied, and the beats arranged accordingly.

4. A knowledge of the habits and habitats of the grouse must be taken into consideration. In the early morning the birds are found on their natural feedinggrounds - that is, on heather, three to four years old. On the approach of the dogs the grouse generally seek cover in the thicker heather near. After feeding-time they return to their roosting-ground, where they remain during the middle hours of the day. In the evening they return again to their feeding-ground, and after that, a little before dusk, return again to their roosting-ground. 
In very hot weather the birds frequent the sloping sides of burns and streams, or seek the cover of mixed bracken and heather, or shelter themselves among the bogmyrtle. In wet weather the birds ascend to the higher grounds. In boisterous weather they are generally found on the sheltered sides of hills.

5. Strict silence should, if possible, be maintained as the "guns" proceed. There must be no superfluous speech-making either to men or dogs. The attention of the guns should be drawn to a point by some simple ejaculation, such as "Mark, sir," or "Steady." The question of arresting the attention of the guns is important. Nothing is more tantalising to the keen sportsman than to be told in a casual, indifferent, languid voice to "Look to your right, sir," and to find that a bird has gone away some hundred yards before the sentence is completed. When a bird rises independent of a point, the keeper should call out emphatically, "Mark, sir," indicating "right" or "left" or "behind," as the case may be. Sound carries far on a moor. Nothing spoils sport so much as a noisy keeper, or loud talking by the guns. It puts all the birds on the alert, so that they are off before the dogs come to a point.

6. The ground should be worked systematically. Towards evening every piece of ground must be carefully searched. The largest bags of the day may be made when the birds have retired to their roostingground. 


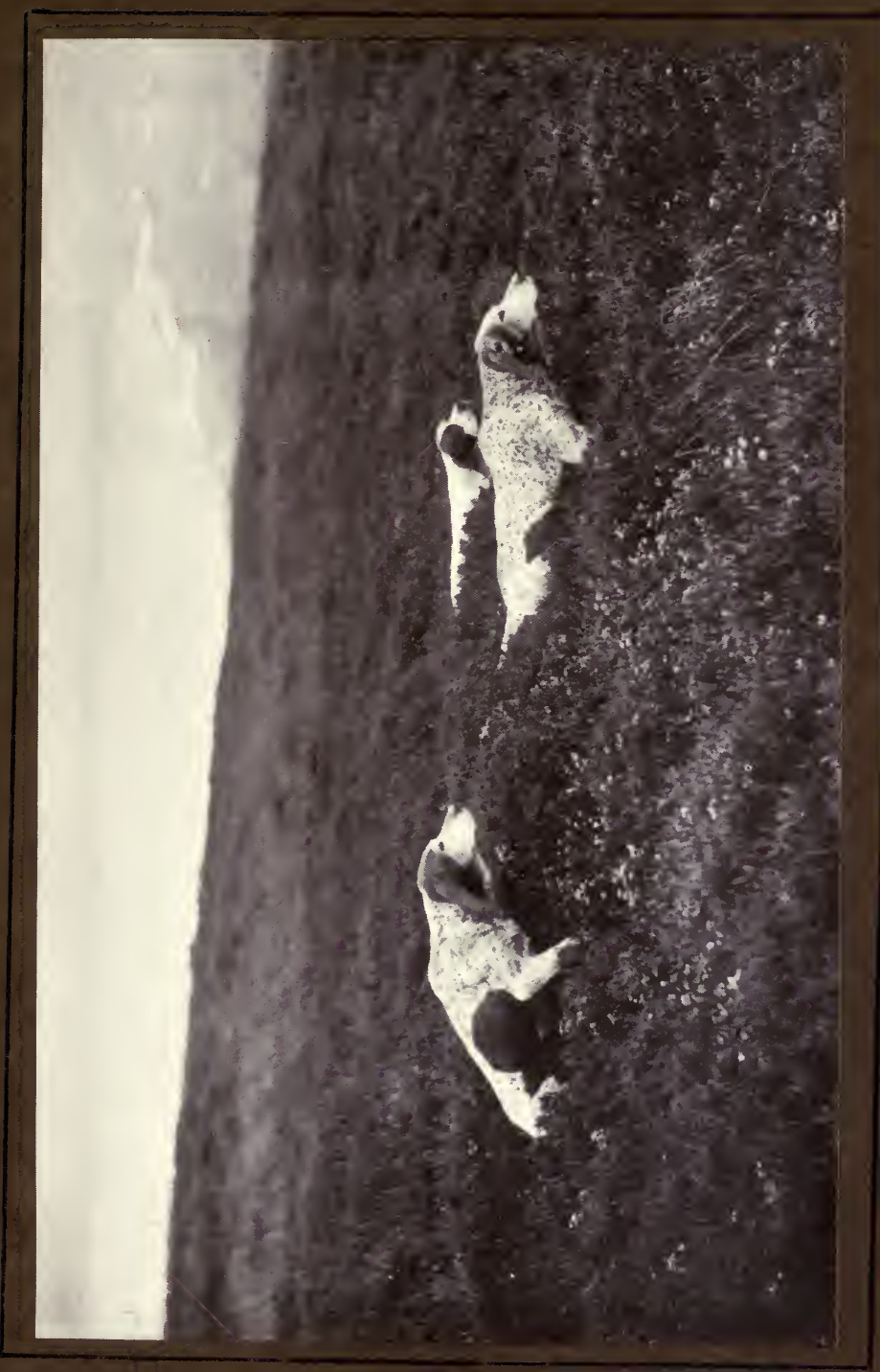

$\frac{3}{2}$ 
7. In addition to what is said in the chapter on dogs, the following points may be remembered :-

(I) Pointers and setters should not be overworked. To secure this, they should be changed at least every hour.

(2) It is best to have one man whose duty it is, primarily, to hold the non-working dogs in leash. This man should walk some eighty yards behind the guns, and should act as a marker for the flight of coveys and for fallen, especially towered birds. Where the number of men is limited, he receives the picked-up birds, and after carrying them for a sufficient time to allow them to cool, he hands them on to the man with the horse and panniers.

(3) Retrievers must be kept well in leash.

(4) If the scent is bad, the dogs must not be allowed to range too far, and the ground must be worked very slowly and carefully. If the point habitually fails, or if the birds are so wild as not to sit to the point at all, it is best to withdraw the dogs altogether.

(5) Plenty of time must be allowed for dogs to drink, but they must be discouraged from habitually taking to water. Where the ground is destitute of water and the day is very hot, water should be carried on to the moor for their benefit, in the panniers.

(6) Dogs should be given some slight refreshment in the shape of a sandwich at the luncheon hour ; never give a dog a game or chicken bone.

(7) It is as well, at the beginning of the season at 
least, to soak the feet of the dogs in strong brine or other hardening fluid, after the day's work. Plenty of exercise on the roads before the Twelfth hardens their feet.

(8) When a dog comes to a point, there should not be any " to-hoing " to it. If it has been properly taught, it should "hold up" without any words from the keeper ; an uplifting of the keeper's hand should be sufficient. If a dog has a habit of drawing too close on the birds, the keepers should come quietly to its side and hold it gently back till the guns are ready, directing of course, the attention of the guns to the point. If the dog be too slow in drawing on the birds after the guns are ready, it should be encouraged by patting it on the back or even by dragging or pushing it on.

\section{Driving}

The keeper's duties in regard to grouse-driving may vary from the conducting of several improvised drives on a moor that is free from butts, and which is chiefly "dogged" or walked or stalked, to the arrangement of systematic and elaborate drives. In preparing for the former little is necessary but a study of the wind, a knowledge of the general flight of the birds, and the selection of points which might be used as natural butts, such as dyke or burn sides, rocks, or the backs of the crests of braes and hillocks. In dealing with the business of an elaborate drive, however, he is concerned with a very different business and a campaign 
which will require most of his arts and all of his resources. But there are three important pieces of information, knowledge of which must underlie the whole of his plan of campaign :

(I) Accurate observation of the lie of the land. The keeper must carry in his mind a veritable Ordnance Survey map of the moor.

(2) The habits of the birds as far as the question of their customary flight is concerned.

(3) The principles underlying the forming, the marching, and the evolutions of the corps of beaters.

These three pieces of knowledge will lead him far to a successful outcome of the issue before him, which is how best to get the stock of birds over the guns. To successfully carry out a series of drives to their most perfect issue will, however, require not only careful consideration, but much elaborate manœuvring, and on this account he will have to take into his consultation, more closely than in most of his duties, the man who should know a great deal about the sport he wishes to enjoy, viz. his master. Besides this, the keeper, who desires to learn the art of grouse-driving thoroughly, must seek information of a more elaborate nature than this book pretends to supply. If he desires to bring his results-comparatively of course-to the perfection attained at Moy Hall, at Bromhead, at Gannochy, High Force, or Studley, he will buy or borrow from his master the writings of Lord Granby, Lord Walsingham, Sir R. Payne Gallwey, Mr. Tom 
Speedy, Mr. Horace Hutchinson, and Mr. Stuart Wortley,-more particularly of the last. All these writers deal with their subject tersely, simply, and graphically, and any intelligent keeper will rise from the perusal of these authors with a fairly definite view to the last and the best word on the subject. As we have said, we cannot pretend to deal with the matter on the principles of elaboration so excellently and vividly carried out by Mr. Stuart Wortley. We can only absorb the best views and present them with the modifications of our own experience.

Let us then further deal with the three points enumerated above :

(1) Accurate knowledge of the conformation of the land. From this knowledge the keeper will be able to lay the plan of his drives, so as to meet efficiency with economy of time and of space. He will learn what parts of the moor should be driven first, so as to keep the birds on the ground for future drives, and how best to work the moor so that the birds may be driven in from the outlying beats for the final flush over the guns. On hilly and rocky grounds he will discover where best to place the butts so that these different parts may be effectively worked. With a knowledge of the usual flights of the birds, added to the general information he possesses as to the lie of the land, he will be able to judge as to the best general distribution of the butts.

(2) It is only by continuous and careful observation 
that the keeper will be able to gauge fairly accurately the general direction taken by the birds in their flight. On this important information depends the question as to where the butts should be placed. Where driving is practised on a moor, the initial drives can only be regarded as experimental, and even when fairly accurate knowledge has been obtained, further experience may require the alteration of the position of the butts. The fact cannot be unduly emphasised, that no hesitation must be shown in making new lines of butts, or in shifting old ones. On many moors the butts of primitive days are treated like eternal monuments, not to be interfered with by any law or experience on earth. Truly these old stagers may be monuments-of ignorancebut quite useless for sport.

(3) The principles underlying the formation, progression, and evolution of the beaters. The art of driving is not easily learned, and the details are only perfected by experience. There are keepers who, despite the fact that birds are continually breaking back over the drivers or escaping at the flanks, persist with their primitive fashion of a more or less uncontrolled line of drivers, who are possessed with only three ideas, - firstly, to make their way by a bee line to the butts ; secondly, to keep in line with their neighbours; and, thirdly, to yell "Mark" whenever birds arise. Let it be reiterated for the hundredth time that the formation of the drivers should never be a straight line, but should be horseshoe-shaped, and that the length and the dis- 
position of the flanks must vary according to the ground and the direction of the wind.

Having enumerated the three main points which must serve as the basis of the keeper's knowledge, let us glance for a moment at some of the practical duties which are the natural outcome of this knowledge.

The first thing to be considered is the placing and building of butts. The practical points connected with this procedure may be enumerated-

(I) The butts must be placed in the general line of flight of the birds, which as we have shown, is discovered by the keepers, after careful observation from experimental drives.

(2) Butts should never be placed on the skyline. There is no exception to this law.

(3) Butts should be so placed that some eighty yards or so of gently sloping ground stretch in front of the guns, this ground constituting the main field of action. The best possible situation is just over a brae or small hill-the top of the hill being about eighty, and never more than a hundred, yards from the line of butts. But never, no never, on the skyline!

(4) Butts should never be placed where experience has shown that the birds usually fly too high for the guns-for example, at the bottom of a deep gorge between hills. Birds only dip their line of flight in traversing wide, shallow valleys. In passing over a deep gorge, they maintain their flight at the height of 
the first peak crossed, and will be out of range of the guns at the foot of the gorge.

(5) The distance between the butts should be regulated according to what experience has shown to be the width of the flight of the birds after concentration by the drivers and flankers. On level and undulating ground they should be closer than on rougher and more hilly ground. The old fashion of having butts at intervals of some eighty to a hundred yards is going out of vogue. The other extreme is practised by The Mackintosh at Moy Hall, where an allowance of only fifteen yards is made between the butts, on the principle that the concentration of birds is more marked than is generally believed, and that much good shooting material is thrown away when the butts are wider apart. This space is, we think, too little. The only objection made, to closely placed butts, has been the one of the possible danger of accident. Where the nature of the ground necessitates that one butt is out of sight of the proximate one, a stake, or better, a white stone, should be placed to indicate the fact of the proximity. This practice discounts any chance of temporary forgetfulness, which has been known to occur to the best of sportsmen. On rough and hilly ground the spread of the flight is wider, and here the butts should have a greater distance between them-a fair distance being fifty yards.

(6) Butts must be as invisible as possible, and, except in very rocky and very marshy country, practi- 
cally $2 \mathrm{ft}$. above the surface of the moor. The oldfashioned high-walled "batteries" should be in general discarded. The best way to construct a butt is to dig a hole in the ground with a diameter of some $5 \mathrm{ft}$. at the bottom and $6 \mathrm{ft}$. across the top. The "gun," in standing in the hole, should be just able to see and shoot over the slight parapet at the top, which should be almost flush with the moor, and never more than $2 \mathrm{ft}$. above its level, the outside being so arranged with heather turf as to slope gently up to the mouth of the butt. It may be useful, for the sake of firmness, to line the inside of the butt with wire-netting, and also the outside of the slightly elevated portion above the level of the moor. In the latter case the netting should not be exposed to view, but may be covered with a layer of heather-covered earth. About a foot in front of the butt a drain may be cut, which, if not too conspicuous, may be left open, or it may be covered carefully, so as to maintain its capacity as a drain. The draining of the butt itself is of importance. An opening in the butt with a drain which leads to a lower level than the floor of the butt will answer the purpose. The floor of the butt should be covered with wood. This ensures a fairly dry base for the shooter and his loader to stand upon. A board of wood supported on two posts as a seat at one side of the butt is also advisable. A stake may be inserted to tether a retriever.

(7) Butts should be well built, well drained, well in line, and kept in good repair. On no account must a 
very prevalent fashion be permitted to continue, of allowing the butts to take care of themselves, or leaving their repair to any energetic or practical hands that may exist among the "guns." How often, oh, how often! have we found ourselves crouching behind a small turf dyke, or in badly built, tumbled down, draughty, rakishlooking butts, flooded with three or four inches of water, from which we had to go scouring the land for stray slabs of peat or heather hummocks on which to kneel, for in no other fashion could we hide from view our cold and restless bodies. How we have shivered and groaned in these pits of stupidity and gross carelessness -built probably in the early seventies, and instead of growing dignified in their old age, sinking to a miserable decay under the dissipations of accident and weather. If we are not to have newly built, newer fashioned butts, then, in the name of all that is decent, let the keeper or his men patch up and drain the old ones, and save the "guns" from acute rheumatism, pneumonia, or shattered tempers. Let the "guns" at least have a chance of doing even their second best. It is on moors that are let to shooting tenants for short periods that such immoral neglect of duty chiefly prevails. Often it is the owner himself that is to blame. He knows he will have little difficulty in letting his shooting, and if he is not a keen or unselfish sportsman he is never particularly anxious for a lengthy lease of his moor. Accordingly in such cases the duties of a keeper are often allowed to slacken to an appalling extent, and in the decline of the sense of 
duty, the butts suffer first; - after the butts, the springs and the drains-everything, in fact, that seems to the lazy or half-stupid keeper to have little bearing on the number of birds killed.

(8) It has been suggested by some writers that the heather should be burnt for some distance round the butts, so that the birds may be found without difficulty after the drive. The two great objections to this are(a) That the butts would stand out more conspicuously than when surrounded by heather; and $(b)$ the birds are apt to be badly broken up in falling on to hard ground only protected by burnt heather.

\section{The Drive}

There are general principles in regulating the disposition and movement of the drivers which may be enumerated :-

(I) Where men are easily obtainable and it is proposed to carry out the drive in as complete and elaborate a manner as possible, two companies of drivers should be employed, one taking up their position at the far end of the second drive, ready to come forward as soon as the first drive is over, and the birds are picked up.

(2) In a first-rate drive there should be sixteen to twenty drivers, the best men being on the flanks. The centre man of the horseshoe should also be an experienced man, while, to save expense, the main curve of the hcrseshoe may be made up of intelligent boys. 
(3) If the head-keeper goes with the drivers he should be on that flank which it is necessary to control more, otherwise he may act as a stop; both ends of line of butts should be stopped.

(4) Drivers should walk slowly and silently, keeping their eyes open to receive directions from the man under whose control they work. There is no earthly use in yelling "Mark" when the birds arise-this only frightens them, and is apt to make them break back, grouse in flight naturally cling to the hill side.

(5) When birds arise and show a tendency to break back or to pass over the flanks, the drivers should quietly stoop so as to keep out of sight for the time, and then slowly rise again as the birds approach them. This plan is much better than the common one of shouting and gesticulating, and the probability is, if the former plan is observed, that the birds will sweep round in front of the drivers and go over the guns.

(6) In driving ground which is high on one flank and low on the other, the drivers on the lower ground should be a little more advanced than those on the higher ground.

(7) When there is a strong wind blowing across the drive, the downwind flanks should be well advanced. They thus form a screen to turn the birds. It may also be advisable to put more men on the downwind arm of the horseshoe, at the expense of the upwind one. It is really useless to attempt to drive grouse against a 
strong head wind, so that the drives of the day must be regulated by the direction of the wind, and not by rule of thumb.

(8) Different coloured flags should be used by the different members of the drive. For instance, plain white for the rank and file, red for the centre or head man, and red and white for the flank men and points.

(9) Drivers should come to a halt about fifty yards in front of the butts, and stay there till all the birds are picked up by the keepers and their dogs. When birds are flying towards the butts, the head-keeper should blow his whistle to give warning to the guns.

\section{Picking uP AND Packing of Birds}

(I) Where dead birds can be seen they may be picked up by hand before the retriever is loosened, but in doing so, care should be taken not to spoil the scent for the dogs by tramping all over the ground. On no account should beaters be allowed to pick up birds, for this reason-this should be left to the keeper, with his well-trained retriever or spaniel. The man who owns a well-trained spaniel or retriever should never go to a grouse drive without his dog.

(2) Birds should never be put in panniers and carts at once, but should be allowed to cool.

(3) The packing into the panniers or carts should be carefully and systematically carried out, the birds 
being put in singly, and so arranged as to form a compact mass.

\section{Hill Ponies}

In selecting ponies for hill work, whether for carrying panniers, deer, or men, the truism must be stated that the main point to observe is to select ponies that can climb. They should never be Lowland born or bred, and their chief qualifications should be strength and sureness of foot. They should possess these qualifications along with that of being good climbers, at the expense of speed, paces, and style, which should never be looked for. They should not be too small-size and substance is what is needed. The shoulders should have a moderate slope-this ensures sureness of footand breadth of loin and substance of bone should be demanded. In working the ponies they should be allowed as much as possible to have their own way, and to pick out their own stepping-ground. They should be allowed to go slowly. How often have we seen a pony fall, simply because the rider or the leader would persist in jerking its head backwards.

\section{Black Game}

There are a few facts as to black game which may be recalled for the benefit of the keeper "who does not know."

With regard to the stock, there are certain conditions which are conducive to a good supply of birds. 
(a) Delay in killing till the birds are in full plumage and capable of good flight, i.e. black game, except old cocks, should never be shot till the middle or beginning of September.

(b) Absence of vermin and plenty of rough ground.

(c) Judicious burning of heather and furze on the fringe of the moor.

(d) The neighbourhood of corn and turnip crop to the black-game ground.

(e) Killing of old cocks, as discussed when we were dealing with grouse. killed.

$(f)$ A limitation of number of grey hens to be

With regard to the time for killing black game, we think the keeper is perfectly justified in indicating to the ignorant or the very young sportsman the fact that it is a recognised rule, despite the present unsatisfactory state of the official close time, to leave young black game entirelyalone in August and the beginning of September. If a young blackcock gets up in August and trundles slowly away in front of the guns, the keeper should call out, "Ware blackcock," or simply, "Blackcock, sir." In the latter case, the tone of the voice indicates the fact that of course the guns understand that the bird is not to be killed.

As to the killing of old cocks, the keeper will recall what we have said about grouse. The old blackcock is equally as tyrannical and disturbing as the old cock grouse. No chance should be missed of killing the old 
cock, as black game are polygamous; you cannot be too severe on him. In attempting to rid the ground of these pests, the keeper has not the same difficulty, however, as in the case of the grouse. Black game are very conservative in their habitats, and generally select a particular spot for their fighting matches and carousals. The keeper will soon discover some place on the fringe of the moor where the birds congregate in the early morning. It will probably be an open space in some old wood, and, by getting up early and planting himself in cover, he will have an excellent opportunity of "potting" the old cocks. When the blackcock is to be stalked as it sits on the top of a dyke on the moor, it is to be recommended that, if the keeper is accompanying one of the guns for the purpose, he should take a different route from the latter, keeping far away from him and yet in sight of the birds, the gun in the meantime creeping up unobserved from an opposite direction. This practice distracts the attention of the victim from the main danger.

\section{Black Game Driving}

In driving black game there are several very important points to be observed-

(I) The drivers must be absolutely silent. This is even more important than in driving grouse.

(2) Like partridges, black game cannot be forced to fly contrary to their customary line of flight. On this account they are difficult to turn, and flank men are not 
of so much value as in driving grouse. However, the rule we have indicated, when speaking of grouse-driving, as to the drivers first stooping and then gradually rising as the birds come near, sometimes meets with success in turning the birds.

(3) The line of flight of black game is very constant. On this account, in driving a wood, the keeper is soon able to discover at what parts of the cover the birds usually pass out, and should place the guns accordingly. It is useless, as a rule, to line the guns at equal distances, as in grouse-driving. They should be fairly close together at the places indicated by the keeper.

(4) Black game will not drive well under the following conditions :-

(a) When all the corn is not cut.

(b) When the day is wild and blustering.

The best day on which to shoot black game is a dull, misty day when there is little wind. The mist hides the "guns" from the fine, long-ranged sight of the birds. High wind is apt to scatter the packs.

(5) The keeper should not hesitate, unless he is dealing with experienced black-game shooters, to remind the "guns" of two or three very important practices in black-game driving :-

(a) On no account should a hare, breaking away at the opening of the drive, be fired at, nor should the first birds, which generally come singly and are in all likelihood grey hens, be shot. This is an unvarying rule. To fire at these "scouts" is simply to set the 
whole army flying away in all directions, while, if these single birds are left alone, the rest of the pack will sail grandly over the guns.

(b) "Guns" must keep absolutely silent, well hidden, and as immovable as is compatible with nature.

(c) Of course the keeper must warn any very ignorant "gun" that grey hens must not be fired at, unless the stock is so great that it is desirable to reduce it.

\section{Poaching Black Game}

In addition to the general principles recognised for the suppression of poachers, long stakes, with a nail driven into the top at right angles, may be planted at intervals over the black-game ground, when poaching by netting is common. This practice is also valuable for the protection of grouse, but owing to the general limitations of the black-game ground, it is easier to carry out than in the case of grouse.

\section{Ptarmigan}

Every gamekeeper should be aware of the fact that ptarmigan are like woodcock in one respect. They always lie as to the wind. They are therefore to be found on the lee side of the hills. This fact is to be carefully recalled when they are being looked for. If, unfortunately, the march stretches along the summit of a hill and the wind is blowing from this side, the birds 
will be on the other side of the march, and there is not much use undertaking a mountaineering expedition to find them, unless the wise course is followed of arranging with the neighbouring owner or tenant to shoot ptarmigan on the same day. By so doing, the recognised method of killing ptarmigan will be followed, that is, by shooting in two parties. When the "tops" are on the keeper's own ground, the two-party principle enables him to get over the great difficulty of ptarmiganshooting, which lies in the fact that the coveys fly from one "top" to another. If there is a single party, the guns will have only one chance at the broods, unless they descend again to the "plains" and make another ascent to the other "top," which procedure is apt to become monotonous, even to the most vigorous sportsman.

It goes without saying, that there is no use taking out the guns on a misty day. In all forms of sport where there is thick mist, there should be no firing, and when on a fine day, the guns being on the "tops," mist begins to collect, shooting should cease. On this account it is to be recommended that in ptarmiganshooting the keeper and all the guns should each possess a pocket-compass. This, together with the fact that in all cases of difficulty one should follow the course of streams, will do much to counteract the disagreeable probability of being lost in the mist.

It may be necessary for the keeper to remind the young sportsman of the possible danger of not having 
his gun at "safe" while in the act of climbing or in groping his way over boulders and rocks.

The keeper should neither take with him pointers nor setters. They are inclined to be much put out by the presence of blue hares; but an old retriever is of the greatest possible value. 
NOTES 


\section{CHAPTER X}

\section{The Partridge}

OF the many services rendered to sport by Mr. Stuart Wortley, none can be valued more highly than the continued emphasis he has laid upon the fact of how neglectful has been the general attitude of the owner, tenant, and keeper in regard to the rearing and the preservation of partridges. Mr. Wortley, in discussing this important question, finds the explanation of the fact in the recognition of the pheasant as having the primary, often the only, claim to attention. Where pheasants are reared to any great extent, this is notoriously true, but there are other conditions, especially in Scotland, which have acted to the detriment of the breeding and protection of partridges. In the Highlands of Scotland the partridge has become almost a negligible quantity, not from any choice on the part of landlord or sporting tenant, but from the fact that the stock is so comparatively small that it is almost disregarded. The wet climate in the Highlands and West of Scotland, it must be admitted, is against the partridge doing well. The soil is too barren, and in many cases too heavy. A warm, sunny exposure, with a small rainfall and light 
soil is ideal for partridges, so that for a first-class partridge shoot we must look to England or the fertile parts of south-east Scotland. They require arable land, which is fast going out of cultivation, and a certain amount of rough waste ground on the fringes of the arable. A new danger seems to have developed, which some say accounts for the scarcity of partridges in districts where they were once plentiful, that is, the higher cultivation of land, and the great increase in the use of artificial manures. As against the increased fertility of the land, partridges as a sport must take their chance and come second. In many districts in England it has been noticed that dead birds have been found to contain arsenic in their crops. How do we account for this? It looks as if the only source can be the artificial manures which are used for keeping up the fertility of the land. If this be the case, there is no remedy. Another contributory cause, in some cases, is the number of rats on the estate, which vermin are undoubtedly severe on eggs. May it not be that the destruction of hawks, stoats, and weasels by the keeper, with the best intentions, has allowed the balance of nature to increase in favour of the rats, which are usually kept down by those other vermin. One other serious factor in this connection is the trapping of rabbits in the open by farmers in summer around the young corn. A large number of pheasants and partridges are undoubtedly killed in this way, so that, the eggs and young being left without a protector, a large shortage in stock is bound 
to take place. It is illegal to set traps in the open, and the law should be firmly set in force without any fear of incurring the displeasure of the farmer. $\mathrm{He}$ is in the wrong, and to overlook this is buying his goodwill at too high a price. The more you give in, the more a farmer will take advantage of you, but if he is a decent man at all, and you have his goodwill, he will at once, on his attention being drawn to the matter, stop the practice. If he does not, such goodwill as he has to give is not worth having, and you had better have all the rabbits killed down in winter. In this instance it is not the pheasant that serves as the unwilling cause of offence, but the grouse. As in the case of large covert shoots in the south, so in the case of moors in the north, the keeper has been (metaphorically speaking) in the past, and seems likely to be in the future, a snob. The pheasant and the grouse he regards as high in the social world of the bird, and worthy of pampering and adulation, whilst the poor vagabond partridge is left more or less to grub for himself.

The blame for this condition of affairs, of course, reflects to a marked degree on the owners or tenants themselves, but does not entirely release the keepers from their responsibilities. Many sportsmen only stay at their shooting boxes as long as they are able to get sport on the moors, and return south practically indifferent to the fact of the possibilities of good bags of partridges from the cultivated land that stretches down the strath in front of their very lodge doors. And even 
when this indifference is not so marked, there can be no doubt that the general run of sportsmen would prefer to bag their ten or eleven or even their four or five brace of grouse in the late season, with the joy of a tramp on the hill, than spend a weary day, dragging their muddy boots through wet turnips and potatoes, with the prospect of a larger bag of the autumn bird. This is but one side of the question. There is a more important reverse. Many sportsmen in the Highlands of Scotland are indifferent to partridge-shooting, not because of the more absorbing claims of the moor, but because of the general poorness of the partridge stock; and such being the case, and granting, of course, the necessary ground conditions, the blame is to be laid largely at the door of the gamekeeper. Our present readers, with their sporting imaginations stimulated by a fine picture of well-cultivated agricultural land, stretching from the edge of the moor, in rich variegated tints, down to the edge of the river, wending its rapid way through the spirals of the strath, and interrogating the head-keeper as to the prospects of partridges, have had their imaginations often curtailed by being told in an indifferent tone that there may be a few coveys, but nothing to speak of. And such information has been conveyed to them as if the fact finally settled the responsibility of the keeper. Let it be our duty to emphasise the fact that it has only determined the existence of wilful neglect of opportunity on the part of the sportsman, and the absence of a due sense of responsibility 
on the part of the keeper. If there be good partridge ground, the partridges ought to be there. If there be none, or if there be only a poor stock, it indicates an indifferent sportsman or a casual keeper.

Of course these remarks are made with a full recognition of the fact that the keeper's department may be undermanned. But that fact is to be taken into account in all we have to say as to the keeper's duties. But we intentionally leave out of account those rare cases where one keeper has perhaps in his charge a fairly extensive moor, a rabbit warren, and several stretches of good cover, and whose time is fully taken up on these preserves, trapping, draining, and watching. Such conditions, being rare, need not trouble us. It cannot be said, as a rule, that keepers are overworked. Their duties and responsibilities are great, and there is no more popular fallacy than to imagine that their occupation is but a very pleasant form of an idle country life. But the care and protection of a stock of partridges, although requiring considerable time, patience, and skill, need not prove irksome to any keeper who is at all interested in his profession.

In the majority of cases the partridge ground is at his very door, and more easy of control than the moor, which may stretch miles beyond his immediate circumference. And although such be the case, it is a notorious fact that on many shootings the information one can obtain as to the number, position, and condition of partridge nests and eggs is lamentably poor, and a 
desire for specific information is dismissed by a few inconsequent and often misleading general statements. And it is curious to observe how glibly the indifferent keeper will, season after season, talk of the drowning of the young birds and of the smallness of the coveys, apparently indifferent to the fact of the ways and means to counteract these conditions. In the case of Highland shootings, the keeper, perhaps, is not so much to blame as the men whose care is chiefly with a semi-wild bird of the hand-reared pheasant type. The imagination of the former may be stunted by the fact that his work is chiefly with birds which, to a marked extent, look after themselves, and which receive but slight artificial assistance compared with the hand-reared pheasant. But although this be a fact, it ought not to serve as an excuse, and it will be the first duty of the sportsman who realises the possibilities that he may have missed, to remind the keeper of the artificial processes that are necessary for the proper rearing and care of a good partridge stock.

Having said so much in regard to the partridge ground attached to shootings where the moor is the first consideration, we return to the conditions to which Mr. Stuart Wortley has specially directed his remarks. "Most English manors," says this great authority, "have not anything like the stock of partridges which they ought to produce. This I attribute to three causes. First, the keeper's work is not, as far as partridges are concerned, well understood or properly carried out. 
Second, which is a result in part of the first, there is a good deal more egg-stealing and poaching than there should be. Third, the stock, being low, is too much reduced by hard shooting." In dwelling on these facts this writer selects a particular shooting, "The Grange," to illustrate how the partridge stock may be improved, and dwells at length on some of the practices observed. "The high average maintained at The Grange is due to a combination of . . . conditions (favourable) and the system on which the keeper's work is conducted; and it is here that I think a lesson may be learned by other owners and keepers. First and foremost, the latter are taught to treat partridges, and not pheasants, as the first consideration. Partridges require a better and more watchful keeper than pheasants. The old-fashioned system of leaving partridges to take care of themselves in the nesting season, while your keepers are devoting themselves exclusively to the pheasantry and the coops, must be abandoned. Everything must be done to watch and thwart egg-stealers and poachers. To arrive at this, it follows that the whereabouts of every, or nearly every, nest must be known, and these must be watched and visited practically every day."

The rule which we have printed in italics must serve as the basis of the keeper's conduct. In no other way will he be able to attain to satisfactory results. To those who have become accustomed to the go-as-you-please philosophy, this may seem at first an irksome addition to their day's work, but we are 
concerned, not with the likes and dislikes of keepers, but with their duties.

As in dealing with the question of moors, we may categorically enumerate the various points that must be regarded by the keeper for the proper preservation and improvement of his general stock.

(I) The supply or improvement of cover.

(2) and (3) The careful watching and protection of eggs and nests and artificial rearing.

(4) The improvement of the stock by the introduction of eggs from other districts, and the importation of foreign partridges.

(5) The destruction of vermin.

(6) The suppression or the frustration of poachers and poaching.

(7) A tactful understanding and sympathy with the farmers.

(8) The killing of old cocks.

\section{Cover}

Many estates are fortunate enough to possess so much well-distributed cover as to call for little innovation of a radical nature. Some are ideal in this respect, the various fields of potatoes and corn being flanked and intersected by rough ground of broom ("whin ") and gorse, with here and there additional growths of birch, juniper, and other classes of trees. How notoriously this kind of cover is used by partridges can be proved by the fact that on the first of September in Scotland, 
long before the crops are cut, small bags of partridges are to be obtained by simply walking through these patches of cover. As a rule these strips of "rough ground " are considerably elevated above the cultivated land, and in preparing artificial cover based on the principle of their construction, the question of elevation must not be lost sight of. In proceeding to lay out this nesting cover, common sense must be used in distributing the patches of ground equally about the estate, avoiding, if possible, too close proximity to the pheasant coverts, which must naturally be kept as quiet as possible till the day of the first shoot. In preparing these strips of cover, or banks, it is as well that considerable care be taken with regard to judicious sowing. If the banks be sown with young broom and left unwired, there is a likelihood of the young growths being eaten by rabbits, hares, and foxes; but if the wiring be too high, there is a danger of the hen partridge not being able to get her young brood on to the slopes of the banks on those occasions when stormy wet weather urges her to seek protection for her young. This remark only applies, of course, to the very early days in the life of the covey ; but it is important, nevertheless, for it is at this very stage that young birds are apt to be washed away by driving storms, or to be drowned in ruts and furrows. With regard to the depredations of foxes, $\mathrm{Mr}$. Wortley rightly points out that "they will not be entirely kept out by wire-netting after it has been up a year or two, but they will always be loath to trust them- 
selves much inside it, and any little alteration, such as an extra strand of wire along the top, will make them suspicious of a trap, and in all likelihood keep them out altogether."

It seems necessary to point out here, what seems to have been omitted by most authorities, that the cover must no more be allowed to take care of itself than heather on a moor. It will require from time to time judicious pruning, supplanting, and replanting, so as to maintain its value as a feeding and rearing-ground. It is not necessary to add, after the observations we have made, that, in this consideration at least, rabbits and hares must come under the category of vermin and be treated accordingly.

The question of expense will naturally arise in dealing with this matter of sufficient cover for partridges. In many cases the owner will be satisfied with a considerable improvement of the existing cover, in fewer cases he will be prepared to meet the outlay necessary for the planting of new ground, and where expense is no object he may advocate the laying out of sanctuaries or preserves. These may be as elaborate as the covers at Sandringham, or may simply consist of stretches of corn or rye plantation preserved in the midst of other cover for the special use of the partridge.

2 and 3. The Careful Watching of Nests and Eggs and Artificial Rearing

We have already laid down the ideal principle for 
the protection of nests and eggs from the depredations of poaching. Any slacker method can only lead to disastrous results in so far as the size of the coveys is concerned. Egg-stealing is a very profitable business, and is conducted with ease, owing either to the carelessness or the dishonesty of the keeper or his underlings. This carelessness is a form of neglect of duty that should bring any self-respecting keeper to his senses, and if not, should bring him to the rightabout. Of course, as in other matters, the criminal neglect of duty by the keeper is merely a reflex of the casual indifference of the master-here, again, we touch on a matter of explanation, but not on a matter of excuse. In the matter of the depredation of nests and eggs the keeper has to deal with six types of enemies, each of which must be watched closely and frustrated. These are-(I) vermin-including foxes, (2) farmers and farm labourers, (3) casual poachers from neighbouring villages, (4) professional poachers, (5) stray dogs, and (6) mowing machines. Each of these enemies is dealt with in individual chapters treating of the specific subject concerned. As for the general habits of a great number of keepers, all that is done to prevent the stealing of eggs and the poaching of young coveys seems to be an occasional sleepy stroll slantways across a field that may contain six or seven nests or young broods, and the occasional slipshod "bushing" in the grass fields. Every corner of every field should be gone over carefully at the beginning of the season, until a 
thorough knowledge of the whereabouts of nests and the number of eggs be obtained, and then the rule followed as to watching, which we have printed in italics. Any diminution of the number of eggs must be carefully noted and the cause traced to its source.

With regard to the protection of partridges and their nests, it must be observed, in addition to what is said in the chapter on vermin, that the destruction of the latter is naturally easier in cover which is not too redundant. Accordingly, the "rough ground," "the whins," the banks, and the fences must be loosely planted. If already thick, they must be thinned out. Trees and shrubs must not be too closely planted together. In other words, shelter, or, as it is termed, "cover," must be sparse and well distributed,full of young vegetation, and well protected from vermin. Where nests are found in the open, it is recommended that " a single strand of wire, about ten inches above the ground, be stretched from stout pegs." This will prevent any fox from crossing the field. Bushing must be carefully attended to, the bushes being liberally distributed and well planted, and careful observation made of any tampering with the position in which they were first placed. The attention of the factor should be called to see that the farmers keep their ditches cleaned, as otherwise, in times of flood or spate, water does not get away, and is apt to flood out the nests. Keepers should prevent the birds from nesting in ditches so foul with undergrowth that water cannot get free flow. 
After any rainstorm, or during it, if necessary, the keepers should be out and making observations as to the safety of their nests and small coveys. Some artificial help is often necessary to protect the eggs from destruction, and a wise keeper will often discern a chance to interfere for the benefit of his broods, although it must be remembered that human interference is soon detected by ground vermin, especially stoats, and the future safety of the eggs may be in peril. "If a sad mishap," says Mr. Macpherson, "has befallen a clutch of eggs, and some of the number have actually come to grief, the misfortune can best be redeemed by such eggs as happen to have escaped destruction being placed under the charge of a domestic fowl. When the little fellows emerge into the world, they soon learn to take care of themselves, but the pupæ of ants are requisite for their successful rearing." For it is notorious that the hen bird hesitates to return to her duties if her nest has been partially destroyed or interfered with. That distinguished observer, "A Son of the Marshes," indicates in the Pall Mall Magazine ${ }^{1}$ the methods of procuring the pupæ. "Two very different kinds of ant-hills supply the eggs or ant-pupæ to the young of game birds, and of partridges in particular. First, there are the common emmet-heaps or ant-hills, which are scattered all over the land; go where you will, you will find them. These the birds scratch and break up, picking out the eggs as they fall from the light 1 Pall Mall Magazine, 1893, p. 737. 
soil of the heaps ; the partridges work them easily. But the ant-eggs proper-I am writing now from the gamepreserving point of view-come from the nests or heaps of the great wood ants, either the black or the red ant. These are mounds of fir needles, being in many instances as large at the bottom in circumference as a wagon wheel, and from 2 to $3 \mathrm{ft}$. in height--even larger where they are very old ones. They are found in fir woods, on the warm, sunny slopes under the trees, as a rule, pretty close to the stems of the trees. The partridges and their chicks do not visit these heaps, for they would get bitten to death by the ferocious creatures. The keepers and their lads procure the eggs of these, and a nice job it is! A wood-pick, a sack, and a shovel are the implements required for the work. Round the men's gaiters or trousers leather straps are tightly buckled, to prevent, if possible, the great ants from fixing on them, as they will try to do, like bulldogs, when the heaps are harried. The top of the heap is shovelled off, laying open the domestic arrangements of the ant-heap, and showing also the alarmed and curious ants trying to carry off their large eggs to a place of safety; but it is all in vain! Eggs and all, they go into the sack. In spite of every precaution, the ant-egg getters do get bitten severely, for the ants would fix on anything. They spit, as the men term it, their strong acid venomously. . . . These heaps are harried for the home-bred birds-that is, home and hand-fed ones, both pheasants and partridges hatched 
by small game-hens-game-fowl kept specially for that purpose-from the eggs that have been taken from the outlying nests." Or, as we have shown, from the destroyed or partially destroyed nests. "Other strains of the domestic fowl are used, but the game-hens are the favourite foster-parents. When the birds are fed with the eggs, as many of the ants as it is possible to get rid of are kept out; but some are sure to be mixed up with the eggs, and these fix on the birds, making them jump off the ground. The common emmets, the creatures that the wild birds feed on-their young broods particularly - are harmless, but the large wood ants are not."

But it is strongly to be recommended that the chicks which have been placed under the care of the gamehen should be transferred as soon as possible to a brood of partridges of much the same age as the chicks. Artificial rearing and feeding presents many difficulties and risks, and there is no difficulty in the way of a parent partridge receiving the little strangers into her home, granted that the domestic hearth is not already too crowded.

For the guidance of the keeper it might be useful here to summarise the circumstances under which he is entitled tolift eggs and transfer them to the game-fowl:-

(I) In those cases where a nest has been disturbed by a dog or a casual intruder, and there is a reasonable fear that the parent partridge may desert its nest.

(2) Where the parent birds have been killed or I4 
frightened away either by mowing machines or by other intruders.

(3) In cases where the eggs are found nested in positions of danger, or where in the judgment of the keeper they are lying in too exposed a position.

(4) In cases where two hens have laid in the same nest and quarrel as to the right of taking sole control of the eggs.

There are circumstances where a very careful and observant keeper may be able to say definitely that certain eggs have just been laid. If he can trust to the accuracy of his knowledge in such cases, and if he be faced with any of the four conditions mentioned above, he may transfer the eggs to the nests of other birds which have not begun to brood, and which have not already their full supply of eggs-that is to say, not more than eighteen or twenty.

The eggs for artificial rearing may either be eggs collected from the nests of partridges on the estate, or may be bought from recognised English game farms. In the former case it is sometimes necessary, in the latter always so, to test if an egg is still fertile. This is done by putting the egg into water. If still fertile it will sink to the bottom of the vessel used, if addled it will float. It will be observed that occasionally the larger end of the egg tends to point upwards and not to be quite flat at the bottom. This indicates that the egg is rather stale. The old adage may be quoted, The fresher the flatter. 
When the eggs have begun to chip they should all be removed to the incubator, except two or threenever less than two. When hatching has taken place, the chicks are put into the drying-box, but not kept there very long before removal to the game-hen who is acting as foster-mother. It is wise to see that the hen is well fed before she receives her hatched brood. Chicks should be carefully turned into the coops at night time. After six weeks of artificial feeding they are turned into the cornfields.

Attention must be drawn here to the practices which have proved so successful at Sketchworth Park. They are described in detail by Mr. Argus Olive in Country Life of 14th November 1903: "The partridges are allowed to go on laying until they have started to incubate their eggs, then about the third day of sitting their treasures are removed from them and sham eggs are given in their places, so that the birds continue to sit until their own eggs that have been put under hens are chipped. The process is not completed until twentyfive of these chipped eggs are brought to the sitting partridge, whereas probably only fifteen or fewer were taken from her. She is easy enough to deal with, and if she objects to the hand that introduces the eggs and takes away the sham ones, she will not move more than a yard or two, and will come back directly she is allowed to do so.

"It is not supposed that she would, from the start, incubate twenty-five eggs, but it is a different thing 
when the young are so far self-sustaining as to be able to chip the shell; and it has been known, even before the period of the process of incubation, that a desertion and absence of outside heat for twenty-four hours has not killed the embryo. At any rate, without arguing the case, the hen partridge does hatch off these twentyfive chipped eggs. It will therefore happen that three old birds will care for all the eggs of five, so that two birds out of five are not kept sitting upon sham eggs, but have their nests destroyed. The object of this is that they should start laying again, and in order that this should be certain, these two are robbed before incubation begins, for it is a questionable point if partridges that have once become broody very often lay again; if they do, how early or rather how late they do it. Personally, I do not believe many ever lay again that season if they have once started to sit. At any rate, the risk is not worth running, and as these two birds will each be good for about eight second nest eggs, if the first are taken in time, the moral is obvious. In practice, this seems to be the utmost improvement that has proved successful. Its gross result for the five birds may be stated thus-Safety from thunderstorms and from vermin for the incubating eggs, and besides, ninety-one eggs instead of seventy-five for every five birds."

Feeding of the Young Birds. -We have already spoken in former paragraphs as to the feeding of the young chicks which have been placed under the care 
of a foster-mother. It is only necessary for us to add a few remarks here on the general feeding of the young partridges when they are reared artificially.

It is essential that the young partridges should have a good supply of the pupæ of ants during the first fortnight after hatching. When these are not obtainable, Mr. Carnegie recommends bruised wheat soaked and then fried. "About the third or fourth day, some custard may be given mixed with lettuce, chickweed; plantain (the unripe flower), groundsel, rice, broken small and boiled, and small quantities of any small birdseed. The best way is to make a thinnish custard, and mix some of the other food material with it, always giving preponderance to the green food. Any insects which may be obtainable may also be given, in addition to the ants' eggs, which, it is necessary to remark, ought not to be offered the chicks till the other food has satisfied their appetites." "Boiled rice, custard, or hardboiled eggs," says Lord Walsingham, "well crushed, will certainly ensure the saving of a fair proportion of the chicks; but these alone are by no means equal to the same with the addition of ants' eggs. It is a good plan to sweep the rough herbage on the borders of some neighbouring field or wood with a coarse bag-net made of canvas or calico on a stiff iron hoop fixed on a strong handle. By this means a large number of insects of various kinds are easily collected, and can be conveyed in a bag to the coops, and thrown down for the birds. When the birds are three weeks or a month old, the 
same food that is given to young pheasants may be provided for them, but grain should in no case be given, unless first soaked and crushed."

The coopsforartificially fed partridgesarebest placed in fields where the grass has been cut. The young chicks are then able to take advantage of the new grass as it grows. The coops should be moved daily, so as to ensure a new feeding-ground, with its potentialities of grass and insect life. A supply of water is necessary for all partridges, whether artificially reared or in a wild state, and it is as well, in a great drought, to distribute small drinking-troughs over the estate. In this way the lives of many young or even old partridges have been saved.

In making these remarks on the artificial rearing of partridges, it is only necessary to add that it is much more important that the keeper should give his time and sense to the careful watching and protecting of the wild birds in the nesting season, than that he should be concerned in the processes above described. Very few sportsmen go in for artificial rearing, and it is practically unknown in Scotland.

It is not intended in this volume to attempt to describe the various methods of hand-rearing partridges. The French or Continental is the principal one, the others being modifications to suit the surroundings and climate. The advantage of more natural surroundings, and the use of the parent birds, is undoubtedly of great value. The subject is one which will require a small book to itself, and we would advise those intending 
to take up the French system to buy one of the pamphlets which devotes itself entirely to such details.

4. The Improvement of the Stock by the Introduction of Eggs from other Breeding-Grounds, and the Importation of Foreign (chiefly Hungarian) Partridges.

In many instances nowadays it is to be feared that sportsmen expect too large a bag of game-they are not content with the bags of half a century ago. The constant attempts to make ground carry a larger stock of birds than Nature intends it to, is creating an artificial situation, and this has many risks, and must tend to disappointments. If these are to be avoided, the sportsman should try to gauge the stock of game his land will reasonably carry with fair attention and feeding.

Enough has been written with regard to the criminal abuse of the practice of buying eggs for the purpose of improving stock, and it is again referred to in another chapter. Far and away the best method is to obtain the eggs from a friendly sportsman. Rather than buy eggs from strangers, it is better to lay down Hungarian partridges or buy Hungarian eggs. This remark, of course, is made with the object in view of counteracting the dishonesty that is apt to be associated with the trade in eggs. It is most necessary to state that eggs obtained, for the purpose of being placed in the nests of parent partridges, must be freshly laid; if incubation has com- 
menced, they are best dealt with under foster-parents. For the improvement of the breed of stock, an interchange of eggs is made recourse to, either simply by transferring eggs from brood to brood on one's own ground (where this is extensive), or by dealing with a friendly neighbour. A similar interchange or transference of birds may be recommended. On one's own property birds may be captured, while at feed, by coops. Two out of three cocks should be killed and the remainder removed to the ground indicated. Here they are kept under coop for a few days, fed sparingly, and then turned out. The same process is followed when exchange is determined on with birds from neighbouring properties or from a distance.

With regard to the introduction of Hungarian partridges a few remarks are necessary. They should be turned down sparingly-a few every year. On this point Messrs. Tudway and Hall write: "The earlier they are turned down the better. Birds should always be turned down at night, in the neighbourhood of their water and food supply. If this does not exist, supply both. On the night that the keeper turns them down, let him first separate the sexes, and then place about four hens in one spot, and the same number of cocks at a distance, repeating the process while the birds last. This will give them the chance of mating with English birds the same season."

The practice which is followed by the present writer, who has for years dealt with Hungarian partridges; is 
as follows: He erects enclosures-each $8 \mathrm{ft}$. by $5 \mathrm{ft}$.- -at various parts of his partridge ground. The enclosures are about $3 \mathrm{ft}$. high, and are made of wire-netting fixed on stout poles, covered at the top with packsheet to prevent the birds hurting themselves in their attempts at flight. One end of each enclosure is movable, and is virtually a wired gate. Inside and all round each enclosure are placed fir branches, which act as excellent cover. From six to eight birds are placed in each and are fed on barley and hay seeds for eight days. At the end of that time they are settled down. Food is then scattered outside of the enclosures, and on a dark night the "gate" end is opened: Lord Walsingham's modification of this plan, as far as it affects the letting out of a few birds at a time, is probably an improvement.

But whatever method be adopted, on no account should the practice-which we have observed on more than one occasion-be followed of letting the birds out on the night of their arrival and after being hustled about for days in the process of travelling. Where such a procedure is practised, the birds immediately. take flight, and, flying hard, fall exhausted many miles from where they were laid down.

The questions of (5) The Destruction of Vermin, (6) Poachers and Poaching, and (7) The Good Understanding with Farmers and their Employees, are dealt with elsewhere. It is only necessary to comclude this part of the subject by referring to the question of the 
killing of some of the cock birds, which are nearly always in excess of the hens in each covey. The keeper should get the consent of the master to kill a few cock birds at the pairing season.

Note.-It has been recommended by some authorities that at the pairing season the keeper should scour the grass fields and drive the birds into the corn fields, so as to urge them to make their nests there instead of in the more exposed grass or lea fields.

\section{Shooting the Partridge}

Walking up.-In shooting partridges by walking them up, pointers and setters are used in those cases where there is not too large a stock of birds and where economy of time and energy is desired. In the majority of cases, however, they are dispensed with. Some of the main points to be remembered by the keeper in the shooting of partridges by the walking-up method may be enumerated :-

(I) It is very advisable, before the shooting commences, that the stubble and lea fields be well beaten in the early morning, for the purpose of driving the birds into the covers of potatoes and turnips-the former for preference. The keeper should send out boys for this purpose, or he may gallop on a pony over the fields, driving the birds in and noting their destination.

(2) A good deal of time will be saved, and a large amount of important information gathered, if a marker or markers be posted on high vantage grounds to note 
and indicate the flight of coveys. Any piece of high ground near to the scene of action may be used for this purpose, or the marker may even use a tree from which to "look out." Even when hands are scarce it is better to utilise a marker at the expense of the number of beaters and attendants than to dispense with him altogether, unless the lie of the land be such that he is either useless or superfluous. This will be found a very exceptional condition of affairs. There must be no "halloing" between keeper and marker. A code of signals may be arranged, a whistle being used for preference. It is well, however, for the keeper or one of his underlings to interview the marker from time to time and thus be able to obtain accurate information.

(3) It should never be suggested that guns should go into a turnip field unless birds have been seen to go, or are known to have gone, into it.

(4) Before the guns and beaters begin to cross a field, the keeper should see that the hedgerows at the beginning of the beat are thoroughly searched, and that all the fences are explored, before the field is finally abandoned.

(5) The keeper should be particularly careful to warn the guns to keep a sharp look-out at the end of every beat. Guns are apt to slacken their attention as they approach a hedgerow or the corner of a field. It is at such places that birds, which have run ahead in front of the guns, are apt to rise.

(6) If it be left to the keeper to decide how the guns 
and the beaters are to advance, he may choose one of several methods, the most usual being the advance in line and the "half-moon" principle. The former plan is the more common, especially when the field is at all extensive, but it is as well to recommend, when this practice is followed, that when the end guns are close to a hedge one or two of them should be flanked, that is, a little in advance of the others. When a strong wind is blowing across the field, it would be better that the line be flanked in every beat. The keeper's attention must be constantly kept to the formation and evenness of the line of guns and beaters. If the "halfmoon" pattern be used, it is necessary to drop a polite hint as to the danger involved. If this be done judiciously, it will be well for the whole party and will not cause offence.

For an elaborate description of this form of advance, and for information as to other less used methods such as the advance by echelon, the keeper is referred to Lord Walsingham's excellent account in the volume on Shooting in the Badminton Library.

It is hardly necessary to add that in approaching a covey in a stubble or lea field, never by any chance should the guns be advised to advance directly on the birds. They must be flanked, and approached by a wide horseshoe pattern, which tends to become a circle as the guns proceed.

(7) If in beating a field there be no desire to drive birds in one particular direction, then the guns and 
beaters should wheel; but if it be desired to force the birds ahead, the line should come back to the original starting-point.

(8) When a single bird is killed, the place should be carefully marked by the keeper or by one of the beaters, and the line should continue to advance till the place is reached. Where several birds have fallen, sticks should be planted at the nearest points possible to the places where they are likely to be found. When a bird towers or falls at a great distance, an attempt should be made to mark the spot by selecting some object in the field of vision that will give the line of the bird-a tree at the end of the field, some outstanding piece of growth in the field, or a gap in a hedge, may be useful for this purpose.

(9) In working the retrievers for picking up birds, the following instructions should be carefully remembered :- (a) First pick up the birds that have fallen behind the guns. (b) Leave alone all consideration of runners till the dead are picked up. (c) Never allow a dog to go on to fresh ground. Runners or birds that have dropped far out may be picked up in later beats, care being taken to remember their line. If, in the later beats, there be any difficulty in finding, a man may be left behind with a retriever, while the guns proceed to another cover. (d) Only send a dog immediately forward to a killed bird if you can absolutely trust him. (e) In picking up a bird, let the dog have the wind of it. Dogs work better alone, and not with men 
near them to spoil their scent. Men carrying hares or rabbits are especially to be warned off.

(Io) The keeper should remember the unvarying law-the line must move slowly, evenly, and silently.

Note.-It is in every way to be recommended that, where partridges are habitually killed by the walkingup principle, an occasional drive should be arranged. In this way the coveys are dispersed, there is an interchange of blood, and old barren birds are killed off.

\section{Driving Partridges}

There are several important points in connection with a partridge drive that the keeper should keep in his mind :-

(I) The question of fences is of importance where partridge-driving is regularly practised year by year. The keeper should, along with his master, try to use persuasion with the farmers not to cut their fences too low. If the good relationships referred to in Chapter III. be maintained, this should be easy. Shooting from behind a good high hedge is quite a different matter than from behind a low-clipped one, or from behind an artificial "butt" in the shape of an improvised hurdle.

(2) In the majority of cases the keeper will find that the guns will take up their position for shooting guided by their own knowledge of the sport, but he may be called upon to indicate to the less experienced the best positions to assume. He will keep in mind 
the necessity for good cover, and remember the rule of experience, that guns should stand near to the hedge in up-wind drives, and well out from the hedge in down-wind drives. From a high fence in the latter case the guns should stand far out.

(3) The law of making experimental drives, as laid down in the chapter on Grouse, must be followed. In this way the line of the general flight of the birds will be learnt, and it must be carefully remembered that partridges will not be driven the way they are not accustomed to go.

(4) It is best to preface a drive by ordering the beaters, in the morning, to drive the birds from off any outlying ground.

(5) It is advisable to have the first drive with the birds driven down wind.

(6) The beaters, on moving forward to a drive, should pass along a boundary fence.

(7) In bringing back the birds for another drive, the knowledge of their flight is important. It is useless to attempt to bring back birds from directly behind the guns if the birds have not flown there. This seems a truism, but it is necessary to indicate that such foolishness is often practised. Remember the seemingly simple, but oft forgotten, rule: Bring back the birds from where they have flown with the wind.

It is advisable, in bringing back birds against the wind, that some of the guns should walk with the beaters, as a great many birds in this case break back. 
(8) The head-keeper should form the centre of the line of beaters, to guide and warn the flanks, and he should, for preference, be mounted.

(9) The law of flanking is the same as in the case of grouse-driving. A screen, well thrown forward, should always be formed on the down-wind side. Flanks should be enlarged and increased according to the wind, and it is as well that good guns be placed along with the flanks who are on the down-wind side. When there are no guns on the flanked side, or when their presence is discounted, there should be a good deal of shouting and waving of flags on that side.

(10) In addition to the keepers, who stand with their retrievers behind the stationary guns, there should be a keeper or two at the other end of the field in which the guns are standing, to mark and pick up towering birds, and those that have dropped far out.

(I I) All birds should be picked up on the day of the drive. Scouring the fields on the day following disturbs the birds too much. Partridges should always be allowed a day of rest after a drive.

\section{Poaching the Partridge}

Where it is possible, there should always be extra hands engaged in the nesting season, and every care should be taken to systematically watch the fields where there are nests. Bushing must be carefully carried out. "An excellent plan" (writes Sir R. Payne Gallwey) " to check the operation of poachers 
who net partridges, is to procure three sticks of thorn, each $2 \mathrm{ft}$. long, tie them across in the centre, with wire or tarred string in the form of a cross or star, sharpen their ends, and place one of the points lightly in the ground. This arrangement cannot be seen at night, and on being touched by a net rolls up in it end over end like a wheel. The sticks can be kept from year to year ready for use, and be quickly placed in position in the fields."

Another plan is to drive oak posts, about an inch square and 2 to $3 \mathrm{ft}$. long, into the ground at various points over the fields. It will add to their usefulness if a few nails be driven into the posts near to the top.

But whether bushing, poling, or other method be carried out, such practice must not supersede careful day and night watching. 


\section{NOTES}




\section{CHAPTER XI \\ The Deerstalker}

\section{By Captain Henry Shaw Kennedy}

To my mind, for an outdoor servant, there is no more delightful occupation than that of a deerstalker. His life is generally spent in wild and magnificent scenery, and though the house or lodge he lives in may be isolated-perhaps twenty miles from the nearest town or village-yet there is a charm in the isolation, and there is a slight romance in living out of the world far from human ken. What can be more delightful than to feel that the "wild red deers," as they call them, are your only neighbours for miles and miles. Well, if these are not to the stalker's liking, I should advise his taking to some other trade.

But now to business. Every man is not fitted to be a deerstalker - in fact, very few men are. No man need attempt to take on this job with success unless he is sound in heart, lung, and limb, with sight of the very best. The stalker must be a first-class walker-never know what it is to be tired; and, above all things, his soul must be in his work.

It is no easy task to outwit a large herd of deer, over 
ground they have lived on for years, with tricky winds blowing up the corries, and take your "gentleman" safely up to shooting distance.

My experience of the deerstalkers I have met and crawled with, and they are a goodly few, I look back upon with the greatest pleasure. I have invariably found them most delightful companions and keen (in fact, sometimes too keen) sportsmen, and I may say that some of the happiest days of my life have been spent on the hillside in their company, and I don't think I am wrong in calling them Nature's gentlemen.

Now and again one comes across lazyand indifferent stalkers (men who, in many cases, have become degenerate by the too frequent use of the black bottle), but, as a rule, they are few and far between, and for them I have no use, and have nothing to say.

These few little hints I am now writingare not meant in the least to serve as advice to the old deerstalkerhe has little to learn, and is as wise and cute as the red deer himself or an old cock grouse on a mountainside; but it is for the young stalker learning the practices of his trade that I write these few lines of simple advice, which may possibly be of use to him. For, looking back on old stalking days, how well I remember many a long and difficult stalk and crawl magnificently planned and carried out by the stalkers, marred at the last moment by some trifling error arising from want of experience. Instead of the stalk being a red-letter day in the forest, a day crowned by the prize of a goodly stag, it has ended 
merely in a long, dreary walk home in the dark, with your "gentleman" low and depressed in spirits, and fully aware that he will be well chaffed over the miss when he returns to the lodge.

We will now imagine ourselves in front of a forest lodge, time 9 a.m. (I am all for stalkers being " early astir," as the sporting papers term it, for late autumn days are short). Stalkers, gillies, and ponies with deer saddles, the number of the latter varying with the number of rifles to take the hill, all are preparing for the start.

Now, young stalker, the first thing, we presume, is that you are suitably dressed. Nothing to my mind can be better than Lovat mixture, but there are one hundred and one different patterns of cloth equally as good, and in several forests they have their own particular brand that they swear by, which is worn by stalkers, gillies, and the "gentlemen" themselves. However, these are matters of detail. Of course, the nature of the ground makes some mixtures much more suitable than others.

Of one thing I am certain : it is always best to have the whole of your suit and your cap made of the same material. I have often watched a line of grouse drivers on a hillside through a glass from a distance, and have always found the most conspicuous were those who wore mixed suits-that is, coat of one material and knickers of another.

As regards boots or shoes, I prefer the former, as they give more support to the ankles; and spats when 
wet are apt to make cold feet; but this is entirely a matter of taste.

As each "gentleman" is told off to his beat by his host, this is the time, stalker, young or old, to be observant. Make certain you have got your "gentleman's" rifle and cartridges. I have known the discovery made when nearing the end of a stalk that "the bullets" had been left behind. If you are to take the hill with a sportsman you have been out with before, you have little to learn; but if he is a newcomer, you must try and find out for yourself, unobserved, what he is made of before getting him up to deer. In all probability you will have a mile or two to walk up the valley or up the hill before you come to the first spying-ground. As a rule, your "gentleman" will walk with and talk to you, and now is your chance; he may be an old shikari and know every card of the game, and be able to walk as well as, perhaps better than, yourself, and may be able to teach you a wrinkle or two; but this you will not be long in finding out, and vice versa.

Should your "gentleman" be elderly, or you find that he is not a good walker, you must at once suit your step to his pace as much as possible, for many a good day has been marred and many a good stag missed by young stalkers not keeping this fact particularly in mind. They bring their "gentleman" up to shooting distance faultlessly, having made a magnificent stalk in treacherous wind over most difficult ground. But too fast! too fast! they have never turned to look 
at the panting object behind them; the rifle is pulled out of its cover, shoved into the sportsman's hand, and the whisper, "Tak' 'im noo, tak' 'im noo, Captain-the big black one." But alas! the sportsman's sides are heaving, his heart is throbbing, and his hand is shaking from excitement and fatigue, and, getting up, he draws an unsteady bead, which results in a miss and remorse for the rest of the day.

Now all this might have been different had you adapted your pace to that of your "gentleman," which, if deer are settled, it is just as easy to do as going at your own pace. Of course there are times, when deer are on the move, that you must go fast-in fact, racefor a shot, but the stalker should always remember that there is not the slightest advantage in his being one hundred or two hundred yards in front of his "gentleman" (a condition of affairs I have seen). The two should be in close touch with one another.

But let us now hark back to the spying-point. Now, young stalker, we will presume that you are thoroughly acquainted with a glass, and before you have sat down two minutes to spy you will know if your "gentleman" is at home with it or not. He may be a first-class man with the glass, but you must not think you are a better man than he because you pick out deer first, as this results from the fact that you know the ground and exactly where to find them. The sportsman, on the other hand, is heavily handicapped, being a stranger and not knowing the likely spots to put his glass on ; 
but in two minutes, as I said before, you can tell if he is at home and of any use with the glass. The novice you will detect at once; he is quite at sea with it, and has not the slightest idea of putting himself into a spying position, nor of keeping theglass steady-one minute he gazes at the sky, the next he plunges into the heather. Now, having discovered your "gentleman" is a duffer (you need not tell him so), but seems anxious to learn, do everything you can to show him the best spying positions-off your knee, or off a stick, etc., and above all things be patient-suit yourself to the occasion. Of course, it is a thousand times better and far less trouble for you to find your "gentleman" an accomplished stalker. You may then very often pick up little hints from him if you are attentive and observant, and you can both work so much better together and consult one another as to the stalk.

But let us suppose you have found deer from your first spying-point, and a stag among them fit to shoot, and your "gentleman" a novice, then take plenty of time to explain matters to him, make him have a good look at the deer through his glass, point out to him the way the wind is blowing, and how you intend making the stalk. This procedure will be far more interesting to him than if you shut upyourglass, telling him nothing, as some do, but simply let him follow you like a shadow as you crawl and creep over rocks and wade through burns. It is far more exciting for him to know the spot you are making for than to treat him as a nonentity. 
Therefore explain to him that when you are crawling he must crawl, and when you are slithering he must slither, and when you lie flat he must lie flat, and should you suddenly stop (an action prompted perhaps by an old hind looking up), he must stop at once also, in however disagreeable a position he may be, and not move a muscle till he gets the "office" from you. Sometimes you are caught with one knee in a green spring and the other on a sharp rock, which is anything but pleasant ; but such are the ups and downs of deerstalking. When you are crawling with an inexperienced "gentleman," it is always best to look round every now and then to see if he is acting in conformity with you or not, for sometimes a stalker cannot conceive what has put deer off the ground till he looks round to find his "gentleman's" head buried in the ground, but his heels in the air, or some part of his body showing.

Now, having walked, run, crawled, wriggled, slithered over fearful ground, sometimes in sight of deer and sometimes not, you have arrived safely within a few yards of where you expect to get your shot-now is the time for you, of all others, to keep perfectly calm. Nervousness and excitement are very infectious, and you are very apt to infect your "gentleman," especially if he be a novice, and very often if he is not. I cannot imagine any more exciting moments than those spent as you are just crawling up to the last little hillock or rock, knowing there is one of the finest harts of the forest within one hundred yards. 
Have the cover of your rifle unbuckled and all ready to be pulled out in a second; see that it is loaded and the safety bolt properly adjusted and in working order; it is never desirable to crawl with a loaded rifle more than is necessary; and, above all things, do not take for yourself the best, and perhaps the only good spot to shoot. Make your "gentleman" creep alongside of you, or even a few inches in advance; let him have the front seat now, and choose the position he likes best to shoot from. I have often seen a good, experienced stalker take the front and only possible place to fire from himself, pull the rifle out of the cover, thrust it into his "gentleman's" hand, and expect him to shoot as best he could.

There are a hundred and one little trivial circumstances that cause $a$ miss at the last moment that could be so easily avoided.

Crawl close up alongside your "gentleman"--do not let him fire till the stag is offering a good broadside chance. If the deer have not "taken you up," there is no hurry whatever, unless the light is failing, when the sooner you shoot the better. Now, having given your "gentleman" the hint- "Tak' him noo, Captain," he will at once place his forefinger round the trigger in the shape of an "'ook" (as our old drill sergeant used to teach us), " and, without moving the "'ead, 'and, or heye,' press the trigger gently until the 'ammer falls"; and I think, if he follows out these instructions to theletter, the stag will also fall-and thus conclude a successful stalk. But other little trifles very often cause a miss, such 
as blades of waving grass or heather being in front of the foresight. Now, to avoid these, the rifle must be raised to clear them, with the result that it is then found difficult to secure a good rest. To overcome this difficulty, if the ground is suitable, lie face downwards in front of your "gentleman," and give him your shoulders as an excellent rest to shoot from. It will, of course, be necessary to gradually raise or lower yourself until he gets the right height. A short stick is also very handy to shoot from if used carefully, but, of course, you run the risk of its being " taken up" by the deer. Another point I would advise all stalkers to be most careful of, and that is, having got their "gentleman" safely up to the last shooting-point, be sure that he takes the right stag. I have often seen terrible disappointment by his taking the wrong one. Nor is it always the sportsman's fault. Perhaps for over an hour he has been crawling behind the stalker, his nose glued to the latter's boots, and has never had a chance of looking at the deer he is stalking, till the last hurried moment before firing ; and it is not always so easy to pick out the best stag amongst a big lot, wildly scattered, unless there is something very distinctive about his head or body. Now, the "gentleman" having taken his shot, and you have seen that the stag has got it in the right place and is lying dead on the hillside, it is best to remain still for a minute or so, as the herd of deer are much more likely to settle again soon, and not go over the march, than if you rushed in before they are out of sight. 
It is safest to unload the rifle after the stalk is over.

Having "galloched" your stag, put him on the pony, and started him for the lodge, and have your lunch, and the day being still young, you can commence again, spying freshcorriesand findingfresh deer, and may, perhaps, have one or two more successful stalks before night ; but on no account should you be bloodthirsty-it is much better, to my mind, to have a blank day than to bring in an unshootable stag; it spoils the average weight of the year, and, if many of these sort are shot, it spoils the reputation of a forest. A stalker should know exactly his master's wishes as to how many stags one individual "rifle" should bring in on one day. I have known a "rifle" go out and, being carried away by his own excitement and his stalker's encouragement, bring in five, or even six, stags in a day, which were not worthy to hang by their heels in the larder.

Now, to my mind, that " gentleman " need not think himself hardly used if he is not asked to shoot in that forest again, and the stalker need not think himself a martyr if he gets the "Royal Order of the Boot." These "Waterloo" days, when several indifferent stags are killed, spoil the sport for others, as later in the season, when real good stags come on the ground, they cannot be shot, as the limit may have been reached which, to put it mildly, is a most annoying fact.

Now I am going to tread on very dangerous ground. A stalker cannot be too careful how he acts with regard to the forests that march with him. I don't think I am 
exaggerating when I say that, as a rule, there is more jealousy, more rivalry, and more cool feelings (may I use the words?) among neighbours on deer forests than in any other locality. I find it exists not only among the owners, but among the stalkers and the gillies, and this jealousy is as infectious as the grouse disease itself. Again, Mr. Stalker, I offer my humble advice. If it be possible, do all in your power to keep friendly with your neighbouring forests and foresters. I am sure it will pay you best in the long-run, for, in many ways and particularly in adverse winds, your neighbour can do incalculable damage to your sport.

Now we will jump from the neighbouring forests to your glass-not the glass of Glenlivet, but to your telescope-to my mind by far the greatest friend a deerstalker has got, for, when it fails, you may as well "put up the shutters." It is the one great pull you have over the deer, as you are able to pick them up long before they, even with their keen eyes, can detect you. Now, you cannot be too careful of this said glass. In very bad weather it is very apt to get fogged and be quite useless until taken to pieces and dried. Remember, then, when your glass is "bunged up," you are badly handicapped, and, to my mind, you lose half the pleasure of stalking. If it is a very wet day, use your glass as little as possible. A good plan for you and your "gentleman" is to take it in turns to spy, so that, if one glass gets out of order, you have the other to fall back upon. Always take your glasses to pieces every night and have 
them well dried in front of the fire. This rule applies also to the case, which, if damp, is apt to fog the glass. A waterproof cover to slip on when the glass is in use will be found a great protection.

I will not go into all the " pros and cons" of different rifles-you could write volumes on this subject, and every man knows what rifle he prefers. The great thing, to my mind, is to hold them straight. I have often heard the very best of rifles abused for inaccurate shooting, when the real cause was "stag fever"-a very common complaint. As a stalker, you will most likely be provided with a rifle of some sort to shoot hinds with in the winter, and, with a little practice, you can soon suit yourself to any rifle. Remember always that, like your glass, you cannot be too careful with your rifle or that of your "gentleman." They should be cleaned immediately after you return from stalking, and hung up. Some sportsmen of my acquaintance clean their rifles themselves, and do not trust any one else to touch them. Of course this is the safest plan, and no blame can be attached to the stalker if anything goes wrong. I should advise having a rifle sighted-not too finelyto shoot point-blank at a known distance, say ıoo yards, and then you can work up or down, i.e. now higher or lower for longer or shorter distances, which will as a rule vary from 80 to 200 yards.

Try to avoid getting too near your deer, and do not encourage the novice to try long shots.

The stalking season over, the sportsmen having all 
gone south, you are left a good deal to your own devices. You have the long winter to get through, which, of course, must be more or less monotonous in your isolated lodge, but if you are a good man, you will find plenty to keep you occupied-watching your deer in the heavy snowdrifts, and doing what you can for them. You will also very often have hinds ${ }^{1}$ to kill, and, next to stalking the stag himself, what better sport could you wish for? Then, when the New Year comes round, you can spend many an hour watching for good stags to shed their horns, for these, and many other little items, such as skins, etc., are looked upon as the stalker's perquisites. $^{2}$

\section{On the Deterioration of Heads}

Before concluding, I would like to make a few remarks on a subject that hardly comes under the heading of "The Duties of a Stalker," but yet must be a most

1 This question of hind-shooting is of primary importance in its applicability to the improvement of stock. We leave out of count altogether the question of good venison, which ought to be secondary to the desire to assist the general welfare of the forest. In keeping this in view, the main point to be attended to is the destruction of old hinds, whose calves are in ninety per cent. of cases feeble and unhealthy, and, in the opinion of many authorities, chiefly females. The stalking gillie is too apt to lose sight of the primary object of his work, and to select wellconditioned hinds, instead of the decrepit females before mentioned. "It has been proved," says one writer, "that ninety per cent. of yeld hinds killed would have had stag calves in the ensuing season. Thus, every ten yeld hinds killed mean a loss of nine prospective stags to the forest." On this account yeld hinds should be left alone.

P. J. M.

${ }^{2}$ Every young stalker should procure, if possible, a small copy of Mr. Grimble's excellent book on Deerstalking. In it he will find a fund of information. 
interesting and useful study for him, and that is the growth and development of the deer's horn, from the time it commences to sprout (covered with velvet) from the stag's skull, till later it develops into what I consider one of the most picturesque and most prized and valued trophies a good sportsman can possess, a finely matured stag's head. I feel I am treading on dangerous ground when I write on this subject, so many abler and more experienced men than myself have made a lifelong study of deer's horns, and a great many most interesting and instructive articles have been written regarding them, and yet, in spite of all this writing, and in spite of all this study of animal life, there is no disputing the fact that of late years the heads of Scottish red deer have been deteriorating greatly, and "all the king's stalkers and all the king's men" cannot put a stop to this and make them pick up again. I think I am correct in saying that this deterioration is going on in almost every forest in Scotland, and I think all old stalkers will corroborate me in this and tell you the same tale,_- "Heads are going back, back, back!" What is to be done? Money will not stop it, artificial feeding in winter will not stop it, and the introduction of fresh blood and park deer seems of no avail, though I do think that good wintering in a small way helps deer to grow better heads. But in my very humble opinion, and I trust I will not bring a hornet's nest of deerstalkers about me for what I am going to sayto my mind, the key to this deterioration of late lies in 
the wholesale killing year after year of the very stags that should be left to reach maturity, and produce good stock. But how is this to be prevented? It is next door to impossible. The majority of forests are let to yearly tenants who pay very large prices for them, and very naturally wish to make the most they can out of them, which, of course, means killing off the finest heads in the said forests. As this continues year after year, a good forest goes from bad to worse, till at last it becomes a wilderness of wretched, miserable stags, with heads that no good sportsman would care to hang on his walls.

Now, to be brief, the best possible cure for this deterioration is, of course, to spare as much as possible all six, seven, or eight-year-old stags with promising, well-shaped heads, and so give them a chance, when they are ten or twelve years old, of carrying magnificent heads such as one sees in old drawings of Landseer and Crealocke.

There is one great drawback to this attempted preservation of young stags with promising heads, and that is, that although you do everything in your power and skill to save them, your neighbours may kill anything or everything that comes within reach of their rifles, and so ruin most of the good you are trying to effect.

Now, Mr. Stalker, it is very often in your power (though not always) to prevent the class of stag of which I have been writing from being shot, and when 16 
you save one of these you contribute your mite to the improvement of Scottish red deer's heads.

\section{Deerstalking Notes.}

In addition to what has been said in the body of this chapter, the following points should be observed by the young stalker :-

(a) Never attempt a down-wind stalk.

(b) Always try to stalk down hill, as deer seldom look up the hill, and always try to have the sun at your back and shining in the eyes of the deer.

(c) Remember the general rule, that deer move up wind when they are feeding.

(d) In fine weather the biggest stags are on the highest hills; in wet and stormy weather they are on lower ground.

(e) Do not stalk, or be very careful, on days when there is a very high wind, as the deer are apt to dash about from place to place without any obvious reason.

(f) Remember that whatever wind may be blowing across the hills, there is always a current moving $u p$ and down the narrow glens. It is therefore wise to carefully spy out the ground near to where the deer are grazing, and notice the movements of the grass in their vicinity, and make your stalk accordingly.

Mist is the bugbear of the stalker, but in times of enforced inaction is not wasted if you watch carefully and note the drift of the mist as showing the different currents of air, many of them very contrary to the 
general direction of the wind. Constant observation is the making of a good stalker. Never try to stalk in thick mist. You will do much harm and no good.

$(g)$ The distance one may approach near to a herd varies. When there is a strong wind it is not safe to pass within a mile of the herd.

(h) In making a stalk, be particularly careful to avoid any outlying herds of deer; if these see you they may scamper over the forest and upset all your calculations.

"The best laid schemes o' mice and men

Gang aft a-gley." 
NOTES 


\section{CHAPTER XII}

\section{The Rabbit}

Generally speaking, rabbits are a nuisance on a property, and should be kept down to the lowest limits. They are a constant source of annoyance to the farmer, and a source of expense to the proprietor who plants. They do great damage to young trees, and unless the keepers are very energetic in trapping them, a few rabbits in hard weather will soon spoil a plantation. The only sure method is netting, but this is an expensive means of limitation, so that it is questionable whether bunny is worth his meat. Some farmers are curiously inconsistent; for instance, it has just come within our notice that on an arable farm, where orders had been given to kill down all the rabbits, the grumbling farmer complained that they were being killed down too hard, and that he could not get as much as a rabbit for his house. Farmers were not content till the law was altered to give them compensation for damage by game, and now that they have got the rabbit kept down, they complain against its loss. Another strong objection urged against the rabbit is that it draws poachers. 
The gamekeeper is called upon to regard the rabbit in a variety of aspects, and these may be thus categorically enumerated-(I) As vermin ; (2) as a comparatively unprotected and unpreserved occupant of a shooting estate; and (3) as a member of a carefully preserved and systematically protected warren; and in dealing with him in the latter capacity the keeper has to view him either as part of a farm-that is, when the rabbit is preserved mainly for market purposesor as part of a sporting property-that is, when he is preserved for the purposes of shooting.

He will most likely be called upon to view the rabbit as vermin in the following cases :- ( I) On a good moor, generally; (2) proximate to good partridge cover ; (3) and near to special cultivated ground-as, for instance, farms, gardens, lawns, and the like.

Many owners have no objection to a stock of rabbits existing on their moors, but in every way they are to be regarded as a pest, especially in those cases where shooting is practised over dogs, or by simply walking up the birds. Many a brace of birds has been missed owing to the fact that the barrels of the shooter have been loosed on a rabbit. On this account it is as well that the rabbit should be exterminated on a moor, and not only on this account, but also in view of the voracious habits of the beast, and more particularly on account of the fouling of the ground by its excretions. There are cases, however, on small and badly stocked properties, where the chance of an occasional rabbit 
affords some consolation to the weary shooter, who, after tramping for hours without a shot, regards the furtive bunny almost in the light of "game." The presence of rabbits at least ensures his return with something in the bag.

(I) To the keen and experienced rabbit shot, nothing affords better sport than rabbits in heather, but where such is desired it is better that a certain part of the moorland be reserved for the rabbit stock. On most shootings there is a considerable acreage of ground near to the lodge where rabbits are plentiful enough for such purposes, and where birds do not generally breed. But these facts do not upset the general rule that on a moor the rabbit is to be regarded primarily as vermin. (2) In regard to good partridge cover the same remark is to be made, although in this case the main objection to its existence is in relation to the feeding capacity of the ground. As a rule, there is not so great an objection to its presence as in the case of the moor, especially when the cover is extensive and is used as shooting ground. A day among the "whins" would lose half its attractions were it not for the rabbits which afford such excellent practice as they dart between the bushes, and the escape of a covey of partridges means merely, as a rule, a flight into turnips or potatoes, the best and natural cover in which to kill them. But if the cover just referred to is required for a good stock of partridges, and if its food possibilities are limited, and especially if the birds are not to be 
disturbed till the first drive, it is better to get rid of the rabbits. (3) The destructiveness of rabbits is notorious, and the keeper will often be called upon by his master to protect his garden and his flower-bedded lawn from their encroachments; and a farmer has a right to protest in those cases where rabbits are laid down to such an extent that they overrun and materially damage his crops.

So much for the rabbit as vermin. In considering him as a comparatively unprotected and unpreserved occupant of a shooting estate, we are regarding him in his most popular and most general aspect. We use the word "comparatively" advisedly, for in nearly every case some protection is necessary both for the sake of the rabbit and for the sake of proper shooting, and however little attempt is made to convert a small rabbit shoot into the proportions of a warren, yet it is necessary, if rabbits are to be all healthy or numerous, that the rule as to the addition of newblood be observed as carefully as in the case of the latter. The unvarying rule is, that new blood should be introduced every year. This is a rule, however, that is almost invariably neglected. The law of intermarriage is the same throughout the whole animal world. Intermarriage amongst peoples tends to the deterioration of the race. An uncrossed grouse stock tends to disease and death. A rabbit stock which is left to itself accumulates diseases of the most virulent description. The danger is far greater in the case of rabbits than in that of birds, 
owing to the migratory habits of the latter. Many people refuse to eat rabbits owing to a suspicion that disease is likely to be present. This may be an extreme and an unnecessary caution, but the mere fact that it exists indicates the truth that such disease is $a p t$ to be present.

It is difficult to lay down a general law as to the number of rabbits to be put down each year, when we are not dealing with a warren, but merely with scattered rabbit burrows, but we should say that about three or four to every hundred acres of ground would be sufficient. The best time is when the shooting is over, but not later than the middle of January. This is late enough to permit of the Christmas shootings. When there is sufficient evidence to prove that the rabbit stock is diminishing from any cause apart from the destruction by gun and trap, the whole stock should be obliterated and an entirely new one laid down. Great care should be taken in the selection of the ground from which the new blood is taken. It should come from districts at as great a distance away as is consistent with convenience, and should be from ground where the laying down of new blood is consistently and habitually practised, and, if possible, from ground where rabbits are not too numerous. In selecting the rabbits, bucks should preponderate. In the majority of cases it is easy enough to arrange an interchange of blood. For this, it is of course necessary that the health of one's own stock should be above suspicion. 
The unenclosed burrows with which we are now dealing are, in the main, used for the purposes of ferreting, and it will be the duty of the keeper to see that there are convenient arrangements made for the purposes of the guns. It is often necessary to do a little clearing in the vicinity of rabbit-burrows, especially when there is much undergrowth. When the burrows are in thick wooded cover, rides may be made - not only the wide-open rides as used in pheasant coverts, but smaller ones not open to the sky. Rides should also be made on bracken ground and on the heather land that is used for rabbit-shooting. In the latter case the rides are most useful, for where the heather is thick, old, and long, there is little or no chance for the gun to spot his rabbit, until perhaps he sees it disappearing over the edge of a knoll, or into a hole, a hundred yards away. If the heather has been well attended to, and this is very exceptional on land that is near to the lodge and is used primarily as rabbit-ground, the rides are not so absolutely necessary, and sporting shots might prefer to take their chances without their aid.

It is often desired to lay down stock on ground that is at present untenanted by rabbits. When this is done outside a warren and chiefly for the purposes of ferreting, suitable ground will of course be chosen; -that is to say, ground which combines the necessities of food and good opportunities for shooting. This ground should be temporarily closed in by wire fencing, 
and should be scooped out here and there to assist the rabbit in the process of burrowing. After the ground has been sufficiently burrowed the fencing may be removed.

\section{The Warren}

A warren may be an extensive stretch of ground a quarter of a mile or more in length, or may simply be a three-acred field. In the former case, no change of venue is necessary; in the latter, it is usual to change it from time to time, say once every five or six years. The ideal warren must be well drained, well supplied with food, and well enclosed. The soil should be sandy and porous and free from the possibilities of flooding. Good natural warrens stretch along the banks of rivers, but have a considerable elevation above high-water mark, and slope gently upwards towards the pheasant covert, which stretches in almost parallel lines with the windings of the river, and are enclosed at each end, either by natural fences, protected by wire-netting, or simply by this netting erected on wooden palings. A good warren of this type has varieties of cover, bracken, broom and gorse, heather and hussocks of grass, and here and there small juniper trees, and varieties of shrubbery. But although such a warren is described as a natural one, it is liable to the same laws as the ones we may term "artificial." The extinction of vermin must be thoroughly looked 
to, the cover must be regularly supervised, wiring must be carefully examined, draining carried out, and, if necessary, lime occasionally scattered to counteract the fouling of the ground, overcrowding avoided, and evidences of disease carefully noted.

Where no such natural warren exists, and it is proposed to construct one, it would be to the advantage of a keeper if he visited some well-known warren, and took into view the natural conditions which he proposes to imitate. In selecting his ground, he should keep in view the following points:-(r) The lie of the land; (2) the condition of the soil; and (3) the capacity for cover. The land chosen should in no case be on clay soil or be rocky ground. Sandy soil is the best, although peaty ground is not to be sneered at. The place chosen should be fairly high, and of an undulating nature. Great trouble will be saved if ground can be found which has been already well burrowed, so that the new stock laid down may soon find a home. Where these burrows do not exist, the keeper and his underlings must assist nature by some preliminary digging, as we have described before. Where nothing but a clay soil can be obtained, artificial mounds may be constructed of a looser and more porous earth, sown with grain seeds, and containing holes which can be readily converted into burrows. An excellent form of warren can be made by simply enclosing a piece of moorland southern exposure where the heather is not too rank, and which already contains rabbit 
burrows, and a certain amount of isolated trees and shrubbery. This land, if well cut with rides, is both excellent feeding and shooting-ground. It is important that the burrows be distributed pretty evenly and generally in the warren. Where it is found that rabbits have collected in one area to the exclusion of others, and there is a danger of an insufficient food supply, it might be as well to construct temporary enclosures within the warren, in which the rabbits may be placed, and these enclosures kept up till such a time as burrowing is complete. Great care is necessary in regard to the cover available. It may be necessary to scatter fern or gorse seed, or even to plant or transplant trees and bushes. Most good warrens have, here and there, large flat heaps of the branches of trees. These afford excellent cover, and are especially to be recommended when the warren is used for shooting purposes. Where the warren is a permanent one, or where there is a suspicion that temporary ground has become stale and tainted, some addition to the natural food must be made. That great authority, Mr. Lloyd Price, recommends that portions of the ground should be fenced with wirenetting, and crops of clover, oats, or beans grown within the enclosures. When these have been carried, or partly so, the wire-netting may be removed and the rabbits allowed access to this reserved ground. By changing the position of these plots, the rabbits get access periodically to fresh, untainted ground, and thrive accordingly. During the winter it is always 
wise to give the rabbits artificial food by scattering corn and good hay here and there over the warren. Some authorities recommend swedes, but these are better avoided, for, although they agree with some rabbits when they are associated with corn and hay, they are apt to produce intestinal and other troubles.

It may be as well to quote a more elaborate, yet simple enough, method mentioned by Mr. Lloyd Price, for constructing a warren (Encyclopcedia of Sport): "Find a field or rough open space, either partially or wholly surrounded by woods, in which rabbits live and breed. Let this be walled round, and let holes be made in the wall at regular intervals, and closed by wooden or iron shutters at will. Encourage the rabbits to feed in your walled-in ground. Of course the beasts soon get quite at home in your enclosure. A night or two before you shoot, shut down the shutters and the thing is done. An improvement would be to make the shutters of light iron bars, to swing outwards from the cover into the preserve shambles, or whatever we choose to designate the field of slaughter; the rabbits would soon learn to use these, and as the gratings would swing back of themselves, preventing the return of the tenants, your enclosure would soon fill itself without any particular attention on the part of the keeper. Care must be taken, however, not to leave the huge trap too long without emptying, or else to supply plenty of food inside, or the rabbits would starve." It is perhaps as well to impress 
upon the keeper that great care must be taken with the fencing. This must be thoroughly carried out at the beginning, and examined carefully afterwards, in case any destruction may have been made by sheep or other animal pasturing in ground approximate to the warren. A single or a double strand of barbed wire outside of the warren fence is useful to prevent such inroads. Wirenetting must, of course, be turned over both top and bottom, for rabbits are good climbers. It might be as well that a single barbed wire be stretched across the curve at the top. The points at which the wire-netting is turned over must be strengthened by fairly thick wire, to prevent bending.

In summarising the facts to be remembered by the keeper for the prosperity of his warren, we might tabulate the following, which must receive his earnest attention :-

(I) The proper food-supply of the warren. Where cut hay is supplied, care must be taken that it is kept dry and healthy by some form of covering.

(2) Thecareful and habitual restocking of the ground. This must be done annually, with healthy rabbits from other warrens, as rabbits breed rapidly. Kill down stock in winter hard, especially the ones that lay out, these being generally the weak ones expelled from the burrow by the stronger does and bucks, who keep possession of the stronghold, these being 
useful for breeding healthy big stock. As rabbits are subject to interbreeding and remaining about the same burrow, ferreting is useful in order to change the habitat and encourage interchange of blood.

(3) Proper fencing.

(4) The elimination of vermin.

(5) Draining, if necessary.

(6) The occasional scattering of lime and salt to prevent fouling.

(7) Avoidance of overstocking. In a case where a warren is used for profit, about one hundred rabbits to the acre is a good average, but only about ten to the acre where it is used for shooting purposes.

Where a warren is small, great pains must be taken with the care of the ground. If the venue of the warren be not changed, careful liming and artificial feeding must be had recourse to. It may be even dressed with some phosphatic and lime mixture, of which, perhaps, dissolved bones is the best. But it is strongly to be recommended in the case of small warrens, that the venue should be changed every five or six years, so as to secure new feeding-ground and to give the old ground a chance of recovering its food capacity and its healthy condition.

\section{Shooting the Warren}

The main point to be observed in this connection 
is to assert, once and for all, that on no account must ferreting be used for making the rabbits lie out. Gastar is the only thing to use. Let every hole be blocked about five days before the shoot, and let the thrown-up earth be sprinkled with the tar. Next day go round the holes again, and block as before. Do this every day till the time of the shoot, and the process is complete. Your whole stock is in the warren, eating in the open, or lying among the bracken or round the foot of trees, or under the heaps of faggots. Let this method be tested once, and such processes as ferreting, smoking, and the like will pass into the limbo of archaic ignorance.

With regard to a warren shoot, it is only necessary to remind the beaters that they must prod, and not beat out the rabbits. Every foot of the ground must be carefully probed, faggots must be thoroughly overturned and explored, dogs must be kept well leashed and brought up to the line. There must be no stragglers. The whole party of guns and beaters should move across the warren like a battalion of infantry advancing in line. There must be no dangerous rushes forward by beaters or dogs.

Never attempt to suggest that rabbits be driven to the guns. It is simply slaughter and not sport, as the wretched creatures come crawling up to the guns, and the shooter soon tires, or his guns get so hot that he has to lay them down. Walking in line over a rough grass field after rabbits have been bolted is sport, but driving to the guns is not. 


\section{Ferrets and Ferreting}

The main point to be remembered by the keeper is that ferrets are as liable to disease from bad hygienic surroundings as he is himself. Accordingly, the ferret should be assured of cleanliness, fresh air, and good food. The days of dirty, badly-ventilated boxes ought to be at an end, and as much care should be taken of the ferrret-runs and hutches as of the kennels. Ferrets must therefore be allowed plenty of pure air and sunshine. To secure this, there must be connected to their sleeping-saloons a sufficient open-air run, which should be on dry, porous, well-drained soil. It is best that these runs should be tiled over, so that they may be well sluiced with permanganate of potash solution, sanitas, or other antiseptic fluid. It is easy to arrange these tiles so as to secure sufficient drainage. The sides of the run should be high enough to prevent the ferrets escaping, yet not too high to interfere with the easy entrance of the keeper for cleaning and other purposes.

The hutch, which is pierced with holes for the proper exit and entrance of the ferrets to and from the runs, may be a box, the top and sides of which lift bodily from the ground. In may cases the box consists of but one department, but recent improvements are much more elaborate, and even go so far as to secure three compartments-one for sleeping purposes, one for feeding, and one for the calls of nature. Where such an arrange- 
ment exists it is as well that each compartment should havean easily removable "tray," so that it is not necessary to disturb the whole flooring for the purposes of cleaning, and so that the ferrets may be confined in one compartment whilst the other two are being cleaned. This cleaning must be carried out once in every twenty-four hours, and must be thorough. The runs need not be cleaned so often, but require careful inspection. Either sand or sawdust may be used for the floors of the trays.

"The food of the adult ferret consists in the main of bread and milk, or porridge or rice, but on no account should it be too sloppy. Meat is given occasionally. It must be fresh, and may consist of liver of deer, mice, rats, birds, or a piece of freshly killed and warm rabbit. This should be tied to a staple with a bit of string to prevent the ferrets from dragging it into their sleeping-place, and thus soiling the bedding" (Harting). ${ }^{1}$

Ferrets should not be fed too often; once in twentyfour hours is all that is necessary.

Working.-Ferretsshould never becarried in a bag, but always in a ferret-box, and on being brought home should always have their feet washed. It is always best, where possible, to have at least two keepers out while ferreting. If one ferret sticks, the guns may proceed to the next burrow, while the second keeper waits

${ }^{1}$ Encyclopadia of Sport. See also his volume on Rabbits, in Fur, Feather, and Fin Series. 
till the "stuck" ferret comes to the surface. If this does not happen after some time has passed, a dead rabbit should be laid at the mouth of one of the holes; if this does not succeed, the rabbit should be disembowelled and the entrails laid at the mouth of the hole, or a cartridge may be emptied of its shot and fired into the burrow. If all these plans fail, the ferret may be dug out, or nets or harmless traps may be set at several of the holes.

Neither the "guns" nor the keeper should be seen by the working ferret. They should, if possible, stand down wind and out of sight. We hold firmly that a ferret should never be muzzled, and seldom coped. A rabbit is driven to the surface better by a ferret that is free, and a coped ferret is only capable of worrying, not killing.

Diseases of Ferrets. - The commonest complaint is sweats, with symptoms of abnormal temperature, thirst, running from eyes and nose, loss of appetite, and dulness. The affected ferret should be isolated, and bathed in some antiseptic fluid, as mild boracic acid and water, or permanganate of potash. It should be well dried and placed in a clean, fresh, dry, and warm hutch. The animal should be fed on slops-fresh warm milk, arrowroot, soup, and similar foods. Whatever is used, there should be a very gradual addition of solid food to the diet as the ferret improves. A good thing is a newly killed sparrow or other small bird, given a piece at a time sprinkled with a pinch of sulphur, once in twenty- 


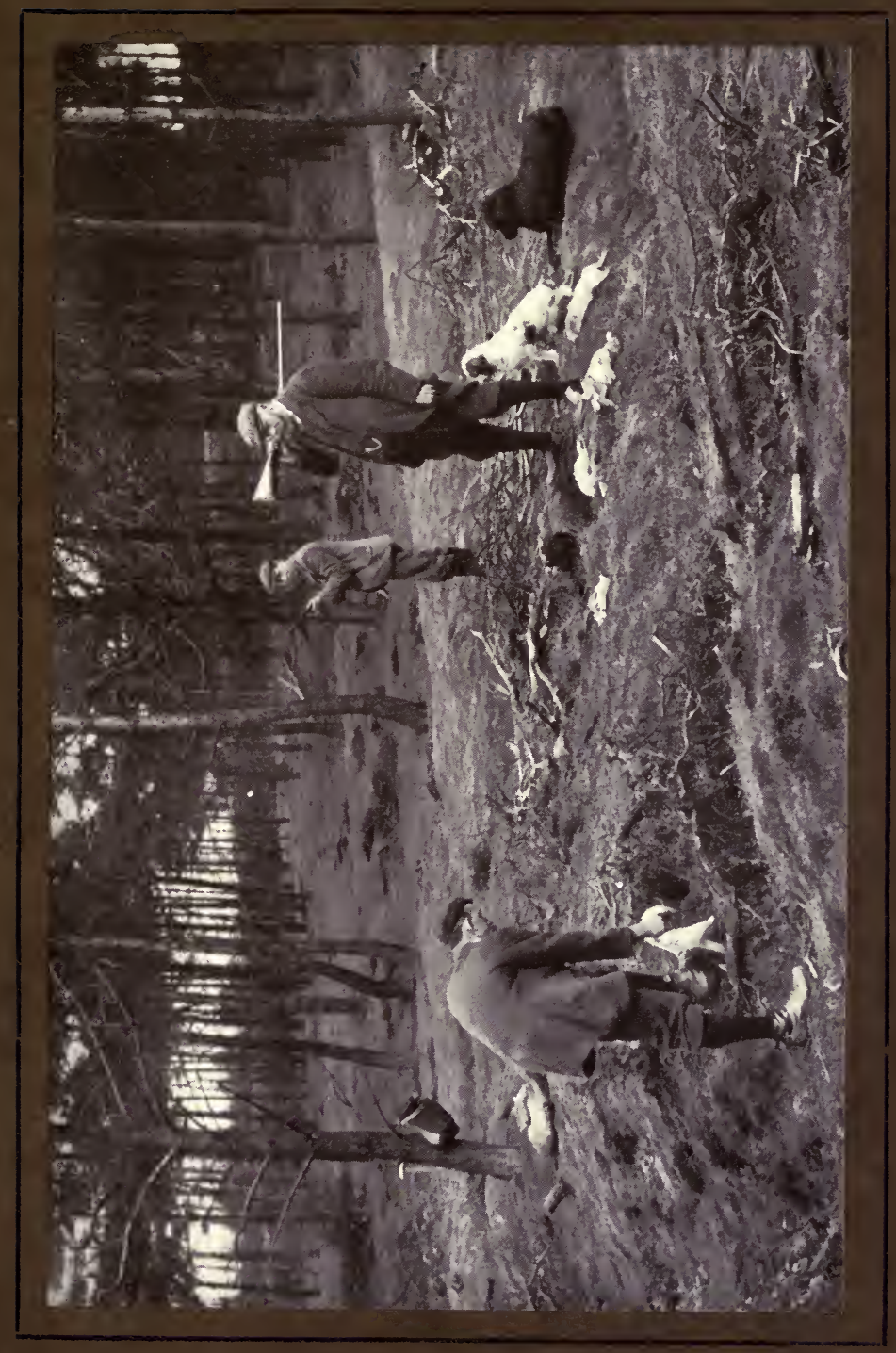


four hours. All discharges should be carefully washed from eyes and nose, and the latter anointed with vaseline.

Foot-rot-Therapeutics. - Creosote or nitrate of mercury ointment applied once a day.

Worms.-Areca-nut or Filix-mas, followed by castor-oil.

Eczema.-Cleanliness and change of hutch, washing with antiseptic fluid, careful drying, and the use of nitrate of zinc lotion.

Itch.-Some form of mild sulphur ointment.

\section{Keeping down the Rabbit}

The rabbit may be kept down by-(I) Shooting, (2) ferreting and shooting, (3) catching by a pitfall, (4) trapping, (5) snaring, and (6) netting. Of the last four methods there are endless modifications, and it will be found that most keepers have their own pet method, from which they are very loath to depart. As long as the method is legal, effective, comparatively painless, and economic, nothing can be said in its disparagement. The legality is of importance, for no one can use a spring trap to catch rabbits except $(a)$ in the mouth of a burrow, and $(b)$ unless the rabbits are taken by an owner occupying his own land. Many methods employed to take rabbits are completely ineffective, and should be immediately disregarded. Failure often results from the keeper leaving the traps exposed to view. Unless soil is sprinkled over them to hide them from 
the keen sight of the rabbit, they will be as useless as a piece of dead iron. Another cause of the ineffectiveness of a snare or trap is the taint of anything that has come from human contact. The smell of man, dog, powder, rabbit, game, hanging around a trap, is a handicap that can only point to failure, therefore the keeper must see that his hands are perfectly clean before he sets his trap, and that the latter does not come in contact with his clothes. Mr. Harting recommends that after the hands have been well washed in soap and water, they should be rubbed with mould scraped up near the place where the snare is to be set. "When it is time to put the wire into shape, and smooth out any bends or kinks in it, this should be done, not with the bare finger and thumb, but with a bit of wash-leather between them. It is easily carried in the waistcoat pocket, and a snare rubbed down with this will be found to run as smoothly as possible when touched by a rabbit. Moreover, this intercepts any scent from the bare hand. To secure the effectiveness of snares, they should beset in the morning. The evening dews are apt to preserve the scents of the keeper."

The "humanitarian" side of the question must not be neglected. Any trap or snare that catches a rabbit and causes it needless suffering and a long and painful death, must be avoided.

It will be to the advantage of the keeper to be cognisant of the best traps and snares that have been recommended by authorities on the subject. Their 
modification is endless, and from a description of some twenty or thirty, we select three or four which appear to us to meet the requirements of the keeper in the most effective, the most painless, and the most economic way.

(I) Cruickshank's Trap.-This, the latest of all traps, is manufactured by Mr. A. A. Cruickshank, Craighall Warehouse, Glasgow. The body of the trap is exactly the same in form as that of the ordinary rabbit trap. It is of Dorset type, fitted with brass mounts. It is lighter than all other traps we have handled. The spring distinguishes it markedly from other traps. It is made of fine steel, and each spring is constructed so as to fit any trap, and can be detached or attached by hand without a tool. The spring does not need a railway rail for a base to prevent buckling, as the entire pressure on removal of load passes right through the spring into the air on account of the loose socket attachment. In addition to this, as the spring terminals come close together when set, the spring, whenever the plate is touched; starts off more readily than in other types. The danger of a broken lever during frost is largely if not altogether removed by the coil spring. Experience has shown that this is altogether an excellent form of trap, and being of excellent workmanship, light, strong, effective, and durable, is certain to become popular.

(2) Burgess' Spring Trap.-This is recommended 
by Mr. Carnegie in his volume on Trapping, who appends to his recommendation this clear description of its qualities: "The spring is the most important part of the trap, is thoroughly well tempered and strong, but, nevertheless, easily pressed down when the trap is set. The flap and catch and other important parts in which most makers fail are of copper, and do not wear away like iron, nor do they rust, which would clog the trap and prevent it acting. The plate is square, with the four corners taken off, and is of zinc, being so fitted as to be level with the jaws when set. These latter are thick and rounded, the teeth fitting one into another, though not closely, a space of one-eighth of an inch being left between. The teeth should on no account be sharp or pointed, as their being so tends to break the leg and cut the sinews, thus liberating the rabbit; nor should the teeth be continued round the turn of the jaw. ... In order to prevent the rabbit, when caught, drawing the trap away, the back piece of the gin is furnished with a hole at the end, through which a chain about a foot long is attached by means of an $\mathrm{S}$ hook. The chain should have about eight links, with a swivel in the middle, and a ring of one and a quarter inch diameter at the end. It is purchasable apart from the trap, and should be well tested, as the weakness will be found where least looked for, viz. in the swivel, and this should always be examined. The ring is for a stake, which is driven to hold the trap. The best wood for this is ash, which should be cut in lengths of eighteen 
inches, and split, then rounded off to the required size, fitted tightly to the ring, driven on to within one and a half inch from the top, and be overlapped by this part, which ought to be left unrounded as far as the ring comes."

(3) Brailsford Trap.-This is a trap to catch rabbits alive, and is manufactured by Messrs. Arlingstall \& Co., Warrington. The following description is taken from The Field, being an extract from a letter from Colonel Butler, of Brekenham Park, Suffolk: "It consists of a wire cage, very strongly made and open at both ends, the door being kept up by a simple method of setting. There is a treadle made, and as soon as that is touched the doors close and the victim is imprisoned. . . . In setting them in runs, under shelving banks, or by the side of wire-netting, I usually make wings at each end of fir boughs, or something of that kind, to guide the animal in ; but when set at drains or holes, it is only necessary to make a wing at the end farthest from the hole, the trap at the other end fitting close up to the entrance of the drain." This trap, it may be added, is extremely useful not only for catching rabbits, but all forms of vermin.

(4) Mr. Lloyd Price's Snare. - "Select the narrowest part of a frequented run, one well covered with herbage, if possible, to conceal the apparatus, either on the flat, or, better still, on the side of a hill. Drive the big peg firmly into the ground at the side of the run, let

${ }^{1}$ Encyclopadia of Sport. 
this be well hidden by the grass, heather, or what not ; then give a hitch or bend to the centre of the wire to hold the same in a loop just four inches in diameter. Next, stick the carrying peg in the ground to hold the loop (which should just easily go round your closed fist) at an acute angle to the run, also in the grass at the side, or otherwise concealed, four inches from the ground, and with the runner of the noose on the low side, so that the loop may run easily along the wire. Properly set, the catchloop should stand up at right angles, or nearly so, from the support peg, elevated above the surplus wire. If the latter be at the top, the noose will not run so freely; this can advantageously be hidden with bits of cut grass, leaves, etc., as also may the string which connects the wire with the holding peg."

Netting may be practised either by the small bag net attached outside a rabbit-hole, or by the long net. The first is used, of course, with a ferret. The long net is familiar and needs no description. It is used outside covers and is worked at night.

\section{Poaching the Rabbit}

The planting of thorns near to rabbit runs is of value in counteracting net-poaching. Where the long net is used by poachers or farmers, it is as well for the keepers to forestall them by arranging a shoot in this method: Have a shoot with the long net and let the rabbits away, then a second shoot on the same principle, and it will be 
found that fewer rabbits appear. The third shoot can be safely left to the poachers or farmers, for they will get nothing.

Note.-The keeper should never forget that it is inadvisable to put fur and feather into the same game-bag or pannier. He should also remember to empty the bladder of the rabbit immediately it is picked up. 
NOTES 


\section{CHAPTER XIII}

\section{The Pheasant}

THE science of rearing and "showing" pheasants has produced such an extensive literature, and has become such an elaborate affair, that it is absolutely impossible for such a book as this to attempt to deal with the question in any but a summary way. To enter into the details of "showing" pheasants alone would require the whole of this book and more, and we can only repeat what we said when dealing with grouse-driving - that every man who desires to reach to any perfection in the art and science of the matter must have recourse to the books of the great authorities. In the rearing, showing, and shooting of pheasants, more than in any other branch of sport, it is advisable that a small reference library be at the command of the head-keeper, and it is for the master to see that advantage is taken of the privileges of this literature. Although we have indicated more than once the leading writers on sport, it may not be out of place here to enumerate the books of reference which we have found most useful in our study of pheasants.

(I) Experience-by far the best book.

(2) The Encyclopadia of Sport. 
(3) Shooting, by Lord Walsingham and Sir R. Payne Gallwey (Badminton Library).

(4) The Pheasant, by A. Stuart Wortley and others (Fur, Feather, and Fin Series).

(5) Practical Game Preserving, by W. Carnegie.

(6) Sport, by W. Bromley Davenport.

(7) The Gamekeeper at Home, by Richard Jefferies.

(8) Pheasants, by W. B. Tegetmeier.

(9) Letters to Young Shooters, by Sir R. Payne Gallwey.

(I0) Shooting, by Horace Hutchinson and others.

(I I) The Forester, by Brown and Nisbet.

(12) Sport in the Highlands and Lowlands of Scotland, by Tom Speedy.

(13) Birds of Norfolk, by Henry Stevenson.

With these at his command, no keeper can say that he has not heard the best words on the subject, and will hardly require the more or less superficial study which we propose to make.

On no subject of sport is there less room for being dogmatic than on the rearing of pheasants. Experience is the best teacher, and methods vary according to the climate, position, particular breed of birds, and many other circumstances, which alter methods in different localities. The one subject which must be insisted upon, and on which there is no difference of opinion, is cleanliness, pure water, pure food, and above all that the ground on which the pheasants are reared must be clean, and not overstocked with chicks. Coops should be 
moved daily, and the same field should never be used for rearing two years in succession.

The keepers' duties in relation to the pheasant differ enormously. They may be connected with a shooting in which the pheasant is only regarded as part of a mixed bag, or they may be concerned with rearing and "showing " on an elaborate scale. It is in the latter case that the keeper's knowledge of the literature of the subject will be of importance. In the former case, where he is only possibly concerned with a few head of wild birds, he will have little to learn, and there will be small need of elaborate studies in rearing and "showing." In these cases his beating will be simpler than the beating of partridges, and he will only have to bear in mind the general rule affecting flanks and stops. But it is altogether a different matter when covert shooting is conducted on a scale of great elaboration.

\section{Pheasant-Rearing}

Bearing in mind what we have already said as to the impossibility of dealing with the question at any length, let us take a view of the main points that have to be taken into consideration.

(I) There are several ways advocated of dealing with the question of the proper supply of eggs for the next year's sport:- $(a)$ In some estates the procedure is simply to attract the hens that are left after the shooting is over, by a little judicious feeding, and to allow breeding to take place in a semi-wild condition, and then 
simply to collect the eggs that are laid. (b) Another plan is to utilise a particular covert as the breedingground; this covert only being protected in the sense that a certain amount of wire fencing surrounds it, otherwise there is no penning nor other form of artificial enclosure. (c) A third and more general way is to collect a certain number of hens before the shooting begins, and either enclose them in the kind of covert mentioned last or in enclosed pens. (d) A modification of this is to leave the collection of the hens till the shooting is over. The great objection to the latter practice is that some of the hens may have been " peppered" by shot, and may have received injuries to the maternal organs. There is also anotherpoint in favour of taking hens before theshooting begins. By so doing, one is rid of the incessant fear that too many hens will be killed, and that there will not be enough left for the mews.

Whether it be required to secure hens for the mews or not, every keeper should ascertain the condition of his stock as soon as the shooting season is over. This is easily done by a little regular feeding. If there be too many cocks, he may exchange them for hens with a neighbouring keeper, and vice versa. If this practice be not convenient or possible, the keeper should indicate to his master the fact of this superabundance, and if a large number of hens are not to be procured to counteract this disproportion, some more cocks should be killed.

But whether there be disproportion or not, the general game law as to the value of fresh blood must 
be remembered, and as much care taken in procuring pure breeds as in the case of rabbits or partridges. Crossed breeds or weaklings should on no account be introduced. LordWalsingham supports the contention that " there is no better breed than the true Phaseanus Colchicus, commonly known as the old-fashioned dark variety without a white ring on the neck. These are free layers and good mothers-straying less from home than the paler plumaged varieties more recently introduced. They are quite as hardy, and fly at least equally as well. There are few places in England now where some traces of a cross with $P$. Torquatas, the ring-necked Chinese bird, are not to be met with, but, in the opinion of the writer, the cross-bred bird is not so worthy to be encouraged and propagated as are those of the old, dark, pure breed." The exchange of birds and eggs should be frequent-if possible, of an annual occurrence.

If the hen birds are to be kept in mews instead of being allowed to breed in coverts, more cocks should be supplied than in the more natural state. There should never be more than six hens to each cock in the mews, and there should be every facility for the wild cocks to get to the enclosed hens. The mews, therefore, should not be shut in at the top. In constructing the mews, the main point to be remembered is that they should be absolutely closed in for at least $3 \mathrm{ft}$. from the ground, so that the pheasants may be free from disturbance and annoyance from without. The birds should have plenty of space, air, and light, and the ground on which the I 8 
mews are constructed should have a light, porous soil. If the latter condition be not obtainable the ground should be dusted with sand and lime. Pens are constructed either as separate domestic establishments, containing one cock to several hens, or are made to hold as many birds as one requires, the proportion of cocks and hens being maintained as in the small pen. Half an acre of ground accommodates about forty hens. If the pens are constructed in covert, the place chosen should have plenty of good undergrowth; if they are placed in the open the ground should be planted with shrubs of varied kinds. Spruce and privet are generally recommended.

In feeding the birds in the mews, care should be taken that this is always done by the same person. He should on each occasion be dressed in the same type of clothing. No strangers should be admitted, and whether feeding thehens in mews or covert, or the young broods at a later period, there must be no attempt to call the birds by whistling to them when about to distribute the food. This bad habit tends to domesticate the birds to a marked degree. It is to be remembered at this point that if open coverts are used, on no account must birds be put into coverts in which they will not naturally stay. Select a covert which they naturally draw to and stray to. The general law that it is the duty of the keeper to assist, and not to thwart, the instinct of the bird must be observed. It will be found that pheasants naturally select coverts which haveplenty of light, plenty of shelter, that are dry and warm, and 
have well-drained, porous soil, and which face to the south or south-west. This fact will lead the keeper to understand that he must on no account select ground which is cold or damp, which is exposed to the north or the east, and which is dark and dreary. The law which applies to pheasantries also applies to the ground on which the coops are placed.

The food of the penned hens should be of soft consistency - the ordinary poultry food (barley-meal and biscuit-meal) in the morning, and dry mixed grain in the afternoon. Some green food should be given occasionally. All food, whether for old birds or for young, should be mixed in the morning. On no account should the keeper perform this duty at nighttime. Stale food is a marked cause of disease. Too much maize should not be used, it makes the birds heavy, yellow-fleshed, and not agreeable to eat-vary feeding with light barley and oats and very little maize.

Great care should be taken that the ground of the pheasantries (and likewise the ground on which the coops are placed) is free from vermin, and is not allowed to stale. In the case of the pens and mews, these should bepurified by asprinkling of lime and sand, and if feasible the ground should be changed every few years. Stale ground is an important cause of mortality. Some authorities recommend that powdered oyster shells be placed in every pen.

About the beginning of April the keeper begins to collect his eggs, and he will continue to do so for about 
a month, and he can turn out his penned birds by the middle of June. By that time he will have his fostermothers ready. Game-hens are the best, and of these the black-red game-hen is to be preferred above others. If these are not to be obtained, small hens should be selected, of which buff Orpingtons are probably the best mothers. They should all be strong birds, absolutely free from disease. He should carefully retain the eggs of these hens for some eight or ten weeks before the pheasant hatching season, for the purposes of food for the pheasant chicks. The roosting of the game-hens is of importance, care being taken of them as consistently as of the pheasants. The sitting hens must be allowed an early morning run on the wet grass, so that they may damp their breast feathers. This markedly assists in the hatching process. Some authorities recommend that where the hens are kept in closed yards the eggs should be sprinkled with tepid water at the time of the morning meal.

In collecting the eggs it is wise for the keeper to mix some "wild" eggs, and some purchased or exchanged eggs, with the ones collected in the pens. All nests that have been built in exposed or dangerous places should be denuded of all their eggs except one or two. Leaving the latter is a stimulus to the wild bird to go on laying. Otherwise she would as a rule desert her nest. Of course when the nests are left they should be carefully watched.

Suitable ground for the coops having been selected, 
the eggs are put under the game-hens, whose nests should consist of a square of dry sod or turf. On no account must the ground have been used the previous year. Ground for coops should be changed every season. Lime, gravel, and sand should be freely scattered about, and a liberal supply of cover in the shape of fir branches be placed at intervals, to afford temporary shelter to the chicks from the inroads of their enemies. The presence of the "cuckoo-spittle" should be noted. It contains an insect which is deadly poison to the young chick. One acre is sufficient for a hundred birds. The sitting hen should not be confined to the coop. This method of confinement, being a severe tax upon the nature of the bird, is unnecessarily cruel. Not only is this so, but the method deprives the chicks of their natural protector, and prevents the hen from cleaning and dusting itself, with the result that it becomes infested with vermin, which are conveyed to the chicks. It should be tethered with a cord about a yard and a half long. This allows sufficient room for the hen to move about and to perch on the top of the coop. When vermin approach, the hen is able to warn the chicks by her cackle, and they have a chance of running under her wings for protection. The hen must, of course, be shut into the coop at night time. When an incubator is used, the eggs are removed from the game-hen as soon as they begin to chip and are placed in the incubator, and when hatched the chicks are removed to the tray above. All the eggs must never be removed from the nests at the same 
time. In putting back the chicks there is no need to select special chicks for special hens. Chicks must never be let out very early if there is frost or heavy dew on the grass. Remember, covers should be kept quiet, or birds will leave them; no straydogs, or shooting rabbits round covers at evening; no broken fences to permit of cattle straying in them. Keepers on their rounds need not leave the rides for fear of disturbing the game.

Encourage plenty of undergrowth, wild berries, and hazel for natural food in coverts. Where there are none, transplant in autumn or spring. How many keepers trouble about this?

Mr. Carnegie's Table of Food for Young Pheasants. See opposite page.

Other authorities recommend hard-boiled eggs passed through a sieve with a little specially prepared biscuit-meal or oatmeal, as the food of the young birds. No water should be given at any time. The moist food supplies enough. No food should be given to the chicks for the first twelve hours after hatching. A good supply of insect food, as in the case of young partridges, is of great benefit, and when this is not obtainable maggots maybe given. These may be obtained from the bodies of dead crows.

But whatever plan of feeding is adopted-and the variations are too elaborate for us to dwell upon them in detail-war should be severely waged against the habitual extravagance connected with pheasant-feeding. Overfeeding and waste are rampant in most places 


\begin{tabular}{|c|c|c|c|c|c|}
\hline 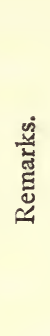 & 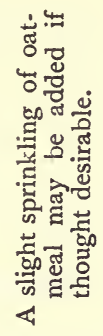 & 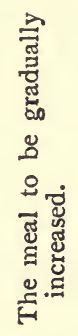 & 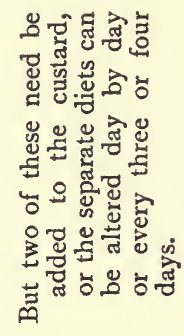 & $\vdots$ & 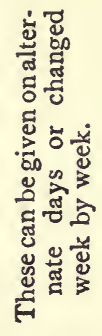 \\
\hline 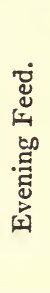 & 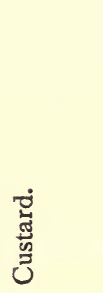 & 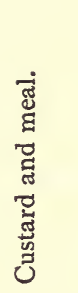 & 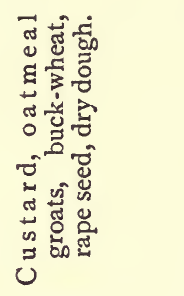 & 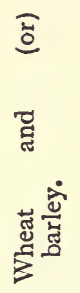 & 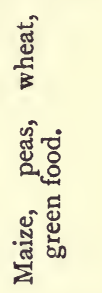 \\
\hline 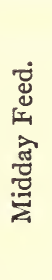 & 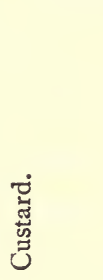 & 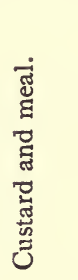 & 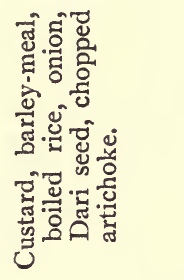 & 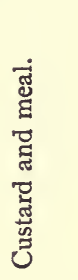 & 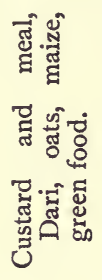 \\
\hline 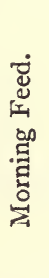 & 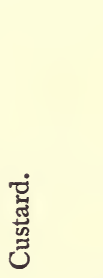 & 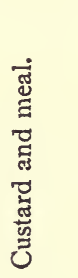 & 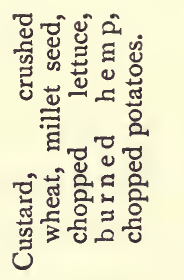 & 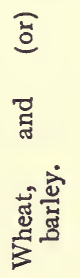 & 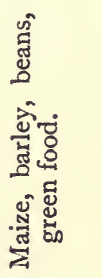 \\
\hline 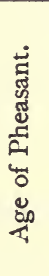 & 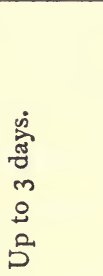 & 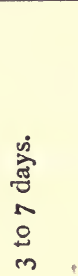 & 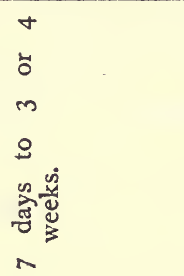 & 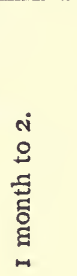 & 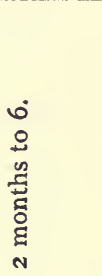 \\
\hline
\end{tabular}


where pheasants are reared. Most birds get 40 per cent. more food than is necessary, and the keeper must combine a sense of responsibility with his judgment in discovering the right mean. No encouragement should be given to the practice of habitually buying "patent" foods. The keeper should make and prepare his own food.

When theyoung pheasants are old enough the coops and chicks are removed to the covers.

\section{Poaching the Pheasant}

Watching must be carefully carried out by night and by day, and the possible depredations by foxes and poachers dealt with. If trespassers or night poachers are suspected in any covert, threads should be stretched in the evening across any likely paths of access, twelve inches or so from the ground. Their condition in the morning will warn the keeper as to the presence of poachers, and a careful look-out must be kept for the next few nights.

Alarm guns, bells, etc., may also be used. Artificial pheasants nailed to the branches of trees afford a good plan of thwarting the poacher.

A strict look-out should be kept for any suspicious carts that may be loitering about the ground. It is as well that the keeper should gallop on horseback round the roads and over the estate every evening.

Depredations by foxes or dogs during pheasantrearing can be frustrated by stretching several lengths 
of string, with small bells hung on to them at intervals, about nine inches from the ground, all round the approaches to the coops. The fox is sure to scent a trap and clear off. If the string is soaked in carbolic, renardine, tar, or some other high-smelling liquid, so much the better. In hunting districts, where foxes are plentiful, this plan is very necessary, and is thoroughly efficacious.

An excellent plan to trip up poachers is to have wire instead of string stretched across all approaches to the rearing-ground. Another practice is to surround the coops with a stout wire, and to attach to it one or more dogs, so that each dog has a free range over a considerable stretch of ground.

On some estates one of the night watchers carries a horn, and blows on it every quarter of an hour or so, for the purpose of driving off foxes.

It is very wise for the keeper to occasionally go round the hedgerows with a spaniel and drive in strayed birds.

\section{Shooting the Pheasant}

The most important duty of the keeper on the morning of a shoot is to have his beaters out early, and drive in all the surrounding country so as to have the birds in the coverts, and, as he does this, he should have a sufficient number of boys or men carrying a yellow flag to act as stops. These boys should be provided with a good lunch, as they may have a long wait, 
and cannot be expected to remain at their post unless they are fed. Stops should be left at all the likely places where the birds are likely to leave the covert. They should carry yellow flags so that their position may be known, and they may join the line of beaters when these come up. Without this, the day's shoot will be an absolute failure, and the birds cannot be expected to be found in the coverts. It is better that they should be instructed to keep absolutely quiet. A very occasional tap with the stick when the birds are making for the open should suffice to keep them back. If the coverts are small, it will be sufficient if the stops show themselves and make no noise whatever. All outlying woods should be driven in to the main coverts where the birds are to be flushed. A large number of stops are necessary, and they should be in no way grudged, as they are the most important essential to a successful day's shooting. In a well-known detached covert in Lincolnshire, after the birds are driven in, the wood is practically stopped all round; it takes two hours to drive the maze and surrounding coverts into this wood. Besides the guns over which the birds are to be driven there should always be two placed behind the beaters to get those that go back.

There are four cardinal principles in the beating of pheasants to the guns which must be carefully imprinted on the memory of every keeper-

(a) Push pheasants as far as possible on their feet and bring them back on their wings; 
(b) Drive pheasants on their feet away from home and then flush them homewards;

(c) Flush pheasants at a considerable distance from the guns;

(d) Flush pheasants from a higher ground than that on which the guns are placed. The keeper who attempts to drive the birds against a gale of wind should be conveyed at once to the nearest lunatic asylum.

Now these cardinal principles are enumerated on the understanding that the keeper is expected "to show" his pheasants in the best way possible. That is, he is to bring them to the guns flying high and fast; he is not to present a number of "flapdoodlers" and lowflying birds. The latter may please certain people who are quite satisfied if they bring the thing they aim at to the ground, but it is not sport. The great boast of every keeper should be that his birds fly higher than most and require some "stopping." Accordingly let him remember that to produce such a result he must do something more elaborate than send his beaters in at one end of a covert and march them in a straight line to the other. He must, in fact, push his pheasants on their feet to a flushing-point and then allow "the trouble" to begin. In saying as much, it will of course be at once recognised that this can only be done by careful arrangement of covert, beaters, stops, and guns, and will require considerable study and patience. 
Now to obtain the desired result on the cardinal and classical principles we have summarised, he must first think of the flushing-point, which may be-

(a) A detached piece of covert like the famous Scarborough clump at Holkham;

(b) A specially planted piece of covert at one of the corners of the main coverts ;

(c) A turnip-field some little distance from the main covert.

The Scarborough clump at Holkham produces such excellent results that the practice followed there is to be recommended to the consideration of all keepers, and in following the Holkham methods he should remember certain important rules-

(a) The detached covert must not be larger than the main covert ;

(b) The end of the main covert must be thinly planted and must not be fenced in; if it is fenced there must be an open space immediately in front of it.

(c) The undergrowth in the detached clump must be good, and not hollow at the bottom. Birds are thus prevented from running and crowding together and rising all at once or in great numbers.

Having these conditions, the beaters must enter the main covert at the end farthest away from the detached covert, flankers must be placed, both men and guns, and the beaters must advance. As the birds 
are pushed forward on their feet, the beaters must not get too close to the running birds. Pheasants can be driven anywhere if kept on their feet. If there is a danger of too much squashing together, or a threatened flush, the beaters must be halted. As the beaters advance, all thick cover must be properly beaten, especially bramble bushes. Beaters have a habit of neglecting these from fear of injuring their clothes. Every beater should therefore wear a smock and gaiters. In driving the birds from the main covert, the beaters stop about one hundred and fifty yards from the end of the covert, which should be quite open, and begin to make a great noise ; this drives the birds across the open space to the detached covert, and they are now ready to be flushed. Stops are placed around the detached covert, each man being ordered to beat two sticks together to prevent birds collecting in his vicinity, and for his own safety. Guns are placed in single or double rows, as desired, in the space between the two coverts-not nearer than eighty yards to the detached covert-and the flushing begins by a keeper entering the clump and putting up birds one by one or two or three at a time. After this has gone on for some time, all the beaters enter, and, moving slowly across the covert, drive out the birds, which, passing over the guns, take their height pretty much at the level of the trees of the home covert, from which they had been beaten. A modification of this plan is for some of the beaters, after leaving the main 
covert, to cross the open space and be lined facing the detached clump, that is, some distance in front of the guns. This will ensure the birds passing over their heads, and gives the guns a better chance of high and strong-going birds.

(2) Where it is proposed to follow the method of driving the birds into a corner of the main covert, the latter should be worked in a series of beats until the whole of the birds are at the flushing-point. The cover of the flushing-point must be attended to as carefully as in the detached clump, and from it there should run a narrow strip of similar cover along the whole face of the wood. In this case there must be a drive or open space made inside the cover, where most of the guns are placed. The birds on being flushed will fly homewards, as in the first case. Stops as before.

(3) The third method we have indicated consists in driving birds into a turnip or potato-field some hundred yards in front of the main covert, stops being placed at the end and sides of the field. The guns stand in the open between the main covert and the field, and some beaters advance into the field some sixty or seventy yards and halt. The rest of the beaters then go round and bring the field back in the homeward direction. The birds rise, pass over the heads of the stationary beaters, and make for the covert, passing in their flight over the guns.

If a keeper is obliged from unforeseen circumstances to place the guns instead of the host, he ought 
to post them a good distance from the covert, so as to give them a chance of getting good birds instead of the nasty skinners which they are sure to get if they are close to the covert side.

These three methods of "showing" the birds may serve to illustrate the cardinal principles we have enumerated, and will suggest to the keeper who is ignorant of the matter the advisability of modifying methods which are now regarded as prehistoric. $\mathrm{He}$ will find the details of each of these methods described, with some slight modifications, in Mr. Stuart Wortley's epoch-making volume on The Pheasant. Even where there is no artificially arranged flushing-point, the birds may be so driven as to secure them being flushed from a higher plane than that on which the guns stand. For instance, where the covert is lying on the side of a hill or gentle slope, the birds should be flushed from the highest point, never the lowest. In those cases where coverts are very much on the same plane, and noparticular flushing-point is used, it might besuggested that a stretch of wire-netting twenty-five yards from the end of the covert will make the birds rise, and have time to get above the tree tops before they reach the guns.

When itisabsolutely impossible to conduct pheasantshooting on these scientific principles, from want of suitable coverts or from other reasons, it might be as well that near to the end of the coverts three parallel rows of wire-netting be arranged, with an opening in 
the centre of the two posterior ones. As the pheasants are pushed forward some will collect behind the first netting, some behind the second, and some behind the third. Each division can then be flushed separately.

In some places where they have small pheasant shoots, matters are improved, and pheasants are shown better, by prefacing the first covert shoot by a dummy one, a sort of dress rehearsal, a few days before. Keepers are placed with blank cartridges, and the birds are sent over the guns once. By this method the headkeeper is able to note the flight of the birds and deduce therefrom the proper position of the guns, and in addition to this the birds fly higher when the real "trouble" begins.

In addition to what has been said, the following practical points may be indicated :-

(I) Sewin may be used as an excellent form of stop, both for hares and pheasants.

Sewin is made by fastening white feathers and scarlet tape at intervals of a yard, and ferret bells at intervals of five yards, on to white or yellow cord, which is placed on sticks some two and a half feet high, firmly planted in the ground. The sewin is continually jerked by a beater, specially told off for the purpose. It may be used both inside and outside of the coverts. The sewin is kept on a reel, and is wound round an iron frame. The reel, the frame, and the sewin are supplied by well-known firms, and the Army and Navy Stores. 
(2) Late in the season stoppers are even of more importance than beaters. All stops should, of course, get into position in the early morning, long before beaters start and guns begin to fire.

(3) Always shoot the covert that has the most birds in. Do not keep to a stereotyped habit of shooting coverts whether birds be in or not.

(4) Always shoot the exposed coverts early, as birds stray to warmer quarters on the fall of the leaf.

(5) All things being equal, outlying coverts proximate to other shooting-ground should be shot early to prevent the loss of birds by straying.

(6) No wild or untrained dog should ever be allowed in the coverts.

(7) All birds must be picked up as they fall. One or two keepers with dogs following a mixed line of guns and beaters are useful. A keeper or keepers, in fact, should always be behind guns. In the clump or detached covert system they should be just inside the main covert.

(8) The coverts should be searched carefully with dogs, preferably on the same day, or the day after the shooting, for the purpose of finding any wounded or dead bird that may not have been picked up. The keeper should be allowed to take a gun and shoot any birds that show signs of being wounded.

(9) All birds should be counted at the end of each beat. This will counteract any tendency to theft on the part of the beaters. 


\section{NOTES}




\section{CHAPTER XIV}

WILD DuCK

By Lord Malise Graham

DuRING the past few years we have noted the large bags of wild duck it is possible to obtain by careful rearing and good management. Although the number of wild fowl can hardly be said to have decreased, yet there is little doubt that in some marshes where, many years ago, large flocks of wild duck used to collect, there is scarcely one to be seen. The reasons for this are numerous. The most important probably is, that as our population increases, wealthy sportsmen and landowners are tempted to seek seclusion and build their mansions in far-away spots which have always been the haunt of the wild duck. These birds, being of a shy disposition, seek other pastures, and the only way to lure them back is to breed and rear by hand others which will act as decoys to their more nomadic brethren. At Netherbyand other places, enormous bags have been realised, the size of which would hardly have been credited ten or twelve years ago; moreover, the trouble taken is well repaid by the excellent sport these birds afford; and the difficulty involved in killing a really 
high duck is sufficient to satisfy even the most exacting sportsman.

The common wild duck are fairly plentiful all over the British Isles; they are generally to be found in lakes, ponds, rivers, or other watery places. The male, commonly known as the mallard, is a singularly beautiful bird. The head and upper part of the neck are of a dark green hue; the lower part of the neck, which is separated from the upper part by a white ring, is of a greyish brown colour; the breast above is of a deep chestnut, below of a greyish white; the back is greyish brown. The wings, which extend to nearly $3 \mathrm{ft}$., are of a rich purple colour merging into black; the greater wing coverts have tips of a velvet-black, with a bar of white near the end, and the lesser wing coverts are of a greyish brown. From the end of May till the beginning of August the male adopts the dress of the female, and does not completely assume his own brilliant plumage till the beginning of October. The female is smaller than the male and is of a brownish hue, the back being blackish brown and the breast pale yellowish brown; the wings brown, with a little green. The male bird has a tail of twenty feathers, the four centre feathers of which are curled up : they are of a greenish black colour, the others being greyish white. The female has a tail of brown, the feathers margined with reddish white. The young birds, male and female, known as flappers, resemble each other till after the first moult.

The young wild duck is easier to rear than the young 
pheasant, and the expense is small, but certain precautions have to be observed, or the result will mean failure. The eggs can be bought nowadays at comparatively low prices, and, having once been bought, there is no necessity to purchase more for the next season, as the females reserved for laying will lay quite sufficient. But supposing, as will probably be the case, that the eggs are to be collected on the estate and along the marshes, it is not necessary to consider the question of purchase. The eggs are usually to be found in the rushes along a river bank or in an open field. The nests have even been found in thick trees, and this is not such an uncommon place for a wild duck to build in as might at first be supposed, especially if the trees are situated near a river bank. I have found a nest two years in succession in the same tree as a jackdaw had built hers. To secure the eggs, in this case, is, however, rather a severe test of the agility of a keeper. The eggs, by the way, are of a pale green colour, and are usually eleven in number.

Having procured the eggs, the treatment is much the same as it is for pheasants, but ducks' eggs require to be damped with water more frequently, as is natural, considering that the female duck would always return to her nest with her breast feathers wet. They take twenty-eight days to hatch, and on hatching, the hens, ducklings, and coops should be placed on some sheltered grass field. The ground selected should be dry, and should be wired in, as the ducklings are inclined to 
wander. After a fortnight or three weeks the hens may be removed, but the coops should remain, and the young birds should be regularly cooped up at night, and also during the day if it be very wet. It is important to ensure that they have plenty of ventilation when in the coops. It is essential at this time that the ducklings should not get into any water for swimming, as they will be found to develop cramp and rheumatism: large pans for their drinking-water should also be avoided, in case they get into them, and, when the water is done with, the pans should be emptied. As regards feeding, it is important that they should have plenty, but it must be of the right sort; they must be fed regularly when very young - five times a day, three times in the morning and twice in the afternoon. The food which is most highly recommended is a meal specially prepared by Messrs. Gilbertson \& Page, Hertford. It should be mixed with a little water and given to the birds warm for the first fortnight; after that they may have it cold. No other form of nourishment is required, and if given regularly the birds will be found to thrive on it and grow rapidly. After a fortnight, three times a day is sufficiently often to feed them, and this may in turn be decreased to twice a day. When eight weeks old, the birds may be taken to the stream or water which is intended for their permanent home, and fed twice a day as before. After a time they will become accustomed to their new surroundings, and then they need only to be fed once a day, in 
the morning. The soft food should, however, be continued for some time after removal to the water, and a few coops should be taken to the water's edge. It should be borne in mind that everything possible should be done at this time to accustom the ducks to their new surroundings, to give the place a homelike appearance, and to ensure their remaining in it. A few pinioned ducks and good food will do more to attain these objects than anything else; moreover, other birds will be attracted by their calls, and later on in the season, about evening feeding-time, many may be shot coming in to join their companions. After the ducks are a month old, oatmeal may be added to the prepared food, to make up a more substantial meal, and the birds should always be let out of their coops early in the morning before the dew is off the ground, as they will then amuse themselves bycatching the worms and slugs. After it is desired to give up the soft food, Indian corn or maize will be found the most suitable diet. This should be supplied regularly once a day, in the morning, and thrown near the water's edge. There are many other forms of food, however, such as acorns and the dried insides of rabbits, which if chopped up will be found most appetising and a pleasant change of diet. The great enemy of the duckling is the rat, and these voracious animals are sure to be found wherever there is maize; great pains, therefore, should be taken to kill them before putting down the ducks. About the time of the harvest the ducklings will be able to take care 
of themselves, and will fly away in the evening to feed on the corn. If the keeper blows a horn when he feeds them, they will get into the habit of returning to their old feeding-ground when they hear the sound, and this custom may be of use later on, when the horn will summon them to sterner realities than those of their morning meal.

It is about sunset that some of the best sport with these birds may be obtained. The wild duck will congregate at dusk in some pond, and if the right place be found, the air will be thick with them flying to and fro for about twenty minutes. This period of flighting, as it is called, rarely lasts for more than half an hour. The best way to find out the haunts of the duck at night is to walk round the leeward side of the ponds by day, and observe if there are any feathers lying on the edges. A field of stubble in flood is a certain place for the duck to feed in. As wild duck always settle in the water against the wind, it is generally found best to stand with one's back to it, as a good shot is then afforded as the bird comes down to alight. Excellent sport may also be obtained in the same way at dawn. The duck all fly back to the lake or water where they live, from the frelds or marshes where they have spent the night in feeding. It is necessary, therefore, to find a spot where they all cross over, to select a good place behind a stump or some other natural cover, and to be there about twenty minutes before sunrise; they will fly over the ambushed enemy in twos and threes, and 


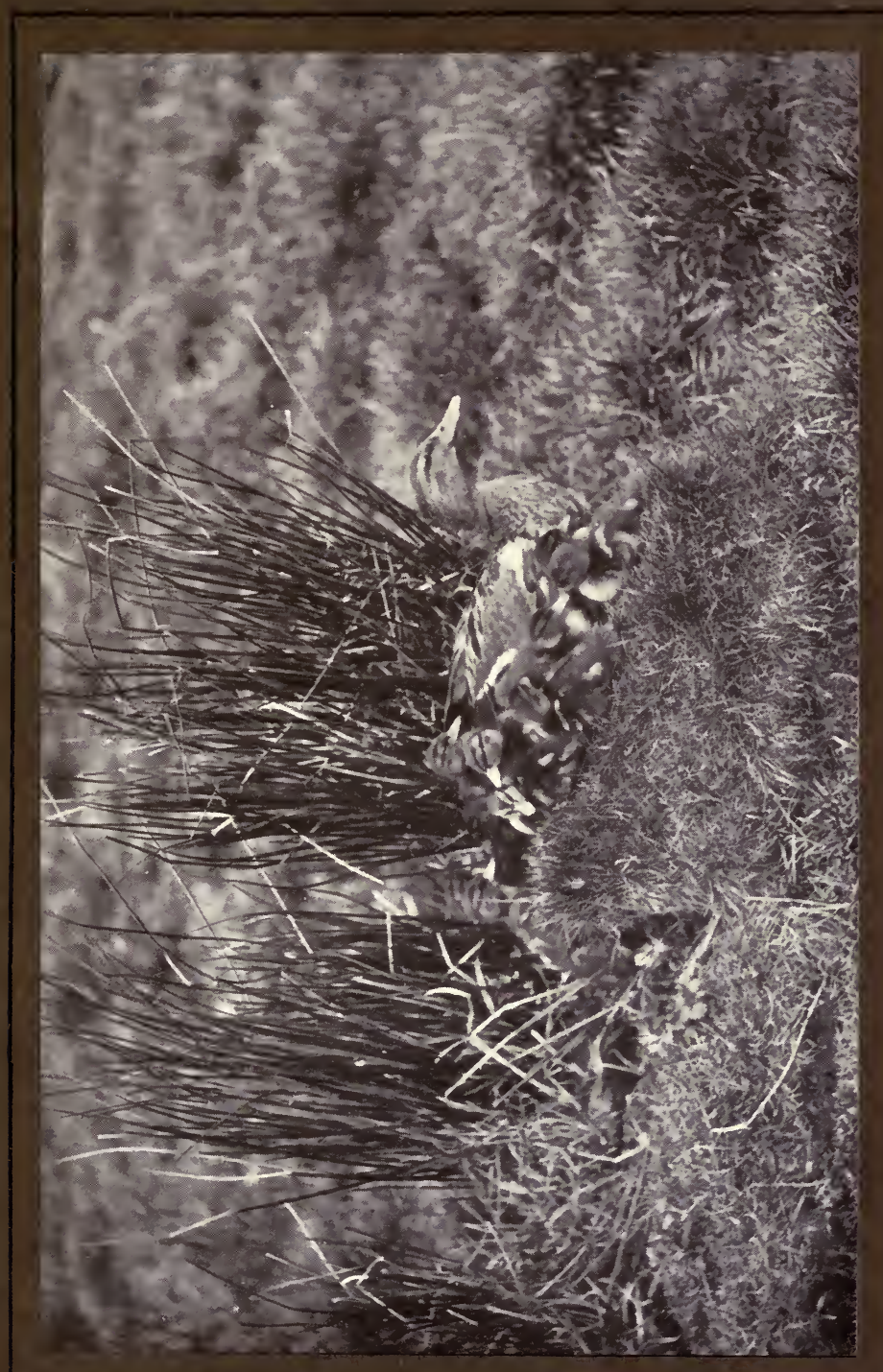

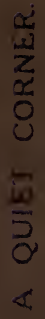


even in large flocks, and give him plenty of shooting for about a quarter of an hour. For this sport a quick eye and good hearing are essential, as the first indication of the wild ducks' approach is usually the whistling of their wings, especially on a still day. The mouth of a river, where it runs into a lake, is an ideal place for "flight-shooting," and every variety of wild fowl can be shot in this way, as, during stormy weather, wigeon and teal will often come inland to feed, the former of which can readily be distinguished by their shrill whistle. The more stormy the night and morning, the better chance one has, as the birds fly lower, and are not so easily frightened away by a shot.

Nowadays, when duck are so much reared by hand, it is possible, as has been explained above, to keep them near the streams or ponds where they have been brought up. One rule, however, should be observed with regard to shooting wild duck if they are to be expected to remain, i.e. not to shoot them in or near these streams where they have been reared. Let these be sanctuary, as it were, for them, and then they will be found to return to these places again in the evening, as if being shot at were the most natural and harmless thing in the world. Supposing that there are two or three of these sanctuaries (which there should be if there be a large number of birds), let a man be stationed near each to frighten the birds away as they try to settle; then they will fly round and round, gradually rising higher in the air, and will give the guns plenty of shooting for 
two hours or so. The guns should stand in good high butts, circular in shape, made up from fir branches, or some such other natural cover, lined alongside a wood for preference, so that the birds may be shot as they top the trees. Of course, a great quantity of duck are required for this form of shooting, and there are few places in England at present where it is possible to enjoy the luxury of a duck drive; though, probably, in a few years it will become a much more common pastime. As was mentioned above, a horn is a very useful implement for calling wild duck in, and it is astonishing with what readiness they answer the call when they become accustomed to it.

Another method of killing wild fowl is to stalk them over a river bank and shoot them as they rise. They afford easy shots if successfully stalked, but half the pleasure lies in approaching them without giving the alarm, as they are very wary birds, and their sense of hearing on a still day is little short of marvellous. A useful thing to remember is to approach them, if possible, from the side from which the wind blows, as they rise against the wind and their breasts afford a good and vital mark. A young wild duck, bred in the river, has a great enemy in the pike. It is extraordinary how many birds this voracious fish can account for, and keepers can very well spend any spare time they may have in the summer in catching them. Even in innocent-looking ponds these fish may be found, and I have known the young duck disappear from a pond in 
a seemingly inexplicable manner, and yet the cause was not very far to seek, for eventually several large pike were taken out of it. The only way to catch these fish in a pond is with a rod and float.

Now, a word as to the best kind of dog to use for wild-duck shooting. An ordinary retriever, if she takes kindly to the water, is as good as could be desired, but this species of the canine tribe require most careful teaching. Nothing is more annoying than for a retriever to take the duck to the opposite bank of the river, drop it, and, on being called, swim back without it; yet I have seen them do it often. A day spent in the early part of the season by the river bank, shooting an occasional flapper, is excellent for teaching the young and inexperienced retriever; the water is warm, and the bird is not so likely to dive just as the dog reaches it. But on no account should a dog be made to take to the water by being thrown into it. Nothing gives them a keener or more lasting distaste for the business. He should also be prevented from getting into the habit of dropping his duck on reaching the bank for the purpose of shaking himself, as he may leave the bird in some inaccessible spot; he should, on the contrary, be trained to bring the bird up to his master's hand. The Newfoundland and water-spaniel are really the best dogs for this work, the former being a very strong swimmer. The latter requires to be taught to take no notice of water-rats, as these infest the river banks, and this species is very much inclined to hunt them. 
All water-dogs must be taught to range to hand, as their radius of vision is very small when they are in the water, and it is of material advantage to them if they can be guided and directed by the hand. It is very important, also, that all water-dogs should be very quiet, as the slightest bark or whine is fatal, and is sufficient to spoil a whole day's sport. The constant exposure of these dogs to cold and wet is liable to bring on rheumatic fever, especially if they are accustomed to sit most of the day before a roaring fire. The symptoms are : the dog will resent being touched, will snarl if you attempt to pat him, and will, as a rule, cower in a corner. The best cure is to give him a hot bath, dry him well before the fire, and then apply, by hard rubbing, a mixture of equal parts of spirit of turpentine, ammonia, and laudanum.

The directions which may assist the keeper in bringing up and shooting wild duck must, perforce, be of a general nature, as the method in each case will vary, depending largely on the conformation of the ground and the nature of the surroundings; but it should be observed that wild duck are very capable of looking after themselves, and that the keeper's chief difficulty lies in keeping the birds from straying, and his chief care in feeding them regularly when very young.

Note.-When the lie of the land is favourable, it is often possible to drive duck up a burn, from their feeding-ground, into an enclosure at a higher elevation. The guns being posted below, the birds are let out in twos and threes. The principle is very much the same as in the case of pheasant "showing."

P. J. M. 


\section{NOTES}


NOTES 


\title{
CHAPTER XV
}

\section{Notes on Wildfowling in Scotland}

\author{
By J. S. Henderson
}

I $\mathrm{T}$ is impossible to do justice to a subject so wide in an abridged treatise of this nature, and of necessity the writer must merely touch the fringe, but in so doing an endeavour will be made tobring forward those points which, strictly speaking, it is every gamekeeper's duty to be conversant with.

\section{Flighting}

This form of sport, which is annually becoming more popular, is, in the writer's opinion, before all other forms of shoulder gun-shooting. Every keeper, upon whose beat it is possible to indulge in flighting, should make it his duty to be thoroughly acquainted with the feedinggrounds, and the lines of flight in different winds, and so be able to place the guns to the best advantage. One of the chief points to be observed in flighting is to remain perfectly still and keep well out of sight. The keepers should see that at the various stands satisfactory cover is available. The gun should always face down wind, as it will be found that most duck beat their 
way up wind, and in stormy weather fly very close to the ground. If no shelter is available, the gun should try to have his back to a peat stack, peat bank, or any dark object, and if that is impossible his next best course is to kneel on the ground and remain perfectly still. Duck, when flying to the feeding-ground, shy much more easily on seeing a dog or man moving about than they do at the sound of the shots. In flighting, one requires to keep very much on the alert with both ears and eyes. In uncertain twilight the birds are often heard before they are seen. The birds should never be allowed to pass the guns, but should be taken whenever they come up. This applies especially to morning, evening, and moonlight flighting, when the light is uncertain, and the birds are within shot almost always as soon, and sometimes sooner, than they are within sight. Some advocate heavy shot for flighting, but the writer is of opinion that Nos. 5 and 6 are the most useful for this form of sport at all times, except during the day, when No. 4 in the right and No. 3 in the left barrel will be found the most effective. The reason why the smaller shot is preferred for morning, evening, and moonlight flighting is that a far shot is rarely available in the uncertain light, as the birds cannot be seen at a long distance. The flighter should get to his ground early and be comfortably settled ere the flight begins. He should be careful to take the warmest of clothing and the strongest of boots. On fine nights flighting need hardly be attempted. The best sport 
can be got on stormy nights and in frost. On a fine night the birds will fly too high, and will very probably not start for their feeding-ground till considerably after sundown, at which time it is impossible to see them except against a white cloud. The flighter should never be without a reliable dog, but he should not allow the dog to range for every bird that drops. Runners and birds which have dropped into the water should be retrieved at once, as also birds dropped in soft mud, as the latter are frequently so deeply embedded, that if not picked up at once, they can rarely be found. Except in day flighting, when one can mark his birds down, it is wise always to listen for the result of a passing shot, as frequently a fast bird will drop with a considerable thud far behind the gun. A flighter should always be most careful to see that his dog is thoroughly dried on returning home, as the cold and the effect of the seawater invariably, sooner or later, bring on rheumatism and deafness.

\section{Times of Flighting-Evening}

In the evening for about half an hour just at twilight, when the birds pass from their resting-ground at sea to their feeding-ground on some inland loch, burn, or estuary.

\section{Moonlight Flighting}

It is a mistaken idea that a clear, cloudless sky is best adapted for this form of shooting. A good moon 20 
and lots of white, fleecy clouds are by far the best conditions for showing up the birds to advantage. In autumn, about harvest-time, excellent moonlight shooting may be got when the birds are passing to feed on crop, stubble, or potato ground. Barley and potato fields are the favourite attractions, and the best situation for the gun in a field of grain will be at any "laid" spot near the centre of the field.

\section{Morning}

At dawn, for about the same space of time, the birds may be intercepted returning from their feedinggrounds to their resting-grounds for the day. This is rarely so satisfactory as evening flighting, as the birds do not conform to the same regular line of flight, and usually return to their resting-ground in large packs. Good sport, however, can sometimes be got by an alert "gun" posted by a creek or channel leading from the sea to the feeding-ground. The birds will nearly always follow this line of flight when returning at dawn to the sea.

\section{Day Flighting}

Very good day flighting may sometimes be got in rough weather when the birds are driven from the open sea or lochs and are making for more sheltered quarters. 


\section{Feeding}

As so much good sport can be got without the trouble of artificial feeding, the custom is not often followed, but those who care to try it will find that barley and potato refuse make the most appetising meals for wild duck, although oats, or, indeed, grain of any sort, will serve the purpose. If feeding is resorted to, the ground should be "fed" for three or four nights before a shot is fired, so as to allow the birds to become accustomed to it. Care should be taken not to place the food in hollows where the duck, if they alight unseen, cannot be shot. The most likely spot for natural feeding is just where a burn empties into a loch, and artificial feeding in the near neighbourhood may often be conducive to good results.

\section{The Best Season}

The best months for duck-flighting will usually be found to be November, December, and January, although the season varies a little in some districts. One of the chief interests and excitements in this class of sport is the variety of birds that may be killed before the "flighter" realises what he has "loosed off" at. Of course, such visitors (and they are frequent) as teal, widgeon, and plover herald their approach long ere one can give them the welcome "hail!" 


\section{Shore Shooting}

There is little to be said on this subject from a gamekeeper's point of view, but from a sportsman's aspect it is impossible to overestimate the advantages to be gained from this class of sport. One's knowledge for judging distance and pace can be brought to the highest standard by observing the results of the shots on the water, and varied indeed is the bag that may be got by a wary "shore shooter."

\section{Bog Shooting}

The chief point to observe here is to mark down the birds carefully. The guns should never loiter about hunting for dead birds, but should move steadily on from the moment they enter the bog, as duck, so soon as they become suspicious, will take to the wing if they observe the line standing or hunting about, whereas they will nearly always sit close enough, to give a reasonably near shot, if the guns keep steadily on. Some bogs afford better and surer sport by being driven. To execute a successful drive, the wind is the supreme factor to be reckoned with.

\section{Decoy Duck-Shooting}

Exceedingly good sport may be obtained, especially on a very stormy day, by placing a few decoy ducks within good range of a gun stationed near the bank of a sheltered bay or eddy. The decoy can also be 
used with success when ducks are flighting to crop or roots.

\section{Shooting Afloat}

When shooting from a small boat, especially with an 8-bore, the keeper must be most careful to keep the head of the boat well up to the waves. The recoil of an 8 -bore is sufficient to rock the boat and topple the gun into the water, unless the boat's head is kept well up. In approaching from the sea towards duck feeding ashore, always manœuvre towards them along the shore, and never by direct frontal attack.

\section{Punting}

This subject is a study in itself, and only a few practical points may be noted. The rest must be gleaned from experience. First beware of strong tides and southerly winds. A discreet punter will never leave the poling-ground with an uncertain wind, especially if it be from the south. When approaching a flock of duck, always give due heed to the sentinels that will be seen dotted here and there apart from the flock. Upon their conduct the punter should base his scheme of operations. An outlook should also be kept for black-backed gulls, as they are a frequent source of disturbance, and often mar what would have been ideal chances. Never attempt punting in rough weather, but watch and take advantage of the first lull after a storm. A punter should make a point of making as 
fast as he can for the scene of the shot to secure the wounded. This is especially essential if one be after ducks of the diving species, as they, though wounded, may give much trouble and often escape altogether. It will be found, however, that a wounded duck has considerable reluctance to go under water at first, and, if reached without loss of time, he can be finished off with a I 2-bore ere he makes up his mind to dive.

The vermin which are most disastrous to wildfowl and their eggs in Scotland are the grey crow and the black-backed gull. The larger species of hawks do a certain amount of damage, but they are becoming so few and far between, and wildfowl are so plentiful, that the sportsman is only too glad to accord to them ungrudgingly their toll of birds. Every effort should, however, be made to destroy the two arch-enemies which I have just mentioned. On some of the rocks in the Outer Hebrides where wildfowl nest in large numbers, one will readily see that it is impossible to magnify the damage and depredation caused by such vermin as the grey crow and black-backed gull. The shells of countless eggs, not to speak of the bones of young wildfowl, can be seen on almost every rock or prominence in the nesting quarters of the wildfowl.

\section{Wild Goose Shooting}

To attempt this class of sport with any degree of success, one must first procure a double 8-bore gun, although at times, with great luck, a considerable bag 
is made with a I 2 -bore and heavy shot. There are three recognised means whereby the sportsman may get to the windward of the wily goose-Stalking, Driving, and Flighting. I have stated these processes in their order of merit, as I think that every one who has had experience of wild-goose shooting will admit that stalking is by far the most interesting, although at the same time the most difficult, means of attack. Further, a successful stalk usually means a considerable slaughter. The wild goose, when feeding or at rest, always has his position guarded by alert sentries, and to stalk him with success one must approach him up wind and take advantage of every available piece of cover, having first carefully surveyed the ground with a telescope. The greylag goose is undoubtedly the most difficult to approach, and he usually adds to his security by taking up his position in the centre of a flat, where it is next to impossible to approach him under cover. Sometimes, however, he will allow a horse and cart to get within easy shooting distance of him, provided a circular manœuvre is adopted, and not a direct approach. Bernacle geese are much easier to stalk, and they will usually be found on a piece of good green pasture.

Driving.-There are various methods adopted with more or less success. One is by the usual process of taking cover. Another is by digging pits, both in the probable line of flight, which one should be able to gauge with considerable accuracy. Thereafter the geese should be driven towards the guns in as quiet a 
manner as possible without causing undue alarm. A method of driving usually successful is, where the geese are found on a small island, for the guns to take " post" in some narrow creek or channel, which the geese are known usually to take on leaving the feeding-ground. In such a course they will nearly always be got flying low and well within shot.

Flighting.-This is always an uncertain form of sport, and requires the exercise of much patience. A great deal of the matter bearing upon duck-flighting is applicable to geese-flighting, but the latter are best found, at least the grey lag and bernacle, flighting to corn and potato-fields. By an examination of the ground, the keeper will find ample indication as to where the guns should be placed, and if sufficient patience is exercised, success is practically certain to a more or less degree. The flighting hours correspond with those of duck.

Note.-As wildfowling is a sport practised only by a privileged few, it was thought inadvisable that it should be dealt with at any length. The reader is accordingly advised to seek further information from The Encyclopadia of Sport, from the volumes on Shooting in the Badminton Library, and from the works of Mr. J. G. Millais, Mr. H. G. Folkard, Mr. Abel Chapman, Mr. L. Upcott Gill, Mr. Horace Cox, and Colonel Hawker. Those who are interested in the question of shooting with swivel and other forms of guns will find full information in the works of many of these writers. 
NOTES 


\section{NOTES}




\section{CHAPTER XVI}

\section{Miscellaneous Sport}

\section{Plover}

There is very little to be said with regard to the keeper's duties as they affect plover. He may be called upon to direct the guns how to proceed. There are no very definite laws to be laid down. Of course they should no more be approached in an open field than partridges should be, for plover are even more wary than the brown bird. They should be approached by the circular method described in the chapter on the Partridge. The best chances, however, are obtained by attempting to drive them down wind, the drivers approaching the birds in a circle, slowly and noiselessly.

The following is recommended by the Fowler in Ireland: "Another method of getting within range of plover congregated in a field is to tie a dog to a short stick and peg it down into the ground, leaving the animal a tether of five or six yards. Secure him a couple of hundred yards away from the 'stand ' to windward, and every bird's eye will be turned in his direction as he moves or struggles. You may then steal up to them on 
their other flank against the wind, and will always get within fair, often easy, shot."

\section{Pigeons}

Pigeon-shooting from traps hardly comes within the scope of a keeper's duties, but a few remarks may be made as to the killing of wild wood-pigeons. A few head may be obtained by simply beating a wood. When this is done, great care must be taken that the guns are placed a considerable time before the beaters enter the wood, as on the first crackle of a broken stick the pigeons will begin to leave the covert. The keeper should take care to note the customary flight of the birds, and place the guns accordingly. Pigeons generally fly from covert to covert, and as a rule take the shortest line to get out of a wood. The question of wind, of course, is important. In leaving covert pigeons seldom fly against the wind, but almost invariably do so when returning to it. But to obtain any large bag of pigeons in a short space of time, decoys must be used. These may either be stuffed pigeons or birds just shot. In the former cases, the decoys should have copper wire passing from within the bodies of the birds down the legs, with, say, some sixteen inches projecting from each foot. In the latter cases, thepresent writers have long found the following method efficacious: Pieces of wire-netting are cut so as to fix the fresh-killed birds with their wings clasped to the sides, and their heads erect, on to branches of trees. 
But, whatever the form of decoy, it must always be placed with its head facing the wind, and the gun or guns should stand some fifty yards away, facing it. "It will be found useful," says Lord Walsingham, "to be prepared beforehand with several short sticks, pointed at both ends, and when ten or twelve birds are down, to gather them quickly and set them up on open spaces beneath the trees as assistant decoys. With wings closed to their sides, resting on their breast bones, they can be fixed with heads erect or craning forward as if in search of food, by passing the upper end of the stick through the lower portion of the beak, the opposite end being stuck into the ground beneath the crop of the bird."

Great care should be taken by the keeper in selecting the cover for the "guns," and he should also warn the latter as to the necessity of their clothing being as near as possible akin to the colour of the cover in which they are standing.

\section{Capercailzie}

In placing the guns for capercailzie-driving, knowledge of the usual flight of the birds is of value. In our experience capercailzie generally come out of covert and then take a wide sweep round and close to it and then fly in again. They seldom fly out into the open. Guns should be placed quite near the covert. In preserving the stock, care must be taken, as in all other cases, to eliminate vermin. 


\section{Woodcock}

The movements of these migratory birds are very uncertain. They come to-day and are gone to-morrow, and nothing can be done to increase or encourage them. Soft feeding-ground is, however, a great attraction. A certain number remain in this country and breed, but the most of them come in with the first severe weather, when a thaw comes they move away, and they seldom return, but it has been noticed that while they cannot be found in the coverts they are very often got on the moors and open ground, not having left the countryside, as some supposed. In the event of woodcock not being in coverts, it is well worth trying the open moor for them, especially when the moor lies to the sun. Whenever the cock are in, the keeper should advise his master, and as their stay is very uncertain, get at them at once.

The keeper will have difficulty in knowing whether he has woodcock in his coverts or not, and having discovered them, he cannot tell how long they will remain. He can, however, be certain of the fact that woodcock, as a rule, during the time they remain on the ground, are loath to leave any favourite shelter they have chosen, and will even fly back to the place they have been flushed from in a beat. Accordingly, it is often wise to go over the same ground a second time. Markers outside the coverts will be able to give important information as to whether cock have left a covert or not, although it is often very difficult to accurately mark the place where 
a bird has alighted. Woodcock that have been marked down should be followed up at once, as they have a habit of rapidly changing their quarters when they know that guns are about. They often fly into the hedges or under the dykes at the outside of the covert. It is very desirable that these should be well beaten. The covert ought to be beaten thoroughly, and if the beat is especially for cock, the holly bushes and laurels should be well shaken. The best days to shoot woodcock are after clear moonlight nights, or days on which the sun is not too bright. Then the keeper may be certain that the woodcock, who is entirely (except under very pressing circumstances) a night feeder, has fed well and that he will lie well, being inclined to be sleepy and lazy. Cock, of course, vary their habitat according to the weather. After a frost they will be found where water can best be obtained. Accordingly the ditches and drains in the covert should be carefully explored.

The first days after a severe frost are the best for single or two or three guns. All likely places should be worked first, then the ground the birds have flown to, and the guns should finally return to the beat they first worked, but not sooner than two or three hours after they first shot over it.

When the birds are lying well - that is, after a bright night in which they have fed amply -it is better to walk them up ; if they are lying badly, that is, after a night in which they have not fed well, it is better to have the birds beaten to the guns. In such weather, an outside 
gun walking with the beaters, or a little in advance of them, is of great importance, and he should be warned to keep a sharp look-out in passing any openings in the covert.

In looking for cock in the open, it must be remembered that they generally feed on the lee side of a hill, and may be found where they feed. It is better to remember this rule than to trouble one's memory by north, south, east, or west. When there is no wind, they choose the brightest or sunniest side.

\section{Roe-Shooting}

In shooting roe-deer by driving, the main point to be remembered by the keepers is the tendency for the roe to break back through the line of beaters, and therefore he should advise, if necessary, that some of the guns should walk with the beaters. The other guns should be kept absolutely out of sight.

\section{Hares}

In considering how to maintain a good stock of brown hares, it is necessary for the keeper to remember that they require a lot of cover.

In driving hares, the drive should be down wind, there should be plenty of flanks, and the beaters should advance slowly and quietly.

For the improvement of stock, a few bucks and does should be turned down yearly. They are easily obtain- 
able from certain game farms at a moderate price. It is better, however, to secure them from a more intimate source. Owing to the size of the hare, which makes it an easy mark for the gun, the stock needs constantly renewing, or it will soon disappear altogether. A strict limit should be fixed every season on the number of hares to be shot.

\section{Poaching Hares}

Hare-poaching is generally carried out by driving the hares towards a gate, on the outside of which a net is fastened. On this account the bottom bars of gates should be so close together that a hare cannot bolt through.

\section{Snipe}

The snipe are migratory birds, but increasing numbers are year by year nesting in this country. They rather upset one's usual methods of shooting, but make good sporting shots. Where the ground is of little value, it should be remembered that, while draining in many cases is necessary, a little wet land should be left on a shoot here and there for the home of snipe and wild duck. Why some ground should be more suitable than others for snipe it is hard to determine, but it is more than likely that the feeding is the attraction, and that rich, soft land with lots of worms is the source of attraction and the most likely haunt of the woodcock and snipe.

The observant keeper should have a very definite 2 I 
idea as to the haunts of the snipe on the ground under his charge, and he should remember the important fact that snipe are very conservative in their habits, and that once they have selected a habitat there will they always be found. From the many facts known as to the habits, habitats, and shooting of snipe, we select the following as worthy of the memory of the keeper:-

(I) Snipe are markedly affected by the moon. Choose a day for shooting after a clear night. Then they will have fed well, and will lie well to the guns. For, like woodcock, snipe feed chiefly at night time, but after dark nights snipe feed during the day, and are very much on the alert.

(2) The best time to shoot snipe is during the thaw after a frost. During this time they get a plentiful supply of worms, which always come very near to the surface of the earth after frost.

(3) Snipe lie best in muggy weather, with a gentle breeze and a barometer which shows a tendency to fall, and after a moonlight night.

(4) Snipe lie worst in bright, fresh weather, with a high breeze, and after a dark, cloudy night.

(5) In the generality of cases, in finding the birds, the guns should walk down wind-

(a) In a thaw-when the birds will be lying well ; 
(b) When the birds are lying badly during a strong wind.

On the other hand, the guns should walk up roind-

(a) During a sharp frost, when the birds will be lying badly ;

(b) When there is but a light breeze (but not during a thaw) after a dark night ;

(c) In approaching a bird for the second time after flushing.

(6) The best hours to shoot snipe are those immediately following daybreak, and the hours just before dark.

(7) Snipe-shooting should not commence on Ist August, as commonly practised. The end of September is the earliest time they are likely to be found in good condition.

(8) Better shooting is obtained in big grass fields soaked with water, or in bogs that have only shallow pools, than in large flooded bogs and extensive marshes. In the latter case a single shot may cause a whole flock to rise "in wisps," and thus offer poor sport. In these cases it is perhaps better to drive the birds. If suitable arrangements can be made, a rope may be drawn across the bog or "moss." In those cases where mallard and teal are also present, capital sport can be obtained with good guns. 
(9) It is wise to remember that, after being shot at, snipe may fly or be blown long distances and then fall dead.

(10) The best dogs for snipe-shooting are Irish water spaniels and red Irish setters, the latter being used for shooting over bogs or large marshes, and the former for smaller and drained marshes. 
NOTES 
NOTES 


\section{CHAPTER XVII}

\section{Diseases of Game}

GrouseDisease.-Thereisnot much that a keeper can do to directly attack disease in grouse, but as prevention is better than cure, he will take care that the directions given in Chapter IX. for the improvement of ground and stock are carefully carried out. We may in this place recall the principal causes that are known to be favourable to disease in grouse :-

(I) The presence on the moor of " peppered " birds.

(2) Want of draining; much old and rank heather.

(3) The presence of decayed or decaying matter, such as the carcases of sheep, grouse, etc.

(4) Inefficient water supply in dry seasons.

(5) Absence of grit and lime.

(6) Interbreeding and overstocking.

These conditions may not actually be the direct cause of disease, but they are recognised predisposing causes, and such are always taken into account in the study of disease.

When a dead bird is found, the keeper should endeavour at once to discover the cause of death. If he is satisfied that it has been killed by wire fencing or tele- 
graph wires, the fact should serve to indicate that there are remedies for such possible sources of disaster. If no such cause is to be discovered, he should cut the bird open and look for disease. All grouse found dead on the moor should be burnt.

The Grouse Commission is still sitting, and will next year publish a full report, which will make interesting reading ; up till now nothing definite has been discovered of the predisposing cause of grouse disease.

In a previous chapter we mentioned that Dr.Shipley, F.R.S., who is investigating the subject, has not yet been able to find the host of the tapeworm. The theories are many, but before any are accepted abundant proof will require to be brought forward. Some keepers think that the dog will be found to be the cause of the tapeworm in grouse. Dr. Shipley is giving mites and ticks careful attention. In Ross-shire ticks are numerous in certain woods, and keepers say they kill a large number of black game, but the tick has never been found in the crop of the grouse. He says, for instance, that the tapeworms which live in the alimentary canal of the grouse pass their younger or larval stages in the body of some lower animal. This lower animal-presumably an insect, or mollusc, or spider - must be eaten by a grouse, and the larval tapeworm is set free before the latter can grow up into the adult tapeworm which we find in the intestine of the grouse. In searching for this second host, it was natural to begin with the ectoparasites, which one would imagine 
were being continually snapped up by the bird. We have, however, up to now completely failed to find any cestoid larvæ in the grouse-fly or in the numerous "biting lice" which abound on the skin and amongst the feathers of the grouse; and what is still more significant and still more remarkable, we have, in the hundreds of crop contents which we have examined, never found one of these insects in the grouse's food.

Dr. Shipley also describes the different parasites, commencing with the grouse-lice, which does so much harm to the grouse in the bad years when they are feeble and unhealthy; this lice is the commonest of the insects which infest the skin of the grouse, and appears to some extent in inverse measure to their health. Careful search will discover but two or three on a healthy grouse, but on a "piner" hundreds may be met with. No doubt we will yet discover the host of the tapeworm or the cause of the grouse disease. I made the following observation two years ago, on a moor, where attention had been given to burning, draining, vermin-killing, etc. etc., with the hopes of bringing the bag up to a given limit : a larger stock of grouse was left in 1907 , and one hundred and fifty brace that might have been shot were spared in the hopes of a record year in 1908. One fact, however, was omitted in the calculations. The season had been a very bad heather year, so that there was no feeding during the winter for a large stock of grouse, and in consequence the grouse got into poor condition, pined, and suffered much 
from disease. The result was that instead of being a record year, as was expected, the season of 1908 was a complete failure, with the result that no shooting took place at all. Next season new blood was introduced from Yorkshire, and the birds are again increasing in number and healthy. There can be no doubt that land or water will only support a certain amount of life which is regulated according to the food. Overstock and you bring disease and death. How often do we forget that Nature's laws cannot be set at naught with impunity?

Pheasant Disease.-Overcrowding and interbreeding are the main causes of disease in pheasants. When disease breaks out, all affected birds should be killed, and the rest of the stock moved to fresh ground, and a careful examination made into the dietary and hygienic surroundings of the birds. The bodies of all pheasants killed by disease or killed on account of disease should be burned. Disease is often caught from the domestic fowls. The condition of the latter should be carefully inquired into, and the same procedure taken with the affected fowls as with the affected pheasants. It is wise, as soon as disease shows itself, to give lime freely to all the birds. Lime should constitute an essential part of the food of pheasants and of the ground upon which they live.

When worms appear, isolation of the affected birds becomes imperative, and the removal of the unaffected birds to healthier soil. The affected pheasants in these 
cases may be sprinkled with a weak solution of salicylic acid or salicylate of soda, and a little of the solution should be added to the drinking water.

Mr. Shipley says: "In individual cases the worms may be removed by dipping a feather stripped of its barbules except at the tip, into a mixture of one part of oil of turpentine and two of olive oil, or into oil of cloves, and then inserting it into the trachea; on its withdrawal it will probably bring with it the worms. The operation requires a little care, or asphyxiation may result. Garlic mixed into the food and rue mixed with the water have also proved successful."

Putting birds in boxes containing two parts, by weight, of powdered chalk to one of camphor is recommended by some authorities, while Mr. Tegetmeier recommends that the birds should be fumigated by volatilised carbolic acid. This can be done by putting the affected birds in a box in which a hot brick has been placed and pouring a solution of carbolic acid on the brick.

Gapes.-Lime dust sprinkled in the coops in the morning is useful in this disease. At a later stage garlic should be given with the food, once a day.

Cramp.-Change of soil is the treatment recommended here.

Ophthalmia and other Eye Affections.-The birds should be removed from their present rearing-ground.

Diarrhoea.-A little starch mixed with food soon corrects this. Food should also be changed. 
Scurfy Legs. - The coops should be thoroughly cleaned and whitewashed, and the legs of the affected birds well soaked in hot water, the scales peeled off, and the legs then washed with some antiseptic soap. All affected fowls should be removed, and all affected pheasants isolated.

Partridges.-The remarks made above in regard to overcrowding, interbreeding, change of ground and food, cleanliness, and the burning of all dead birds, apply equally to partridges as to pheasants. What has been said about supplying partridges with drinking fountains in very dry weather must be remembered in considering the question of gapes. Mr. Horace Hutchinson practically cured his estate at Newmarket of this disease by putting down numerous drinking fountains the moment dry weather set in after hatching time.

Rabbits. - The constant change of blood, attention to the feeding capacities of the ground, and the avoidance of turnips as a food are the best preventives of disease. If disease has spread to any large extent, the whole stock should be killed off. This applies also to partridges and to pheasants. The ground should also be thoroughly dressed with salt and lime. 


\section{CHAPTER XVIII}

\section{Loaders and Gun Cleaning}

It is only by practice that the loader can learn to come into sympathetic practice with the shooter. The harmony between the two must be complete, if success is to be looked for, a harmony so perfect as to make the practice of exchanging guns almost as automatic as a machine. But the first point for the loader to remember, and never to forget, is that the gun is an enemy to life, and that no weapon, whether it be I 2 -bore gun, fowlingpiece, rifle, air-gun, or penny pistol, should ever be directed, either loaded or unloaded, with the barrels pointing at any living thing, except for the purpose of killing. The muzzle of a gun should always be inclined to the earth or to the sky, clear from everything whose life is of value. If these principles are borne into the intelligence, they will assist the loader in carrying out his duties with success. In loading he must remember to keep the point of the barrels clear of every one, "to depress the muzzle while turning away from the shooter, and in shutting the gun always to raise the stock to the barrels, and not the barrels to the stock, so that if by any accident the charge explodes, it can only make a 
hole in the ground." The gun should never be closed, if loaded, while the loader is turned towards the shooter. Guns should never be loaded until the shooter takes his place at his stand, and should always be unloaded as soon as the drive is over.

It is highly desirable that a little rehearsal should take place between the shooter and the loader, if they are strangers to each other at the game. When the loader is the shooter's own servant, five or ten minutes' practice in the gunroom on "off" days should be indulged in, and also now and again during the summer. This will save a lot of bother, wasteful movements, and irritation when "the trouble" begins. The loader must always be keen and on the look-out, not at the birds, but at the man who is using the guns. He is not intended to spot the birds and call "left," "right," or "over"; he is only there to see that his shooter gets a loaded gun with the least degree of trouble. $\mathrm{He}$ must be on the alert to get out of the way, as the shooter varies his position so as to get a suitable angle to loose on his bird. The position varies most in partridgedriving, at which practice the capacity of the loader will be tried to the utmost. Coolness is a most valuable quality, and this is demanded most when rapidity of loading is an essential. All guns should be loaded as if they were wanted quickly, even though the loader is aware that there is no particular hurry. He errs then only on the safe side, and the practice of quick loading at all times will perfect his art in general. To 
assist in the perfection of his practice, the loader should rehearse the loading and unloading of guns-at other times, of course, than shooting ones.

The position of the loader is varied by the preference of the shooter and the game to be shot. Some shooters like their loaders immediately behind them, some on the right and others on the left. On this point Lord Suffolk and Mr. Craven write: "When rocketing pheasants are the sole objects, the loader may stand right half-forward without in the least interfering with his master, who, indeed, will be rather helped than hindered; but if hares and rabbits are also coming out of covert, the man must be well half-back. In grousedriving a position on the immediate right is obviously to be recommended, for thus placed the loader will only interfere with a shot which would pepper the occupant of the adjoining butt on that side. For partridgedriving over high fences or belts, the rule is the same as with tall pheasants."

In changing guns the shooter throws up the barrel and grasps the gun by the neck and turns slightly to the loader, who takes it with his left hand and passes the second loaded gun smartly forward with his right. While holding the unused loaded gun, it should be held just below the triggers with the right hand, and the right arm should be leant slightly across the chest so as to rest the barrels on the left arm. The barrels will then be pointing in the air to the left and behind. 
Hints to Loaders.

(a) The loader should never touch the "safe" slide, and when loading should turn his back to the gun. After loading, in closing the breech, raise the butt and not the barrels. This is most essential to the safety of the gun and the loader. Of course it is understood the point of the weapon will be pointing to the ground when loading.

(b) The loader should never talk, and should never smoke on duty. It is considered very bad manners and can onlybeexcused on the score of ignorance.

(c) The loader in wet weather should protect the mechanism part of the gun as much as possible, and should wipe it from time to time with an oiled rag.

(d) Should any difficulty be experienced in working the lever, the gun should be carefully examined for dirt or any remains of cartridge paper.

(e) Damp cartridges should never be used.

$(f)$ If mud or sand or other foreign substances get into the barrels, they should be well run through with the lead cylinder and the pocket cleaner.

$(g)$ Always inspect the gun thoroughly after any accident of the nature of tripping or of drop- 
ping the gun. No gun that has the barrels badly indented should be used.

If a third gun be used, it should be held by a keeper or a second loader, who stands behind the shooter and first loader. It is this man who may keep his eyes on the birds, but never the loader.

\section{Cleaning of Guns and Rifles}

In addition to the regular cleaning of the guns at the end of the day's sport, there is something to be said for cleaning them at intervals in the shooting. When there is much heavy firing, as in a big grouse or partridge drive, or a big covert shoot, it is in every way desirable that the barrels should be at least "run through" some time during the day. Clean barrels minimise any tendency to "rebound," or create it where it does not naturally exist. The procedure to be recommended in cleaning a gun is the following :-

(I) Take the gun to pieces, and place the barrels on a cloth.

(2) First clean the barrels with hot water, and run over and through with tow.

(3) Put finest paraffin or Rangoon oil on clean tow at the end of a rod, and run the barrels well through.

(4) Run through the barrels again with clean soft tow.

(5) Coat the inside and outside of the barrels with vaseline. 
(6) Remove all grease from barrels and chambers before the gun be used.

In addition, the breech action should be carefully inspected and wiped over with vaseline. The ribs and the sides of the ejector part should be gone over with a soft mop dipped in the same. A similar practice is to be followed in the cleaning of a rifle. With the introduction of cordite and other new powders, it is often found necessary, especially in the cleaning of rifles, to use some special preparation like Nitroclene, or Webley's 303, or Semper Idem.

When a gun or rifle is put away and not inspected daily, the barrels should be covered with a mixture of paraffin and neatsfoot, and the inside of the barrels rubbed with the same mixture.

If there are signs of lead, this may be removed by corking the bore at one end and filling it with spirits of turpentine.

If a gun or rifle be very rusty, boiling water and then paraffin may be used, care being taken to remove the paraffin before the weapon is put away.

In addition to what has been said, the following points may be noted :- (a) No keeper or loader should interfere with springs, screws, etc. If the gun or rifle goes out of order, he should inform the owner as to the condition, and he will, unless he is himself an experienced mechanic, which is unlikely, send his weapon to the maker; (b) gun locks should never be cleaned with thick oil, as this is apt to collect dirt and become 
sticky, and so cause clogging; $(c)$ no paraffin should be left wet on a gun, as it evaporates rapidly and causes rust. Refined paraffin should be used. Instead of paraffin, chronometer oil or refined neatsfoot has been recommended. Care must be taken never to lay a gun flat on the ground ; it should always lean against something solid and firm-muzzle upwards.

Every gunroom should have a card, hung or pasted up, giving directions for the cleaning and the keeping of guns and rifles. These cards should be supplied by the gunmaker, and should have the following points in large print :-

(I) All guns to be thoroughly wiped immediately the shooting is over. (If the shooting is some distance away from the gunroom they should be wiped in the open.)

(2) All guns and rifles to be thoroughly cleaned and freed from rust and lead as soon as possible after they are brought to the gunroom.

(3) Wet guns should not be put in a warm place, as this is apt to cause swelling and steaming and rusting of locks.

(4) All injuries or inefficient working of any part of guns or rifles to be reported at once to the owners of the same.

(5) Great care should be taken that when a gun or rifle is in the possession of keeper or loader, it is not injured by falling or knocking against anything that will damage it in any way. 
(6) If by any carelessness-for instance, by loading with a cartridge that has fallen on the ground -sand or grit gets into the breech or lock, special care must be taken in cleaning, in order not to scratch the mechanism.

Ammunition.

Note.-Cartridges are private property, as much as a man's horse, dog, gun, or money. 
NOTES 
NOTES 


\section{CHAP TER XIX}

\section{The Gamekeeper as a Fishing Gillie}

By P. D. Malloch

W IтH the space at my disposal it will be impossible for me to exhaust the subject or do little more than mention the principal duties of the fishing gillie.

River Salmon-Fishing from the Bank.-The first duty of the gillie is to see that the river is properly protected from poachers. Should there be no net shots on the beat, the places which could be netted ought to be protected; this can usually be done, and at little expense, by putting large boulders, anchors, or stakes in the river. When pools are thus protected, sweep netting, as a rule, will be prevented, and trammel netting also, in part. The latter method of netting is, however, difficult to put a stop to.

A careful look-out should be kept for any signs of trammel netting. If it be suspected that this method of poaching is being carried on from a boat, the gillie should observe if any scales of fish have been left in the boat or on the bank.

A sharp look-out should be kept in the morning to 
see that the pools are not fished before the owner comes down to the water. There is nothing more annoying to the angler than to find, from marks on the sand or grass, that the pools have already been fished by a poacher an hour or two before.

If the gillie is unable to keep watch in the morning, he should stretch a few threads across the paths where the poachers are likely to pass; he will at once be able to detect if any one has been on the paths since he was last there. Should he find the threads broken he can set a watch for the intruders.

The gillie should have a knowledge of the time when the fish begin to run up, where and when they begin to rest at different seasons; the effects of snow water, frost, and fresh water on their running; and the time the river will take in coming into ply after a flood, so that he can advise the angler when his water is ready to be fished.

The temperature of the water should be taken daily. Much can be learned by doing this. When a daily record of the temperature of the water is kept, the gillie will have some idea what size of fly to recommend, and whether bait-fishing should be resorted to or not.

A gillie who has an interest in his work will take every opportunity of watching the river, the fish, and the direction of the wind. He should also have a knowledge of all the pools and streams - their depth, the lie of the fish, and the state of the river which suits the fish 


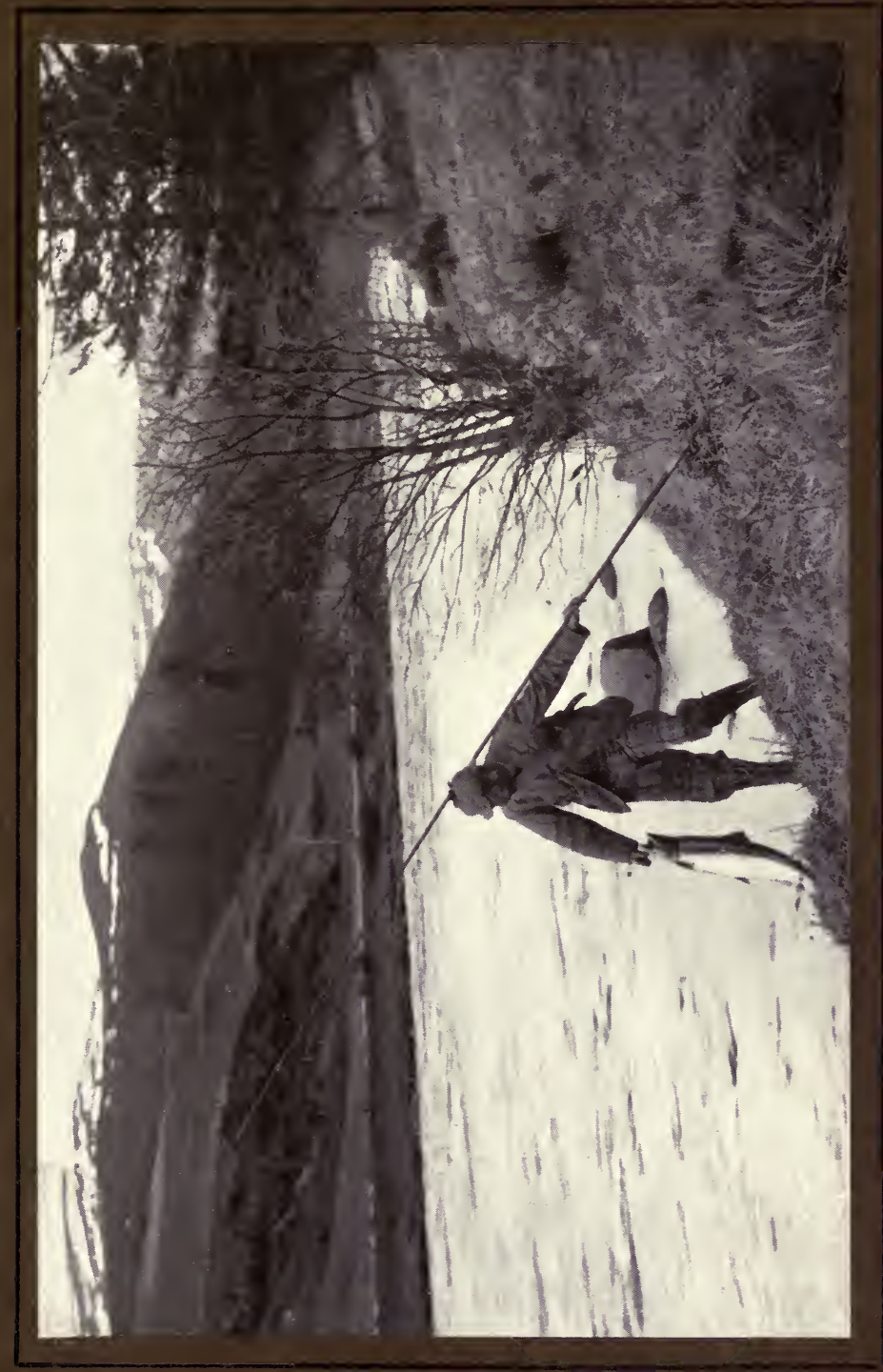

$\frac{x}{3}$
$\frac{3}{2}$
$\frac{2}{2}$
$\frac{2}{n}$
$\frac{1}{n}$ 
best. This knowledge is most important, and by the possession of it much of the angler's time can be saved. To acquire this knowledge requires years of careful observation on the part of the gillie, although much valuable information may be got from older fishermen who know the beats.

The gillie should discover the effect of the sun upon the pools, the direction of the wind that catches certain of them, and the best side from which the pool should be fished.

When the river is low and out of ply the whole beat should be carefully inspected, and all dangerous roots and sticks, on which a fish might foul, should be removed.

The croys, if any, should be repaired, the paths along the banks put in order, and any parts of the banks of pools looked to after a flood. As a rule, far too little attention is given to these questions, with the result that many fine pools become worthless. The clever gillie does not need to be told this; he is always thinking how he can improve his fishing by erecting a croy at one point and another one on the opposite side, so as to contract a wide part into a narrow part, and thus form new pools and improve others, or by rolling a stone into a pool to make a rest for the fish. This week (2oth October) I killed three salmon behind a stone which a keeper rolled into a pool on the river Earn two years ago, where no fish had rested before. 
Now I shall suppose that the gillie or keeper has instructions to telegraph to his employer, or angler for the time being, as the case may be, whether he should come or not on the opening day. His employer has never fished the water, or seen the keeper before. The river is in order, and plenty of fish are showing, and the keeper wires for his employer to come down.

If arrangements have not been made as to the terms on which the gillie is engaged, the angler ought to make it his first duty on arriving at his beat to rectify the omission. The wages should be fixed at so much per week, to be paid fortnightly or monthly, as may be arranged. When lunch is not provided, a money payment is usually given instead. The arrangements come to should be perfectly clear and definite, so as to save any possible annoyance to either party afterwards.

Before going to the river, the gillie should see the tackle, rods, reels, lines, flies, casts, and baits which have been provided for the fishing; he will then be able to advise as to the best length of rod, the most suitable reel and line, cast, line, and fly in the stock, and what will be sufficient to take out for the day. He should not fail to see that there is a gaff, a suitable landingnet, a bag to carry the fish, and a basket or bag for the luncheon. It is the gillie's duty to see that nothing is left behind. He should run all the items over in his mind before starting for the river. Perhaps by repeat- 
ing the following well-known rhyme he might assist the memory :-

"Rods, reels, baskets,

Hooks, worms, flaskets." 1

With regard to the last-mentioned article, the gillie would do well to see that it contained no more spirits than he could safely carry home. The gillie or keeper who takes a drop more than he should do lowers himself more in the estimation of his employer than by anything else I know of.

Having got to the river, the first thing to do is to put up the rod, and then see that the reel fits tight, and that the line is put through all the rings without it being twisted round the rod. The gut cast should be carefully soaked, and then fitted neatly to the main line before the fly is attached. The cast and fly should then be tested, and the rod handed to the angler, who may then begin fishing.

The following remarks might be overheard at this time, if one were within earshot of a well-trained gillie : "Cast a short line to begin with, but when you get down to that ripple, let out a few more yards; that is

1 To modernise this old rhyme and make it so complete that it will include gaff, baton, landing-nets, fly-books and cases, waterproofs and luncheon, we suggest the following as being fairly comprehensive :-

"Rods, reels, and hooks,

Nets, bait, and baskets,

Gaff, baton, books,

Coats, lunch, and flaskets.' 
where they usually come. From that part fish carefully down for another twenty yards; we will then go on to the next pool."

The angler begins to cast, and during the first halfdozen casts there are anxious moments for the gillie. $\mathrm{He}$ knows by that time whether his employer is an experienced angler or not. He sees his employer is casting straight across, and politely requests him to "Cast a little straighter down, sir."

After a few more casts, something pulls down the rod and the line begins to run out. After a run or two, the fish shows itself to be a kelt. "Do not be particular with him, sir," you remark.

The fish is brought bankwards as quickly as possible. Instead of the gaff, the net is put under it and pulled ashore. The hook is carefully extracted, and the fish returned to the river with as much care as possible. On no account should the gaff be used. The fly is examined to see that the tinsel has not been torn by the kelt's long teeth.

Another start is made at the same place; there is another pull, and the reel sings out again. A livelier fish this time, and he jumps into the air. "A spring fish, sir ; be more careful." After a little time the fish nears the shore. The gillie remains quiet, gaff, instead of net, in hand this time. Several times the fish comes within a few feet of the gaff, and as often rushes out into the stream again. The next time it comes within reach of the gillie, who puts the gaff quietly over the fish's 
back and pulls. The moment he does this he stands erect, with the end of the gaff-handle pointing upwards, and the fish hanging on the gaff hook. He then walks quietly to a safe place, seizes the fish by the tail, takes out the gaff, lays the fish on the ground, and gives it three or four sharp knocks with his little baton; extracts the fly, weighs the fish, carefully washes it, and puts it away in the bag provided for the purpose. A note of the weight is then recorded in his book. The whole of this procedure should not take more than three minutes, at the end of which time the angler is again ready to begin.

He fishes down the pool, sees nothing more; walks on to the next pool, and is directed in the same way as at the last. This pool is fished down without a rise, and the gillie begins to think the fly is either too large or too small, or is not of the right kind; and advises that a more sombre-coloured fly two sizes smaller should be put on and the pool fished over again. This is done, with the result that other two spring fish are added to the bag. The angler by this time sees that the gillie understands his work, and is accordingly willing to place every confidence in him. The two become friends, and the fishing turns out a success, being a source of pleasure to the angler, and of profit to the gillie.

When the fishing is over the rod is taken down, everything is carefully packed up and taken home. The gillie unwinds the wet portion of the line on to a line-drier, so that it may be thoroughly dried and ready 
for use the next day. The flies which have been used' should be dried before being put away. The waders should be turned inside out and hung up to dry. The wading-boots and worsted stockings should also be thoroughly dried. Sometimes before looking after these details the fish have to be carefully packed, labelled, and sent away.

Before leaving, the time is arranged for starting next day. Day after day passes in the same pleasant way until the season is over.

What a contrast to the gillie who does not understand his work! He goes out in the morning with his flasket filled to the top. When he gets to the riverside he finds he has forgotten the reel, and has to walk or run back a couple of miles to secure it, leaving the angler on the river bank wasting the best hour of the day. The gillie knows that a certain pool is a good one, but does not know the exact spot where the fish rise. He tells the angler to begin at the top and fish to the bottom. Instead of fishing only fifteen yards, he fishes three times that distance, when there is no real chance of hooking a fish.

When a fish is hooked, this inexperienced gillie tells the angler in a rough sort of way to hold up his rod, or to hold it, as the case may be, down. By the time the fish does come to land, he rushes up and down the side of the river frightening it, and takes double the time he ought to to bring it to the gaff. When a chance of gaffing is offered him, he is sure to miss it. 
This stamp of gillie, to put it mildly, causes much annoyance and displeasure to the angler.

River. Salmon-Fishing from a Boat.-In river salmon-fishing from a boat the gillie's duty is to see that before the anglers come out in the morning the boat is brought up to its proper place, the water baled out, and everything made clean and tidy, so that when the anglers appear no time is lost before starting. There should always be suitable landing-places for the boat whatever the state of the river. Where the boat has to be pulled up on to the riverside, the bushes should be cut every year and the footpaths kept in order.

The boat should be taken quietly to the side of the stream, sufficiently near for the angler to command it. The quieter the boat is worked the better the sport will be; a boat always disturbs the water, although many gillies think the contrary. I have many times proved this. After a good angler has fished over the water in a boat, I have often quietly waded in and killed many fish; so, Mr. Gillie, never go splashing over the water, and on no account cross over a good pool if it can be avoided. The boat should be held as steady as possible. After every cast it should be let down a yard, and no part of a good stream should be missed.

If the stream is so broad that the angler cannot command it from one side, both sides can be fished; but if too wide to be fished from both sides the boat should be worked quietly first out and then in. When a rise 
is got the boat should be pulled up a yard so that the fish may get another chance of taking the fly: this is easier said than done, as it is difficult to keep a boat in the same place in a stream. A sharp look-out should be kept for some bush, tree, or stone that may be on the bank, and which may serve as a guide to keep the boat in the exact spot required. When a fish is hooked, never be in too great a hurry to get to the shore. As a rule the fish will follow the boat. The angler will find that the best way to get the fish out of the stream is to hold his rod steady and not to wind in the reel. Should a fish make a run, the boat should be stopped until it settles down, then the gillie should pull towards the shore, selecting a spot where the water is deepest as the best place to land a fish. If possible, try to get the fish up into the fished water, so that it will not disturb the unfished water. When the shore is reached, do not bump against it. If you do so, there is a danger of your upsetting the angler. When sufficient line has been taken in and the fish is under command, the seat should be taken away and the angler allowed to land. He should be told to keep well away from the bank, as he will thereby run less risk of losing the fish. The fish can be either worked towards the stern of the boat and gaffed then, or worked towards the land and gaffed from the shore. The gaff, by the bye, should be kept as sharp as a needle.

An expert will usually take the first chance of gaffing the fish, as it comes within reach many times before it 
is played out. Some gaff the fish under, others over the back, while others again gaff the fish in whatever way opportunity presents. When gaffing over the back, the gaff should be reached out, laid quietly over the back fin, and pulled. The moment the fish is gaffed the handle should be held perpendicular and the fish lifted into the boat. Before removing the gaff the fish should get three or four sharp knocks on the head with the baton. The gaff can then be removed, the hook extracted, the fish weighed, and a note taken of the weight, then washed and laid in the bow of the boat. Any blood in the latter should be carefully wiped up. All this should not take more than three minutes. A fish should never be gaffed near the head, as there is the risk of gaffing the line instead of the fish.

In gaffing, the gillie should try to get within reach of a fish as quickly as possible, but should never be in a hurry in striking. When the right moment arrives he must do it quietly and deliberately, not by raking at the fish three or four times in quick succession. If he does so he will be sure to make a mistake. The number of fish which are lost at the gaffing is enormous. I usually tell a man who has never used a gaff before to put it over the fish's back and pull, and he usually does it all right. The great thing is to keep perfectly cool.

Fish which are caught with minnow or prawn should always be gaffed. If landing-nets are used, the hooks usually stick in the meshes and the weight of the fish 23 
breaks them. The fish should always be killed before being laid down in the boat, or the hooks may stick in the bottom of the boat and get broken. Grilse of small size are difficult to gaff; they are much easier netted. Salmon up to $40 \mathrm{lb}$. can be netted, but over this weight it is safer to use the gaff.

In netting, the net should be quietly put under the fish, lifted up, and then pulled towards the shore. This is infinitely better than lifting it clear of the water and bringing the whole weight of the fish on the net. The great thing to remember is to get the head of the fish away from the side of the net before lifting. If this is not done the hooks are apt to catch in the net, the head does not get down, the tail part falls over the ring, the fish is outside, the hooks are attached to the net, there are one or two wriggles, and the fish is gone. A gillie should never attempt to net or gaff a fish while wearing white sleeves, nor run up and down after a fish; he should rather wait quietly in one place and reach out the gaff when the fish passes him. Many a time when alone I have dirtied the water by stirring up the mud at the side with my feet ; when the fish has been guided into the muddy water it cannot see any one, and the gillie is therefore quite safe in walking in and gaffing it.

Another opportunity of gaffing a fish may be obtained when the fish's head is out of the water, for in that position it cannot see. If both the gaff and net have been accidentally left behind, the best way of landing a fish is by first tiring it out and getting it to turn 
on its side. It can then be pulled up into shallow water. A very large fish can be pulled up in this fashion. Every time it moves a little pressure is put on, and in this way it can be brought on to the gravel and gradually landed high and dry. The gillie may then go forward and catch it by the tail, and push it farther up or lift it on to the bank.

Harling a River from a Boat.-This method of fishing is only resorted to on large rivers where the pools cannot be conveniently fished from either bank. It is done by placing two or three rods in the stern of the boat, one at each side and another in the centre. A fly is attached to each rod, a minnow sometimes being substituted for one of the flies. From twenty to forty yards of line are let out from each reel. Two gillies row the boat from one side to the other, dropping down a yard or two at a time.

To be successful, the gillie must have a knowledge of the river in its different heights. He must also be able to tell the angler the proper length of line to put out, the bait line always being a yard or two shorter than those with flies, and the proper kind and size of flies to use. The gillie must also know the proper angle at which to keep the boat, so that the lines and flies may be kept in correct position. In turning, the boat should be brought slowly round so as to give the flies plenty of time to turn. Observant gillies who take an interest in their work always excel in this style of fishing. 
Trolling or Salmon Minnow-Fishing from a Boat. -In this method of fishing the gillie's duty is to find out which parts of the loch the fish frequent; the different depths of the loch, so as to avoid fouling in the bottom or coming against hidden rocks ; the kinds of bait to use (and to see that they spin properly); the proper length of line to put out; the correct weight of lead to put on the trace; and the direction of wind which affects certain parts of the loch. He must also know how to take the bait over a fish which has been seen to rise, without taking the boat over the place and disturbing the fish. Care should be taken to row sufficiently fast so as to make the bait spin. When a fish is hooked, the boat should not be pulled all over the loch. Many gillies are never content unless they follow that bad practice, and they sometimes kill a fish a mile away from where it was hooked, thereby wasting valuable time and disturbing the water for the chance of other fish.

Trout-Fishing from a Boat in a Loch.-In Scotland more gillies and keepers are employed at this style of fishing than any other. The angler depends on them for his sport and pleasure. As a rule, the sport is proportionate to the knowledge of the gillie. The gillie's duty is to obtain a perfect knowledge of every part of the loch, its deeps, shallows, and bays, and the places where trout frequent at different seasons. He should know at all times where he is, the depth of water he is fishing, the nature of the bottom-whethergravel, rocks, 
mud, etc. - the places and time of day the flies hatch out, the direction of winds that suit the different places, the effects of cold and heat, sunshine and shade, the different kinds of flies-whether strong or fine tackle should be used-how to keep the boat to the wave in drifting, whether the bow or stern should point to a certain direction, and whether the boat is drifting too fast or too slow.

If there be only one angler in the boat, the gillie should be able to advise which end he should fish from, and whether it would be better to row the boat instead of allowing it to drift. All these points should be carefully studied and mastered before the gillie can be said to be an experienced one. When a trout is hooked, the net should be quietly put under it and then lifted out, the fish being caught with one hand, and the hook extracted with the other. The fish should then be knocked on the head, as nothing is more disgusting than to have a trout half-dead wriggling about in the basket.

There is a great art in taking out a hook; those who know how to do it can extract it very quickly without bending the iron or breaking the barb or destroying the fly. The cast and hooks will often get entangled, but the experienced gillie, with one or two shakes, will be able usually to set them free. These are some of the principal points the experienced angler depends on for filling his basket.

A clever gillie is always sought after. $\mathrm{He}$ is 
usually an agreeable and pleasant companion. I know of such a gillie. One I have in my mind I have known for upwards of thirty years. I considered he was the means of adding Io lb. daily to my basket. He is far and away the cleverest gillie I have ever had. The way in which he lands a trout, extracts the hook, and unravels the cast is simply marvellous, the time he takes being little longer than it takes to make a cast. The way he will row to the centre of a loch and turn round the boat within thirty yards of a sunken island requires to be seen to be believed. This gillie is worth double the usual wage, and I am quite sure he gets it.

The worst enemy the gillie has to contend with is drink. It is very unkind of an angler to give his gillie more than is good for him. I dare say I employ more gillies than any man in Scotland. I always impress upon them never to make complaints or grumble to the anglers they are attending upon who come for sport and pleasure. The more they are assisted in the habits of temperance the better it is for all concerned.

\section{Note on the Improvement of Loch-Fishings}

It is in every way desirable for the improvement of loch-fishings to attend to the following points :-

Throughout the autumn and winter, keepers and gillies usually have abundance of spare time, and are at a loss how best to employ it. To such I would strongly advise turning their attention to the stocking and improving of any lochs that may occur on their employers' 
estate. All over Scotland there are lochs and streams containing far too many trout, and others again with few or none. To remedy these defects is, to the intelligent gillie, a most interesting and fascinating work and a source of pleasure and profit to his employer. How pleasant to tell your master you introduced forty or fifty small trout into a small lake of his not more than two acres in extent four years previously, and now he can see them for himself rising of a summer evening like miniature salmon. Excitement takes possession of him and he is not content until an opportunity presents itself of his casting over them. Then, $\mathrm{O}$ what joy, when a dozen lusty fellows from 3 to $5 \mathrm{lb}$. grace his basket! The puny little loch once his pet aversion, now a joy to all, and none more so, than to the gillie who had taken the trouble to stock it.

The gillie must not, however, lose sight of the fact that where there is no spawning ground he cannot expect to maintain a stock unless he keeps on making up the numbers by introducing others. If none be added to make up the deficiency, in a short space of time most will have disappeared, as the life of a trout does not exceed more than from seven to eight years.

When trout are introduced into a loch for the first time, the feeding is generally so rich that they grow very rapidly. Most lochs, if not too deep, can sustain from 100 to 200 trout per acre, so that when only 20 to the acre are introduced they have more than sufficient food and quickly increase in size. 
Every gillie should have a large landing net and pail to carry trout from one place to another. By netting the small streams rooo trout can often be caught in a day and distributed over several small lochs and allowed to grow at their own sweet will. On reaching from $\mathrm{I} \frac{1}{2} \mathrm{lb}$. upwards they will give capital sport to several rods for a whole season. Much can be done in this way, whilst other lochs containing too many trout and too small to give sport, can be netted and transported to another, or the spawning-ground can be curtailed, when their numbers will soon be lessened.

On many occasions I have known anglers capture a score of small trout with rod and line and carry them to some other troutless loch, and in after years recapture them of a takable size. This is a slow process, but answers the purpose quite well, and serves to show what can be done in this primitive way. Lochs that are too shallow can be deepened by raising the outlet by means of a few stones. An hour or two spent at this is often the means of opening up many acres of fishing-ground, formerly covered with weeds. Other lochs of too deep a nature for producing food can be made shallower by deepening the outlet, little falls can often be blasted and allow of trout entering a loch. Many other points will occur to the observant gillie, which he should bring to the notice of his employer. I know of no other branch of sport that is so much neglected as the care of and improving of troutfishing. 
Proprietors put themselves to no end of trouble to obtain an extra brace of grouse, but pay no attention whatever to trout, which are equally valuable.

Hotel-keepers come under the same category ; they will take every trout they can out of their lochs, without ever giving one single thought to restocking them. 
NOTES 


\section{CHAPTER XX}

Some Broad Facts in Angling Law

By HENRY LAMOND

(Secretary of the Loch Lomond Angling Improvement Association)

IT would be absurd to attempt to comprise within a single brief chapter a compendium of the law of fishing in Scotland, if at the same time one were expected to advance reasons and authority for each proposition stated. Proprietors and their keepers, or fish watchers, however, need never be at a loss on any given point if the country-house library contains, as it ought to do, Stewart's Treatise on the Law of Scotland relating to Rights of Fishing, and Tait's useful book on The Law of Scotland on the Game Laws, Trout, and SalmonFishing. In both of these care must be taken to distinguish between what has actually, in recently decided cases, been found to be law and what is merely the author's opinion. A useful feature of these books is that they give as appendices the Salmon Fishery Acts from I 828 to $I 868$ as well as the Trout Acts of 1845 and 1860 , but not the recent Trout Act of 1902 . With these Acts every fish watcher should be familiar, because it will add much to the value of his services $3^{6} 3$ 
if he has made an intelligent study of them. Not only so, but besides giving him, or indeed any keeper, confidence in his work, it is safe to say that friction and misunderstanding will be absent from a neighbourhood where rights are clearly understood and equitably insisted on. The aid of his legal adviser must of course be invoked by a proprietor before actions of interdict regarding fishing, pollution, or rights of way are thought of, or even before poaching prosecutions are contemplated, but the following brief notes may be of guidance in an emergency, or may help to support an argument.

\section{Salmon}

\section{Legal Definition}

By statute the word "salmon " means and includes "salmon, grilse, sea-trout, bull trout, smolts, parr, and other migratory fish of the salmon kind" (I862 Act, Section 2), and in this comprehensive sense the word is here used.

\section{Public Rights}

There is no public right of salmon-fishing in Scotland, either in salt water round the shores or in fresh water. Where the right is not in the hands of a private proprietor it is vested in the Crown, and administered, or neglected, by the Department of the Commissioners of Woods and Forests. Hence any person fishing for salmon, whether by net, or by rod and line, without 
a title, or without express written permission from one who has a title, is, in the eye of the law, a poacher and liable to be prosecuted. (I 844 Act, Section I.)

\section{Private Rights}

These are too involved to permit of a useful summary being given.

\section{Close Times}

These vary in different localities. The foundation for them is Schedule C annexed to the 1868 Act, but several alterations have since been made, under powers contained in that Act, on petition by District Fishery Boards to the Secretary for Scotland. The appended Table (see p. 380 ) gives a compendium of the close times for the whole of Scotland as in force at January I9IO.

\section{Exercise of the Right}

Apart from some few survivals of an ancient time, the result of special Border legislation, the only legal means of netting salmon within rivers and estuaries is by " net and coble," and also, of course, by a landing net used as an adjunct to rod and line. The limits of all estuaries are laid down in Schedule B annexed to the 1868 Act. The legal mesh of a salmon net is not less than " $\mathrm{I} \frac{3}{4}$ in. in extension from knot to knot, measured on each side of the square, or 7 in. measured round each mesh when wet"; while any device, such as placing two nets together, intended to diminish the mesh, is illegal. (Schedule E, r868 Act.) The centre 
of each knot, it has been decided, may be taken as the basis of measurement.

\section{Poaching and Illegal Practices and Tackle}

The following may serve as a rough guide to the numerous offences specified in the various Salmon Acts. It is illegal under-

I. The Salmon Fisheries (Scotland) Act, 1828.I. To trespass in any ground, enclosed or unenclosed, or any river or estuary, with intent to kill salmon. (Section 3.)

2. To break the law regarding cruives laid down in the 1877 Act; i.e. to let the hecks remain shut during Saturday's slop, or have them measure less than 3 in. wide. (Section 7.)

2. The Salmon Fisheries (Scotland) Act, I844.To take, fish for, or attempt to take salmon in all inland waters which salmon frequent, or in any estuary, firth, sea loch, creek, bay, or shore of the sea, or any part of the sea within one mile of low-water mark, or to assist others in doing so, without having a legal right or permission from the proprietor of the salmon fishery to do so. (Section I.)

3. The Salmon Fisheries (Scotland) Act, I862.I. To put into a salmon river any poisonous or deleterious liquid or solid matter to an extent injurious to the fishery, failing proof (open only to persons having a prescriptive 
right to pollute) of having used beforehand the best practical means, within a reasonable cost, to dispose of or render it harmless. (Section I 3.)

2. For three or more persons acting in concert, at any time between one hour after sunset and one hour before sunrise, to enter or be found upon any ground near a river, estuary, or the sea, or actually upon these waters, with intent to kill salmon, or to have in possession any net, rod, spear, light, or other instrument for that purpose, or to engage in, attempt, or aid in doing so. (Section 27.)

4. The Salmon Fisheries (Scotlana) Act, I863.To export unclean or unseasonable salmon, or salmon caught in a district during the time at which the sale of salmon is prohibited within the district. (Section 3, and 1868 Act, Sections 21 and 22.)

5. The Salmon Fisheries (Scotland) Act, I868.-

I. (I) To catch salmon otherwise than by rod and line during the annual close time for nets.

(2) To catch salmon (except during Saturday or Monday by rod and line) during the weekly close time, or to contravene any bye-law in force regarding its observance. Note.-This makes Sunday' rod-fishing for salmon illegal. 
(3) To catch salmon by rod and line during the annual close time at a period not authorised by bye-law. (Schedule $\mathrm{C}_{\mathrm{t}}$ )

(4) To fish for salmon with a net of illegal mesh. (Schedule E.)

(5) To intercept salmon when leaping at an obstruction, or when falling back after leaping.

(6) To prevent salmon passing through a fish pass, or to take them in the passage through.

(7) To put sawdust, chaff, or shelling of corn into a river.

(8) To contravene any bye-law. (Section 25.) Note.-In each of the above offences, attempting, or assisting, is also punishable as an offence.

2. To use any light or fire of any kind, or any spear, leister, gaff, or other like instrument, or otter, to catch salmon, or to have such articles in possession under suspicious circumstances; excepting a gaff used in angling with rod and line. (Section I7.)

3. To fish with any fish roe; or to buy, sell, or expose salmon roe for sale; or to have it in possession; excepting its use for artificial propagation or other reason satisfactory to the Court. (Section 18.) 
4. To take smolts or salmon fry: or to buy, sell, or expose them for sale; or to have them in possession; or to place any device or engine to obstruct their passage; or wilfully to injure them; or to injure or disturb salmon spawn; or to disturb any spawning bed in which spawn may be; or, during the annual close time, to obstruct salmon in their passage to the spawning beds ; $e x$ cepting for artificial propagation or scientific purposes, cleaning or repairing a dam or mill lade, or exercising a right of property in the bed of the stream. (Section 19.)

5. To take, fish for, or attempt to take, unclean or unseasonable salmon, or assist in doing so ; or to buy, sell, or expose them for sale ; or to have them in possession; excepting such as may be accidentally taken when fishing if the same be forthwith returned to the water with the least possible injury; and excepting those taken for artificial propagation or scientific purposes. (Section 20.)

6. To buy, sell, or expose for sale, or have in possession salmon taken between the commencement of the latest and the termination of the earliest annual close time in force for any district. (Sections $2 \mathrm{I}$ and 22, and I 863 Act, Section 3.) 
7. For proprietor or occupier of a fishery within thirty-six hours after the commencement of the annual close time, to fail to remove, and effectually secure against being used, all boats, oars, nets, engines, and tackle; $e x$ cepting angling boats and oars, family boats and ferry boats identified by owner's name and kept under lock and key when not in use ; and for the proprietor or occupier of a cruive within the same time to fail to remove and secure all hecks, rails, and inscales, and all temporary obstructions. (Section 23.)

8. For a proprietor or tacksman of fixed nets to evade the bye-laws regarding the observance of a weekly close time. (Section 24.)

Powers of Keepers and Water Bailiffs.-To be dignified when courtesy is out of place, to be angry without loss of temper, and to use force without violence, is instinctive with a first-class keeper. He must read the Acts to understand the extent of his powers. In these, it will be observed, there are three classes of guardians of the law referred to, viz.-(I) private individuals, the "any persons" of the Acts, (2) officers and authorised employees of District Fishery Boards, and ( 3 ) police officers.

1. Unless he be in service of a District Board, the keeper or fish watcher has no higher powers than any man in the street and must 
comport himself accordingly. The Acts make some exceptions, however. Section I I of the I 828 Act makes it lawful for any person, without other authority than the Act itself, brevi manu to seize and detain an offender-the offence under Section 3 being apparently contemplated. Having seized him he may carry the offender before a Justice of the Peace or other magistrate, or hand him over to a police constable to do so, when he will be further dealt with as the Act prescribes. ${ }^{1}$ Section I of the $\mathrm{I} 844$ Act gives similar powers to any person who may further seize the fish, boat, tackle, and nets of the poacher. The watcher has no right of search unless he be an employee of a District Board or a police officer. Finally, Section 29 of the I 868 Act gives similar powers to the private watcher to seize offenders against the first six subdivisions of Section 1 5, and Sections 17, 18, 19, 20, $2 \mathrm{I}$, and 22 of the Act.

2. Employees of District Boards are statutory officers and have statutory powers which the Acts make clear.

3. Police officers, although specially authorised by the Acts, to take certain steps in certain

${ }^{1}$ Brevi mamu, though it means coming to grips, does not excuse a violent attack. 
cases, will as a general rule be found willing to extend a helping hand to maintain law and order when occasion arises. They are not bound to originate plans of campaign against poachers, but ought to act when flagrant cases come under their notice.

The Fishmongers Company of London.-No other organisation has done so much to conserve our Scottish salmon fisheries. In general, but specially in cases where there is no District Fishery Board, the Company or its local solicitor, being "any person" in the sense of the Acts, will prosecute offenders. It is requested that information as to offenders may be sent in confidence to the Clerk, Mr. J. Wrench Towse, 24 Charlotte Square, Edinburgh, or Fishmongers Hall, London.

\section{TROUT}

\section{Legal Definition}

In the latest statute the legal expression used is " the common trout, salmo fario" (I9O2 Act, Section I), but the definition has been held to include Loch Leven trout, salmo levenensis, in a Sheriff Court case.

\section{Public and Private Rights}

I. The Public.-There is no public right of troutfishing in Scotland, except in navigable rivers so far up only as the tide ebbs and flows, and in those few 
fresh-water lochs which are at once tidal and navigable. The right belongs exclusively to proprietors of lands adjoining the fishing, and neither the custom of fishing for any length of time, nor lawful access to the water by boat, bridge, ford, ferry, right of way, or otherwise, will give to the public a right to fish for trout.

2. Tenants.-Apart from agreement, an agricultural tenant has no right to fish for trout in respect of his lease. On the other hand, the lessee of the salmon fishings, if any, has an implied right to fish for trout.

3. Private Proprietors.-As between proprietors the following broad rules obtain according to Scottish law, and an intelligent keeper, or fish watcher, will keep them in view in order to protect his employer's interests, or at least to escape causing needless friction between neighbours.

(I) Private Rivers. - A private river, as regards trout-fishing, is one in which the proprietors may exclude the public from fishing. That is, all those except such as are at once tidal and navigable, and only in so far as they are so. Where a river intersects one proprietor's lands, he alone has the right to fish in it for trout. Where the river is the boundary of opposite proprietors' lands the law declares (apart from title, which may rule otherwise) that the centre of the stream is the boundary. 
Each proprietor may wade to the centre, fishing from his own bank, but the Court has expressed an opinion that from the practical difficulty of doing otherwise he need not confine his casting radius to his own side of the water. In a river there is an interest in the trout, as in the water itself, common to upper and lower proprietors. The exclusive right of property mentioned is in the right to fish, not in the trout itself, which is a fera natura and belongs to the catcher, unless-(I) it be taken from a pond, stank, or artificially stocked reservoir, when it is theft to take it, or (2) it is forfeited by statute.

(2) Private Lochs. - A loch is private where the proprietor or proprietors may vindicate their right to fish for trout as against the public, that is, every loch which is not both navigable and tidal. If a loch be situated wholly within the lands of one proprietor, he alone has the right of trout-fishing in it. If the loch verge upon the lands of two or more proprietors, they have an equal right of fishing over the whole surface irrespective of the extent of their foreshores. Unless restricted by the Court-no instance of which has yet occurred-each proprietor may communicate his right of fishing to an indefinite number of persons, and put upon it an indefinitc 
number of boats. The right to land, however, is confined, as regards proprietors and those to whom they have given permission to fish, each to his own shores.

(3) Public Rivers.-A river is only public as regards trout-fishing to the extent that the public may fish in it for trout, flounders, and other floating fish, except salmon, as far up as it is both tidal and navigable. In this sense it is not public where it is only tidal, or where it is only navigable, and in these cases the rules of fishing applicable to private rivers apply. The "publicity" of a non-tidal navigable river consists in a mere right of passage by boat on the surface of the water, and gives no public right to the water, or its inhabitants, or the solum. Where a river is tidal and navigable, it, and its solum (broadly speaking), is vested in the Crown for behoof of the public's right of free navigation and white fishing, which is the sole basis of any right of trout-fishing which the public possesses.

(4) Public Lochs.-On legal principle alone, no lochs in Scotland, except such as are both tidal and navigable, can be held to be public as regards trout-fishing. Where they are not at the same time tidal, access to them either by a navigable river, or by a canal, will not 
confer a right of trout-fishing on the public, whose right is no higher than in the case of a non-tidal navigable river. It is right to warn inquirers that Stewart in his book makes some very misleading observations on this subject, through a failure on his part to make clear the exact extent of the rights of the public in a navigable river.

Close Time.-This extends from the $15^{\text {th }}$ day of October to the 28th day of February, both dates inclusive. (I902 Act, Section r.)

\section{Poaching and Illegal Practices and Tackle}

I. Act of Scots Parliament, James VI., I607.-It is theft under this old Act to take trout from a stank or pond.

Note.-A prosecution under it was upheld by the Court of Justiciary in the case of a reservoir artificially stocked with trout, December I909.

2. The Trout (Scotland) Act, I 845.-It is illegal under this Act for any person (other than proprietors or those having their written permission)-

(I) To net trout or other fresh-water fish in any river, water, or loch, or to attempt to do so, or aid or assist in doing so or attempting to do so. (Section r.)

(2) To trespass upon any ground, enclosed or unenclosed, or any river, water, or loch with intent to net trout or other fresh-water fish. (Section 2.) 


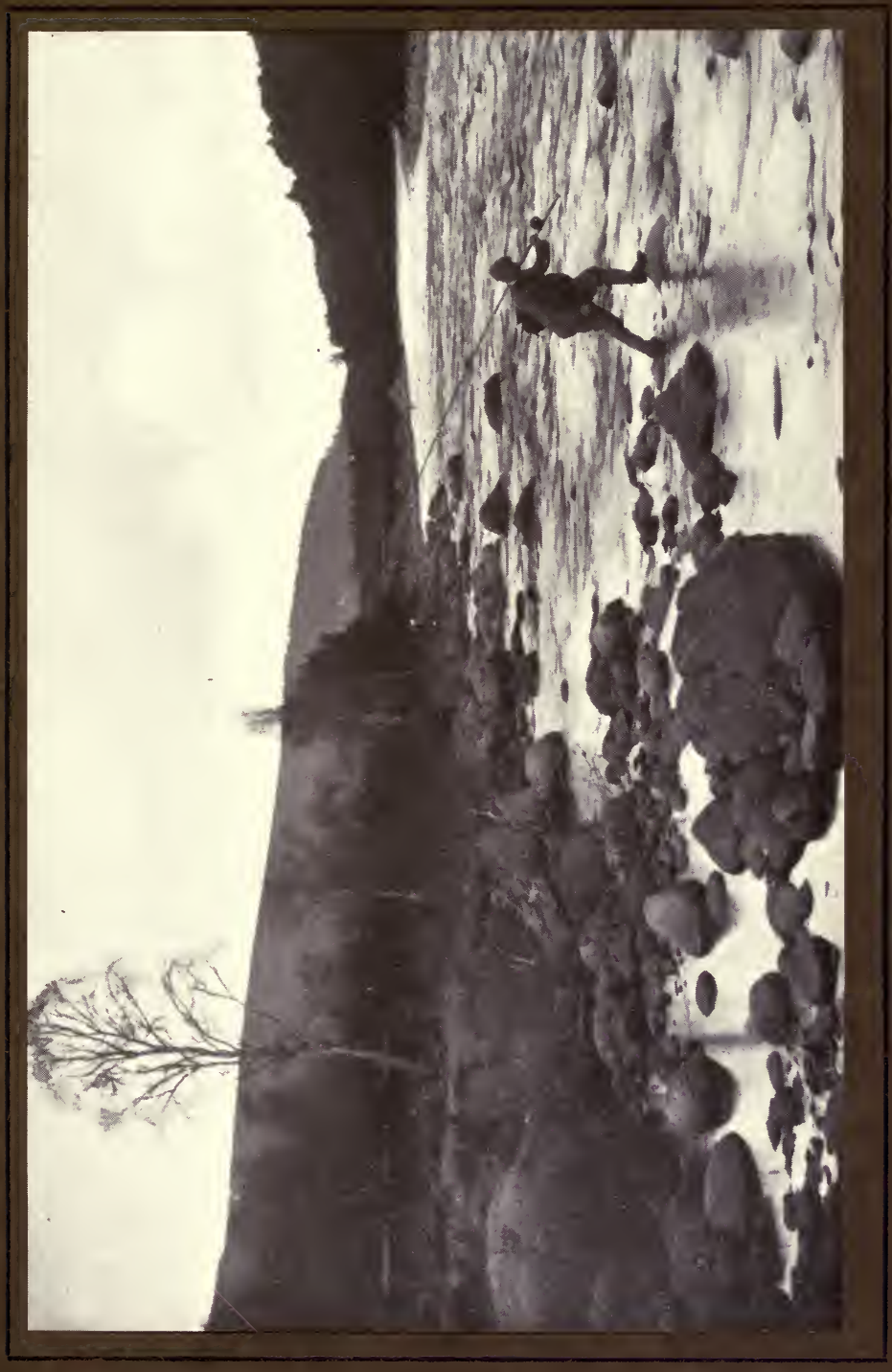

0
$\frac{0}{x}$
$\frac{1}{2}$
0
$\frac{2}{0}$
0
0
0 

3. The Trout (Scotland) Act, i 860.-It is illegal under this Act for any person (other than the proprietors or those having permission) -

(I) To net trout or other fresh-water fish, or to fish for them by double rod fishing, or cross line fishing, or set lines, or otter fishing, or burning the water, or by striking the fish with any instrument, or by pointing, or to put into the water lime or any other substance destructive to them with intent to destroy them, or to attempt to do so, or aid in doing so, or attempting to do so. (Section I.)

Note.-It has been held in two Sheriff Court cases that a rod mounted with worm tackle fixed to the bank of a loch is a set line.

(2) To trespass upon any ground enclosed or unenclosed, or any river, water, or loch, with intent to commit any of the above offences. (Section 2.)

4. The Fresh-Water Fish (Scotland) Act, 1902, makes it illegal-

(1) (a) To fish for or take trout in any river, water, or loch in Scotland by net, rod, line, or otherwise; or (b) have possession of trout ; or $(c)$ expose trout for sale during the close time. The Section excepts operations for artificial rearing and sale for restocking; but sale of dead trout or live trout from waters where they 
are reared or kept in captivity for food during the close time is prohibited. (Section I.)

(2) For proprietors, or those having written permission to fish, to do any of the acts made illegal for other persons by the 1860 Act; except-( 1 ) that all the proprietors of a pond or loch may agree to net "trout," and (2) that a net may be used for scientific, breeding, or restocking purposes. (Section 2.)

(3) To use or attempt to use dynamite or other explosive to catch or destroy "fish" in any river, water, or loch. (Section 3.)

\section{Powers of Keepers and Water Bailiffs}

Keeping in view previous general remarks when considering the Salmon Acts, it may suffice to say generally that one may take any lawful steps to protect one's property. The I845 Act (Section 4), however, gives to any person, without other authority than the Act, a right brevi manu to seize offenders against the Act and carry them before a Sheriff or Justice of the Peace, or hand them over to the police to be summarily dealt with. Power to seize boat, net, and fish is also given. The r860 Act (Section 3) gives power only to proprietors, and to any persons authorised by them, to seize boats, nets, and other tackle used in contravening that Act, and any fish taken. Both these Acts are to be read along with the 1902 Act in all matters not 
inconsistent with the latter. It is usually the Procurator-Fiscal who prosecutes under the 1902 Act; but any person "having an interest" may do so.

\section{CoARse Fish}

There are no special legal restrictions in Scotland as to the capture of coarse fish, and it is doubtful whether the prohibitions as to their capture by net or otherwise, as in the case of common trout, apply to them. There seems to be no direct decision on the point. The 1902 Act, however, makes it illegal to kill them with explosives.

There is no close time for such fish in Scotland.

As in the case of common trout, the right to fish for them belongs to the proprietors adjoining the waters in which they exist, except where the tide ebbs and flows in a navigable river or loch, in which case the public may fish for them without challenge. 


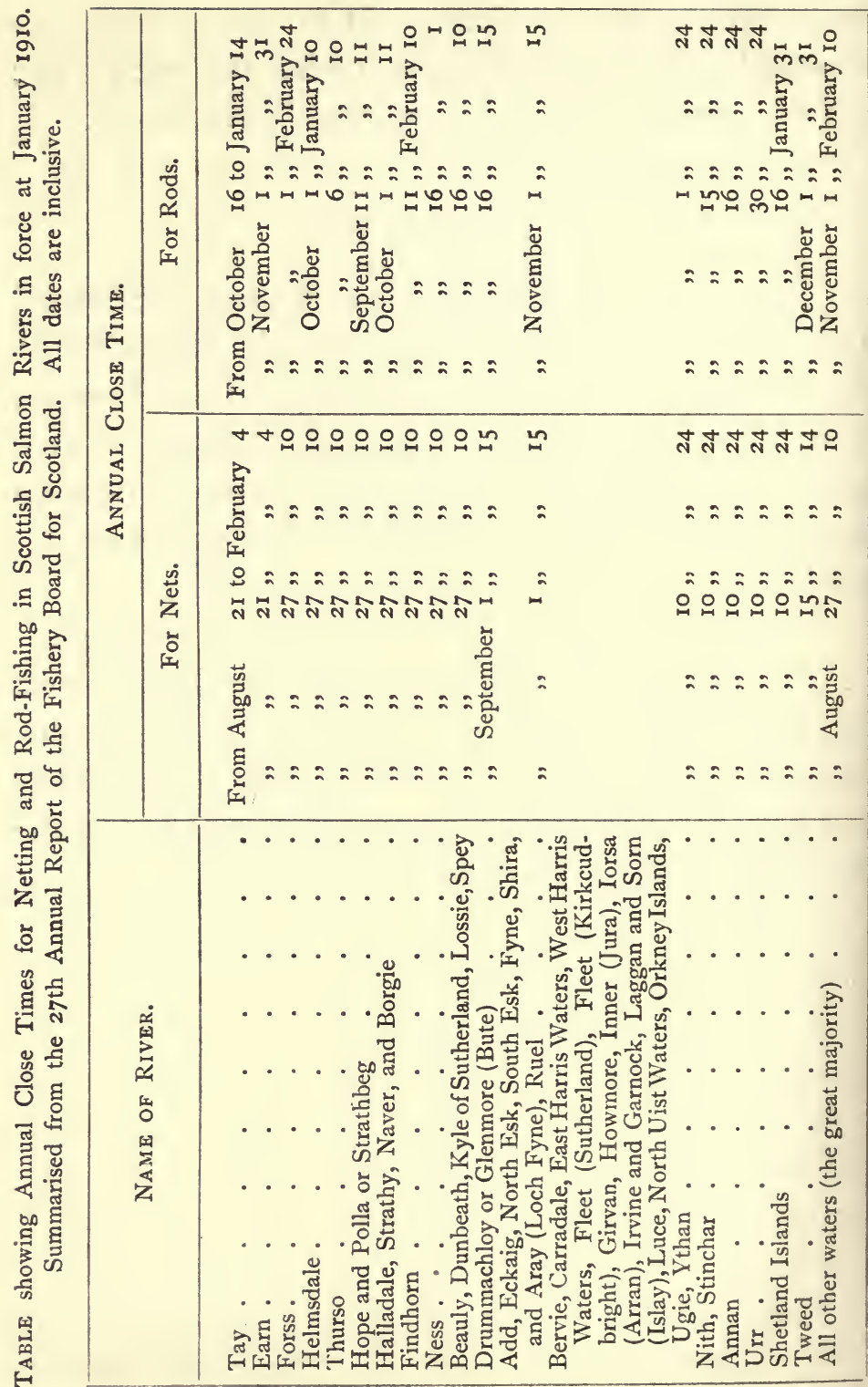


NOTES 


\section{NOTES}




\section{CHAPTER XXI \\ The Rod in Salt Water}

By F. G. Aflalo

THese notes on sea-angling for sport are intended to be helpful to the gillie. Whether they prove so will depend more on the gillie than on the notes. His general duties have been admirably summarised in the earlier chapter written by Mr. Malloch. But the case of seafishing is somewhat different from the duties which he had under review. Sea-fishing is a comparatively new sport-it is not much more than a quarter of a century old-and has not yet been reduced to the same exact science as some other kinds of angling. Among many advantages it is at its best in those weeks of July which precede activity on the moors. Now, gillies who take sportsmen after salmon or trout know their work more or less (occasionally less), and he is a bold man who tells them their own business. I have had gillies in both hemispheres and five continents: garrulous Greeks, imperturbable Moslems, lazy Spaniards, independent Yankees, merry Basques, blasphemous FrenchCanadians, but only one Scotchman. He was really a gamekeeper, and he once as good as told me I was 
a fool. I have rather cherished the memory of his red beard and beady eyes ever since. As a seeker after truth, he had not his equal in the whole boiling of them.

If the sportsman on whom the gillie is in attendance knows what he is about, then the gillie's job is simple: he merely has to do as he is told, handling the boat or gaffing the fish as directed. There are, of course, gillies who do not find doing as they are told very easy. They always think they know better than their employer. Sometimes they are right, but even so, I always make it clear, in a quite friendly manner, that I am fishing for my pleasure, not for theirs.

For convenience of division, the subject will be dealt with under the heads of fish, tackle, bait, and general hints, with such incidental notes on various matters as may suggest themselves.

(I) The Fish. ${ }^{1}$ - The colder seas of Europe are not the best in the world for fishing, for, unlike the salmon and trout, the most sporting salt-water fishes grow to the largest size in warm latitudes. I have caught bass of $\mathrm{I} 7 \mathrm{lb}$. in Turkey, and tarpon upwards of $100 \mathrm{lb}$. in Florida, but nothing in British seas of more than $30 \mathrm{lb}$., and that was a shark. Even within the limits of these islands this difference is appreciable, and the bass and grey mullet, two of the gamest sea-fish, are finer and

${ }^{1}$ Having only fished off Taynuilt and elsewhere in Loch Etive, I have been guided, as regards the west coast of Scotland, by the admirable Fauna of the Outer Hebrides, by Harvie Brown and Buckley (David Douglas, 1898), a work that is now out of print, like some others of the same excellent series. 
more plentiful in the English Channel than in Scotch waters, where the best of the fishing is for lythe and saithe, or, as they are called in England, pollack and coalfish. Indeed, in these colder seas, the fishes of the cod family are the most conspicuous, including the aforesaid ly the and saithe, the cod, haddock, whiting, and torsk. The last four are ground-feeding fish, and must be caught from piers or anchored boats, with the bait on or near the bottom. The cod and whiting are widely distributed, but the haddock (like the hake, a larger cousin) is "uncertain, coy, and hard to please," and comes and goes without why or wherefore. These fishes are almost too familiar to need description. The heavy-looking cod, brown on the back and white beneath, with a little beard on the lower jaw ; the haddock, with the black mark on its shoulders and the family beard; the whiting, smaller and more silvery, and beardless ; and, in all, the line along the sides showing plainly, white on the cod, black on the others, and very marked in the haddock. The lythe and saithe (English : pollack and coalfish) are predatory fish, and they stand in relation to the more ponderous cod and torsk as the eagle to the buzzard. They readily seize a moving bait near the surface (even a large fly or bright spinner will take them), so that they are best caught by casting from the rocks or by trailing the baits behind a boat. They bear some resemblance, but the saithe is blue rather than green and has a small beard, which is missing in the other. Both these fish abound on all rocky ground 
all round these islands, but the saithe is most plentiful in Scotch waters, and dwindles in numbers as we go south, whereas the pollack is as plentiful in the English Channel as anywhere. Three other members of the cod family call for passing mention. Of these, the hake and ling grow to a great size, while the pout, or " rock whiting," rarely exceeds $5 \mathrm{lb}$. The hake is a long grey fish, with formidable teeth and no beard. It grows to a weight of $25 \mathrm{lb}$., and is found in pursuit of the herring. The ling, which is still more elongated, and not unlike a conger with a beard, grows to a $100 \mathrm{lb}$. weight, and has probably the heartiest and most accommodating appetite of all our British fishes, and even swallows such dainty morsels as halibuts and sharks. Nor is there any immediate fear of the species dying out, for a fullgrown female has been found to contain 100,000,000 eggs!

The mackerel is one of the gamest fish in our seas. Only its small size is against it. If it grew as big as ling or lythe, there would be no need to go to California for tuna. But as it rarely exceeds $4 \mathrm{lb}$., only the lightest of rods and tackle should be used when mackerel are to be caught for sport. Catching them for the market is another matter, and either drift-nets or handlines must be employed. It is for sport that the use of light tackle is advocated, and not, as for bass and grey mullet, because it is more likely to deceive the fish, for mackerel will take almost any bait, and, when in the mood to feed, almost any tackle. As they do not like 
the temperature of the water to fall much below $45^{\circ} \mathrm{F}$., they are more plentiful in the English Channel than farther north, but they are to be found all round the Scotch coasts, and the absence of a fishery on the west side is not their fault, but that of the fishermen.

There are several kinds of flatfish which give the angler sport-plaice, dabs, and flounders are the chief. The plaice is known by its red spots, the dab by its rough scales, and the flounder by its dark markings and a few rough scales along the curved "lateral line." All three feed on the sand, where they may be caught with fine tackle and small hooks baited with sandworms or mussel. Two of the larger flatfish, turbot and halibut, are also occasionally caught by amateur fishermen. Turbot occur in the more southern waters of Britain and rarely exceed $25 \mathrm{lb}$. They have rough scales on the dark or upper side, and feed on small fish or shellfish. Halibut (which in many parts of Scotland are known as "turbot") grow to a weight of 200 or 300 lb., and are caught by sportsmen at several places on the Irish coast, notably at Ballycotton.

The gurnards, also ground-feeders, are easily recognised by their grotesque heads, as well as, in some of the kinds, by their brilliant colouring, with various combinations of blue and scarlet that make them, with the wrasses, the smartest fish of our seas, which do not favour such gay attire as those of the tropics. Properly cooked, the gurnards are good table fish, but he is an emotional sportsman who can find much pleasure in 
catching them. The best sport I ever had with these fish was in a little backwater of the Gulf of Ismidt, in Asia Minor. The water was so still and clear that, even in three or four fathoms, one could see the great scarlet gurnards crawling slowly over the bottom, and a bait dropped in front of their nose on a single gut line, with a light rod, was instantly seized, and a few moments of fair sport would result. So, later in the day, would a baked gurnard.

Both bass and grey mullet-I bracket them merely as our most sporting marine fish, and not for any family connection-occur on the west coast of Scotland, and of large size, but the English Channel is their true home in these islands, as they are Mediterranean forms. The bass is a handsome, silvery, perchlike fish, with a big head and prickly fins. The mullet, also silvery and less like a perch, has a small head and mouth and softer fins.

They differ much in their habits, except that both are fond of the mouths of rivers and of haunting piers and docks for the food they find there. The bass, however, is a predatory fish, chasing the sandeels and other fry, and therefore seizing moving baits near the surface. The grey mullet (which must be distinguished from the totally different red mullet) is a vegetarian in great part, though it will take ragworms, and occasionally, particularly about sunset, a white fly. In our seas neither are taken on the rod weighing much over Io $1 \mathrm{~b}$., though bass of $15 \mathrm{lb}$. are occasionally recorded ; but in warmer seas these weights are frequently exceeded. I have 
taken bass in Turkey of $I 7$ lb., and in the Persian Gulf sportsmen catch mullet of $\mathrm{I} 8 \mathrm{lb}$.

The John Dory is another warm-water fish and is at its best in our south-west coast, in Cornwall, where it reaches a weight of $18 \mathrm{lb}$. In fact, I never heard of a large dory being caught much north of a line drawn between the estuaries on the Thames and Severn. This fish has as ugly a face as any in our seas, but this does not prevent its being excellent eating. No one goes fishing specially for it, but one is occasionally taken in swallowing a smaller fish already on the hook, and then, being probably overheavy for the tackle, it must be played cautiously to the landing-net or gaff.

The only other big sea-fish caught on the rod in this country are congers, skates, and sharks. The conger is a great eel that lives in the rocks and is caught on very strong tackle, chiefly at night. The skates, or rays, are those great, square, flattened fishes with the long, whiplike tails, the latter being in some cases furnished with sharp spines. Like their relatives the sharks, they have their eyes above the head and their mouth beneath. The upper surface is usually dark brown or grey, and the lower white. They live on the sand and will take any large bait that lies there, and they show about as much fight as one would expect from a billiard table. For this reason I have always had difficulty in believing that there are men who deliberately set out to catch skate for their own amusement, but it is a fact that they do so. 
The sharks and dogfish are also only caught accidentally, save at a few spots on the coast, like Herne Bay, in Kent, and Filey, in Yorkshire, where dogfish up to $50 \mathrm{lb}$. are made a special object of sport. Otherwise, they are caught only when they seize a hook meant for pollack or some other large fish. I have taken both sharks and porbeagles in Cornwall up to $20 \mathrm{lb}$. or $30 \mathrm{lb}$., and both these species occur in Scotland. At times the smaller spotted and rough dogfish occur in such swarms that fishing is impossible, and the only thing for it is to get up the sail and go back to the harbour. The same plague used to inflict itself on us in Australia, only we used to go snapper-fishing in steam tugs, and it was easy to steam away to fresh grounds and outdistance the greedy vermin that give no better fish a chance.

Among other large sea-fish, the rarest catch in the amateur's diaries is an angler-fish. It is not that this curious creature is scarce, for, on the west coast of Scotland, at any rate, it is plentiful. But its manner of catching its food does not expose it to much risk from the angler's hooks. The fish simply lurks in the shade of a rock or in an ambush of weed, and dangles a silvery bait on a kind of fishing-rod that grows on the top of its head. Little fishes, which are as curious as little women, gather round to see what the strange object is. Perhaps they nibble at it, but, whether they do or not, the enormous mouth beneath suddenly opens, and they are carried inside by the rush of water. Nor is the angler-fish satisfied with such modest fare, for large 
skate and conger have been found in its stomach. It will, however, be seen that only by the merest chance would a baited hook dangle within reach of its jaws. Still, it does occasionally happen that one is caught on a rod or line, and then it is a case of Greek meets Greek. But if any one will show me the man who would deliberately go forth to catch an angler-fish, I will show him a man ripe for the asylum.

(2) The Tackle.-I cannot attempt within the limits of this chapter any exhaustive treatise on all the fishing tackle used in salt water, but I think I can lay down the general principles on which it has been adapted from that used in our rivers and lakes. The great feature of recent years has been the popularising of the rod, in preference to the older handline, the method adopted (and rightly so, since it often saves both time and fish) by those who fish not for sport but for silver. And, as a still further advance in the artistic style, lighter rods are gradually superseding the unnecessarily heavy patterns that were in favour ten or fifteen years ago, when sea-angling began to come into its own in the public favour. The golden rule is not to use a heavier rod than necessary. The lighter weapon may take twice as long to do its work, but it may give thrice the pleasure. I am not advocating a cat-and-mouse policy. Each fish should be got into the boat as soon as it is tired out, and to prolong the agony is not only unnecessarily cruel, but also entails the risk of the hook coming away. There is, I believe, a recognised time 
schedule for the killing of salmon, so many minutes to the pound, and the same sort of principle should rule in the capture of sea-fish. But a rod should be a rod, not a billiard cue or clothes-prop. Even tarpon are being caught now on light Japanese rods, such as I used in California, though when I caught tarpon in Florida, four years ago, only very stout rods were in favour. The kind of rod usually sold for catching sea-trout, about I I ft. long and fairly whippy, serves me for bass and other fish up to $20 \mathrm{lb}$. For bigger fish than these, something heavier should be used. Treat the rod well; not perhaps as tenderly as a corn, but do not tread on it. It will not, as sometimes advertised, last a lifetime (unless its owner drowns himself before using it), but, with fair play, it may last for years.

In float-fishing, which is a deadly method from piers and rocks, and, in a few cases (as for grey mullet alongside piers)from boats, a rod is absolutely necessary, as also for any kind of $f y$, or bait, casting. There are a few cases, however, in which I would still advocate the handline, even for sport. One of these is undoubtedly the case of conger-fishing at night, an amusement in which a rod is out of place and will probably be smashed if the conger run large. Then, again, when fishing for lythe or even mackerel from a boat going fast under sail, the strain is too great for a rod, and a handline (or two, one used in either hand, with wooden toggles to prevent the line cutting the fingers) is far more workmanlike. But whatever sort of rod be used, 
do not expect more of it than it is prepared to give, and do not use it as a boathook, to punt with, or to push off from the pier.

Much the same advice applies to the line. Use it as fine as is compatible with saving the fish. It is wonderful how fine a line will save a big fish if properly used.

The link between rod and line is the reel, and a reel may cost anything from five shillings to as many pounds. Indeed, I have given nine pounds for an American sea reel before now ; but you have to pay on the grand scale for everything in America. A good, useful reel for sea-fishing, of the so-called Nottingham pattern, with optional check action, may be had for a sovereign in wood or about twice as much in vulcanite. The latter material has the advantage of lightness; nor does it, like wood, swell after immersion in salt water. On the other hand, it is brittle stuff and apt to smash if dropped on a hard surface. The check, or, as Americans call it, "click" action is designed to put a greater strain on the fish. The same effect may be obtained with a silent brake, which takes longer to wear out; but many fishermen love the sound of the check, and will have it on the reel at all costs. All the same the angler with no soul for any music but the scream of a winch is a poor creature. The great thing about the sea reel is that it shall carry plenty of line. Here is no question of thirty or forty yards of fine line for brook trout, but a good hundred or hundred and fifty yards to hold 
fish which may tear off hall that length before their first rush can be checked. A multiplying gear is also a labour-saving improvement; that is to say, for every turn given to the handle, the barrel revolves twice or more. Lastly, some sort of line-guard, like that devised by "John Bickerdyke," is a desirable preventive of overrunning, that most fruitful cause of disaster at critical moments.

The rest of the tackle, the various combinations of gut, hooks, and lead, must be dictated by a commonsense consideration of the habits of the fish and the kind of ground you are fishing on. By this I mean that there are obviously some tackles which, though safe to use on a smooth, sandy bottom, would be certain to get foul of rocks. When fishing near the surface for lythe, saithe, or bass, little or no lead is wanted. In bottom-fishing a heavy weight is sometimes required, and when the tides run very strong, and this lead has to be one or two pounds, a handline is preferable to the rod. At the same time it should be borne in mind that the finer the line, the less the lead required to take it to the bottom. Gut, single or otherwise, is much used in sea-fishing in the new style. In Turkey, where the water is very clear, and the sunshine exceedingly bright, one has to use twenty or thirty feet of single salmon gut, as the bass will not look at anything stouter; but in our thicker water and duller weather at home I usually find nine or ten feet ample. An occasional brass swivel, particularly where the gut is attached to 
the reel line, will be found useful, and is absolutely necessary when the bait is being towed astern of the boat, as the gut would otherwise get irretrievably twisted up. When after small fish, such as pout or whiting, three or four hooks may be used, but for bass and pollack a single large hook gives the best results, as not only are the big fish more wary, and more likely to be scared by a second hook, but success might be as disastrous as failure, for two lusty pollack on the rod at the same time would be a bad job for the rod.

The "sundries" which make up the angler's furniturehavebeen well memorised in Mr. Malloch's chapter. Tackle and bait (particularly liquid bait for master and men) are not likely to be forgotten, but a dozen odds and ends suggest themselves as obvious adjuncts to comfort and safety. The special case of fishing in small boats some distance from land demands a few items that were outside Mr. Malloch's scope. The weather or temperature may change with suddenness, and waterproofs, or other protection against wet and cold, should not be overlooked. A change of wind may necessitate a long beat back to port, and as darkness or fog may in the meantime fall over sea and land, a lamp should be carried, and some means of signalling in case of distress is also desirable where there is any chance of being run down, either coloured lights (Roman candles serve admirably) or a heavy revolver with blank ammunition. Personally, I never go afloat without a little court plaster and boracic lint, as weevers and other fish can inflict 
very painful wounds if carelessly handled, and much pain and subsequent mischief may be saved by prompt washing and dressing. In summer-time, too, it should be borne in mind that, even in these latitudes, the seafisherman is continuously exposed to the sun, and a broad-brimmed hat, with protection for the back of the neck, is a precaution that should not be neglected, while tinted spectacles will be found a welcome protection for the eyes against the glare off the water.

(3) The Bait.-The right bait is even more important than the right tackle, though the best promise of success lies in a combination of the two. A few fish, like pollack and mackerel, will occasionally seize almost any bait that is drawn across their noses, but as a rule not only has every fish its own particular fancy, but a bait which is deadly for, say, a bass at one seaside resort, would not necessarily tempt the same fish a dozen miles farther up or down the coast. Grey mullet resemble the bass in this curious variety of their appetite in different localities. Thus these fish are caught on paste at Margate, but at Littlehampton, in the neighbouring county, they must have ragworms. As a matter of fact, the list of baits used in the sea is a very long one, and something suitable is generally to be had, because, we must remember, the right bait is, after all, only what the fish you are after feeds on in the neighbourhood. Occasionally, it is true, the visiting angler springs a surprise on them with success. I remember a man, years ago, making a great catch of bass and 
other fish at Littlehampton, wading out in the surf and casting his bait, of which no one learnt the secret, just beyond the waves. Speaking generally, however, it is the local bait which answers best. Thus, to take the case of the bass. In estuaries, like that of the Devonshire Teign, beside which I am at present living, where these fish chase the sandeels over the bar, no other bait is so deadly as a living sandeel. In Cornwall, on the other hand, where the big bass are scavengers, nosing among the weed for refuse from the pilchard boats, a dead pilchard is the best bait, and they do not object if it is a few days old. Elsewhere, again, the baits differ : at Felixstowe, ragworms or artificial bait ; at Ramsgate, mackerel; at Aldeburgh, a phantom minnow; at Barmouth, a bait made with plaice skin; at Padstow, green crab; at Tenby, ray's liver. Such are a few of the offerings which lure this fish on different parts of the coast.

It must be admitted that the bass is an exception. Most other fish have one universal bait that is best, wherever they are caught.

Mussels or sandworms are good bait for cod, flatfish, whiting, and mackerel, when the last-named are feeding at the bottom.

Pieces of fresh herring or mackerel will catch cod, whiting, mackerel, and gurnard.

Squid and cuttlefish are perhaps the best bait for conger.

Ragworms (which are distinct from lugworms, being 
found in the soft mud of harbours and estuaries, whereas lugworms bury in the hard sand along open coasts) or paste are the baits for grey mullet.

Soft crab (i.e. shore crabs that have cast their shell) will catch bass, cod, and other kinds of fish.

By way of experiment, mussels or sandworms may always be tried in a locality where you are not certain of what will be caught. If fish baits are used, herring, pilchard, or mackerel should be cut up in preference to others, as they are oily and silvery, both attractive features in a bait. Whiting and flatfish are next to useless, though I have known a bait of gurnard, with the skin left on, successful at times. Shrimps and prawns, used alive, are also deadly baits for bass and pollack.

Next to knowing the right kind of bait comes a knowledge of how to use it, and here there is some latitude, though there is in most cases a way that is better than the rest.

Mussels, one of the best of all-round sea baits, are not easy to keep on the hook. The difficulty is sometimes got over byscalding them, but this process, though it hardens them, undoubtedly makes them unnatural and less attractive. With a little practice, moreover, first passing the hook through the small piece of gristle, and then, after a turn or two through the soft parts, bringing it out at the "tongue," mussels may be made to stick on the hook, though few baits are easier for the fish to remove without getting caught.

Baiting with wormsis too familiar toneed description. 
Herrings and mackerel should be cut in strips diagonally, the bone removed and the hook being passed twice through the flesh.

Squid and cuttlefish must be washed and hammered until soft.

Living sandeels are hooked through the lower lip, the point of the hook being then lightly passed through the skin of the throat. Live shrimps and prawns may be hooked through the tail. Turkish and Greek fishermen use a very attractive bunch of five or six.

(4) Hints on Catching and Playing Fish.-Here, again, severe condensation will be necessary, and all that can be attempted is the enunciation of broad principles. The ordinary process of holding the rod and either watching a float or the top of the rod and striking at the right moment is a question of knowledge or practice. When using light tackle with large fish, due regard mustbe had to theirbehaviour when hooked. Thus bass often make a last rush, as spirited as any that went before, on catching sight of the gaff or landingnet, and if the angler does not know this he is very apt to lose many a good fish close alongside the boat. Pollack make a determined rush for the bottom, where they hope to cut the line against their native rocks. Short of exceeding the breaking strain of the tackle, every effort must be made to keep them clear of the rocks, or you may come to the parting of the ways. Mackerel sheer wildly to right and left, frequently dashing under the boat's keel, and, if played on fine 
gut, need much humouring. The right time to lift the mackerel into the net or over the side of the boat is at the moment when its head points towards you. Any attempt to coerce it when it has its shoulder to the line will, more probably than not, end in disaster. Conger must be bullied into submission. On them the arts of give and take are thrown away, and the new diplomacy answers best. Should a John Dory be hooked on a smaller fish, as previously described, it should be coaxed very carefully over the landing-net or gaff, as it has probably not taken very firm hold and sometimes relinquishes its grip just when victory seems certain. Grey mullet are tender in the mouth, and, unless played very cautiously, are apt to get away with a torn lip. As in fresh water, some fish are more apt to hook themselves, without the angler troubling to strike, than others. Skate, flatfish, and gurnards do so, but, on the other hand, whiting, pout, and bream need prompt striking the moment a bite is felt. For the gillie's information it may be mentioned that gaffing a lively bass or conger from a small boat in a dancing sea is not quite the same thing as gaffing a salmon from the banks of the Tweed, and I wager that even my friend Bob Muckle, of Tweedside fame, might make a mistake in a yacht's dinghy. If the angler knows what he wants, the gillie may just do as he is told. Then, if a good fish is lost, he is not to blame. (He will probably be blamed all the same, but that need not upset him.)

To revert for a moment to playing the fish, much 
depends on the extent to which the fisherman can trust his rod and tackle. If he is confident of every inch of it (always remembering that it is the weakest spot that lets him down), then he may play the fish firmly to the gaff. I have played a tarpon of nearly i $50 \mathrm{lb}$. to the gaff with more confidence, and in less time, than a bass of $\mathrm{i} 7 \mathrm{lb}$., because in the first case I knew perfectly well that I could take liberties, since it would take a suffragette on polling day to break away from tarpon tackle. As has already been indicated, the fish should be brought to the gaff as soon as possible, short of hauling it as if the rod were a derrick. I have known fishermen so addicted to the music of the reel that, as soon as a fish is hooked, they swing back the top of the rod, so as to pull more line off the reel. Sometimes, owing to difficulty in winding up the slack, the fish is lost, and then I rejoice to see such folly pay the price. With heavy fish and stout tackle, the most effective way of reeling in the fish is by what the Americans call "pumping," the top of the rod being lowered and raised alternately, and the slack reeled in as often as possible. The novice should keep the top of the rod well up, always (particularly when a big fish is hooked in deep water) with due regard to the strain it will bear and the curve it will take without snapping. The quick gaffing of a fish depends not only on the skill of the gillie, but also on the manner in which the fisherman brings his fish to the gaff. If he should get excited at the critical moment, and either slack the line or lift 26 
the fish out of water, an error which will surely goad it to another dash for liberty, then the gaff, however expertly handled, is likely to be baulked of its prey. Needless to say, it is easier to play a big fish when the boat is not anchored, for it then follows the fish, and the strain on the rod is much reduced. The most difficult case of all is when fishing from a high pier, fifteen or twenty feet above the water. Unless the fish can be gaffed or netted by a gillie in a boat, or on a lower step, or unless, as an alternative, the fish can be coaxed to the beach (this depends on the architecture of the pier), practically the only way of saving it is first to tire it out and then to lay the rod down and warily haul it by the line, hand over hand. A single kick while a heavy fish is in the air will probably break the line. The difficulty of playing a big fish from piers is aggravated by the posts and chains round which, in its struggles, it may wind the line. Nor is it lessened by the crowd of idlers who usually gather round in the summer season, not caring whether they give the fisherman elbow room, but imbued with the one idea of getting as good a view as possible of the proceedings. Indeed, luck counts for more in pier-fishing than in any other branch of angling.

The gillie will be held responsible for the boat, and, whether it be a dinghy or a cutter, everything should be shipshape. There is, or should be, a place for all things, and they should not be put just anywhere, but in that place. Nothing is more irritating than to find the bait, possibly a box of writhing worms, where the 
lunch ought to be, nor is there any comfort in sitting on a heap of loose hooks. The bait-knife should be kept in one spot when not in use, and so placed that the fisherman, reaching out for it, encounters the handle, not the open blade. All ropes and sails should be piled neatly out of the way when fishing at anchor, as, if the sportsman should trip over a footboard or bit of ballast just as he is playing a good lythe, there is no telling what he might say or do next. The boat should be kept as dry as possible, as it is no pleasure to sit in a puddle, or to fall over slippery boards. The fish, large and small alike, should be kept in a basket if the boat is unprovided with a well for the purpose. Dead fish floating about the bottom of a boat between one's boots are simply disgusting, and enough to make a man seasick on the spot. Each fish should be knocked on the head when removed from the hook. I am not one of those who telegraph to the editor of the Times whenever they suspect an eel in a fishmonger's shop of suffering from a headache, but needless cruelty is always reprehensible. Incidentally, too, this improves the fish for the table, as, if allowed to die slowly, they are apt to injure and bruise themselves.

Sport at Various Resorts. - Local knowledge is of first importance in all fishing. This is illustrated time and again by the small village urchins who catch more trout with a withy and bent pin than the visitor armed with all the latest temptations from the tackle shop. So, too, in the sea; you may be using the right tackle 
and the right bait, but, without some acquaintance, on your own part or your gillie's, of local conditions, such success as you may have will be a mere matter of luck, and there are places, indeed, where, without the exact bearings of the fishing-grounds, you might as well hang your baits from the cross of St. Paul's Cathedral, for all the fish you are likely to catch. There are, it will be realised, two kinds of local knowledge : the broader knowledge of what fish are taken in the neighbourhood and what bait they like best ; and the more specific, equally necessary, acquaintance with the marks or bearings of the different fishing-grounds. These have to be taken with reference to sundry conspicuous objects on land: a tree on a hilltop, a chine, a coastguard station, a church steeple are all favourite objects because sufficiently permanent to serve. They have come into use by oral tradition. In prehistoric times some old fisherman of the place anchored by chance on a spot where he had a great catch of pollack or whiting, and he immediately took his bearings so that he could come again next day. In course of time he would make his son free of the secret, or it would leak out somehow. New grounds are continually being discovered, and the greatest pains taken to keep the knowledge. I have been fishing on such a mark, which may be known only to my own fisherman, and as soon as another boat came in sight, already perhaps a mile away, my man would quietly get up the anchor and let the boat drift about anyhow, while we pretended to be having all the 
sport we wanted. The trick was of course apparent to the practised eye of the spies, who would take their defeat in good part and presently sail away to other grounds.

I cannot, for obvious reasons, set down in this chapter any of the hundreds of marks round the coast, with which thirty years of sea-fishing have made me familiar, but I can at least indicate a few of the resorts, chiefly along the English coast, where the best fish of each kind are to be taken.

Bass, which occur all round Britain, are at their best along the south coast of England, from Land's End to the Forelands. Plymouth, Teignmouth, Sidmouth, Seaton, Weymouth, Selsea, Brighton, Ramsgate, and Margate all give large bass, and at each a different style of fishing is in vogue. On the east coast, Clacton, Felixstowe, and Aldeburgh, and on the west side, Tenby and Barmouth, are also good spots for bassfishing. For the information of yachtsmen, I may add that there is sheltered anchorage in a harbour or estuary at or near most of them, only Selsea, Sidmouth, Seaton, and Clacton being open roads.

Grey Mullet of good weight are taken at Plymouth, Weymouth, and Margate.

Conger are found on almost any rocky ground in the British Isles, but Cornwall and the Bristol Channel, as well as the rough ground round Beachy Head, in Sussex, seem to be their headquarters so far as the south country is concerned. 
Pollack and Coalfish are found on the same grounds as conger, but the coalfish is scarcer as we come south. Very fine coalfish are taken off the Yorkshire coast on the herring-grounds.

Cod and Whiting, which are at their best between October and Christmas, are to be caught from boats wherever there is the mixture of hard and smooth ground to which they are partial. There is, in autumn, good cod-fishing from the piers at Folkestone, Deal, Felixstowe, Clacton, and Great Yarmouth, and from the shore at Lowestoft and among the wykes and scars in the neighbourhood of Scarborough.

Sharks are mostly taken in Cornwall, about ten miles from the land on hot, calm summer days, and the largest dogfish (topes) are found at Herne Bay, in Kent, and Filey, in Yorkshire, where the Brigg, a magnificent natural pier of rocks, offers undoubtedly the finest shore-fishing for mackerel and pollack in these islands.

These are particular cases, and a fuller list, with details, can be found in most of the manuals on the sport. But, by way of general principles, there are certain topographical features associated with particular kinds of fish, which may, in the absence of any local information to the contrary, be fairly expected to occur in the neighbourhood.

The broadest distinction is that between a rocky and sandy coast. Where the foreshore is bold, with cliffs and rocks, the angler may look for lythe and saithe, 
for conger and cod, bream, wrasse, and probably bass. Where, on the contrary, there are no rocks, but a low, sandy beach, he must expect rather flatfish, whiting, gurnards, with, perhaps, bass close inshore.

If there is a harbour or river estuary, bass may certainly be looked for, and probably also grey mullet.

A shingle beach, with deep water close inshore, should give bass on summer evenings, and cod and whiting in winter.

Now and then artificial conditions are responsible for the occurrence of a particular fish. Bass will haunt the neighbourhood of a fish factory, the refuse from which attracts them under unsuitable natural conditions, and the potatoes and other waste thrown over the side of Margate Jetty throughout the crowded summer season of that popular resort must undoubtedly be held accountable for the abnormal abundance of large grey mullet. On the other hand, the disturbance of engineering operations has of late years been detrimental to the once admirable fishing at Dover and elsewhere.

Having concluded the practical side of the subject,so far as is manageable in the space, I want to say a word of the birds and beasts which are the constant companion of the sea-fisherman in the happy hours he spends on the water. Every angler should be something of a naturalist, not limiting his nature study to the habits of the fish he wants to catch, or of the baits with which he hopes to catch them, but also watching the creatures of the water or waterside which have no 
direct influence on his sport. When Dr. John Brown wrote of Struan Robertson, "Like all true sportsmen, he was a naturalist," he enunciated something better than a half-truth. There is, no doubt, something enviable in mechanical perfection, whether in throwing a fly or pointing a gun, but it is less enviable in the man with no eye or ear for the wonders of nature, and, be he never so successful as a fisherman, he is no complete angler in the best sense of the word. The finest passages of Walton's classic, the passages which have lived, are not those which tell how to put a worm on a hook. There was something, surely, about the music of the nightingale that is treasured by many who never wetted a line.

For the sea-fisherman, who is visited by neither the gorgeous kingfisher nor the sombre heron, the most friendly birds are the gulls, familiar in every marine scene, whether circling in the eye of the storm or paddling in the tidal harbour. No one should shoot gulls. In the first place, they offer such easy shots that none but a duffer could miss them. Secondly, save in very exceptional circumstances (when too attentive, for instance, to the nurseries of young trout), they do no harm. Indeed, they are useful birds in their way, keeping many a harbour clean that would, but for their services, be a hotbed of typhoid, and, in foggy weather, warning the fishermen off the rocks, just as, in fine, they often show them where the fish are. Thirdly, these birds, so beautiful in life, are useless when shot. 
I am aware that there are lasses who stick them in their hats. Why, if the face underneath the hat is comely, it needs no such advertisement; and if it is of the other kind, the less attention drawn to it the better! Occasionally, particularly in northern waters, a large dark bird is seen among the gulls, generally the centre of a commotion. This is a skua, a robber of the air, a pirate of the lochs, which waits till the feebler gulls have picked up a fish, then dashes at them in the air, forcing them to drop their prize, and recovering it before it touches the water. Near Aberdeen the fishermen call them "Dirty Devils," and in Cornwall "Jack Harries," because they harry the gulls.

The shag and cormorant, which do not soar like the gulls, but fly swift and close to the water with outstretched necks, are birds of another feather and dark as sin. They are greedy fellows, eating only living food and therefore useless as scavengers. They are silent fowl, making none of the tumult of the gulls at meal-time, so they are useless as guides to the whereabouts of the shoals. They do not offer easy shots, for they fly fast, dive at the flash of the gun, and carry away almost as much shot as an elephant. Wherefore, I have no hesitation in saying shoot them whenever so inclined, for there is no danger of exterminating the species. They are terrible enemies to a trout stream, once they find it out, and he who would blame a keeper for shooting them would blame the man for saying his prayers. Their bright green eye is full of evil. 
When swimming, they leave only the head exposed, offering a very difficult shot. Shags nest only in the cliffs, I think, but cormorants also choose sites in trees or on the ground, especially on lonely islands where they are free from interference. A first cousin to them, but as different, when seen on the wing, as a bird of paradise from a turkey, is the beautiful gannet, or solan goose, a great white bird, with black bars across its wings. The gannet fishes in a manner peculiarly its own. Soaring a couple of hundred feet above the sea, it keeps a sharp look-out for fish, and I have watched it through binoculars and seen the bill turn from one side to the other as the eyes ranged over the preserves far below. Then, catching sight of a gleam of silver, it suddenly folds its wings and drops, literally like a bolt from the blue, doubtless stunning numbers of fish with the impact, and then swallowing them at leisure. The bird is spared the discomfort which such high diving might otherwise cause it, by the structure of its nostrils, which are covered up by the skin, so that it breathes only through its mouth.

The other birds with which the observant sea-fishermangrowsfamiliar are of smallercalibre-puffins, guillemots, razorbills, and shearwaters-and, if not molested, these soon grow so friendly that they paddle round his boat and dive for such small fish or scraps as he may from time to time throw to them. Detailed description of these small fowl, which are black above and white beneath, may be found in any natural history 
book. The puffin may be recognised from the rest by its parrot-like beak, which, in the courting days, assumes half the colours of the solar spectrum. They are all divers, except the shearwaters, which fly in great curves over the sea and never seem to rest. That they remain so plentiful is remarkable, as they lay only a single egg, but they are careful to lay it on an inaccessible ledge in the cliffs, and, after all, few people shoot them. The only other little bird in the sea-fisherman's visiting-list is the least of the petrels, the little white fellow known as Mother Carey's Chicken (who Mother Carey was, I have not the faintest notion), or the Stormy Petrel, and generally recognised by sailors as the forerunner of bad weather at sea.

Sooner or later the fisherman with a turn for natural history is sure to be attracted by those marine mammals, which we term variously whales, porpoises, and dolphins. Of seals, which are carnivorous animals of a higher order, he may also see something, particularly in the sea lochs of the west coast. I recollect watching one basking on a flat rock in Loch Etive. But they have practically vanished from southern England, and are no longer seen, save at long intervals, even in the wilder scenery of Cornwall and its island satellites, where they once were numerous. The whales and porpoises, on the other hand, are encountered all round these islands. Great herds of the larger whales are uncommon south of Orkney and Shetland, but I have seen the grampus fishing close to land, rushing through 
a shoal of pilchards or herrings, open-mouthed, with a noise like the blasting of a quarry. These whales and porpoises are not fish, for they breathe air, like ourselves, with lungs, and have neither the gills nor scales of fishes. The young are born like calves and nourished with the mother's milk. These animals have, in fact, nothing in common with fishes beyond their watery home and a somewhat superficial resemblance. If, however, the two are closely compared, the differences are immediately evident. The tail of a fish, for instance, is set vertical. The only fish I ever saw with the tail horizontal (as in whales and porpoises) was a shark in the museum kept at Yildiz Kiosk by Abdul Hamid when Sultan of Turkey. Then, again, these whales and porpoises have a blowhole on the head, not found in fishes, and it is through this that the great whales send up that cloud of condensing vapour which, mistaking it for a column of water, folk at sea describe as spouting.

It must at one time or another have occurred to most sea-anglers that, if these could only be induced to take a bait, the smaller porpoises (of, say, $50 \mathrm{lb}$. or thereabouts) would give exciting sport on tarpon tackle. No doubt they would. The difficulty is to persuade them to oblige. During the last twenty years I must have received scores of inquiries on the subject, but I never yet succeeded in solving the problem to my own, or anyone's, satisfaction. He who does so will confer a boon, though not on the porpoises. 
NOTES 
NOTES 


\section{CHAPTER XXII}

\section{Fish Hatching on a Modest Scale}

\section{By HENRY LAMOND}

In these days of intensive cultivation it is more than probable that a gamekeeper or fishing gillie will find it of advantage to be more or less familiar with the art of pisciculture. Given that knowledge of nature solidly based upon a study of the ways and wiles of bird, beast, and fish, which this class of employee already possesses, little more is required in addition except care, scrupulous cleanliness, and sound common sense to turn even an ordinary gillie into a competent hatchery manager. It is proposed to indicate in this chapter the little more that is required.

It is possible that even the employer's attention may be actively turned to the subject when he learns that there is no particular mystery about the business ; that, given suitable conditions, a small hatchery is neither a troublesome nor a costly undertaking either to construct or to maintain ; and that, again given suitable conditions, some real return may be expected from the outlay incurred. It may be of service, therefore, to give a description of a hatchery which has been in active 
operation for several years, and which has had an annual output of nearly 300,000 healthy fry of trout, sea-trout, and salmon. To assist the practical man as far as possible, a sketch plan of the hatchery, a specification and estimate of cost, and other particulars are appended.

There is no occasion at this time of day to refer to the practical benefits which may be obtained from artificial trout-hatching. Nor are we concerned to defend the practice of salmon and sea-trout hatching, the necessity for which, in our opinion, depends solely upon local conditions. At Luss, on Loch Lomond, it has been found from practical experience that the available natural spawning-ground is so deficient and the streams themselves are so obstructed, that a hatchery forms a valuable supplement of nature. There is really nothing artificial involved in the process. The ova collected are simply placed in security. There are many small sea-trout streams in the Highlands, especially on the west coast, where similar conditions prevail, and for these a hatchery would be similarly valuable. Proprietors, moreover, need have the less hesitation in hatching sea-trout for this reason, that the sea-trout does not roam far afield, as does the salmon, but is essentially an estuary fish. A large proportion of Loch Lomond fish, marked when spawning in the tributaries, have been recaptured the following season spawning again in the same tributaries. To the hatching of seatrout, then, as well as trout, attention may be usefully directed. 
Now, what are the essential requisites of a hatchery? Obviously land and water, the first if possible conveniently close to the dwelling of the prospective hatchery manager, and the second ample. There are few estates, we imagine, where a combination of circumstances of this kind will not be found. For the site itself, any gently sloping plot of ground upon which a wooden house, $20 \mathrm{ft}$. square, can be erected will do. If the subsoil is porous so much the better, but if not, a gravel foundation can easily be provided. The water supply is a more important consideration. It must be ample, pure, and not liable to the slightest risk of interruption, for any cessation of the flow at a critical juncture would be disastrous. For these reasons the water supply available will determine the site.

If it is impossible to secure, as has been secured at Luss, with the kind permission of the proprietor of the estate, connection with an existing domestic water supply, then a stream must be looked for where a sufficient head of water can be obtained. At Luss, delivery is made by a $\frac{1}{2}$ in. lead pipe, but the head of water in each case will determine the diameter of the pipe necessary to deliver the quantity of water requisite. This, roughly speaking, must be sufficient to give to each hatching box a complete interchange of water every three minutes. In a convenient stream, then, a natural pool must be looked for giving a fall of at least $30 \mathrm{ft}$. to the proposed hatchery. If, however, no such pool can be found, a small dam can easily and cheaply 
be engineered to form one. In the pool so found, or formed, a small covered chamber should be constructed, guarded at the intake by an iron grating to exclude flotsam. From within this chamber the main water pipe, further protected by a rose, will be led to the hatchery. If the water can first be filtered through an outer chamber of gravel,additional security will be given against danger from the deposited sediment of "spate" water. The pipe will terminate within the hatchery itself, which we are now in a position to describe.

The hatchery, then, is a simple wooden structure, $20 \mathrm{ft}$. long by $\mathrm{I} 7 \mathrm{ft}$. broad, standing on a sloping gravel foundation. The back wall is $7 \mathrm{ft}$. and the front wall I I ft. 4 in. in height, giving the lean-to roof, which is covered with patent roofing felt, sufficient slope from front to rear to throw off the rainfall. The whole structure is thoroughly tarred over. As direct sunlight, or indeed a strong light, is detrimental to the ova, the house faces away from the south, and in this front wall alone are the door and three small fixed windows, one being over the door and one on each side. These windows are obscured by green cloth roller blinds.

The walls, of ordinary white pine, are built double, and the spaces between the standards are filled in with sawdust to preserve an even temperature.

The floor space, sloping towards the front door, is occupied by eleven hatching boxes, which, as the plan shows, are arranged to allow of convenient working. 
Against the left wall are two boxes end to end. Two groups of four boxes each, arranged end to end in pairs, occupy the central floor space, while against the right wall away from the door is one box. The space left on this side near the door is useful for tackle. The boxes stand on frames at a convenient height from the floor, and as at Luss the water supply enters from the rear, the tier of six boxes farthest from the door is on a higher level by the depth of a box than the tier of five nearest it, each upper box draining into the one set beneath. At Luss the six higher level boxes are fitted with glass grilles for carrying the ova, while the four central boxes of the lower tier are fitted with perforated zinc baskets.

To trace the water system more precisely, the supply is delivered from a continuation of the main $\frac{1}{2}$ in. lead pipe within the hatchery to each of the six upper boxes. Separate connections with this pipe are made for each box, the taps being finished with $\frac{5}{8}$ in. nosecocks; after serving the upper boxes the water flows over lipped slots to the lower tier, whence each box drains to a common lead waste pipe carried beneath the flooring through the doorway to a fireclay drain pipe leading to the river a few paces away. The supply of the lower tier of central boxes is, by a separate connection with the main inside the hatchery, supplemented by block tin tubes fixed inside the boxes perforated with needle points about one half-inch apart. The tubes are carried round the upper inner edges of 
each box, and stop-cocks control the supply for each box. When the water is turned on it is thrown from each pipe to the opposite row of baskets in the box, for
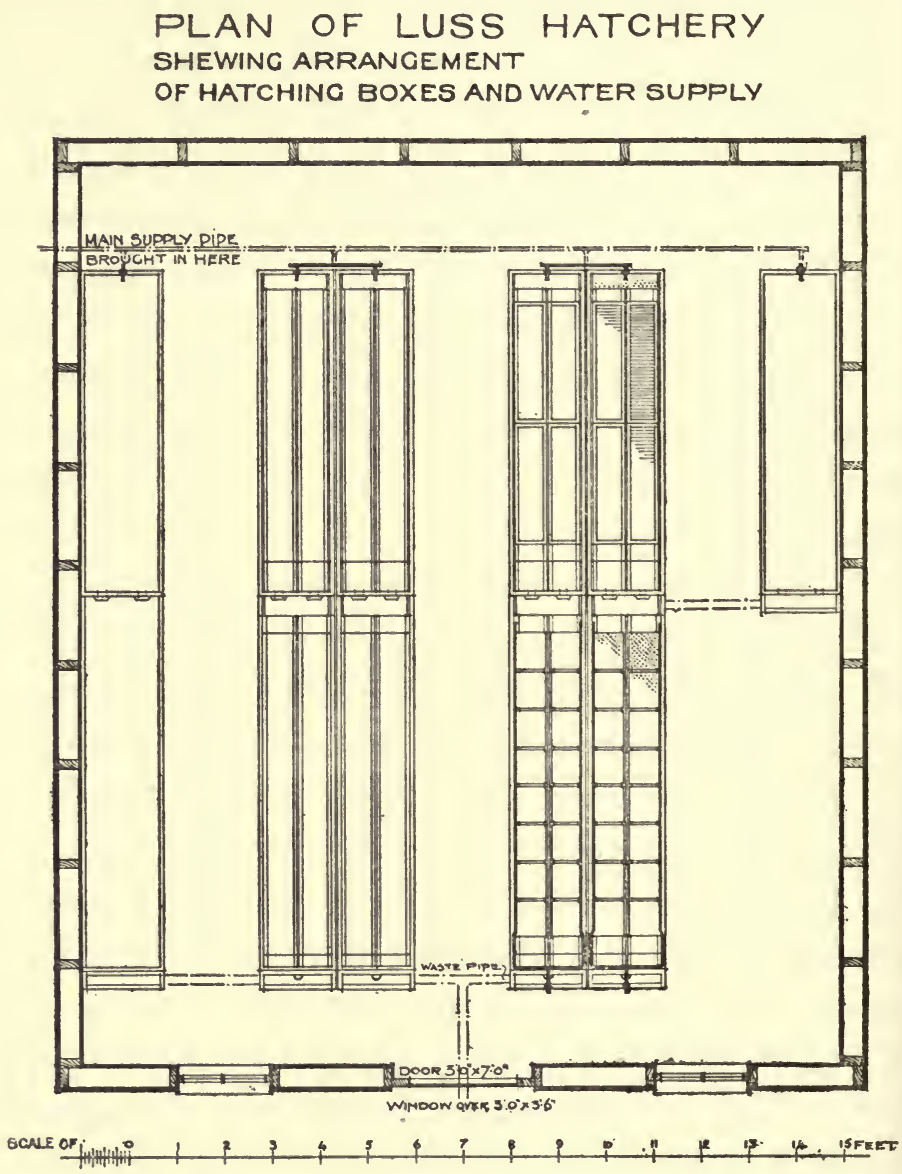

its whole length, practically like a spray bath. This supplemental supply ensures to the ova massed in the baskets a sufficiency of oxygen of which the water flow- 
ing over the eggs of the upper tier has been already partially depleted. The whole water-supply system permits of each box being worked as an independent unit. At Luss a cistern and filter within the hatchery were installed and abandoned, as sufficient pressure from these could not be obtained from the delivery pipe to give the flow of water requisite.

It will be sufficient now to describe one of the hatching boxes arranged for the glass grille system of hatching, and one fitted with the perforated zinc baskets. To take the former first. The glass grille system is the most effective for hatching out ova. It shows a slightly lower percentage of loss than the basket system, but its practical drawback is that it requires more space in proportion to the number of ova hatched. The hatching box is made of $\mathrm{I} \frac{1}{8}$ in. dressed deal carefully charred inside. It is $6 \mathrm{ft} .9$ in. in length, I ft. 7 in. broad, and $7 \frac{1}{4}$ in. deep outside measurements. It has wooden ledges on each side of the bottom, and a removable wooden runner in the centre placed longitudinally. On these rest the four frames carrying the glass grilles. The grille upon which the ova rest is a series of glass tubes, each tube being $6 \frac{3}{8} \mathrm{in}$. long and $\frac{1}{4}$ in. in diameter. The tubes are set in a row close together, but not touching, across each frame, and are kept in position by serrated wood or zinc strips fixed to the inside edges of the frame. The level of the frames in the box is so adjusted that the eggs when placed upon the grille are 3 in. from the bottom of the box, giving 
that depth of water beneath them, while the water-level is maintained at half an inch over them. As it is important to strain the water of all sediment, the nose-cock at the upper end of the box discharges first into a perforated zinc strainer, which, with a further inch or two of space before the trays are reached, distributes the inrush of water to the box in a uniform gentle flow. At the lower end of the box a removable perforated zinc screen prevents any egg lapping over into the lower box, and, later, prevents the escape of the alevins and fry when the eggs hatch out.

Between the system of glass grilles and the perforated zinc baskets the only difference in principle is that the eggs on the grilles are laid in uniform rows, while in the baskets they are deposited in mass, perhaps two, perhaps three, layers deep. At Luss two layers deep has been found to produce results equal to the grilles, while hatching double the quantity of ova, that is, the proportion of loss is no greater, the total loss being in both cases from two to three per cent. only. The baskets are carefully made of finely and closely perforated zinc sheets and are 8 in. square and 3 in. deep. Two rows of eight baskets occupy the space in the hatching box, a number sufficient for convenience of working. The whole sixteen baskets rest upon the longitudinal side ledges and central runner already described, at such a level that at least three-quarters of an inch of water will flow freely over three layers of eggs. When it is added that, as in the upper boxes, a strainer 
is placed at the intake and a screen at the outflow, and that these boxes are fed in addition by the spray waterpiping already described, enough has been said to give an idea of both systems. There is only this to be added, that all woodwork must be carefully charred ; that every separate piece must be carefully smoothed and exactly fitting, without the least projection or crevice ; and that all zinc should be varnished by a special varnish, which can be obtained from any of our commercial hatcheries.

Let us assume now that everything in the hatchery is prepared for the reception of the ova. All the taps are in working order, ready to be turned on or off as occasion requires; a steady flow is left running; the escape pipes are clear of obstruction, and the glass grilles (or the baskets) are all in their places submerged to the proper depth. If the weather is specially severe, we have provided a small oil stove to keep the temperature of the house above freezing-point. Candles or stable lamps are also at hand, as the winter day gives brief light to work by.

It had been reported (we shall suppose) that the fish would likely be on the redds that afternoon, and now the dogcart, or, better still, the motor car, is awaiting orders ready to start at a moment's notice, as we have some little distance to travel. Our head man has meantime been putting aboard the vehicle four white enamelled tin basins of 15 in. diameter, a couple of white enamelled tin pails with lids, and two or three kitchen towels, the use of which will immediately appear. Our man has 
donned his salmon waders, as will also have his four or five assistants, who are already on the ground. They have with them the nets which have been kept all day in readiness near the waterside, and they have also a couple of stout poles $6 \mathrm{ft}$. long, not only to beat the water and prod the banks, but to help them to keep their balance in the icy stream.

Arrived at our destination, we are told that several pairs of salmon, or sea-trout, or trout, as the case may be, are on the redds. We see for ourselves the females flashing their sides occasionally in the brown water, and the attendant males dashing every now and then almost ashore on the shallows. The river (we shall suppose) is some fifteen or twenty paces wide, gravelly runs alternating with slacker places, scarcely pools, of from 2 to $4 \mathrm{ft}$. in depth. We select a stretch of water where there are several pairs of fish, and at the lower end of this, at a point where the river narrows, we fix our principal net.

This is a large bag-net of a 4 in. mesh, neither floated with corks nor leaded, but simply reeved to a circle of rope, the diameter of the mouth being $20 \mathrm{ft}$., and the bag extending $40 \mathrm{ft}$., tapering to a point where, by means of a slip-knot, we can take out any of the enclosed fish that is required. Besides this large net, four smaller bag-nets, Io ft. diameter at the mouth and ro ft. in depth, are useful for catching trout in small burns, and for retaining large fish temporarily till wanted. The large bag-net is now fastened by two guys 
at the water-level, one on each side of the stream, and kept open by two others fixed higher up on opposite banks. The flow of water keeps the bag distended. Meantime the men have entered the water at the head of the spawning stretch, 200 yds. or so upstream, and begin to beat the fish down to the bag-net. Two men follow with a sweep net stretched across the river to prevent fish breaking back, while a third wades behind the centre of this net to lift it over obstacles. Both banks are poked and prodded with the poles to prevent fish taking cover. All the fish in the "drive" fall back in some little excitement, till at last they find themselves within the bag-net.

A ripe female is selected, taken from the tail of the net, and handed to the chief operator, who, all his appliances ready, is waiting to strip her. He takes the fish, wraps one of the towels round her to prevent her slipping, leaving the vent clear. Then, sitting down, with a clean, drybasin between his feet, he holds the fish, head towards him, tail outwards, and bellydown, with the vent over the basin. If the fish is perfectly "ripe," a slight pressure will cause the ova to fall into the basin. If not, a repeated gentle pressure from the throat towards the vent will bring it away. When all the ova are extracted, the fish, if carefully handled, will swim off little the worse for her adventure.

One of the males in the bag-net has meantime been selected to perform his part of the ceremony. $\mathrm{He}$ is taken, then, wrapped in the towel, and held exactly as 
was the female, while his milt is allowed to run over the eggs in the basin. A slight pressure near the vent is necessary to start the flow of milt. A very few drops is sufficient to fertilise the mass, and one male will fertilise the ova of several females. But it is poor economy to be niggardly if males are plentiful, and, on the other hand, to be extravagant if males are few. In any case it is good policy to retain all superfluous males until the day's work is over. Hence the practical utility of the small bag-nets. After depositing the milt on the eggs, which at this stage are all separate, the operator stirs them gently with the tail of the male fish. He in turn is then liberated, or kept captive for further service if required. The eggs are then covered with water an inch deep over them, and in a few minutes another quarter of an inch of water is added. The eggs meantime have coagulated in mass. Then the basin must be left perfectlystill for a time, which maybe anything from twenty minutes to two hours, according to temperature. During this time the mass will be disintegrating, and any disturbance must be avoided. Now and again the operator may look carefully to see if the eggs are separated, when, if they are, the process of fertilisation is over and they may be washed clean of milt by gently pouring water over them. When they are quite clean, the eggs will be found to have changed their former rich salmon-pink to an opalescent hue, which indicates that fertilisation is complete. The same procedure is gone through with other fish, and as each lot of ova is fertilised and cleaned 
it is placed in water in the covered pails, not mixing the ova of sea-trout and trout, say, indiscriminately, but using separate pails for the ova of each species of fish stripped. When enough ova has been collected, or all we can get on this occasion, we re-enter our conveyance and make for the hatchery with it.

It may be said at this point that the whole operation in principle is the same for salmon, sea-trout, and trout, but as salmon spawn when the weather is as a rule very cold, their eggs take longer to fertilise than do those of trout or sea-trout. A female salmon in most books is credited with providing one thousand eggs for each pound of her weight. This is probably an overestimate, but the figure gives a rough indication of the total quantity of ova obtained. An average sea-trout or trout provides about eight hundred eggs for each pound of weight. In the operations described there is not the slightest difficulty, except that it is sometimes not easy to get a ripe male at the same time as a ripe female, and a male may require to be floated with the party down or upstream in the small bag-net. Sometimes, too, darkness descends on the scene and the work has to be done by lantern light, while frost always protracts the work. The great matter is to have one person in sole command, whose duty it will be to see that everything is done systematically and rapidly, not in a flurry and hurry.

Arrived safely at the hatchery the ova has now to be deposited on the grilles or in the zinc baskets. This 
requires some neatness and care, an enamelled cup may be used to ladle out the eggs from the pails. If we are working with glass grilles, no more ova must be placed on each frame than will occupy exactly the available space. Each little rack must contain its exact quota of eggs, so that when the frames are filled all the eggs will be uniform in rows, and all the rows uniform in the box, with half an inch of water passing gently over them. If we are using the perforated zinc baskets, each may safely be filled with two or three layers deep of ova in mass, but at least three-quarters of an inch of water in this case must flow over the eggs. In these boxes, too, the auxiliary sprays will now be carefully turned on so that each jet falls into the centre of the opposite basket in the box. Everything being now in order, water taps all flowing freely, and all tackle put away, the house may safely be locked up for the night, for the labours of the day are satisfactorily ended.

In water with a temperature varying from $40^{\circ}$ to $45^{\circ} \mathrm{F}$. about the thirtieth day the eyes of the embryo fish may be seen, two little dark specks in the substance of the egg. Trout may be expected to hatch out in about seventy days altogether with water at the above temperature, sea-trout in about ninety days, and salmon in about one hundred and twenty days. All these periods will be protracted in proportion as the weather is colder, so that no anxiety need be feltat delay in hatching. Throughout this period of incubation nothing requires to be done but to keep the water constantly 
flowing and to maintain a careful watch upon the ova, for which purpose the hatchery will be visited daily. A few matters of some practical importance may be referred to as applicable to the present stage.

Stress has been laid upon the advisability of keeping the eggs in exact uniformity on the glass grilles. The reason is that, so arranged, any speck of foreign matter, and any dead or barren or diseased egg, will be detected at a glance, just as a defect of uniform in a soldier will be detected in a regiment drawn up in line. The eggs themselves should never be handled, but arranged and rearranged on their racks with a stiff feather. A small glass syphon tube, one end closed with indiarubber, will suck up, after a pressure of the thumb, any egg for closer examination. If the slightest trace of white fungus is observed upon it, the egg should be at once destroyed, for the fungus growth develops very rapidly if not checked. Careful charring of all wood used in the construction of the boxes, cleanliness of all utensils, and careful examination of the eggs, are the best preventatives.

A thermometer, several syphon tubes, two or three clear glass wineglasses, a tiny gauze landing-net, and a bunch of seagull wing feathers should be always at hand.

The eggs are almost as easily examined in the baskets as on the grilles. All one has to do is to take each basket in turn, raise it an inch or so in the water, and press it down again firmly. The water, rushing in through the perforations, will cause the eggs to boil 
and simmer, and any dead or barren egg, being lighter, will come to the top. It can then be picked out with the syphon tube. So too any foreign substance will show up at once in the mass.

The only occasion for real anxiety at this period is during a spate, when a large proportion of matter held in suspension in the water may be expected to be deposited, if not on the eggs yet in the boxes. Of course the best means to prevent this is careful filtration, first at the source of supply, and again, if convenient, within the hatchery. But, notwithstanding, the boxes will still require occasionally to be cleaned. This can be done without injury to the eggs, but, as great care is necessary in the moving, cleaning with clear water, and replacing them, not to mention the cleaning of the boxes, it is a troublesome enough business. The danger of a deposit on the eggs is that it prevents the free absorption of oxygen from the water through the shell of the egg, and the free giving off of the carbonic acid gas generated by the growth within, resulting in suffocation and death of the embryo.

Periodical inspection should also be made at this time of the intake chamber of the water supply, and the rose of the main pipe examined to see that no floating matter has got in to foul it. Decayed leaves are often troublesome in this respect.

With ordinary care all the eggs will duly hatch out at the appointed time, when our young fish will have reached the alevin stage. 
When the eggs have all hatched into alevins, some little rearrangement of the hatching boxes falls to be made. A few points of management appropriate to the period before the fish becomes a "fry " may also be referred to. When the embryo fish bursts its shell it is not in the least like a fish. To the blunt head, with its staring black eyes, and the thin transparent body, is added an elongated bag larger than the fish, containing sufficient nourishment to last it for a further space of fifty days. The fish is not perfect until this bag, or umbilical sac, is wholly absorbed. During the period of absorption the instinct of the little creature, which can only wriggle spasmodically on its side, drives it to hide in any minute crevice that it can find. Now it is that previous careful smoothing of all angles and exact fitting of all fixed and movable parts of the box will be seen to be of the utmost importance. For into every corner and crevice the alevin will attempt to wriggle, and success, or partial success, will almost certainly have fatal results. The best protection for them at this time, beyond careful construction of the boxes, will be absolute darkness in the hatchery.

In those boxes containing grilles it will be observed that, as the eggs hatch out, the alevins drop through between the glass tubes to the bottom of the box, and the syphon tube will now be in constant use removing the empty egg shells. When the eggs are all hatched, the glass grilles and the frames which carry them are removed, thoroughly cleaned, and carefully put away. 
The hatching box has now become a small rearing pond in which the alevins live comfortably until they are perfect little fry of an inch or an inch and a quarter in length, capable of fending for themselves in the great world of water out of doors. Before they have left the hatching box, even before the sac is wholly absorbed, they may be seen all lying head upstream to the inflowing water, and "rising" now and then inquisitively to some tiny floating speck.

As in the grille boxes so with the baskets. When all the eggs are hatched, the baskets and supporting ledges are taken out, cleaned, and put carefully away. It is convenient to keep all the alevins of one mass of ova in their own basket till the whole box has hatched out.

Not much need be said by way of hint or warning now. Care and cleanliness are still essential. Risks of spate water must still be run and guarded against. But the main thing is to see that the alevins do not find out some new and original method of committing suicide. Hence every joint and junction must be examined in the boxes, and no flaw in the intake or outflow perforated zinc screens must be permitted. So, too, any dead or injured alevins should be removed at once, as should also all "deformities," of which there are always a few. Double-headed and double-tailed fish are perhaps most common, but often two are found joined together at the belly, or actually crossed through each other like the sign of multiplication. 
As we have not contemplated the construction of rearing ponds in connection with our supposed hatchery - a somewhat costly business-things have now reached a stage when two matters of importance have to be considered. The first is, where are the fry to be put? And the second, how are they to be conveyed to the spot? The first of these will, of course, depend upon what kind of waters one has it in mind to stock, and also whether we have been preparing to stock them with sea-trout and salmon, or with trout only. If salmon or sea-trout, or both, we may safely put the fry into any clear, running stream. Wherever there is gravel, running water, and marginal growth, the fry will find both security and food and may safely be left to themselves. Should our stock be trout, the same principles will apply to the restocking of a river. If, however, one is restocking a reservoir or natural loch, local conditions require to be studied. Any small feeders, if such exist, which promise to afford both food and shelter will be the place to put the fry. They will very soon fall back to the main sheet when they require a wider space to range in. But if no feeders are available, the fry must be placed in the loch itself. When this has to be done, a shallow sheltered side of the water should be selected, and instinct will teach the young fish how to protect themselves. Undoubtedly many will fall victims to numerous enemies of all kinds, but their numbers allow considerable margin for casualties. In any event the brood should be from 3 to 4 in. 28 
in length after one year, and from 6 to 8 in. in length in two years if trout and sea-trout. Salmon do not exceed 6 or $6 \frac{1}{4}$ in. in length prior to migration.

As to the carriage of the fry, we have found that they carry most easily and conveniently in large glass wicker-covered carboys, such as are used in chemical works. The carboys should be full of water to prevent jarring in transit, and not crowded to excess with fish. Should there be any risk of delay, or the journey be long, fresh water should occasionally be added. With ordinary luck the whole consignment will safely reach its destination.

We have not overlooked that the hatchery may be stocked with eyed ova purchased from one or other of our well-known hatchery companies. Eyed ova, if carefully packed, stand well the vicissitudes of a long journey. The main points to be observed are that the consigner thoroughly understands the route and the various means of transit between the point of departure and the end of the journey. Van, train, steamer, cart -all may have to be requisitioned before the hatchery is reached, and all should be accurately timed before the consignment begins its travels. There should also be complete understanding by the consignee as to the time of arrival of the ova, so that arrangements may be made for the final stage of the journey, and everything be in readiness at the hatchery. Telegrams ought to pass between the parties intimating and con- 
firming the dispatch of the ova. The further career of the purchased eyed ova from that stage onwards will follow the lines already described in the foregoing pages.

It may be of interest to add that at Luss the only difficulty of collecting ova from salmon, sea-trout, and fario has been caused by untimely floods. In four out of the seven seasons during which the hatchery has been in operation, the ova treated have been supplemented by consignments of eyed ova from Howietoun and the Solway Fisheries Co., at Dumfries, representing approximately 596,000 fario ova. In the seven seasons an approximate total of I,6 I I,000 ova of all species has been treated, of which $1,576,000$ have been reared and distributed as healthy fry.

The whole hatchery arrangements were designed by Mr. Thomas Duff, I.M., Glasgow, a member of the Loch Lomond Angling Improvement Association. Its practical management has been in the competent hands of Mr. Walter M'Diarmid, Luss, from the beginning.

\section{Notes by EDItoR}

The Royal Commission on Pollution of Rivers have made some interesting experiments at Coleburn, Banffshire, with distillery effluent. The operations were conducted under the direction of Mr. Littlefield, with the view to avoid pollution of the river Spey. 
Complete success has crowned the efforts of the experimenter, as salmon ova not only hatched out in the effluent three days earlier than in the Spey water, but the fry grew faster in it than in the ordinary water.

Another discovery worthy of notice is a cheap way to supply feeding to lochs before stocking with trout. To encourage food, place large bundles of bracken, weighted down by large stones, all round margin of loch in two feet of water, and allow it to decompose; this will prove a hatchery and sanctuary for mollusca and all sorts of fresh-water shrimps; a large increase in size of trout will soon be observable.

P. J. M.

COST OF ARTificer's WORK OF Hatchery at LusS.

\section{The Hatchery}

Removing turf and preparing site @ 95 .

2. $5^{\prime \prime} \times 2^{\prime \prime}$ Sawn standards and runners of walls (red pine), 440 lin. ft. @ 2 d. . . . . . . . . 3134

3. 21 Do. stakes in ground under sole runner each 24 " long, to be charred and well tarred, and the runner spiked to do. (1) 5d. . . . . . . . . . . . 089

4. $I_{\frac{1}{8}}^{\prime \prime}$ White pine tongued and grooved flooring in $6 \frac{1}{2}$ breadths, on outside of walls well tarred on outside, 76 sq. yds. @ Is. 9d.

5. $1 \frac{11}{8}$ Beads at angles, 37 lin. ft. @ 2d. . . . . . 06

6. $\frac{5^{\prime \prime}}{8}$ White pine half-checked serking on inside, 68 sq. yds.

@1s. 
Forward $\begin{array}{rrr}£ & \text { s. } & \text { d. } \\ 14 & 18 & 3\end{array}$

7. $6 \frac{1}{2} " \times 2 \frac{1}{2}$ "White pine spars of roof, checked to runners at top and bottom, I62 lin. ft. @ 2d. . . . . I 70

8. $6^{\prime \prime} \times 2^{\prime \prime}$ Do. dwangs betwixt do., 34 lin. ft. @ 2 d. . . $\quad 058$

9. $\frac{5}{8}$ "White pine half-checked serking on do., include doubling fillets at sides, 40 sq. yds. @ Is. . . . 200

Io. Tarred felt on serking in two thicknesses, 40 sq. yds. @ Is. 200

I I. Packing with sawdust space between flooring and serking of walls $5^{\prime \prime}$ thick, 69 sq. yds. @ 3 d.

I2. I $5_{8}^{\prime \prime}$ Fixed sashes with astragals glazed with sheet glass, and

primed and painted, 2 coats (red pine), 26 sq. ft. @ $8 \mathrm{~d}$.

13. $\frac{5}{8}$ " Chamfered checks to do. (-do.- $), 34$ lin. ft. @ $2 \mathrm{~d}$. .

14. $\frac{5 \text { " Bevelled weather plate over sashes (-do. } \rightarrow)}{8}$ lin. ft.

(1) 3d. . . . . . . . . . 020

I5. I $\mathbf{3}^{\prime \prime}$ Framed and lined door (-do.-), 20 sq. ft. @ Is. . I 0 -

16. $\frac{5 \prime \prime}{8}$ Chamfered checks (-do.-), I6 lin. ft. @ 2d. . . 028

17. Do. facings (-do.-), I7 lin. ft. @ 2d. . . . . 02 10

18. I Pair 6" d. j. hinges and screws @ 6d. . . . . 006

19. I Galvanised iron $6^{\prime \prime}$ rim lock with brass mounting and

four keys @ $5 \mathrm{~s} . \quad$. $\quad . \quad$. . . . 050

20. Fitting and hanging and onputting mounting of 1 door

(1) $2 \mathrm{~s}$.

II. Hatching Boxes.-All dovetailed at corners and raggled and jointed with white lead

21. $I_{8}^{1 \prime \prime}$ Dressed deal bottoms of boxes in boards, $6^{\prime} \cdot 9^{\prime \prime} \times 1^{\prime} \cdot 7^{\prime \prime}$,

64 sq. ft. @ 8d. . . . . . . . $\quad$. 228

22. Do. sides and ends of do. 6" deep, 50 sq. ft. @ 8d. . . I I I3 4

23. $2^{\prime \prime} \times 2^{\prime \prime}$ Double checked teak framing of grille sliders,

scalloped on under edge 40 lin. ft. 6 in. @ $8 \mathrm{~d}$. . . . I 70

24. $\frac{3}{4}{ }^{\prime \prime} \times \mathrm{I}^{\prime \prime}$ Plain do. do., $8 \mathrm{I}$ lin. ft. @ Id. . 069

25. I ${ }_{8}^{\prime \prime} \times \mathrm{I}^{\prime \prime}$ Checked teak frame of grilles, 160 lin. $\mathrm{ft}$. @ 2d. • I 68

26. $2 \frac{1}{8} \times \frac{1}{2}$ " Bevelled (pine) fillet at end of box, 9 lin. ft. 6 in.

@ Id. . . . . . . . . . . . 009

27. Fine wire gauze 6 " broad tacked on to box, 9 lin. ft. 6 in.

@ Is. . . . . . . . . . . 096

Note.-Superseded by perforated zinc screen.

28. $3^{\prime \prime} \times 2^{\prime \prime}$ Mill dressed framing under boxes, 162 lin. $\mathrm{ft}$. @ I $\frac{1}{4} \mathrm{~d}$. 0 I6 I0

29. $\frac{7^{\prime \prime}}{8}$ Deal boxes for overflow, I4 sq. ft. 6 in. @ $6 \mathrm{~d}$. • . 073

Forward $£ 32$ I6 II 


\section{$£$ s. d. \\ Forward $£ 32$ I6 iI}

\section{Water Supply}

30. $\frac{1}{2}$ " Lead $7 \mathrm{lb}$. supply pipe and laying in track where required, 66 lin. ft. @ 7 d. . . . . . . . 1186

31. 8 Solder joins of branch supplies @ Is. . . . . 08 o

32. I Brass $\frac{11}{2}$ screw down stop-cock @ 5s. . . . . . 050

33. Io do. $\frac{5^{\prime \prime}}{8}$ do. nose-cocks @ 5s. 6d. . . . 2 I 50

34. Forming connection of lead pipe to $3^{\prime \prime}$ iron pipe, include boring and tapping and brass ferrule @ 17s. 6d. . . 0176

35. $2^{\prime \prime}$ Lead $5 \mathrm{lb}$. waste pipe, include laying in track where required, 6o lin. ft. @ Is. • • • • . . 300

36. 4 Lead flanges in bottom of boxes @ 9d. . . . . $\quad 030$

37. 4" Fireclay drain pipe, include digging track and filling up, 12 lin. yds. @ 2s. . . . . . . . . .

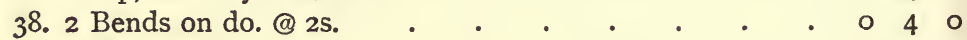

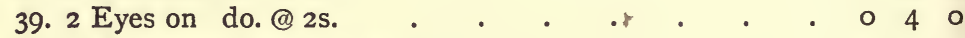

40. I Y. junction piece @ 2s. . . . . . . . . . 020

4I. Connecting drain with lead waste @ 2s.6d. . . . 026

42. Charring timber of boxes. . . . . . . 050

43. Executing all jobbings and removing rubbish at comple-

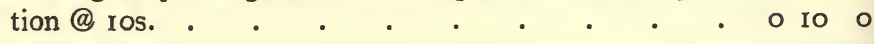

Total Contract Price $£ 44$ I5 5

IV. Glass Grille System

44. 2500 Glass tubes $6 \frac{3 \prime \prime}{8} \times \frac{11}{4}$ (carriage 2s. 6d.) per 100 @ 4s. . $\quad 5 \quad 26$ 45. 1200 Do. do. (carriage 2s.) per $100 @$ 3s. 8d. . $22 \quad 6 \quad$

\section{Basket System}

46. Cost of perforated zinc baskets

Total Original Cost \begin{tabular}{c}
$6 \quad 6 \quad 4$ \\
\hline $58 \quad 10 \quad 3$
\end{tabular}




\section{NOTES}




\section{NOTES}




\section{CHAPTER XXIII}

\section{Miscellaneous Duties}

As supplementary to the many questions that we have discussed throughout this book, we append a few notes on questions of miscellaneous yet very important interest, which lie within the routine work of the keeper.

(I) The very first duty of a keeper on entering a new situation is to ascertain his boundaries and walk round his marches. When he is able to obtain the assistance of the outgoing keeper or of an under-keeper, this is simple enough, but there are often instances where he is unable to do this, and there are occasions when a keeper cannot at the time of his arrival obtain the advice of his master, who may not appear at the shooting till August or September. When the property is very extensive, he will, of course, consult any plan or map of the ground that may exist, and should not hesitate to make inquiries from the farmers and shepherds. It often happens on very large moorland shootings that the new keeper has some difficulty with the outlying beats, and may inadvertently trespass on ground not under his charge. He may, under these 
circumstances, discover his mistake by observing the marks on the sheep, and may note the difference between the ones he knows belong to his own ground, and those which are on the ground on to which he has inadvertently trespassed. The difference in the marks may help to put him right.

(2) Some time before the shooting season the keeper should make a systematic inquiry into the following questions :-

(a) Any necessary assistance in the way of under - keepers, gillies, beaters, and drivers.

(b) The hiring or buying of hill and other ponies and horses, panniers, game bags, cartridge bags, game carts, coop carts, etc. etc.

(c) Dogs, the number required, and if to be hired or bought; their condition and capacity for work. Chains and leashes, condition of kennels, food and bedding, etc.

(d) Ferrets, number required; their condition and capacity for work; presence and condition of living accommodation, food, etc.

(e) Tools.-The proper supply of spades, flags, and sticks for beaters and drivers, flankers, and stops ; the accessories of the gunroomoils, tow, etc.; the keeper's personal tools -e.g. corkscrew, cartridge-extractor, knife, 
matchbox, watch, flask, whistle, and whip.

(f) Baskets, boxes, and labels for game.

$(g)$ Arrangements for selling game.

(h) The keeper's gun and ammunition; condition of fishing-rods, fly-book, hackle case, waders, gaffs, landing-nets, fishing-baskets, and bags.

(i) Licences.

(j) Drugs for horses, dogs, and ferrets.

(k) Cleaning and disinfecting material for stables (where there are no coachman or stable hands), kennels, ferret boxes, and runs.

(l) Boats-oars. Number and condition of repair -boat chains, balers, etc.

(3) The keeper and his underlings must always be on the alert to assist in the following courteous actions -(a) Giving all assistance in their power at luncheon time, for instance by supplying game bags or other forms of seats for the shooters, by putting soda-water bottles into running streams for the purpose of cooling, by opening wine, beer, or whisky bottles, by laying out the contents of the luncheon basket, and by carefully stowing away the débris of the luncheon before the guns start shooting again; (b) holding guns while the sportsmen get over or through dykes, gates, or hedges; (c) procuring waterproofs or any change of clothing which may have been brought on to the shooting-ground; $(d)$ carrying the gun of any sportsman who 
may desire to be temporarily relieved of it ; $(e)$ opening gates or otherwise assisting the guns to pass through or over obstacles ; $(f)$ indicating the proximity to good springs and burns; $(g)$ making inquiries from time to time as to any desire on the sportsmen's part for more cartridges; $(h)$ assisting the guns to make themselves as comfortable as possible in the butts; and (i) the hundred other little attentions that will suggest themselves to the courteous servant.

(4) The keeper must look to his health. This is not only a duty to himself, but also to his master ; must wear flannels next his skin, and have clothing and boots that will give him suitable protection from the vagaries of climate. He must see that he does not fall back upon the idiotic notion that, by putting whisky in, he can keep cold out, and make this habit an excuse for not changing his wet clothes. The latter must be serviceable, tidy, and quiet, and not of a pattern and colour that will scare game a mile away.

(5) The keeper, when off active shooting duty, should go about with a dog, and one which he gives a reputation for ferocity (even if it be as mild as a toy spaniel). He will thus be a terror to mischievous small boys and other minor depredators.

Of other miscellaneous duties the following will come under his observation :-

Larders. - It seems hardly necessary to say that there should be on every shooting lodge two larders, one for meat and the other for game. Larders should 
be large, clean, and airy. On no account should the flooring be too near the ground. An ideal larder would have the flooring four feet from the ground, and so placed as to ensure a free current of air passing beneath it. This ideal larder is built of stone or brick, tiled inside, and contains large windows, " paned " with perforated zinc, which open to the east, west, and north, the south side only being built solid and windowless for the sake of coolness. A small compartment for the use of the cook should be framed off from main larder, with a small window opening into it, through which the keeper gives game for the use of the house. The keeper has sole control of his larder, and the cook of hers, by a separate door; this arrangement saves much annoyance. Height is an important point in the consideration of space, and on no account should a ventilator on the roof be omitted.

An ideal larder, if only wood is employed, is to have both the meat and the game larders fairly close together, enclosed in a large wooden framework, which is covered with very finely perforated zinc or small meshed wire. This is a second protection and keeps out all flies, while allowing in on every side a free draught of air. The roof should be high, covered with shingles or slates. Entry is by door covered with wire. The floor is of concrete for cleanliness, and on that floor stands the two wooden larders one foot off the ground, thus a double protection against dust and insects ; and 
the roof of course shields the larders inside entirely from the rays of the sun. The inside larders have of course the usual perforated zinc windows. Door of the outside framework, as well as the larders inside, being all under lock and key.

There should be shutters on the outside of the perforated zinc windows, which should be closed in stormy weather, to prevent dust, etc., from being blown into the larder. The shelves inside should be of slate, and, of course, there should be plenty of hooks on which to hang the game, and in regular rotation as to the date of killing. Omission of the latter point is bound to lead to confusion in the mind of the cook. The larder, of course, must be kept thoroughly clean. The best site for a larder is a high mound, shaded, if possible, from the hot sun, and in a position to have the advantage of the prevailing wind and the benefit of any airs that blow. Spots under trees should be avoided, as the drip off the leaves is not favourable to that freedom from damp which is necessary for keeping game.

Disposal of Game.-When game is to be disposed of to dealers, arrangements should be made, before the shooting season, with respectable firms, and a contract price fixed, if possible, for the whole season, as many dealers are apt to return any price they like, varying it according to the character of the sportsman. If the latter happens to be an indifferent, easy-going person, the price is likely to be a small one; but if he is an 
exacting man, the sportsman will find he is able to gather better quotations. The keeper should ask for estimates from several dealers before accepting any particular offer.

In packing game for the dealer, the following rules should beobserved :-(I) Allgame should bethoroughly cool before being packed; (2) Fur and feather should not be packed in the same basket ; (3) Feathers should be carefully brushed and straightened, the head being placed along with a piece of heather under one of the wings ; (4) The heaviest birds should be placed at the bottom; (5) All badly shot birds should be kept for home use ; (6) Baskets should, if possible, be dispatched by train or steamer on the evening of the day on which the game is killed. Many keepers are apt to postpone the dispatch of game till the following day, and this often accounts for the bad returns sportsmen receive from the dealers. (7) A note of the quantity of game dispatched should be given to the sportsman, and should also be sent to the game-dealer.

Game Book.-The keeper's game-book should be kept correctly, regularly, and methodically. Details of the day's sport should be filled in every evening, and on no account should they be left over till the following day. The facts entered should include the number of guns, the details of the bag, the number of hours the guns were shooting, the state of the weather, the part of the ground shot over, and any particular and interesting circumstances relating to the day's sport that may 
have appealed to the keeper. It is as well also that notes be kept referring to the points of interest connected with the breeding season, also as to the stock of birds left on the ground after the shooting season is over. 
NOTES 
NOTES 


\section{CHAPTER XXIV}

TIPS

IT is neither easy nor pleasant to speak frankly on the matter of tips, and as it is a question that essentially concerns the master and his guests, it might seem an irrelevant subject for a keeper's book. And yet we feel that it will not do any particular harm for the keeper to listen to us " thinking aloud," and whilst we address a few observations to all whom it may concern. What was originally a recognition of good and special service has now, in every branch of life, come to be regarded as a matter of form, apart altogether from the fairness or justice of the question. In the cases of certain well-known restaurants where waiters are not paid, and are even compelled in many instances to pay for the privileges of their positions, a tip is in reality no longer a tip-it is a wage, and a most unfair and mean attempt on behalf of the proprietors to throw upon the pockets of the public the payment of their servants, while they retain sole control and the right of dismissal. It is generally admitted that the man who pays the piper calls the tune, and yet while the public pay the wages they have to take such service as they 
get, while the proprietor is the master. It is a difficult thing for a man to serve two masters. Of course, as at present, such tips are not obligatory in law, yet the justice of them appeals more or less to all concerned. The sooner the system is abolished, however, the better. But we do not wish to insult our friends by placing their servants in the same category as the unpaid waiter, and yet the conduct of many of these servants seems to be so regulated by the size of their tips that there is an occasional suspicion that the establishment in which they serve is run on the restaurant line. The practice of indiscriminate tipping has crept into every department of estate and household life, until the stable, the covert, the moor, the kitchen, and the pantry have all become free-flowing drains from thepocket of the guest. And it is not only the guest that suffers. The abhorrent practice of secret commissions, and the high-handed way in which many servants demand them, have compelled even trades-people to submit to this form of tyranny from pure sense of self-protection, with the result that the swindling is reflected back upon the master. In a large number of cases the tradesman is chosen, not from thequalityand comparativecheapness of his goods, but from the liberality of his tipping capacities. This line of procedure harms the master in two ways: he does not get the best value for his money, and he has the price of his goods raised so as to recoup the tradesman for the money he has doled out to the master's servants in bribes. Let us take an example relevant 
to the particular class of servant we are at present dealing with. Every competent keeper should, of course, be able to prepare his own pheasant food; if he is not, he does not possess one of the primary qualifications for his post. Yet it will be observed how eager many keepers are to run up large accounts with pheasant food manufacturers-either from laziness, or more often that they may receive the commission offered by certain firms to induce keepers to buy their commodities. We were told recently by a dealer in keepers' requisites that when he began business he tried to deal honestly by the employers, by not giving commissions to the servant, but so unusual did he find the practice, and so great was the dissatisfaction of the keeper, that he found that his chance of doing business was in danger, and he had, much against his will and against his sense of right, to pay the usual "blackmail" to the keeper, the amount of which was, of course, added to the price of the commodity supplied. Stable requisites from saddlers are increased 25 per cent. to cover the blackmail of coachmen and grooms ; anda corn merchant recently informed us that the demands for commission are so great that they have become a severe tax upon his profits, "for," said he, with feeling, "there is a limit of price at which even the most careless master will stop." Admitting those indisputable facts, all employers, on engaging their servants, while agreeing to pay them good, even liberal, wages, should make it clear that they will allow no secret commissions, and 
should indicate these facts to all manufacturers and merchants with whom they are dealing, and intimate that any suggested change in their business relations must be decided by them and not by their servants. In the majority of cases the dealer would be only too pleased to do business on these lines. With servants running riot in this way, it is no wonder so many people cannot live on their own places, but have to let them and go abroad, and so escape from the thraldom of unscrupulous servants.

An Act has now been passed prohibiting secret commissions. We are glad to observe that this has had good effect, and numbers of dealers in commodities under servants' control have only been too glad to escape from their blackmail. It only wants a little backbone and a little co-operation on the part of such firms to continue to resist any inroad, which may creep in through time, towards a renewal of this objectionable practice. A hint to the master would speedily put an end to it, and prevent the Act from becoming a dead letter.

From this form of "baksheesh" we pass to the question of tipping as it affects shooting guest and keeper. Now it is quite unnecessary for us to admit that there are a large number of shootings at which the traditions of moderate tipping are so maintained that no one except the meanest or the most cantankerous misanthrope objects to the common usage of recognising the services of the keeper by a small 
present of money. While we condemn blackmail, secret commissions, or baksheesh in toto, our object is not to advocate the abolition of tipping, but merely to press home the point that it should be kept in moderation, and with this all sensible keepers will agree. But if we count these shootings by the tens, we can enumerate the other sort by the twenties; and so excessive are the expectations of some keepers in these latter cases, that it is only the man of unlimited or very great means who can accept invitations to shoot. The man of moderate means, in fact, has to fall back upon moderate shootings, and the only deduction we can draw from this fact is that a guest has in reality to pay for his sport. We all know the story of the "Sovs. and Half-Sovs." "Put the sovereigns at the wood end, Bill, and the half-sovs. can walk with the beaters and stop back." But nowadays "sovs. and half-sovs." pale before the two guineas and the five-pound notes which are expected by some keepers, not for rendering any particular individual services, but simply because they are ipso facto keepers, and expect to be paid by the guests for the birds which they have had sent over the guns. So marked is the disagreeable attitude of some keepers to men of moderate means, that we are not surprised to hear of the increasing difficulty experienced by some sportsmen of getting guns. And it is a curious fact that, in our small experience at least, some of the very best shots are comparatively poor men, and not scions of an irresponsible plutocracy. 
Nothing is more galling to a good sportsman than to challenge him with an unsportsmanlike action, and yet the mere fact that he encourages the pernicious habit of reckless overtipping proves him to be careless of the interests of his brother guns. Such being the case, he is not a good sportsman.

We have constantly heard the argument put thus : "Surely the keeper of a good shoot should be tipped higher than that of a moderate one." Not of necessity. The keeper of the moderate shoot may show his birds better than that of the good shoot, if such a fact is to be taken into consideration. The same argument would apply in the case of a butler who gave us Château Lafite, and another who was only able to supply us with Médoc. "But," our friends reply, "in the case of the big covert shoot, look at the enormous labour involved." Are the guests, then, to be payers of wages? We reply, Certainly not. We give tips, not as part of a man's salary, but in recognition of special services rendered to us, or from desire to recognise the marked efficiency of the keeper : and in the latter case we give from our free will, and not in accordance with any stereotyped tyranny - a tyranny which found its most obnoxious and altogether unbearable expression in the case of a keeper who was seen to hold the proffered tip in his hand, to regard it with a look which combined curiosity with disdain, and then to hand it back with the remark that it was not up to his standard. The following stories are vouched for as true, though 
hardly credible. A sportsman was called away to town after the first day's cover shoot, and, having another shoot a few miles off, asked the keeper to send on his gun and cartridges by train to be waiting him there, tipping him a sovereign for the day's sport. Arriving at the shoot a few days later, he was surprised not to find his gun, etc., and telegraphed for them, and got back a reply from the keeper, "I will send on your gun when you give me my proper and usual tip, two sovereigns." Sending this letter to the keeper's master, he got the reply, "I can't interfere. Besides, it's the middle of my shooting season and I can't afford to quarrel or part with mykeeper-better pay." Another. - Smoke-room. Host informs his guests, "My keeper's tip is a fiver." They all decided to tip low. None were asked back. The only conclusion one can draw from these stories is that the master was a cad and looked to his guests to pay his servants.

The nouveau riche we fear is the sinner who has encouraged heavy tipping, which is a species of selfishness, prompted by two reasons : first, in order that he might get the best of everything; and, secondly, to show that he has plenty of money. The first reason is unsportsmanlike, and inconsiderate of his fellow-guests, while the second shows him to be vulgar and purseproud.

In studying the matter of tips, it were as well to get to the foundation of the habit. Etymologically the word means something small, and originally it meant something secret or sub rosâ ; now it has grown to mean 
something big and something very much advertised and above the table. We began to tip porters when we found that they had to deal with very heavy luggage, or when they ran for our cabs, or were in any way particularly smart; now we tip them as a matter of course. A tip was, and ought to be now, a recognition of special service. We tip the valet because he looks after our clothes, and we tip the gamekeeper, not for having a fine stock of hand-reared pheasants, but because he cleans our guns, or holds them as we get over fences, or helps us at the luncheon hour. If every man remembered this fact, tipping would come back again to that level of moderation which seems not only desirable but necessary.

As we have said, it is no pleasant task to write on this subject. A charge of meanness is abhorrent to every Briton, and more so to every sportsmen of the race, and in the long-run it is better to give too much than too little. But let not our argument be interpreted as a subtle apology for meanness. There are hundreds of first-class keepers who deserve every farthing they get, and there are no tips that are given with greater delight than the tips to the keepers who have shown birds flying high and strong, who have worked their beaters or their dogs to the satisfaction of everybody, and to the advantage of the bag, who combine, in all they do, skill with courtesy and energy with patience, who present our guns every morning as clean as the day they left the gunmaker. Especially do we 
rejoice to recognise the keeper who gives us a good day over dogs, who is keen that we should go on, who works his ground for all that it is worth, and who is interested in the way we shoot, and anxious that he, his underlings, and his dogs should do us more than justice. Such a keeper does not look upon us as the mere carrier of a tip. He performs his duties out of respect to his master's wishes, out of love of the sport itself, and principally from that noble self-respect which is the foundation of all capable labour. Where such a keeper is in charge, there will not be heard the common complaint that a man cannot go for a weekend's shooting without five pounds in his pocket, two of which are to go into the pocket of the keeper, one to be given to a loader, and the other two to be distributed amongst the rest of the men-servants in the establishment. This is a great hindrance to hospitality, and deprives hosts of the pleasure of entertaining their friends. Many of the most amusing and charming of guests are often the poorest, and we know of cases where the host has had actually to supply the tips for his guests, in order to facilitate a more pleasant departure. This is a wrong state of matters, and it is a pity it should exist. There are one or two isolated cases where no tips are allowed on any pretext in the houses of wealthy men, and an arrangement is come to between the master and his servants for a bonus being paid at the end of the season according to scale, instead of the usual tips. This plan should become 
more general. It would mean very little extra expenditure to the host, and it would save him many an unpleasant upsetting in his household, by servants choosing the most inconvenient time to give notice. He would thus get better service, and retain a more complete control ; in any case, they would wish to be on their best behaviour and remain on till the annual distribution. Ladies should be exempt from tipping men-servants in any circumstances, and head-keepers only should be tipped; under-keepers wait their promotion before they are recognised. In other houses it is the custom to place a money-box marked "Keeper's Fund" in the gun-room. This is advocated by Lord Walsingham, and is an excellent plan.

It is not possible to suggest any absolute scale of tips that might be regarded as a reasonable average. Of course if a man be very poor his tip must be very small, and in certain cases it should not be given at all. For instance, where a keeper has by bungling and incapacity shown poor sport, not only has he put the guests to considerable trouble in coming with the intention of shooting, and spending a pleasant day, while it has only been one of annoyance, but he has heaped on his master a considerable indignity, and made him ashamed of his shoot, as well as his servants. Many masters on such an occasion intimate to their guests there will be no tips. For a week's stay at a house where there is, say, three days' shooting over dogs, an 
average and fair tip from each guest would be a pound from a man who was fairly well off, and ten shillings from the man of moderate means, a few shillings being given to the man or boy who carries the cartridge bag. For a single day's grouse shooting, five to ten shillings is a good and moderate fee; ten shillings is a very generous one. For a day's covert shooting the same applies, although we have generally found that the common tip, especially in England, at the first shoots, is a pound a day. In small or single day shoots it is a usual and sensible practice for the guests, where they intend to give a tip, to consult together and all give the same; and let the tip be moderate and to suit the pocket of all, so that no one will feel that he has given more than he can afford or wishes to. It may be laid down as a safe and general law that no tip, unless in those very exceptional cases where a man has made a prolonged visit to a shooting, should exceed a sovereign, and that no man of moderate means should be ashamed of giving half that amount, or nothing at all if he is so minded. It must be remembered that it is purely a mark of goodwill and a present, and in no way should be expected, and that a sportsman loses nothing by the supposed loss of esteem of a greedy keeper or servants of any kind; nor in such a case should he hesitate should he wish to accept the hospitality of such a shoot again. Finally, the necessity for heavy tipping does not now exist, as every master who is a real sportsman, and anxious to do each guest justice, 
places the guns himself, instead of leaving his duty to the keeper.

Secret commissions come within the category of tips, and although they are in reality a species of dishonesty, which tips are not, they have almost grown to be recognised as respectable. Since the passing of the Act to prohibit it, however, the practice has very much declined, and rightly too. There is a society now in existence to carry out the provisions of this useful Act, and it is to be hoped that all who have it within their power will endeavour to prevent it from becoming a dead letter. 
NOTES 
NOTES 


\section{INDEX.}

Adders, 117.

Angler-fish, 390.

Angling law, 363 .

Badger, 105.

Baksheesh, $45 \mathrm{I}$.

Bass fishing, 388, 405 .

Black game, I87; driving, I89; poaching, I9r.

Bracken, I7I.

Brailsford rabbit trap, 265.

Burgess rabbit trap, 263.

Butts, 180.

Buzzard, 120.

Capercailzie, 317.

Cat, wild, I 10.

Cats, poaching, 59.

Chorea in dogs, 91 .

Close times, tables of, 62 ; for salmon, 365,380 .

Coalfish, 406.

Coarse fish, 379.

Cocks, destruction of old, 162.

Cod fishing, 406.

Conger eel fishing, 389, 405 .

Convulsions in dogs, 92.

Coveys, exchange of, $16 \mathrm{I}$.

Crows, I3o.

Cruickshank rabbit trap, 263.

Dead matter, removal of, 168.

Decoy duck shooting, 308.

Deer, deterioration of heads, 239.

Deerstalker, dress of, 229.

Deerstalking, 227.

Distemper in dogs, 89.
Dog, the, 67; exhibition of, 70 ; selection, 72 ; training, 75 ; choice of breed, 84 ; common ailments, 86 ; kennels, 94.

Dog-fish, 390.

Dogs, poaching, 59.

Duck, wild, 29I ; stalking, 298.

Eagle, golden, I 18.

Eczema in dogs, 93.

Eggs, exchange of, 160.

Excise licences, tables of, 63,64 .

Farmers, relations with, 2 I ; rights, law of, 46.

Farm hands, employment of, in sport, 26.

Feeding birds in hard weather, 156.

Feeding-ground, improvement of, I68.

Ferrets, 258 ; disease of, 260.

Fish hatchery, 417 ; rearing ponds, 433 ; carriage of fry, 434 ; cost of, 436 .

Fish, hatching, 415; method of handling, 425 ; ova treatment, 427.

Fishing gillie, 343 .

Fishmongers Company of London, 372.

Fits in dogs, 92.

Flighting of wildfowl, 303 ; wildgoose, 3II.

Fox, 107.

Fresh water (Scotland) Act, 377.

Game-book, 447. 
Gamedealers' licences, 49.

Game, diseases of, 327 ; disposal of, 446 .

Game laws, 42 ; leading books on, $6 \mathrm{I}$.

Goose, wild, 310.

Grey mullet fishing, 388, 405 .

Grouse, artificial rearing of, 172 ; picking up and packing, I86; shooting, over dogs, 173 ; driving, 176 ; disease, 327 .

Gun cleaning, 339.

Gun licences, 48.

Hares, 320.

Heather burning, I50; law of, 47.

Hedgehog, II 5.

Hill ponies, 187 .

Hints to loaders, $33^{8}$.

Interbreeding, evil effects of, 158.

Keeper, apprentice, 143 ; his duties, I 45.

Keepers, capable and incapable, 2 ; relationship between masters and, 9 ; ideal, I 3 ; authorities they should consult, I6; relations with farmers, etc., 2 I ; friendship with neighbours, 27 ; points in law they should know, 39 ; miscellaneous duties of, 44I.

Kennels, 94.

Kestrel, I28.

Larders, 444 .

Law, points a keeper should know, 39 ; things forbidden by, 57.

Licences to kill game, 50; in Ireland, 5 I.

Loaders, 335 ; hints to, 338 .

Loch trout fishing, 356 ; improvement of, 358 .

Lochs, feeding supplied to, 436.

Magpie, I3I.

Mange in dogs, 92.

Master and servant, law of, 39.

Merlin, 127.

Miscellaneous sport, 315 .
Moor, the, I49; heather burning on, I50; water supply, I53; vermin, 156; poachers, 156; feeding birds in hard weather, 156 ; introduction of new blood, 158 ; exchange of eggs, 160 ; of coveys, 161; destruction of old cocks, 162 ; judicious planting, I65; control of number of sheep, 166 ; improvement of feedingground, 168 ; removal of dead matter, I68; wire fences, I70; telegraph wires, 170; bracken, I7I ; butts, I80.

Otter, 106.

Owls, 132.

Partridge, the, I95; cover for, 202 ; nests, eggs, and artificial rearing, 204; feeding young, 212 ; improvement of stock, 215 ; walking up, 218 ; driving, 222 ; poaching, 224; disease of, 331.

Peregrine falcon, I2I.

Pets, consideration of, 27.

Pheasant, the, 269; rearing, 27I ; food, 278 ; poaching, 280 ; shooting, 281 ; placing of guns, 286 ; disease of, 329.

Pigeon shooting, 316.

Plover, 315.

Poachers, 3I ; arrest of night, 53.

Poaching, 24, 52, 54, 55, I 56, I9I, 224, 266, 280, 32I, 366, 376 ; Prevention Act, 56.

Poison, 57.

Pole-trap, 137.

Pollack fishing, 406.

Porpoises, $4 \mathrm{I}$ I.

Price's rabbit trap, 265.

Ptarmigan, I9I.

Punting, 309.

Rabbit, the, 245 ; warren, $25 \mathrm{I}$; shooting of, 256 ; ferrets and ferreting, 258; keeping down, $26 \mathrm{I}$; traps, 263 ; poaching, 266 ; disease, 332 . 
Rat, the, I 6.

Raven, 129.

Rearing ponds for fish, 433.

Rheumatism in dogs, 93.

Rickets in dogs, 88 .

Rivers, pollution of, 435 .

Roe shooting, 320.

Salmon, fishing from bank, 343 ; from boat, 35I ; harling, 355 ; trolling, 356 ; legal definition of, 364 ; private rights, 365 ; close times, 365, 380 ; netting, 365 ; poaching, 366 ; fisheries (Scotland) Acts, 367 ; keepers and water bailiffs, 370; hatching, 424 ; carriage of fry, 434 .

Salt water fishing, 383 ; tackle for, $39 \mathrm{I}$; bait, 396 ; sport at various resorts, 403 .

Seals, 4 I I.

Sewin, 288.

Shark fishing, $390,406$.

Sheep, control of number of, 166.

Shipley, Dr., on grouse disease, 328 .

Shooting on Sunday, etc., 58.

Shooting rights, law of, 44 .

Snipe, 32 r.

Sparrow hawk, 125.

Sport, a branch of science, I 5 ; authorities on, I 5 ; miscellaneous, 315.
Spring guns, 60.

Stoat, i ro.

Telegraph wires, 170.

Tips, $45 \mathrm{I}$.

Traps, vermin, I37 ; rabbit, 263.

Trout, legal definition of, 372 private rivers, 373 ; lochs, 374 ; public rivers and lochs, 375 ; poaching, 376 ; keepers and water bailiffs, 378 ; hatching, 424; carriage of fry, 434 ; feeding supplied to lochs, 436 ; (Scotland) Acts, 376, 377.

Vermin, 103, 156; traps for, I 37.

Water bailiffs, 370, 378.

Water supply on moors, 153 .

Weasel, II2.

Whales, 4II.

Whiting fishing, 406.

Wild Birds Protection Acts, 58.

Wildfowl : feeding, 307: shore shooting, 308; bog shooting, 308 ; decoy duck-shooting, 308 ; shooting afloat, 309; punting, 309.

Wildfowling in Scotland, 303.

Wire fences, 170.

Woodcock, 318. 
Printed by

Morkison \& GibB Limited

Edinburgh 


\section{SCOTCH WHISKY.}

We confine our business entirely to Scotch Whisky, and to compete with the Stores our prices are fixed at lowest possible cost for cash business, and will be found to be $2 /=$ to $6 /=$ per gallon lower than our competitors; quality is our first consideration. All our Whiskies come direct out of Distillery Bonds.

\section{BLENDS.}

Per Gall. Per Doz.

THE MACKINTOSH. (A Connoisseur's Io Years Old) 25/3 52/6 STIRLING LIQUEUR. (I5 Years Old) . . . 29/3 60/6 GINGER WHISKY. (Old Liqueur) . . . . . .. $52 /$ -

An excellent after-dinner digestive, and invaluable for warding off chills on the moors and hunting field.

CLEAR WHISKY. (Red Cross Brand.) Special

Reserve. . . . . 26/ 60/

For Gouty Patients a Medicinal Speciality.

We prefer to sell our own Blends, but where others are wanted we have made a selection of the best-known Blend, also a single Whisky direct from Distillery-Pure Malt Pot Still, and after careful sampling make a speciality of the following two :-

WHITE HORSE CELLAR. (Io Years Old) . . ... 54/-

The Famous Coaching Blend of $x_{742}$.

SPECIALLY SELECTED "LAGAVULIN." (Io Years

Old) . . . . . . . . . . . . . 54/

also Glengrant, Clynelish, Talisker, Oban, Craigellachie, from 8 to io Years Old, at prices from 25s. to 3os. per Gallon according to Age.

Carriage paid. Casks and Jars charged extra.

Terms: I per cent. for cash in 14 days, or 3 months net.

Being only Wholesale Retailers, we cannot send single bottles as samples, but will send an assorted case of one dozen bottles-which is the smallest quantity we can sell by law-of two bottles of each of above Blends, on receipt of cheque for 53 s.

\section{MACKINTOSH \& MACKINTOSH,}

Scotch Whisky Blenders, STIRLING, N.B. 
8.

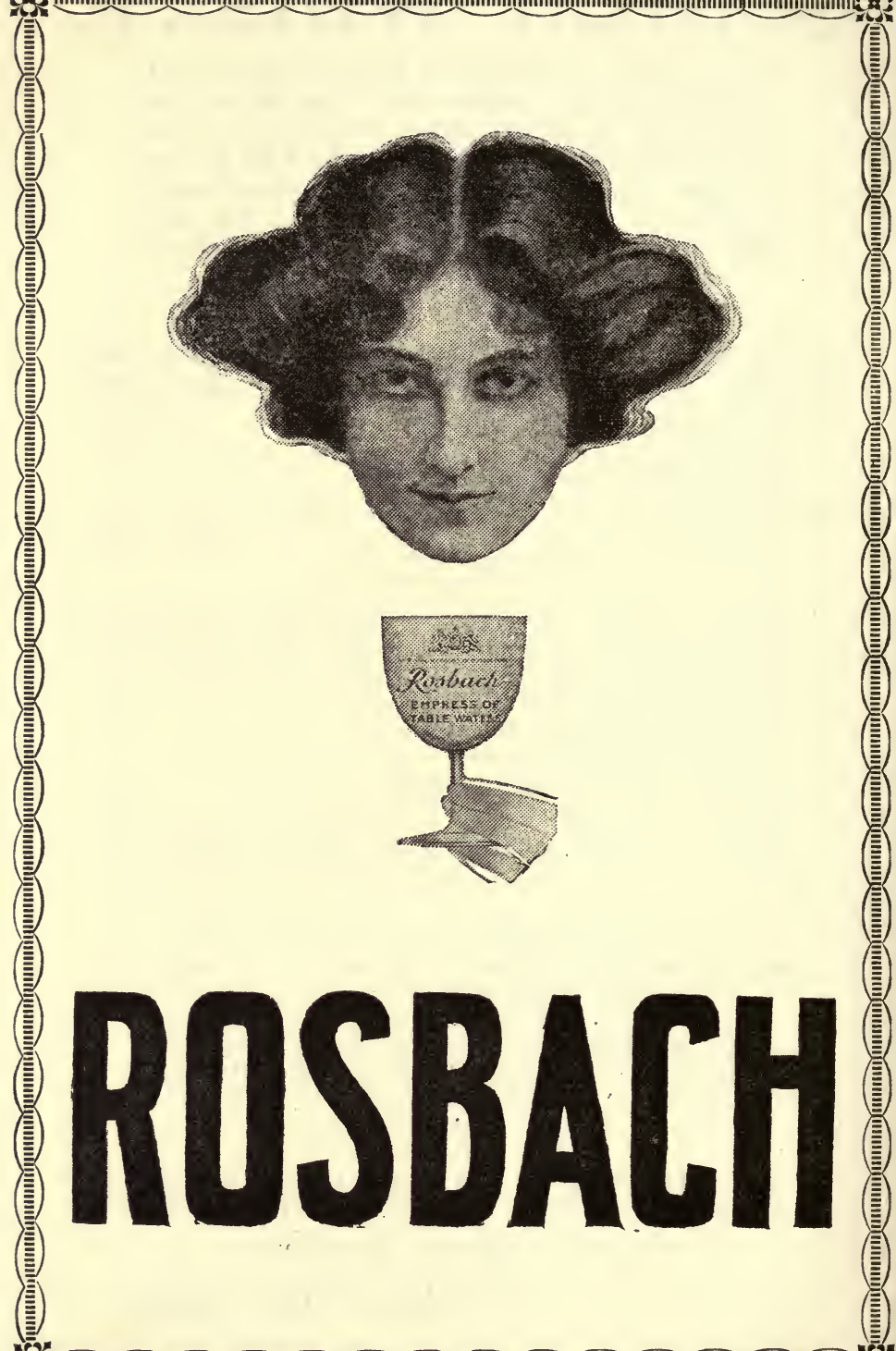

\% 


\section{Everywhere the Sportsman's Favourite Beverage}

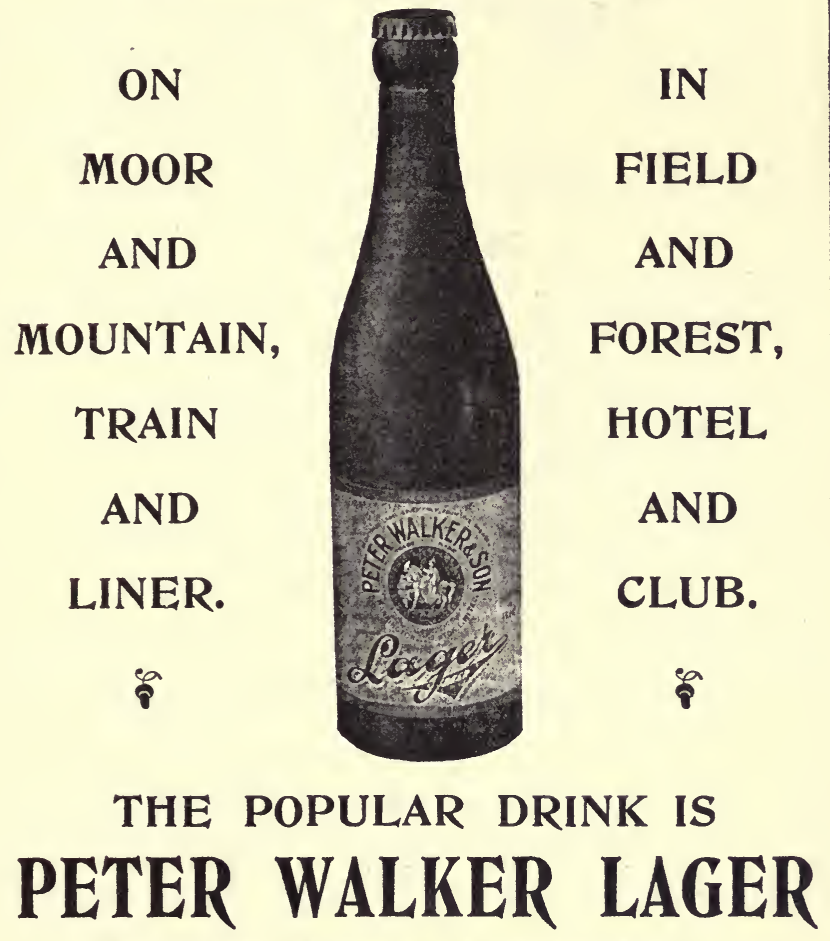

The Purest of Beers. Always Sparkling. Nourishing, Appetising. Fatigue and Thirst CAN'T RESIST “LITTLE PETER."

Brewed at Burton from only the Best Malt and Hops.

$2 / 3$ per dozen. Order from your Grocer

IF ANY DIFFICULTY IS EXPERIENCED WRITE TO PETER WALKER \& SON (WARRINGTON \& BURTON) LTD., IO5 DUKE STREET, LIVERPOOL. 


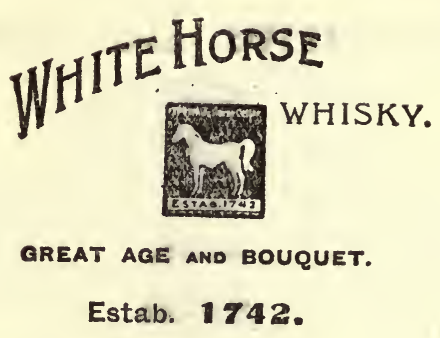

This Whisky is distinguished by its great age and bouquet. It is dry, pure, and not loaded with sweetening like many cheap whiskies.

It is amongst whiskies what Pommery is in Champagne or Château Lafite in Claret.

Mixes equally well in Plain or Aerated Waters.

Ask specially for WHITE HORSE, and not merely, whisky, and see you get it.

\section{MACKIE \& CO. DISTILLERS L ID}

LAGAVULIN DISTILLERY, ISLAND OF ISLAY,

GLASGOW AND LONDON, 
GLASGOM.

ST. ENOCH STATION HOTEL. Best centre for Business Gentlemen, Families, and Tourists for Western Highlands, Trossachs, and the Firth of Clyde.

Newly arranged Suites of Sitting-, Bed-, and Bathrooms en suite.

AXR.

STATION HOTEL; for Burns' Cottage, Monument, and the lovely Ayrshire district.

DUM FRIES.

STATION HOTEL; for Caerlaverock Castle, Sweetheart Abbey, and the charming Firth of Solway.

\section{TURNEIRRY.}

STATION HOTEL. Two fine is.Hole Golf Courses. Sea Water Baths. Tennis. Croquet. Bowls. Garage. Stables.

Ideal Centre for Autumn, Winter, or Spring Holiday.

For further particulars, address "RESIDENT MANAGER"

at the respective Hotel, or

J. H. THOMAS, Manager,

G. \& S. W. Railway Gompany's Hotels, GLASGOW. Telegrams : "Souwestern."

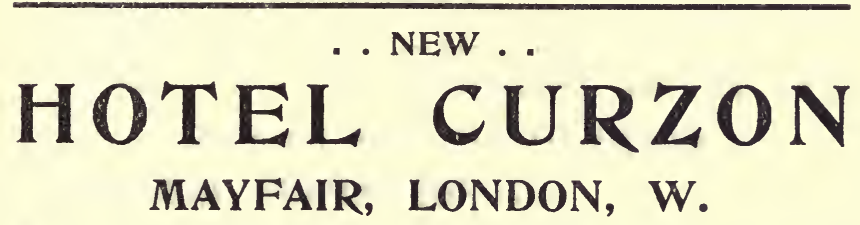

The most Fashionable and Central position in London.

Absolute quietness, no thoroughfare or traffic passes the Hotel.

- Famous for its cooking, wines, and artistic decorations. -

The Restaurant with Foyer is one of the prettiest Dining

Rooms in London, as declared by visitors and Press. . .

A unique feature is the Heating and Ventilation

- of the Hotel and Restaurant.

The air is washed and purified before entering the Rooms.

Terms à la carte or en pension.

Telegrams: "Hotel Curzon, London." Telephone No. 8821 Gerrard.

6. HARWATH, Proprietor. 


\section{The "GRAND" charing cross, GLASGOW.}

In close proximity to

S. ANDREW'S HALLS and New King's

- Theatre. -

THE PREMIER HOTEL IN THE

WEST OF

SCOTLAND.

Telegraph Address

" COMTORT," Glasgow.

Telephones:

Post Offce, $\mathbf{3 4 7}$.

National, 961, 962.

and 963 Charing

Cross.

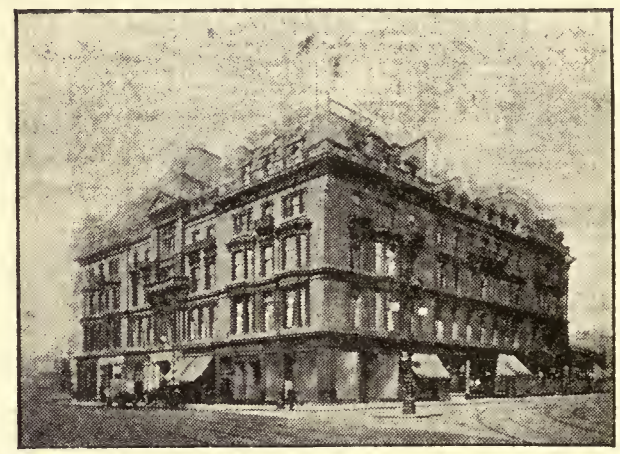

Exquisitely Decorated and Superbly Furnished. Situation unequalled, being within easy access of the various Railway Stations, the leading Theatres and Music Halls, and all the places of historic and industrial interest with which the City abounds. First-Class Cuisine. Boarding Terms. Marriages, Dances, and Banquets.

\section{Proprietors-THE GRAND HOTEL (Glasgow), Limited,}

\section{A. \& J. MAIN \& Co. LTD.}

\section{CLYDESDALE IRON WORKS, ON POSSILPARK, GLASGOW.}

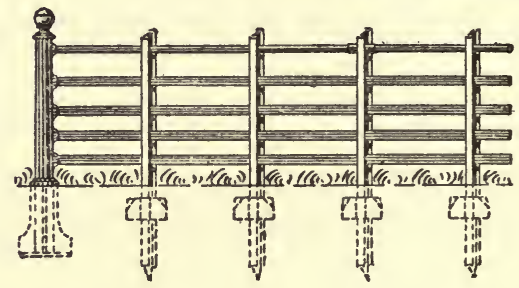

STEEL AND IRON BUILDINGS of every description.

WROUGHT=IRON RAILING, GATES, dc. \&c.

IRON AND WIRE FENCING. CATALOGUES and PRICES ON application. 
You are probably interested in the rearing and preservation of

\section{Pheasants, . . Partridges, \& Wild Duck. .}

We shall be pleased to send you our pamphlets, which contain much useful and practical information on the rearing of these birds. Also our Price List of . . .

\section{Game Foods and} Appliances

Hin With testimonials, illustrations, and full particulars. .

Our foods have upwards of 25 years' continuous success to recommend them, and are used by Game Preservers in all parts of the kingdom. . .

\section{Gilbertson \& Page \\ Ltd.}

Game Food Manufaoturers by Appointment to . . . HIS MAJESTY THE KING.

\section{Hertford, Herts.}




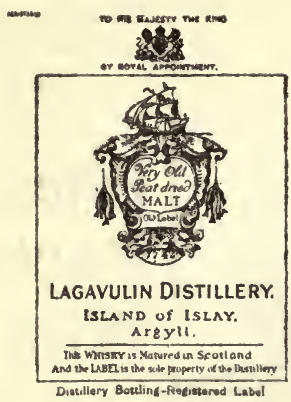

EXTRA SELECTED

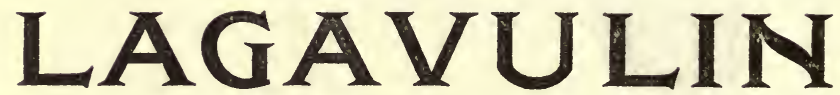

GUARANTEED PURE MALT. POT STILL-IS YEARS OLD.

$T$ is pure genuine natural whisky, 15 years old, and the quality will 1 gain for it the custom of all connoisseurs of whisky as the best value in the market, its distinguishing feature being softness, bouquet, and great age.

Besides a few show-cards, the chief method of advertising adopted by the proprietors is small samples of the Lagavulin in miniature bottles.

The Lagavulin Distillery is the oldest in Islay, the business having been actually commenced in the year I742. At that period it comprised ten separate little smuggling bothies clustered together at the foot of the hills, on the shore of Lagavulin Bay, which place was frequently the scene of daring encounters between the smugglers and the Government officers. The old secrets are still preserved.

The mashman at Lagavulin Distillery has been in the employ for over 55 years, and his father was mashman for 50 years before him, and the grandson has already been 18 years. This is a record hard to beat, and the average service of all the employees is over 25 yearsmany of them over 30 and 40 years in the service.

The peat used for drying the malt is always kept for three years in a covered shed.

Along with the malt we mash a certain proportion of young shoots of heather bloom-to this is accountable the beautiful bouquet so many have failed to imitate.

A year's supply of heather in full bloom is cut each September, tied into small bundles, and stored carefully.

To be had from all First-class Wine Merchants, etc. 


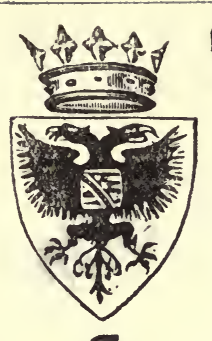

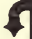

\section{SAVOY HOTEL,} LONDON, W.C.

\section{THE HOTEL DE LUXE} OF THE WORLD.

The comforts and luxury of the Savoy Hotel, its cuisine and service, combined with the most moderate charges, place it absolutely in the front rank of all Hotels in Europe.

gustaVe SEGGELKe, Gen. Manager.

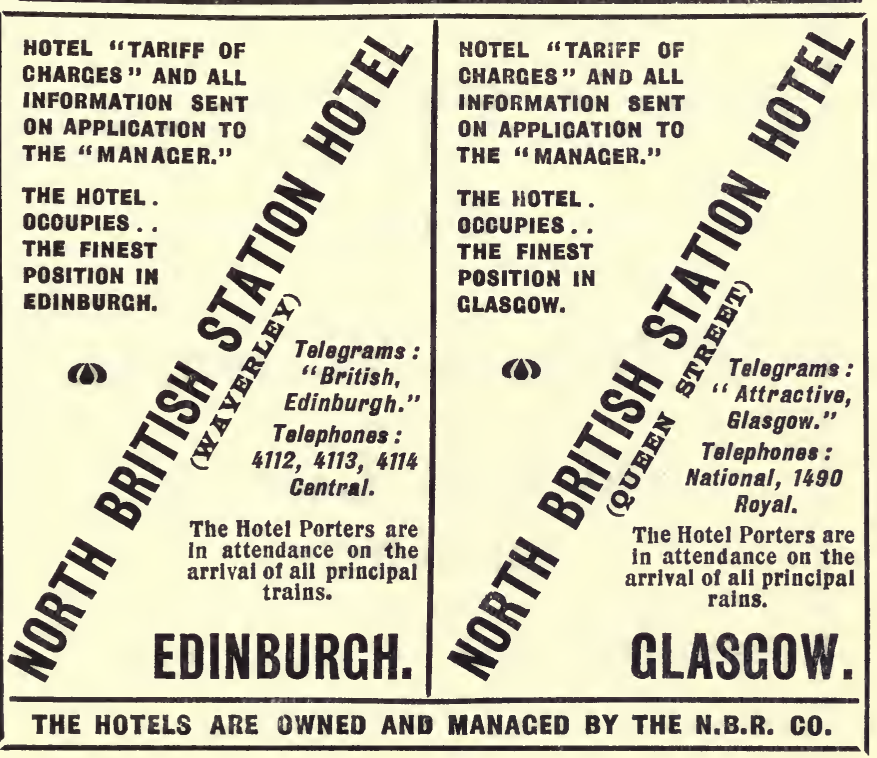




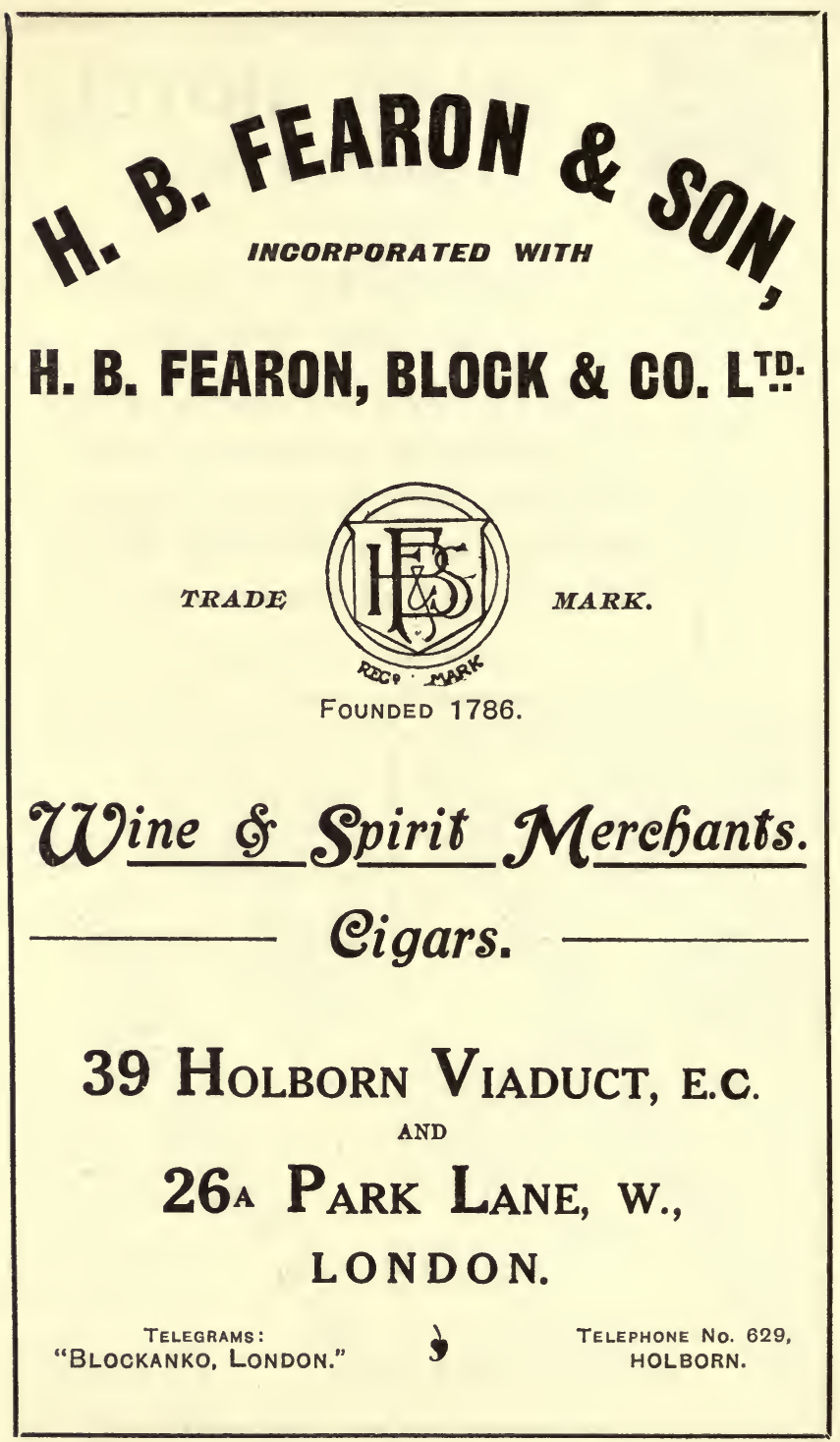




\section{GREAT NORTH OF SCOTLAND RAILWAY.}

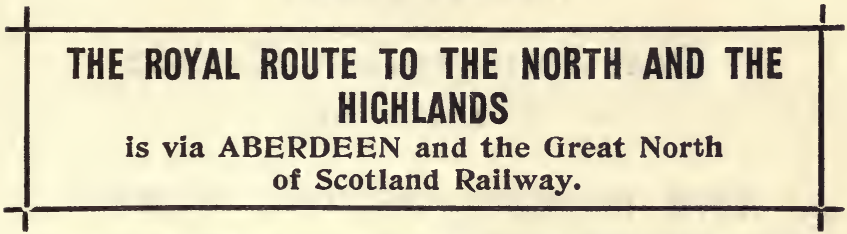

\section{ROYAL DEESIDE, "The King's Highland Home."}

Tourists and Visitors to Aberdeen (the Granite City) can visit Ballater, Balmoral, and Braemar in one day comfortably by the quick and convenient train service to Ballater, and motors and char-à-bancs in connection therewith. Special facilities for visiting these resorts, as well as Banchory and Aboyne, on Wednesday and Saturday afternoons during summer.

\section{CRUDEN BAY, "The Brighton of the North."}

Delightful Seaside and Golfing Resort, 30 miles from Aberdeen. Fine, hard, sandy beach over two miles long. Sea-bathing, Boating, Fishing. Splendid rock scenery in district. Coupon Tickets to Cruden Bay issued at Aberdeen by all trains daily at a charge of $6 \mathrm{~s}$., including third-class return fare, luncheon in the Company's handsome Hotel, electric car from Station to Hotel, and use of the renowned Golf Course.

\section{SPEYSIDE, "The Land of the Grants."}

The Speyside Line is the scenic route of the Company's Railway system. Excursion Trains, provided with luncheon cars, run from Aberdeen every Wednesday and Saturday afternoon during summer; unrivalled for speed, comfort, and popularity ; 200 miles for $2 \mathrm{~s} .6 \mathrm{~d}$.

\section{THE "THREE RIVERS TOURS," "Our Beautiful Land."}

A Holiday in Scotland would be incomplete without a visit to the magnificent country through which flow the three famous Scottish rivers, the Dee, Don, and Spey, and this can be accomplished by means of the "Three Rivers Tours," embracing a most interesting combination of journeys by rail, motor, and coach. The Tours operate daily from July to September, and may be commenced at Aberdeen or any point on the route.

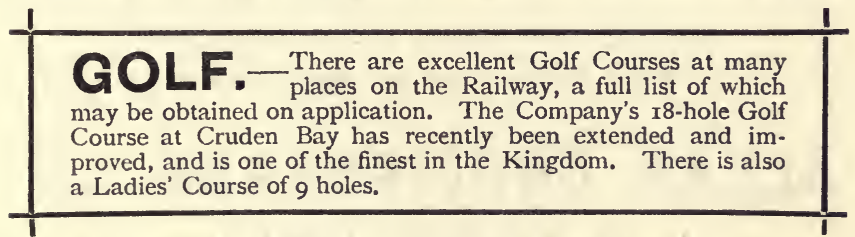




\section{"THE $O$ O}

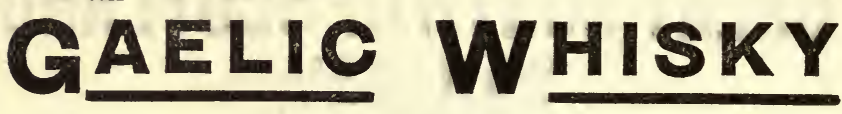

IN THE

\section{Old Smuggler Bottle}

— 10 YEARS OLD -

is

THE PUREST OF THE PURE."

(Extract from Court Circular of ist December 1900.)

Proprietors $\infty \propto$

\section{STIRLING BONDING CO.,}

a The Distillery, Craigellachie, N.B.

Obtainable only from Wine Merchants and Licensed Grocers

\section{CRUICKSHANK'S PATENT TRAPS.}

Over two hundred written testimonials from Head Gamekeepers.

The lightest, quickest, surest, handiest, and most durable traps in the market. future."

Capable men will find them to be "the trap of the

4 inch best single spring Toothjaw, 24s. per doz, cash, retall.

3

"21s. "

"1

Sold by Gunmakers and Ironmongers.

Full Price List on application.

ALLAN CRUICKSHANK LTD.,

67 M'ALPINE STREET, GLASGOW. 


\section{M'Corquodale \& Co.}

LIMITED.

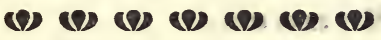

COMPANY

PROSPECTUSES

AND

ILLUSTRATED

CATALOGUES.

GAME ADDRESS LABELS.
Letterpress and

Lithographic

Drinters,

Stationers, and

Account took

IIsamufacturers.

(D) (D) (D) (2) (2) (2)

LONDON - $\quad-\quad-\left\{\begin{array}{l}40 \text { AND } 41 \text { COLEMAN ST., E.C. } \\ \text { CARDINGTON STREET, N.W. } \\ \text { ST. THOMAS STREET, S.E. }\end{array}\right.$

WOLVERTON (BUCKS). :: NEWTON (LANCASHIRE).

GLASGOW - CAXTON BUILDINGS, MAXWELL STREET. 


\section{SHOOTING, FISHING, ESTATE, COAST, \& \&OUNTRY HOUSE AGENTS.}

\section{TOM \& JAS. SPEEDY,}

$17 \mathrm{st}$. Andrew Square, EDINBURGH.

Lists Free on application.

Messrs. SPEEDY are practical, and have inspected and reported on SHOOTINGS, FORESTS, FISHINGS, and MANSIONS all over the Country for very many years.

\footnotetext{
"On the taking of a moor Mr. Speedy is quite a mine of information."-Liverpool Mercury.

"Mr. Speedy is practical, and has wide experience of the whole range of Scottish sport." - Times.

"Mr. Speedy has large personal experience."-Glasgow Herald.

"Mr. Speedy is practical."-Land and Water.

"Mr. Speedy is practical and trust worthy."-Truth.

"On fishing, shooting, and deer-stalking, Mr. Speedy is practical." $\longrightarrow$ Saturday Revier.

"Mr.Speedyhas had long experience on moor, river, and loch."-Southern Reporter.

"Mr. Speedy is an adequate authority."-Harper's Monthly Magazine.

"Mr. Speedy is a keen and experienced sportsman."-Dundee Advertiser.

"Mr. Speedy's hints are sensible and useful."-Daily Free Press.

"Mr. Speedy's hints on the taking of a moor may be the means of saving interested parties much worry and disappointment." - Aberdeen Journal.

"Few will hesitate to acknowledge that Mr. Speedy has personal knowledge, experience, and observation."-Midland Counties Herald.
}

\section{A G E N T S}

\section{for all Sporting Requisites.}

Pheasant and Game Foods, Dog Biscuits, etc.

Pheasant Eggs from all the leading Pheasantries.

\section{CRUICKSHANK'S PATENT RABBIT AND VERMIN TRAPS.}

These traps, ordinary toothjaw or humane, are the best in the market. Last longer than others. Parts can be renewed. Four dozen traps and chains are $36 \mathrm{lb}$. lighter than the best of the old flat springs. 


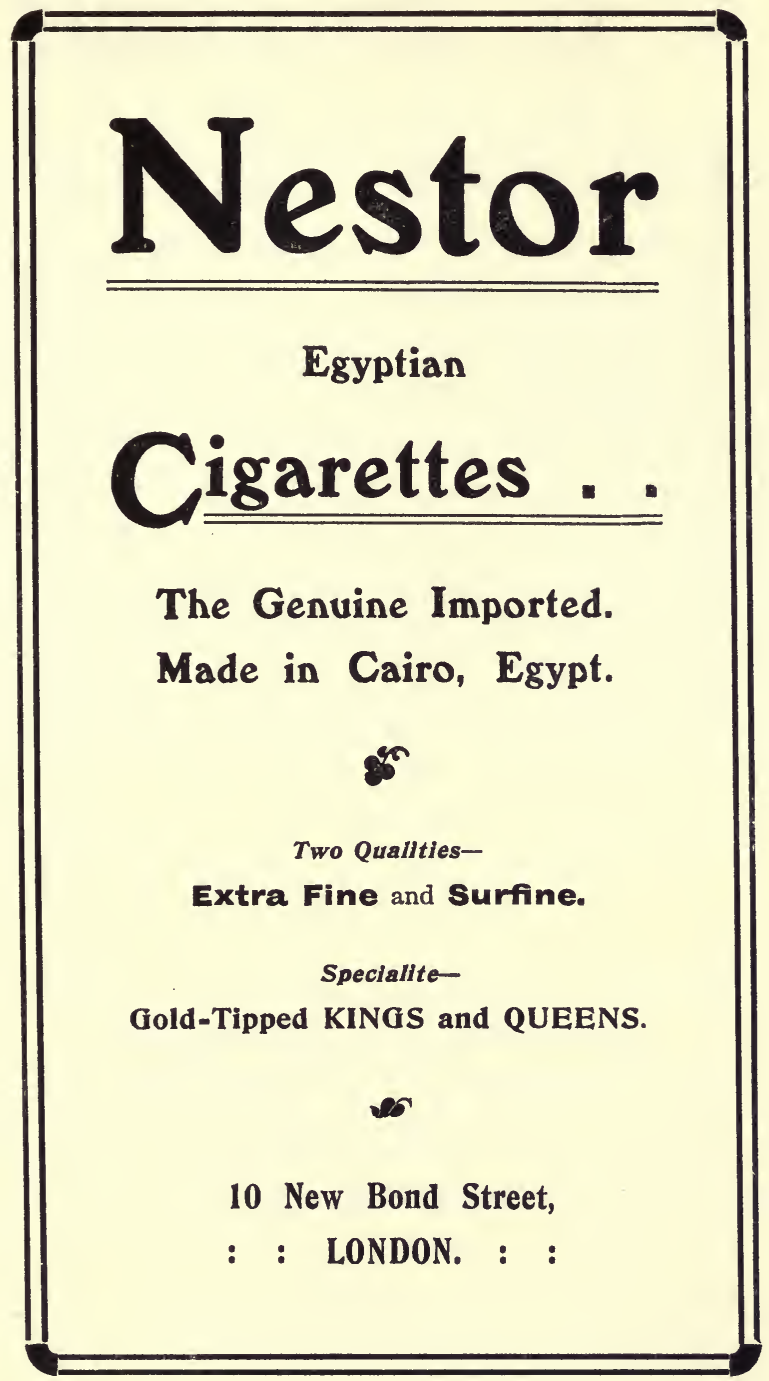




\section{P. D. MALLOCH,}

Fishing Tackle Manufacturer, SCOTT STREET, PERTH, N.B.,

MANUFACTURER OF EVERY DESCRIPTION OF SUPERIOR FISHING TACKLE SUITABLE FOR ALL PARTS OF THE WORLD.

MALLOCH'S NEW PATENT CASTING REEL, Improved Pattern in Gun Metal or Aluminium; the greatest boon to Anglers yet invented for Salmon, Mahseer, and Trout, and all kinds of Coarse Fishing. Unsurpassed for Long-distance Casting ; simple, and easy to learn.

\section{Rods and Lines specially suitable for these Reels.}

MALLOCH'S PATENT FLY CASE for Salmon, Grilse, Sea Trout, and Eye Flies of all sizes. Handy and compact. Each Fly secured by neat and effective arrangement.

MALLOCH'S NEW KINGFISHER LINE is absolutely the best line ever offered to anglers. It is thoroughly waterproof, and has a perfectly smooth surface which never cracks or knuckles.

Sample Cards free on application.

MALLOCH'S NEW PATENT INVISIBLE SPINNER.

MALLOCH'S NBW PATENT BOAT ANGLER.

MALLOCH'S GOLD MEDAL SALMON AND TROUT REELS IN GUN METAL AND ALUMINIOM.

Illustrated List Free. Telegraphic Address : "MALIOCH, PERTH."

Prize Medals awarded National Fisheries' Exhibition, Norwich, x88x ; International Fisheries' Exhibition, Edinburgh, x882. The Highest Awards at the Great International Fisheries' Exhibltion, London, r883; Gold Medal for General Collection of Rods and Tackle; Gold Medal for Flies; Gold Medal for Salmon Reels; Gold Medal for Trout Reels; Medal for Trout Rods; Medal for Salmon Rods; Special Money Prizes for Salmon and Trout Reels; Special Money Prize for Salmon Flies; Six Diplomas of Honour ; Silver Medal, Bolton, 1889, for Casts of Fish. 


\section{WOODHALL SPA, LINCOLNSHIRE.} VICTORIA HOTEL.

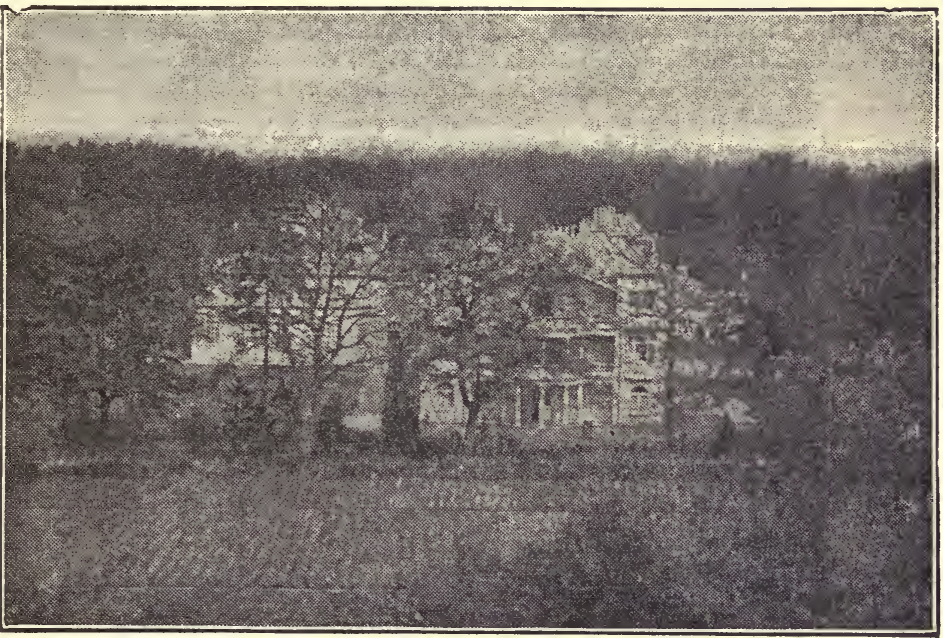

The SPA BATHS \& PUMP ROOM in Hotel Grounds. ... I50 Rooms. Suites. Grounds of Io acres... Electric Light Throughout.

Golf. Tennis. Eroquet. \& Garage. Stabling.

BATH DEPARTMENT.

Famous BROMO-IODINE SPA BATHS newly enlarged. SPECIALTIES :-

Mineral, Nauheim, Pine, Vapour, Needle, Dowsing Heat and Light Baths, Aix and Vichy Douche Massage, High-Frequency and complete Electrical Installation, Throat Sprays.

Illustrated Tariff and particulars of Hotel and Baths on application.

Telephone : No. 25 . Telegrams : "Victoria, Woodhall Spa." Apply, THE MANAGER. 


\section{SPORTING AND OUTDOOR BOOKS}

\section{ECHOES OF SPORT}

By The Honble. Mrs. Murray (of Elibank). With Fifteen Illustrations from Photographs. Extra crown 8vo, I68 pp., buckram

\section{5s, net.}

A collection of reminiscences of many glorious days of sport by one of the leading sportswomen of our day. Deer stalking among the wild corries, hunting in the shires, shooting the grouse and capercailzie, fishing on loch and river form some of the subjects of these interesting experiences.

\section{THE KEEPER'S BOOK}

New (Seventh) Edition, completely revised and largely rewritten, with many additional chapters, plans, and 13 illustrations, by $\mathrm{P}$. JEFFREY MACKIE, and various writers, including F. G. Aflalo, Lord Malise Graham, Capt. H. S. Kennedy, Tom Speedy, and P. D. Malloch. Demy 8vo, 488 pp., buckram, 7s. 6d. net.

\section{THE TROU'T WATERS OF ENGLAND}

Being a guide to English trouting streams and reservoirs, with notes on Tackle. By W. M. Gallichan. Decorations and end-papers in colour. Cheaper Edition. Fcap. 8vo, I66 pp., cloth, 28. 6d. net; Wrapper, 1s. net.

\section{IN THE LAND OF THE BEAUTIFUL TROUT}

By A. Tysilio Johnson. With decorations and end-papers in colour. New and Cheaper Edition. Fcap. 8vo. I70 pp., cloth, 28. 6d. net; Wrapper, 18. not.

\section{BIRD LIFE}

Illustrated with over roo of the famous Photographs of Birds and their Nests by Charles ReId, Wishaw. Sm. square, cloth, xo8 pp. 18. net; Wrapper, 6d. net.

\section{THE WILD FLOWERS}

A guide to the commoner wild flowers of the countryside, by $\mathrm{J} . \mathrm{H}$. CrawFord, F.L.S. With Sixteen Illustrations in colour from paintings by Edwin Alexander, A.R.W.S., A.R.S.A. Extra crown 8vo, 228 pp., buckram, 58. net; bound in finest velvet calf, 108. 6d. net.

Second Edition.

Mr. Alexander's illustrations of Wild Flowers are unique and probably the finest ever seen in a nature book.

Complete List of General and Presentation Volumes, post free

T. N. FOULIS, 21 Paternoster Sq., London ; and Edinburgh 




$\overline{\mathrm{M}} 313009$ 
